\title{
THE LATE HOLOCENE HISTORY OF VEGETATION, CLIMATE, FIRE DYNAMICS AND HUMAN IMPACTS IN JAVA AND SOUTHERN KALIMANTAN
}

\author{
Dissertation zur Erlangung des Doktorgrades der \\ Mathematisch-Naturwissenschaftlichen Fakultäten der \\ Georg-August-Universität Göttingen
}

\author{
vorgelegt von \\ M.Sc. \\ Poliakova, Anastasia \\ aus \\ Tschita, Russland
}

Göttingen, September 2015 


\section{Thesis Committee}

Prof. Dr. Hermann Behling

(Dept. Palynology and Climate Dynamics / A.-v.-H. Institute for Plant Sciences, Göttingen)

Prof. Dr. Markus Hauck

(Dept. Plant Ecology and Ecosystem Research/ A.-v.-H. Institute for Plant Sciences, Göttingen)

PD Dr. Dirk Gansert

(Centre of Biodiversity and Sustainable Land UseCentre of Biodiversity and Sustainable Land Use / A.-v.-H. Institute for Plant Sciences, Göttingen)

\section{Additional Members of the Examination Board}

Prof. Dr. Erwin Bergmeier

(Dept. of Vegetation and Phytodiversity Analysis / A.-v.-H. Institute for Plant Sciences, Göttingen)

Prof. Dr. Alexander Schmidt

(Courant Research Centre "Geobiology", University of Göttingen)

Prof. Dr. Dirk Hölscher

(Tropical Silviculture and Forest Ecology, Burckhardt Institute, Göttingen)

PD. Dr. Karin Zonneveld

(Center for Marine Environmental Sciences (MARUM) / University of Bremen; Leibniz Center for Tropical Marine Ecology (ZMT), Bremen) 


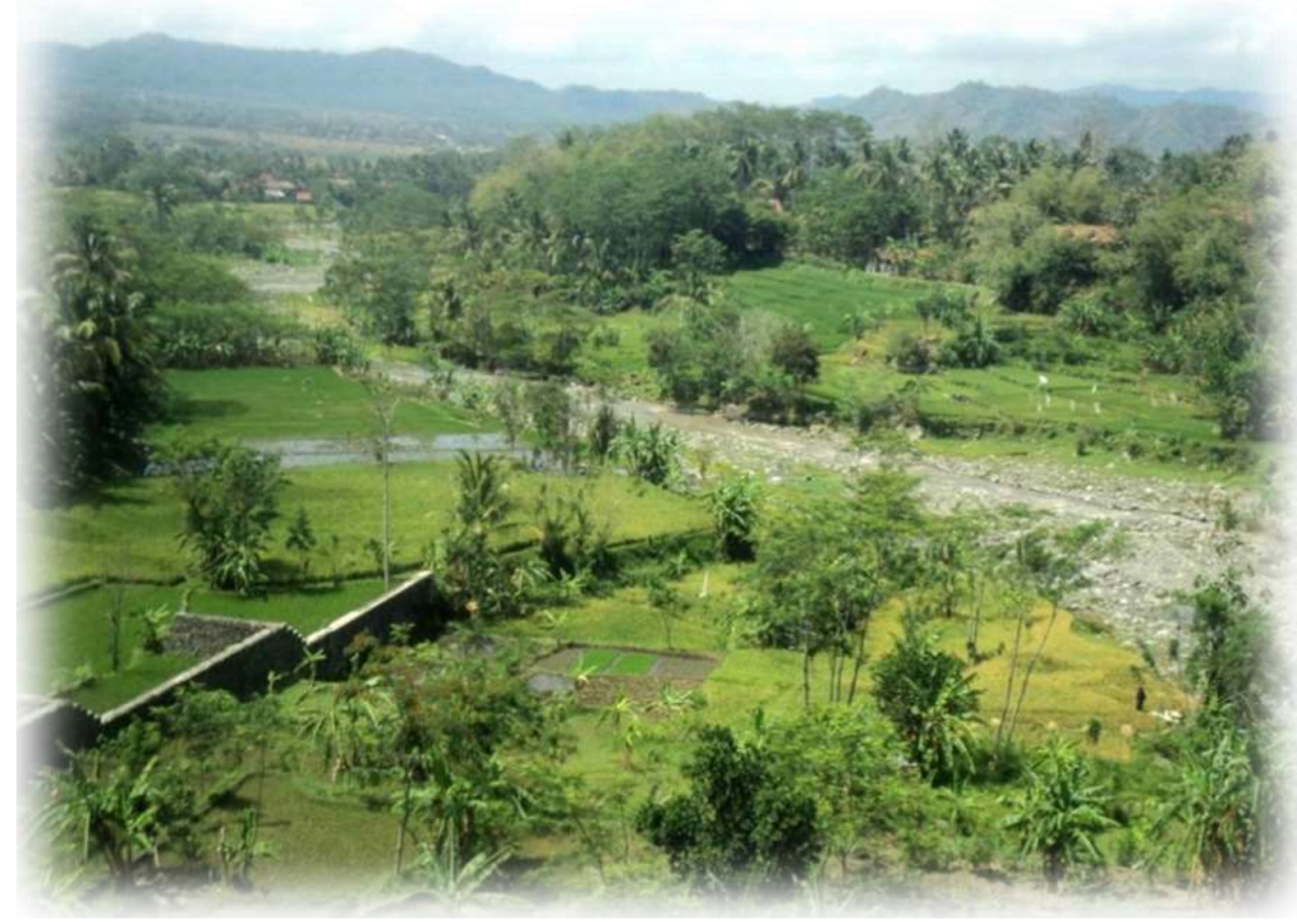

Agricultural landscape in the Central Java Province, Indonesia. October 2012 


\section{Table of Contents}

\begin{tabular}{|c|c|}
\hline LIST OF ACRONYMS & 7 \\
\hline LIST OF TABLES & 8 \\
\hline LIST OF FIGURES & 9 \\
\hline ACKNOWLEGEMENTS & 12 \\
\hline PREFACE & 14 \\
\hline General motivation and objectives of current studies & 14 \\
\hline Structure of the thesis and chapters outline & 15 \\
\hline SUMMARY & 17 \\
\hline ZUSAMMENFASSUNG & 19 \\
\hline REZUME & 21 \\
\hline CHAPTER 1 & 23 \\
\hline Introduction & 23 \\
\hline 1.1. Marine palynology. Pollen transportation and translocation in marine realm & 23 \\
\hline 1.2. Material and research methods & 24 \\
\hline 1.3. Overview of the study area & 28 \\
\hline 1.4. References & 39 \\
\hline CHAPTER 2 & 44 \\
\hline Marine palynology in SE Asia: State of knowledge & 44 \\
\hline 2.1. Studies on fossil pollen & 44 \\
\hline 2.2. Palynological studies of marine surface sediments & 45 \\
\hline 2.3. Studies on dinocysts & 46 \\
\hline 2.4. References & 46 \\
\hline CHAPTER 3 & 49 \\
\hline $\begin{array}{l}\text { Eleven Month High Resolution Pollen and Spore Sedimentation Record off SW Java in the } \\
\text { Indian Ocean }\end{array}$ & 49 \\
\hline Abstract & 50 \\
\hline 3.1. Introduction & 50 \\
\hline 3.2. Environmental settings & 51 \\
\hline 3.3. Material and methods & 54 \\
\hline 3.4. Results & 55 \\
\hline 3.5. Interpretation and discussion & 58 \\
\hline 3.6. Conclusions & 62 \\
\hline 3.7. Acknowledgements & 63 \\
\hline $\begin{array}{l}\text { Appendix A. List of identified pollen and spore types from marinesediment trap } \\
\text { JAM2 }\end{array}$ & 64 \\
\hline Appendix B. Supplementary data & 65 \\
\hline 3.8. References & 65 \\
\hline CHAPTER 4 & 70 \\
\hline $\begin{array}{l}\text { Marine environment, vegetation, and land use changes related to the human impact during } \\
\text { the late Holocene in South Kalimantan and East Java based on pollen and dinoflagellate } \\
\text { cysts }\end{array}$ & 70 \\
\hline Abstract & 71 \\
\hline 4.1. Introduction & 71 \\
\hline 4.2. Regional settings & 72 \\
\hline 4.3. Material and Methods & 74 \\
\hline 4.4. Results & 77 \\
\hline 4.5. Interpretation and discussion & 84 \\
\hline
\end{tabular}




\begin{tabular}{|c|c|}
\hline 4.6. General comparison of the study sites and conclusion & 96 \\
\hline 4.7. Acknowledgements & 97 \\
\hline 4.8. Literature & 97 \\
\hline CHAPTER 5 & 106 \\
\hline $\begin{array}{l}\text { High resolution multi-proxy reconstruction of environmental changes in coastal waters of } \\
\text { the Java Sea, Indonesia, during the late Holocene }\end{array}$ & 106 \\
\hline Abstract & 107 \\
\hline 5.1. Introduction & 107 \\
\hline 5.2. Study site & 108 \\
\hline 5.3. Material and Methods & 109 \\
\hline 5.4. Results & 115 \\
\hline 5.5. Interpretation and Discussion & 120 \\
\hline 5.6. Summary and conclusions & 124 \\
\hline 5.7. Acknowledgements & 125 \\
\hline 5.8. Disclosure statement & 125 \\
\hline 5.9. Supplemental data & 125 \\
\hline 5.10. References & 125 \\
\hline CHAPTER 6 & 131 \\
\hline $\begin{array}{l}\text { Pollen and fern spores recorded in recent and late Holocene marine sediments from the } \\
\text { Indian Ocean and Java Sea in Indonesia }\end{array}$ & 131 \\
\hline Abstract & 132 \\
\hline 6.1. Introduction & 132 \\
\hline 6.2. Modern vegetation as a source for pollen and spores in the Java Sea & 134 \\
\hline 6.3. Material and methods & 136 \\
\hline 6.4. Results and discussion & 139 \\
\hline 6.5. Conclusion & 143 \\
\hline 6.6. Acknowledgements & 144 \\
\hline 6.7. References & 144 \\
\hline CHAPTER 7 & 149 \\
\hline Overall discussion and synthesis & 149 \\
\hline 7.1. Main research outcomes and discussion & 149 \\
\hline 7.2. Uncertainties and open questions & 152 \\
\hline 7.3. Concluding remarks & 154 \\
\hline 7.4. Further perspective & 155 \\
\hline 7.5. References & 155 \\
\hline APPENDIX A & 156 \\
\hline $\begin{array}{l}\text { Complete lists of identified pollen, spores and organic-walled dinocysts types mentioned in } \\
\text { the thesis }\end{array}$ & 156 \\
\hline Appendix A1. Complete list of pollen and spore types mentioned in the thesis & 157 \\
\hline $\begin{array}{l}\text { Appendix A2. Microphotographs of all spore and pollen types mentioned in the } \\
\text { thesis }\end{array}$ & 160 \\
\hline APPENDIX B & 173 \\
\hline Complete list of organic-walled dinocysts types mentioned in the thesis & 175 \\
\hline APPENDIX C & 175 \\
\hline Complete Pollen Records & 176 \\
\hline $\begin{array}{l}\text { Appendix C1. Complete pollen record (\%) of sediment trap JAM-2 showing } \\
\text { percentages of pollen of mangroves, lowland and montane trees, herbs and fern } \\
\text { spore as well as pollen and Pteridophyta sums and pollen accumulation rate (PAR) } \\
\text { under changing monsoon conditions in the Indian Ocean off SW Java. }\end{array}$ & 179 \\
\hline $\begin{array}{l}\text { Appendix C2. Complete pollen record (\%) of the sequence } 1412-19 \text { showing relative } \\
\text { frequencies of pollen and spore types, main vegetation groups, pollen and }\end{array}$ & 182 \\
\hline
\end{tabular}




\begin{tabular}{|l|c|}
\hline microcharcoal concentrations. & \\
\hline $\begin{array}{l}\text { Appendix C3. Complete pollen record (\%) of the sequence 1609-30 showing relative } \\
\text { frequencies of pollen and spore types, main vegetation groups, pollen and } \\
\text { microcharcoal concentrations. }\end{array}$ & 182 \\
\hline APPENDIX D & 185 \\
\hline Core Stratigraphy and Radiocarbon Dating & 185 \\
\hline $\begin{array}{l}\text { Appendix D1. Stratigraphy of the core 1412-19 and calibrated age model (linear } \\
\text { interpolation, cal yr BP vs core depth) based on the radiocarbon dates from Table 1 } \\
\text { (Chapter 2) and the estimated sedimentation rate. The outlet at 71-72 cm is } \\
\text { depicted as a point unconnected to other dating points. }\end{array}$ & 186 \\
\hline $\begin{array}{l}\text { Appendix D2. Stratigraphy of the core 1609-30 and calibrated age model (linear } \\
\text { interpolation, cal yr BP vs core depth) based on the radiocarbon dates from Table 1 } \\
\text { (Chapter 2) and the estimated sedimentation rate. }\end{array}$ & 186 \\
\hline $\begin{array}{l}\text { Appendix D3. Stratigraphy of the core 1612-23 and calibrated age model (linear } \\
\text { interpolation, cal yr BP vs core depth) based on the radiocarbon dates from Table 1 } \\
\text { (Chapter 4) and the estimated sedimentation rate. }\end{array}$ & 186 \\
\hline
\end{tabular}




\section{List of Acronyms}

AD: Anno Domini

AMS: Accelerator Mass Spectrometry

ASPA: Australian Spore and Pollen Atlas

BP: Before Present (1950)

$\mathrm{C}^{14}$ - Radiocarbon, Radioactive

Isotope of Carbon

$\mathrm{CaCO}_{3}$ : Calcium Carbonate

Cal: Calibrated

Chl-a: Chlorophyll-a

$\mathrm{C}_{\text {org: }}$ Organic Carbon

DCA: Defriended Correspondence Analysis

E.G.: Exemplī Grātiā; for example

ECC: Equatorial Counter Current

ENSO: El Niño-Southern Oscillation

FAO: Food and Agriculture Organization of the United Nations

GIS: Geoinformation Systems(s)

HCL: Hydrochloric Acid

HE: Halmahera Eddy

HF: Hydrofluoric Acid

I.E.: Id Est; that is

IOD: Indian Ocean Dipole

IPWP - Indo-Pacific Warm Pool

ITF: Indonesian Throughflow

KSTF: Karimata Strait Throughflow

LC: Leeuwin Current

LDC: Long Distance Component

LG: Luzon Gyre

ME: Mindanao Eddy
MSTF: Makassar Strait Throughflow

$\mathrm{N}$ : North

NEC: North Equatorial Current

NG: Nansha Gyre

NPP: Non-Pollen Palynomorph

$\mathrm{N}_{\text {tot: }}$ :Total Nitrogen Content

NW: Northwest

ODV: Ocean Data View Software, 2014

PA: Procrustes Analysis

PCA: Principal Component Analysis

RBC: Smooth-Walled Round Brown Cysts,

Brigantedinium spp.

RDA: Redundancy Analysis

Rpm: Rounds per Minute

RV: Research Vessel

S: South

SE: Southeast (Asia)

SEC: South Equatorial Current

SJC: Southern Java Current

SSS: Sea Surface Salinity

SST: Sea Surface Temperature

SW: Southwest

TOC: Total Organic Carbon

VOC: Vietnam Offshore Current

WOA: World Ocean Atlas, 2009

W: West

$\operatorname{Yr}(\mathrm{s})$ : Year (Years)

$\delta^{13}$ Corg: Carbon Stable Isotope

$\delta^{15} \mathrm{~N}$ : Nitrogen Stable Isotope 


\section{List of Tables}

Table 1.1. Summarised information on the sites and sediment material studied

Table 3.1. Number of samples and sampling periods of trapped material off SW Java in the tropical SE Indian Ocean. The abbreviations indicate the following: NW - northwest monsoon; non (light-grey shading) - intermonsoon period; SE (dark-grey shading), southeast monsoon.

Table 3.2. Flowering periods of selected taxa in South-East Asia and Australia.

Table 4.1. Radiocarbon dates obtained from the two sediment cores 1609-30 and 1412-19 retrieved from the Java Sea. ${ }^{*}$ The shell dated is considered to be reworked and, therefore, the date was omitted.

Table 5.1. Radiocarbon dates obtained from the sediment core 1612-23.

Table 6.1. $\quad$ Spore and pollen types according to their morphology (after Lang, 1994 with additions). Only identified types are included. 


\section{List of figures}

Fig. 1.1. Age scheme of the marine sediment cores used for the present study. Radiocarbon dating (Stuiver and Polach, 1977) and calibration (CALIB 7, marine 13: Stuiver and Reimer, 1993) considering a reservoir age of $90 \mathrm{yr}$ (Southon et al., 2002).

Fig. 1.2. Marine time-series sediment trap Parflux Mark 7G-21 (A) general view; (B) scheme of the trap mooring; (C) principal scheme of the time-sediment sediment trap, from: http:woodshole.er.usgs.govopen.

Fig. 1.3. Schematic map of the study area. Marine sediment cores that are referred to in the thesis and a sediment trap are shown with red dots.

Fig. 1.4. Annual see surface temperature, SST (A), annual sea surface salinity, SSS (B), and concentrations of the oxygen (C), nitrates (D), phosphates (E), and chlorophyll-a concentration (F) in the surface waters of Java Sea. Environmental data (SST, SSS, oxygen, nitrate and phosphate concentrations) are derived from the World Ocean Atlas (2009); data on chlorophyll-a concentration derived from The Giovanni Ocean Colour Radiometry Portal).

Fig. 1.5. Schematic map showing main forest types in Indonesia (after Stibig, et al., 2002) main oceanic currents and winds in the source area during the NW (A) and SE monsoon (B). Patterns of winds are followed Black (2002) and P. Wang et al. (2000, 2005); directions of currents are modified after Schott and McCreary (2001), Zheng et al. (2006), Fang et al. (2009). The abbreviations stand for the following: ITF, Indonesian Throughflow; ECC, Equatorial Counter Current; KSTF, Karimata Strait Throughflow; LG, Luzon Gyre; MSTF, Makassar Strait Throughflow; NG, Nansha Gyre; VOC, Vietnam Offshore Current.

Fig. 1.6. Vertical zonation of Javanese (based on Stuijts, 1993 and Stuijts et al., 1988) and Kalimantan (based on Whitmore, 1984a and MacKinnon et al., 1997) mountains with the characteristic taxa of vegetation belts.

Fig. 1.7. Tree cover in Indonesian archipelago in comparison with shrub/grass cover, secondary/planted vegetation and burnt vegetation.

Fig. 1.8. Forest cover lost in Indonesia in total, Kalimantan and Java from 2001 and 2013 (A) and comparison between tree cover lost and tree cover gain (data are derived from Margono et al., 2014; http://nfms.dephut.go.id/ipsdh).

Fig. 3.1. Schematic map showing main oceanic currents and winds in the study area during the (A) southern summer (NW monsoon) and (B) southern winter (SE monsoon) with the position of the sediment trap JAM2 off SW Java (dark-grey dot). Wind patterns according to Wyrtki, 1957; Black (2002) and Wang et al. (2000, 2005); directions of currents are modified after Schott, McCreary (2001); Zheng et al. (2006); Fang et al. (2009). The abbreviations stand for the following: ITF, Indonesian Throughflow; HE, Halmahera Eddy; ECC, Equatorial Counter Current; KSTF, Karimata Strait Throughflow; LC, Leeuwin Current; LG, Luzon Gyre; ME, Mindanao Eddy; MSTF, Makassar Strait Throughflow; NEC, North Equatorial Current; NG, Nansha Gyre; SEC, South Equatorial Current; SJC, Southern Java Current; VOC, Vietnam Offshore Current. Dashed arrows show temporal flows.

Fig. 3.2. Main vegetation types of Indonesia. Modified after http://bioval.jrc.ec.europa.eu (Continental Southeast Asia - Forest cover map, 1998-2000 and Insular Southeast Asia - Forest Cover Map, 1998-2000; Stibig and Malingreau, 2003; Stibig et al., 2003, 2004).

Fig. 3.3. Pollen diagram showing percentage of main pollen and spore types under changing monsoon conditions in the Indian Ocean off SW Java.

Fig. 3.4. Pollen diagram showing percentages of pollen of mangroves, lowland and montane trees, herbs and fern spore as well as pollen and Pteridophyta sum and pollen 
accumulation rate (PAR) under changing monsoon conditions in the Indian Ocean off SW Java. The abbreviations indicate the following: NW - northwest monsoon; non (light-grey shading) - intermonsoon period; SE (dark-grey shading), southeast monsoon.

Fig. 4.1. Schematic map of the study area. Position of cores 1412-19 and 1609-30 is shown with red circles. The map has been created using the Ocean Data View software (Schlitzer, 2014).

Fig. 4.2. Pollen diagram for the core 1609-30 showing relative frequencies of selected pollen and spore types, main vegetation groups and concentration. Pollen types of pioneer taxa have striped profiles; pollen types of timber tree taxa have grey profiles.

Fig. 4.3. Dinocyst diagram for the core 1609-30 showing relative frequencies of individual taxa, main groups and cyst concentration.

Fig. 4.4. Pollen diagram for the core 1412-19 showing relative frequencies of selected pollen and spore types, main vegetation groups and concentration. Pollen types of pioneer taxa have striped profiles; pollen types of timber tree taxa have grey profiles.

Fig. 4.5. Dinocyst diagram for the core 1412-19 showing relative frequencies of individual taxa, main groups and cyst concentration.

Fig. 4.6. Extraction from the ordination diagram of the principle component analysis (PCA) for pollen types from (A) core 1412-19 and (B) core 1609-30 (B). Only scores for timber trees pollen and pollen of the pioneer taxa are shown; the whole table of scores can be found in Appendix B. The percentage values on the axes indicate the explained variation.

Fig. 4.7. Extractions from the ordination diagram of the principle component analysis (PCA) for dinocyst types from (A) core 1412-19 and (B) core 1609-30. Only scores for eutrophic dinotypes are shown. The percentage values on the axes indicate the explained variation.

Fig. 4.8. Procrustes analysis errors in two-dimensional ordination space between pollen and dinocysts for the comparison of PCA ordinations of (A) core 1412-19 and (B) core 1609-30. The length of the arrows indicate the magnitude of similarity between paired sites with short arrows suggesting high similarity and long arrows suggesting low similarity.

Fig. 5.1. Study area with main water depths, land orography (delivered from the World Ocean Atlas, 2009) and a position of the study site (marked with a dot). The map was created using the Ocean Data View software (Schlitzer, 2014).

Fig. 5.2. Organic-walled dinocyst diagram showing relative abundances of the individual dinotypes, sums of cosmopolitan, open sea and neritic dinotypes, phototrophic and heterotrophic species, dry bulk concentrations of dinocysts, pollen and fern spores, sedimentation rates and a CONISS cluster-diagram based on total sum of squares.

Fig. 5.3. Light microscope photographs of selected phototrophic taxa found in the sediment sequence 1216-23: 1.- Ataxodinium choane Reid 1974; 2 - Bitectatodinium spongium (Zonneveld 1997) Zonneveld et Jurkschat 1999; 3 - Impagidinium strialatum (Wall 1967) Stover et Evitt 1978; 4 - Impagidinium aculeatum (Wall 1967) Lentin et Williams 1981 ; 5 - Nematosphaeropsis labyrinthus (Ostenfeld 1903) Reid 1974; 6 - Operculodinium centrocarpum Wall et Dale 1966; 7 -Operculodinium israelianum (Rossignol 1962) Wall 1967; 8 - Trinovantedinium applanatum (Bradford 1977) Bujak et Davies 1983; 9 - Tuberculodinium vancampoae (Rossignol 1962) Wall 1967. Scales bars: $20 \mu \mathrm{m}$.

Fig. 5.4. Light microscope photographs of selected phototrophic taxa found in the sediment sequence 1216-23: 1- Spiniferites ramosus (Ehrenberg 1838) Mantell 1854; 2 Spiniferites mirabilis (Rossignol 1964) Sarjeant 1970; 3 - Spiniferites pachydermus (Rossignol 1964) Reid 1974; 4, 5 - Spiniferites spp. G. A. Mantell 1850; 6 Lingulodinium machaerophorum (Deflandre and Cookson 1955) Wall 1967. Scales 
Fig. 5.5. Light microscope photographs of selected heterotrophic taxa found in the sediment sequence 1216-23: 1- Brigantedinium spp. (RBC) Reid 1977 ex Lentin et Williams 1993; 2 - Echinidinium transparantum Zonneveld 1997; 3 - Stelladinium robustum Zonneveld 1997; 4 - Selenopemphix quanta (Bradford 1975) Matsuoka 1985; 5 Votadinium calvum Reid 1977; 6-Selenopemphix nephroides (Benedek 1972) Benedek et Sarjeant 1981. Scales bars: $20 \mu \mathrm{m}$.

Fig. 5.6. Depth-related changes in total nitrogen content $\left(\mathrm{N}_{\text {tot }}\right)$, organic carbon $\left(\mathrm{C}_{\text {org }}\right)$, carbon $\left(\delta^{13} \mathrm{C}_{\text {org }}\right)$ and nitrogen $\left(\delta^{15} \mathrm{~N}\right)$ stable isotope, calcium carbon $\left(\mathrm{CaCO}_{3}\right)$ and opal throughout the core 1612-23.

Fig. 5.7. Results of RDA illustrating dinotypes in relation to biogeochemical environmental variables. Biogeochemical parameters are abbreviated as indicated in text. Dinocyst types are indicated as following: At.choan - Ataxodinium choane, Brig Brigantedinium spp. (RBC), Bt.spong - Bitectatodinium spongium, C.P.kaff - Cyst of Polykrikos kofoidii, C.Pent.dal - cyst of Pentapharsodinium dalei, C.pol.schw - cyst of Polykrikos schwartzii, Ech.gran - Echinidinium granullatum, Ech.trans - Echinidinium transparantum, Ech.zonn - Echinidinium zonnefeldii, Im. Str - Impagidinium strialatum, Im.acul - Impagidinium aculeatum, Im.plc - Impagidinium plicatum, In.sph - Impagidinium sphaericum, Ling.mach - Lingulodinium machaerophorum, Lj.oliv - Lejeunicista olive, Lj.sab - Lejeunecysta sabrina, Nem.lab Nematosphaeropsis labyrinthus, Opp.cent - Operculodinium centrocarpum, Opp.izr Operculodinium israelianum, Opp.spp - Operculodinium spp., Pol.zh Polysphaeridium zoharyi, Q.conc - Quinquecuspis concreta, Sel.nf - Selenopemphix nephroides, Sell.rb - Stelladinium robustum, Sp.mir - Spiniferites mirabilis, Sp.pach Spiniferites pachydermus, Sp.ram - Spiniferites ramosus, Sp.spp - Spiniferites spp., Tr. appl - Trinovantedinium applanatum, Tub.vn - Tuberculodinium vancampoae, Vot.calv - Votadinium calvum.

Fig. 6.1. Schematic map of the study area with distribution patterns of main vegetation types. Marine sediment cores and a sediment trap are shown with red dots. Data on the vegetation distribution are derived from OSGeo website (http://geonetworkopensource.org) and partly from Stibig et al. (2002). 


\section{Acknowledgments}

I would like to express my heartfelt thanks to all those people whose knowledge, support, and encouragement made all this during the last three years worthwhile and possible. Each of you get my kind regards and... this thesis as a result.

First of all, I would like to express my deepest gratitude to my supervisor and a head of the Department of Palynology and Climate Dynamic (Georg-August-University, Albrecht-von-HallerInstitute for Plant Sciences, Göttingen), professor Hermann Behling for his friendly attitude and constant attention at all stages of my research, for the opportunity to work in such a well-equipped institution with its international atmosphere, for a great chance to improve my knowledge in palynology and palaeoecology, to study the vegetation of tropics, to participate in conferences and publish my papers at the international level. My PhD-work in Göttingen has influenced my life a lot, both scientific and non-scientific way, for all this I am indebted to you, Hermann. Ich danke ihnen tausendmal, Professor Behling!

My special thanks go to Dr. Karin A.F. Zonneveld (Center for Marine Environmental Science, MARUM, Bremen) who has opened a wonderful world of Dinoflagellates to me. I thank you for your time, for your incredible individual courses in dinocysts' systematics, morphology and statistics, for your patient explanations, for critical reviewing my papers and being my perfect consulter and co-author. Dank u zeer dierbaar, Karin!

I would like to thank the Bundesministerium für Bildung und Forschung (BMBF) and a GermanIndonesian bilateral programme "Science for the Protection of Indonesian Coastal Marine Ecosystems (SPICE III - CAFINDO, BMBF grant no. 03F0645C)" for the funding of this research. I thank the members of my promotion committee for spending time on evaluating my thesis and for providing useful comments and suggestion.

I thank Dr. Tim Rixen, Dr. Dirk Hebbeln, Dr. Mahyar Mohtadi and MSc. Cornelia Kwiatkowski (MARUM) as well as Dr. Claudia Schultz, Dr. Tim Jennerjahn, Dr. Ricardo De Pol-Holz and Dr. Lucia Harbeck (the Leibniz Center for Tropical Marine Ecology, ZMT), Bremen. I thank all colleagues from our department.

My special and deepest acknowledgements goes to Dr. Tatiana Yu. Zengina (Moscow State University, department of Geography) who has introduced me into the GIS analysis. I still use your practical advices, despite they were given to me almost ten years ago. They are not getting oldfashioned unlike the software we use. Я от души благодарю Вас, Татьяна Юрьевна!

My thanks go across the equator, to the University of Purwokerto (Universitas Jenderal Soedirman, Indonesia). Dr. Husein Sastranegara is acknowledged for his support in logistics during my field work in Indonesia. Dr. Haryadi Permana (Earth Dynamics and Geological Disaster Division Research Center 
for Geotechnology, Bandung) is acknowledged for providing me marine sediment samples. I owe my thanks to the drivers Arul and Mohammed who provided me transport during my field work. I thank a lot the boat driver Sukko for his unique skills in going with piruga through the shallow and narrow channels in mangrove area. Matur nuwun Sukko! I say many thanks to my field assistants Usdianto and Misika Aiam for their help in coring and taking sediment surface samples. Christina Ani is thanked for her help with translation of the Summary into Indonesian. Terima kasih Christina, Usdi dan Aiam!

I am appreciated laboratory support provided by Uta Nüsse-Hahne, Cornelia Roth, Mirijam Kiggen and Johanna Brockhaus. Mirijam Kiggen is additionally thanked for her help with the preparation of the pollen photos for the atlas and for translation of our annual reports as well as the Summary of this thesis into German. I express my gratitude to the crew of the RV SONNE, cruise SO-184, 20022003, who helped to collect sediment trap material. I cordially thank Dr. Jörg Christiansen for his computer assistance, software providing and for being always there to answer lots of my questions and to help with German official letters. I appreciate the time and support of Dr. Felix Bitman as well as his introduction into the identification of cultural plant remains.

Such a nice and productive work in the Herbarium would be not possible without the support of Dr. Marc Appelhans. Dr. Sonia Fontana gets my regards for having spent time teaching me the macroremains analysis and reading through the text of my pollen atlas before its publication. Dr. Analia Diaz gets my thanks for the introduction into ostracod analysis. Dr. Liang-Chi Wang is amicably thanked for his tutorials on the analysis of diatoms. Prof. Dr. Hanns Hubert Leuschner gets my deep and sincere gratitude for his classes in dendrochronology and unforgettable fieldwork at the Gifhorner Moor. It was always a great fun and pleasure to work with you, Hubertus!

I pay salute to Dr. Dmitry A. Prokhorov, my coach, mountaineering partner and an experienced geologist, for his nice discussions during my writing this thesis as well as for his 15-year long sharing a climbing rope with me. Amicable hospitality of Nadiya Rumyantseva and her family during my stay in St. Petersburg and of Katharina, Ingrid and Peter Berg drying my work in Bremen are deeply acknowledged. I say '感 謝!' to Pan, Min, Li, Fang and Ye. I say 'Хвала!' to Miliza and Jovan. I say 'Dziękuję!' to Vera and Katarzina. I say 'Köszönöm!' to Hainalka.

Last but not least, I would like to thank the most important people in my life: Irina, Alexander, Olga, Dmitry, Nina, Igor and Lev. Thank you for having accepted my decision to work abroad and supported it. Thank you for being with me at all time. Your patience and unflagging support, your friendship and your fidelity are the most important and the only constant things that I possess in this bright and unpredictable life. Спасибо вам, друзья мои! 


\section{Preface}

\section{General motivation and the objectives of current studies}

This work was aimed to reconstruct the past vegetation patterns and environment conditions on land and in the marine realm with regard to their responses to climate, fire and land use changes in Java and Southern Kalimantan (Indonesia). As natural vegetation communities of the study area has experienced some hundred years of human activity, main focus of current investigation was set on the reflection of human related factors controlling changes in the region. Two sites were chosen for comparison: heavily populated Java with some 5000-7000 yr long (Whitmore, 1984a) history of the human activity and Kalimantan with its relatively thin population and much less changed vegetation. The principal question of our research was: How had all mentioned changes been reflected by the vegetation in Java and Kalimantan and by coastal dinocysts communities in the Java Sea during the Late Holocene? In order to respond this question, the following hypotheses were approached:

(1) Different vegetation patterns on Java and Kalimantan are well reflected in pollen in the sediments.

(2) Natural environmental changes have nowadays a smaller impact on ecosystems then anthropogenic environmental changes.

(3) Changes in land use (specifically changes in vegetation) increased during the Late Holocene and particularly during the Anthropocene.

(4) Environmental changes are reflected both in pollen/spores and dinoflagellates assemblages.

(5) Anthropogenic environmental changes give the stronger signal from the island of Java then from the island of Kalimantan.

Brief description of the content of present studies is provided below. 


\section{Structure of the thesis and chapters outline}

This thesis consists of seven chapters prefaced by the synopsis given in English (Summary), German (Zusammenfassung) and Indonesian (Rezume) languages that briefly describe principal research questions, work steps and the main outcomes. The first chapter (Chapter 1) gives an introduction into the subject of marine palynology, describes material and research methods and provides an overview of the study area.

In Chapter 2, the state-of-the-art of marine palynology in SE Asia is addressed and a scholar retrospective is given in terms of pollen and dinoflagellate cyst studies. Additionally, modern investigations are observed.

Next four chapters (Chapters 3-6) build a main part of this thesis and are based on the synthesis of the following manuscripts. Chapter 3 (manuscript one) describes a pilot study on the abundance and taxa composition of modern pollen and spores collected by the sediment trap in the Indian Ocean off SW Java. It discusses factors, which control deposition of the settling particles, and compares pollen assemblages collected under different monsoon conditions over one year. This chapter gives information on the pollen transport required for further interpretation of marine fossil pollen records.

In Chapter 4 (manuscript two), outcome of the organic-walled dinoflagellate cysts and pollen assemblages in marine sediments is presented. The study based on the comparison of two marine cores from the Java Sea off S Kalimantan (Jelai River mouth) and off NE Java (Solo River mouth). This chapter describes the last ca $3500 \mathrm{yr}$ of past vegetation changes and peculiarities of environment dynamics in the marine realm in high resolution, allowing detailed reconstruction of the vegetation/sea environment response to the human-induced environmental changes.

Chapter 5 (manuscript three) discusses results of the multiproxy study of a marine sediment core from the mouth of Pembuang River (SE Kalimantan) and presents outcomes from the dinocyst and geochemical sediment analysis. History of the environmental changes between ca 2850 and $990 \mathrm{cal}$ yr BP in the Java Sea is presented.

Chapter 6 (manuscript four) deals with the pollen diversity in marine sediments. It describes the spectra of fossil pollen from the Java Sea and the spectra of modern pollen from one-year sediment trap deployed in the Indian Ocean off SW Java. In this chapter, we provide a brief analysis of the 
pollen taxa list and support it with the light microscopic photos of pollen and spores at different focal levels.

In Chapter $\mathbf{7}$ the most important outcomes of this research are synthesized, response to the research hypotheses is given and overall conclusions are drawn. Furthermore, the issue of open questions is addressed and finally, some perspectives for marine palaeoecological research in Indonesia are envisioned.

The thesis contains Appendix, where complete lists and photographs of all identified pollen, spores (Appendix A) and organic-walled dinocysts types (Appendix B) are presented. Appendix C presents full pollen, spore and microcharcoal records that are referred to in the text, and in Appendix D stratigraphy of the four marine sediment cores relevant to this study and radiocarbon dating is provided. 


\section{Summary}

Detailed analysis of past environmental, climate and land use history in the Indonesian region is essential to obtain better understanding of human-environment relationships and to prevent uncertainties in future development of the region. Indonesia is one of the world biodiversity hotspots and at the same time it is one of the most heavily populated areas of the planet. Over historical time, the influence of the human activity in the region became more and more intensive. To assess human contribution to the environment change, this project (SPICE III - CAFINDO, subproject 5) was established.

Our work was focused on reconstruction of the past vegetation patterns, environment changes and human-environment interactions as they are reflected in marine sediments of Indonesian waters. Two types of independent proxies were taken for this study: pollen, that originate from land and give diverse information on the vegetation and land use dynamics, and organic-walled dinocysts, that originate from marine environment and reflect changes of both quantitative (e.g. SST, SSS) and qualitative (e.g. trophic state in terms of main macroelements and dissolved water oxygen) water parameters. Moreover, microcharcoal was studied to get insight into the fires history in the region and to obtain additional support for interpretation of pollen and dinocyst data.

Two sites were chosen for comparison: the first, heavily populated Java with its long history of the human activity resulted in widespread agricultural landscapes, and the second, less densely population South Kalimantan less changed by human activity and still, at least partly, barring natural primary vegetation.

Marine palynology as a method requires close attention to the interpretation of data. Factors controlling pollen deposition are of particular importance, especially for the areas with the strong influence of wind and marine currents like the Indonesian region, where the whole climate system is driven mostly by the monsoon reversal. To get some ideas of the sediment transportation in the region, we studied and discussed in detail the differences in pollen assemblages collected under different monsoon conditions as well as during intermonsoon time. Abundance and taxa composition of modern pollen and spores collected by the sediment trap in the Indian Ocean off SW Java became an object of our first manuscript. The results were used in the further interpretation of marine fossil pollen records.

History of the land use intensifications and vegetation change over the last ca $3500 \mathrm{yr}$ revealed from dinoflagellate cysts and pollen assemblages in marine sediments are presented in the second and the third papers. The studies are based on the comparison of two marine cores from the Java Sea off West Kalimantan (Jelai River mouth) and North-East Java (Solo River mouth). In the third manuscript, these records are compared to the more offshore sediment core taken from the mouth of the River 
Pembuang. This study discussed the results of biogeochemical and dinocyst analysis in terms of palaeoecology and palaeoenvironment.

The next study gave us some additional understanding of the pollen flora diversity in the region and how adjacent vegetation is reflected by the diversity of pollen and spores. The fifth manuscript deals with the pollen diversity in marine sediment cores from the Indonesian region. It summarizes our knowledge obtained during the work on four sediment cores from the Java Sea and from the Indian Ocean sediment trap study. In a form of pollen atlas, we provide a list of the all registered pollen taxa and supply it with the microphotographs at different focal levels. The overall result of this work will contribute to the knowledge on the ecosystem dynamics and natural history of the Indonesian region and may help for future detailed palaeoecological and palaeclimatological investigation in the area. 


\section{Zusammenfassung}

Die detaillierte Analyse der Umwelt-, Klima- und Landnutzungsgeschichte in der indonesischen Region ist unumgänglich, um ein besseres Verständnis der Beziehungen zwischen Mensch und Umwelt zu erlangen und desweiteren Ungewissheiten in der zukünftigen Entwicklung der Region vorzubeugen. Indonesien ist einer der Biodiverstitäts-Hotspots und zugleich eines der bevölkerungsreichten Gebiete dieser Erde. Seit historischen Zeiten wurde der Einfluss der menschlichen Aktivität in dieser Region immer intensiver. Daher wurde dieses Projekt ins Leben gerufen, um den Beitrag des Menschen zu den Veränderungen der Umwelt einschätzen zu können.

Unsere Arbeit konzentrierte sich auf die Rekonstruktion vergangener Vegetationsmuster, Umweltveränderungen und Wechselwirkungen zwischen Mensch und Umwelt, so wie sie sich im marinen Bodensediment der Gewässer Indonesiens wiederspiegeln. Es wurden zwei unabhängige Vertreter für diese Studie verwendet: Pollen, die vom Land stammen und unterschiedlichste Informationen über die Vegetation und die Dynamik der Landnutzung liefern und Dinozysten mit organischer Wandung, die aus mariner Umwelt stammen und den Wandel sowohl der quantitativen (z. B. SST, SSS) als auch der qualitativen (z. B. trophischer Zustand, hinsichtlich der Hauptmakroelemente und in Wasser gelösten Sauerstoffs) Wasserparameter wiederspiegeln. Zudem wurde Mikroholzkohle untersucht, um Erkenntnisse über die Brandhistorie in der Region zu erlangen und zusätzlich Unterstützung zur Interpretation der Pollen- und Dinozystendaten zu erhalten.

Zwei Untersuchungsgebiete wurden zum Vergleich ausgewählt: zum Einen das bevölkerungsreiche Java, dessen Landschaft, resultierend aus seiner langen Geschichte menschlicher Aktivität, durch Agrikultur geprägt ist, und zum Anderen das dünner besiedelte Süd-Kalimantan, das durch menschliche Tätigkeiten weniger verändert wurde und nach wie vor die natürliche Primärvegetation beheimatet.

Marine Palynologie als Untersuchungsmethode erfordert besondere Aufmerksamkeit bei der Dateninterpretation. Dabei sind Faktoren, die die Pollenablagerung kontrollieren, wie starker Wind oder Meeresströmungen, von besonderer Bedeutung. Dies ist bei Gebieten, wie Indonesien, wo das gesamte Klimasystem durch den wiederkehrenden Monsun bestimmt wird, besonders zu beachten. Um Einblick in den Sedimenttransport in der Region zu erlangen, wurden die Unterschiede der Pollenansammlungen, die unter verschiedenen Monsunbedingungen, sowie in der Zwischenmonsum-Periode gesammelt wurden, untersucht und diskutiert.

Die Zusammensetzung und Abundanz der Taxa der modernen Pollen und Sporen, die durch eine Sedimentfalle im indischen Ozean südwestlich von Java gesammelt wurden, war Thema unseres ersten Manuskriptes. Die Ergebnisse wurden für die weitere Interpretation mariner fossiler Pollenaufzeichnungen verwendet. 
Die Geschiche der Landnutzungsintensivierung und des Vegetationswandels über die vergangenen ca. 3500 Jahre, die durch die Dinoflagellatenzysten und Pollenansammlungen in marinen Sedimenten aufgezeigt wurden, werden im zweiten und dritten Paper vorgestellt. Diese Studien basieren auf dem Vergleich zweier mariner Bohrkerne aus der Javasee bei West-Kalimantan (Fluss Jelai) und NordostJava (Fluss Solo). Im dritten Manuskript werden diese Aufzeichnungen mit einem Sedimentbohrkern aus der Mündung des Pembuang Flussen verglichen, der küstenferner entnommen wurde. Diese Studie diskutierte die Ergebnisse der geochemischen Analyse der Dinozysten hinsichtlich der Paläoökologie und der Paläoumwelt.

Die nächste Studie gewährte zusätzlichen Einblick in die Pollenflora und Vegetationsdiversität der Region und wie diese sich in der Diversität der Pollen und Sporen wiederspiegeln. Das fünfte Manuskript beschäftigt sich mit der Pollendiversität mariner Bohrkerne aus der indonesischen Region. In diesem werden die Erkenntnisse, die während der Arbeit mit den Sedimentbohrkernen aus dem Javasee und der Sedimentfallenstudie aus dem Indischen Ozean erworben wurden, zusammengefasst.

In Form eines Pollenatlas, wird eine detaillierte Analyse der Liste der Pollentaxa vorgestellt, die mit Mikrophotographien verschiedener Ebenen ergänzt wurde. Das Gesamtergebnis dieser Arbeit trägt zu den Erkenntnissen über die Dynamiken des Ökosystems und der Naturgeschichte der indonesischen Region bei und kann bei zukünftigen detaillierten paläoökologischen und paläoklimatischen Untersuchungen behilflich sein. 


\section{Rezume}

Analisa yang terperinci mengenai lingkungan di masa lalu, iklim dan sejarah penggunaaan lahan di wilayah Indonesia sangat penting untuk memperoleh pemahaman yang lebih baik mengenai hubungan manusia-lingkungan dan untuk mencegah ketidakpastian perkembangan wilayah tersebut di masa depan. Indonesia merupakan salah satu wilayah yang memiliki keanekaragaman terbesar, dan pada saat yang bersamaan juga merupakan salah satu Negara yang mempunyai jumlah penduduk terpadat di dunia. Seiring dengan sejarah, pengaruh dari aktivitas manusia pada suatu daerah menjadi semakin kuat. Penelitian ini dilakukan untuk mengakses peranan manusia terhadap perubahan lingkungan.

Penelitian kami difokuskan pada rekonstruksi pola vegetasi di masa lampau, perubahan lingkungan dan interaksi antara manusia dan lingkungan yang tercermin dalam sedimen laut di perairan Indonesia. Dua macam pendekatan yang digunakan dalam studi ini adalah: polen (serbuik sari), yang berasal dari darat dan diharapkan bisa memberikan informasi yang beragam tentang vegetasi dan dinamika penggunaan lahan, dan organic dinoflagelata yang berasal dari lingkungan laut dan merefleksikan perubahan parameter air secara kuantitatif (misal. SST, SSS) dan kualitatif (mis: kondisi tropic dilihat dari segi makro-elemen utama dan oksigen terlarut dalam air). Selain itu, arang mikro dipelajari untuk mendapatkan data mengenai sejarah kebakaran di wilayah tersebut dan untuk memperoleh data tambahan untuk interpretasi polen dan data dinoflagelata.

Penelitian dilakukan di dua situs sebagai perbandingan: pertama, di wilayah Jawa yang padat penduduk dengan sejarah panjang dari dampak aktivitas manusia yang menghasilkan lanskap pertanian yang luas, dan yang kedua, di wilayah Kalimantan Selatan dengan kepadatan penduduk yang tidak terlalu tinggi dan tidak banyak perubahan akibat pengaruh aktivitas manusia dan masih merupakan vegetasi alami.

Metode yang digunakan, palinologi laut memerlukan perhatian khusus dalam interpretasi data. Faktor pengendapan polen adalah sangat penting, terutama untuk daerah-daerah dengan pengaruh kuat dari angin dan arus laut seperti wilayah Indonesia dimana sistem iklim secara keseluruhan didorong sebagian oleh pergantian musim.

Untuk mendapatkan beberapa pemikiran mengenai transportasi sedimen di wilayah ini, kami mempelajari dan membahas secara rinci perbedaan jumlah polen yang dikumpulkan pada kondisi musim hujan yang berbeda serta selama waktu perpindahan musim. Subyek manuskrip pertama kami adalah kemelimpahan dan komposisi taksa modern polen dan spora yang didapat dari sedimen yang terakumulasi di Samudera India sebelah barat daya Jawa. Hasil yang diperoleh digunakan untuk interpretasi lebih lanjut dari fosil polen laut. 
Sejarah intensifikasi penggunaan lahan dan perubahan vegetasi lebih dari 3500 tahun yang lalu yang diperoleh dari dinoflagelata dan kumpullan polen dari sedimen laut dipresentasikan dalam jurnal yang kedua. Studi ini didasarkan pada perbandingan dua core laut dari lepas Laut Jawa dekat Kalimantan Barat (Sungai Jelai) and bagian timur laut Jawa (Sungai/Bengavan Solo). Pada manuskrip yang ketiga, hasil ini diperbandingkan dengan sedimen core dari lepas pantai yang diambil dari bagian hulu sungai Pembuang. Studi ini membahas mengenai hasil analisa geokimia dan analisa dinoflagelata dalam cakupan paleoekologi dan paleoenvironment.

Manuskrip kelima membahas tentang keragaman polen dalam core sedimen laut dari wilayah Indonesia. Studi ini merangkum pengetahuan yang diperoleh selama meneliti core sedimen dari Laut Jawa dan dari studi perangkap sedimen di Samudera Hindia. Dalam bentuk atlas polen, kami memberikan hasil analisis secara rinci dari daftar taksa polen dan dilengkapi dengan foto mikro pada tingkat fokus yang berbeda. Hasil keseluruhan dari penelitian ini akan memberikan kontribusi pada pengetahuan tentang dinamika ekosistem dan sejarah alam di wilayah Indonesia dan dapat membantu investigasi paleoekologi dan paleo-iklim di masa depan secara lebih rinci. 


\section{CHAPTER 1}

\section{Introduction}

\subsection{Marine palynology. Pollen transportation and translocation in marine realm}

Pollen analyses of marine sediments contributes to reconstructions of the vegetation and climate, particularly in regions where long continuous terrestrial records are scarce or problematic (e.g. Sánchez Goñi et al., 1999; Mudie et al., 2002; Heusser and Oppo, 2003; Moss and Kershaw, 2007). First, because the vegetation patterns can well reflect rapid or abrupt climate change events, rather than showing a lagged response as had been widely assumed previously (Harrison and Sánchez Goñi, 2010). Second, due to the fact that pollen signals in marine records may directly correlate with terrestrial sequences and therefore can provide a basis for transferring marine age-models directly to terrestrial records (Hope et al., 2004; Ryan et al., 2012) and can help to establish a correlation of the changes in marine and terrestrial realm.

Additionally, marine palynological records, unlike terrestrial ones, provide broad regional pictures of vegetation on adjacent landmasses, often collecting pollen from a number of different biomes. They are suitable for the investigation of large shifts in vegetation over long periods, while pollen data from terrestrial deposits give much more detailed information of local or regional vegetation patterns (Dupont, 1999).

Marine pollen diagrams, however, cover often more than one climatic cycle that makes them not always suitable for tracing short-scale climatically induced vegetation change. Careful interpretation of this kind of diagrams places emphasis on transport and sedimentation processes, as these have a strong impact on the results (e.g. Sun, 2002). In the interpretation of pollen data, several aspects must be taken into account: these include source of production of pollen, its transport to the sea and through the water column, displacement by ocean currents, sedimentation processes, fossilization and accumulation in the sediment. Production of pollen grains varies strongly between different species. After pollen and spores reach the sediments, they still can be displaced by sedimentological processes such as bioturbation or sediment movement. Embedded within very slowly accumulating sediments at great water depths, pollen and spores may decay if bottom waters over the site are rich in oxygen and therefore corrosive, or the pollen and spore content may become enriched by the dissolution of calcium out of the sediment (Keil et al., 1994). 
The distribution of many pollen types in the modern marine surface sediments reflects the average course of the trajectory of the major wind belts (Hooghiemstra et al., 1986). Transport of pollen and spores from their source areas to the marine sediments involves several steps. After pollen grains are released by the plants they disperse into the air and are transported by winds, or the grains fall into a lake or a river and are then carried by the river into the ocean. Aeolian transport of pollen and spores predominates in deep-sea sediments located far from the coast and along arid areas with no or small river discharge into the ocean (Heusser and Morley, 1985; Hooghiemstra et al., 1986). In contrast to desert margins, fluvial transport of pollen and spores is high in the humid tropical areas. The role of fluvial transport has been shown by an increased pollen concentration in sediments sampled from the vicinity of river mouths (Muller, 1959; Heusser and Balsam, 1977; Davey and Rogers 1975; Heusser, 1988; Bengo, 1997).

Pollen that has eventually got into the upper layers of the ocean has to be transported down through the water column to the sea floor. Pollen grains are too small and too light to have an effective sink velocity by themselves. However, pollen is caught in larger aggregates - in faecal pellets or large filamental aggregates - that can have sink velocities of $100 \mathrm{~m}$ per day or more (Schrader, 1971; Silver et al., 1978; Honjo, 1980; Wefer, 1991, 1993; Wefer and Fischer 1993). The transport through the water column is more efficient in areas with a high marine surface productivity where the incorporation of palynomorphs in the food chain is enhanced (Ratmeyer et al., 1999). The increased sink velocity reduces drifting by ocean currents. However, along continental slopes, strong boundary currents may displace pollen and spores (Heusser and Balsam, 1985; Dupont and Agwu, 1991).

The importance of transport processes from the continent into the ocean varies from region to region (Dupont, 1999). Palynological studies on modern sediments of continental shelves reflect the influence of both river input and sorting of particles, whereby the sedimentation of pollen and spores can be compared to that of the medium to fine silt fraction, because of their size and density (Rossignol, 1961; Davey, 1971). Because pollen grains from marine sediments are typically transported over long distances, the evaluation of transport agents is always part of the interpretation of marine pollen diagrams (Dupont, 1999). The marine record also provides valuable chronological control for the terrestrial record (Hope et al., 2004). Morover, pollen grains can be used as tracers for the origin of organic matter (Wagner and Dupont, 1999).

\subsection{Material and research methods}

This study is based on the analysis of four marine sediment cores (Table 1.1; Fig 1.1) taken from the Java Sea during the scientific cruises of the RV “Baruna Jaya” and unknown RV in 1995-1998 off South 
Kalimantan (Jelai and Pembuang rivers) and off North-East Java (Solo River). The age schemes of the marine sediment cores are presented in the Fig. 1.1.

Table 1.1. Summarized information on the sites and sediment material studied.

\begin{tabular}{|c|c|c|c|c|c|c|}
\hline & $1412-19$ & $1612-23$ & $1612-26$ & $1609-30$ & JAM-2 \\
\hline \multicolumn{2}{|c|}{ Type of material } & Sediment core & Sediment core & Sediment core & Sediment core & $\begin{array}{l}\text { Sediment } \\
\text { trap }\end{array}$ \\
\hline \multicolumn{2}{|c|}{ Core site } & $\begin{array}{c}\text { Off Jelai River, } \\
\text { SW } \\
\text { Kalimantan; } \\
\text { Java Sea }\end{array}$ & $\begin{array}{c}\text { Off Pembuang } \\
\text { River, } \\
\text { S Kalimantan; } \\
\text { Java Sea }\end{array}$ & $\begin{array}{c}\text { Off Pembuang } \\
\text { River, } \\
\text { S Kalimantan; } \\
\text { Java Sea }\end{array}$ & $\begin{array}{c}\text { Off river Solo, } \\
\text { E Java; Java Sea }\end{array}$ & $\begin{array}{c}\text { off SW } \\
\text { Java; } \\
\text { SE Indian } \\
\text { Ocean } \\
\end{array}$ \\
\hline \multirow[t]{2}{*}{$\begin{array}{c}\text { Core } \\
\text { position }\end{array}$} & Latitude & $\mathrm{S}^{\circ} 15^{\prime} 28.8^{\prime \prime}$ & $\mathrm{S}^{\circ} 35^{\prime} 21.84^{\prime \prime}$ & $\mathrm{S}^{\circ} 47^{\prime} 39.48^{\prime \prime}$ & $\mathrm{S6}^{\circ} 29^{\prime} 49.729^{\prime \prime}$ & $\begin{array}{c}\mathrm{S} 08^{\circ} 17^{\prime} \\
30^{\prime \prime}\end{array}$ \\
\hline & Longitude & $\begin{array}{c}\mathrm{E} 110^{\circ} 38^{\prime} \\
59.399^{\prime \prime}\end{array}$ & $\begin{array}{c}\mathrm{E} 112^{\circ} 44^{\prime} \\
13.56^{\prime \prime}\end{array}$ & $\begin{array}{c}\mathrm{E} 112^{\circ} 34^{\prime} \\
6.96^{\prime \prime}\end{array}$ & $\begin{array}{c}\mathrm{E} 112^{\circ} 28^{\prime} \\
31.328^{\prime \prime}\end{array}$ & $\begin{array}{c}\mathrm{E} 108^{\circ} 02^{\prime} \\
00^{\prime \prime}\end{array}$ \\
\hline \multicolumn{2}{|c|}{ Water depth, m } & 9.7 & 20 & 56,3 & 50 & 2200 \\
\hline \multicolumn{2}{|c|}{ Core length, cm } & 91.5 & 134 & 100 & 96 & ----------- \\
\hline \multicolumn{2}{|c|}{ Year(s) of collection } & 1998 & 1995 & 1998 & 1995 & 2001-2002 \\
\hline \multicolumn{2}{|c|}{$\begin{array}{c}\text { Approximate age, cal } \\
\text { yr BP }\end{array}$} & 1200 & 2850 & 6500 & 3600 & modern \\
\hline \multicolumn{2}{|c|}{ Proxies studied } & $\begin{array}{c}\text { Pollen, } \\
\text { dinocysts, } \\
\text { microcharcoal }\end{array}$ & $\begin{array}{c}\text { Pollen, } \\
\text { dinocysts, } \\
\text { microcharcoal }\end{array}$ & $\begin{array}{c}\text { Pollen, } \\
\text { dinocysts }\end{array}$ & $\begin{array}{c}\text { Dinocysts, } \\
\text { biogeochemical } \\
\text { parameters }\end{array}$ & Pollen \\
\hline \multicolumn{2}{|c|}{ Chapter } & $4,6,7$ & $5,6,7$ & 6,7 & $4,6,7$ & 3,7 \\
\hline
\end{tabular}

1412-19

Age, yr BP

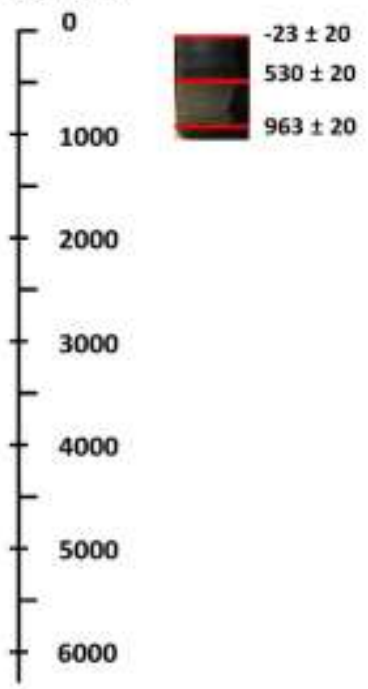

$1609 \cdot 23$

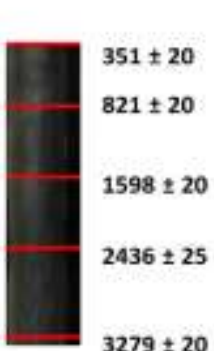

1609-30

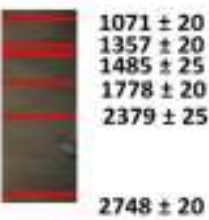

$1609-26$

$1874 \pm 20$

$2332 \pm 20$

$2748 \pm 20$
Fig. 1.1. Age scheme of the marine sediment cores used for the present study. Radiocarbon dating (Stuiver and Polach, 1977) and calibration (CALIB 7, marine 13: Stuiver and Reimer, 1993) considering a reservoir age of $90 \mathrm{yr}$ (Southon et al., 2002). 
A

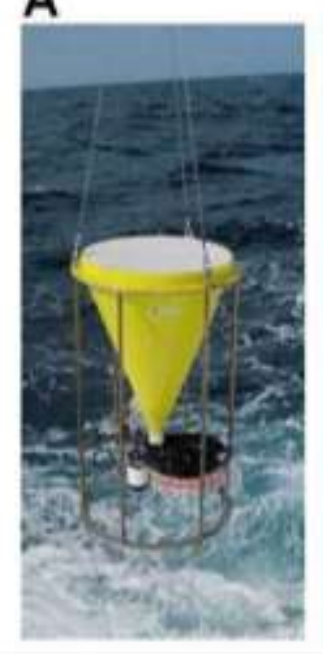

B

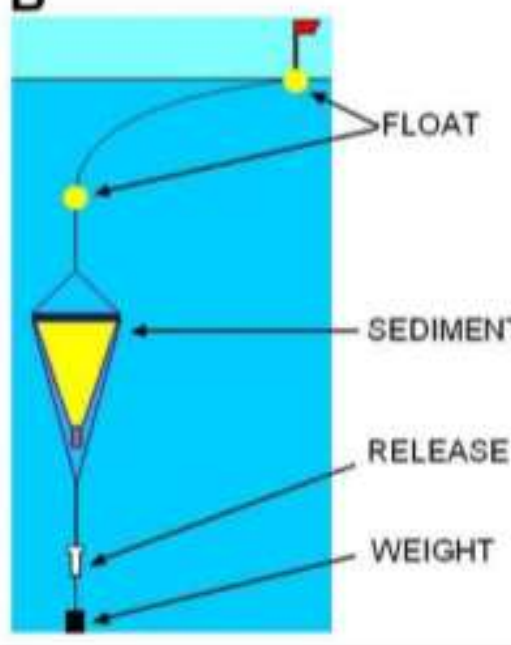

C

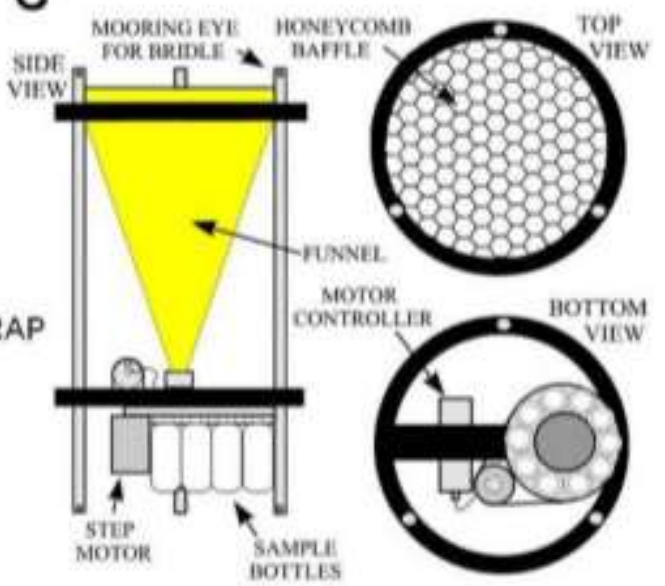

TIME-SERIES SEDIMENT TRAP

Fig. 1.2. Marine time-series sediment trap Parflux Mark 7G-21 (A) general view, from http://www.mbari.org/expeditions/Smith2011/logbook/day4.htm; (B) scheme of the trap mooring, slightly modified after: https://depts.washington.edu/soundcit/about/oceanographic-equipment/sediment-trapschematic; (C) principal scheme of the time-series sediment trap, from: Gallery of common sediment sampling devices, http://woodshole.er.usgs.gov/openfile/of2005-1001/htmldocs/sediment_traps.

Besides, in the second chapter was used the material collected with help of the sediment trap JAM-2 that was moored in the Indian Ocean off SW Java (scheme of trap is given above, see Fig. 1.2) between December 2001 and November 2002 and collected in 2005 during the cruise SO-184, PABESIA, of the research vessel SONNE. Trap mooring water depth was about $2200 \mathrm{~m}$; sampling intervals were 16 days each.

\subsubsection{Laboratory methods}

After subsampling the core material, $3 \mathrm{~g}$ of each sample, was dried overnight at $60^{\circ} \mathrm{C}$ and afterwards weighted to determine the dry bulk density. The material was brought into suspension in distillate water and sieved over a 100-150 $\mu \mathrm{m}$ sieve. In order to remove carbonate, cold hydrochloric acid (HCL $10 \%)$ was applied in amounts depending on the intensity of the reaction. To determine concentration and/or accumulation rate, one Lycopodium clavatum tablet with known number of spores $(20,848 \pm$ 1546) was added to each sample (Stockmarr, 1971). At the next step, hydrofluoric acid (HF 72\%) was added to the washed and centrifuged $(5 \mathrm{~min}, 3200 \mathrm{rpm}$ ) samples for one day in order to remove silicate.

After decantation and washing ( $\mathrm{X} 2$ times) with distillate water, the residue was centrifuged again and transferred to $1.5 \mathrm{ml}$ Eppendorf tubes. The fraction smaller than $10 \mu \mathrm{l}$ were removed sieving over a nylon filter. In order to avoid damage to the dinocysts no acetolysis and other oxidation treatments 
was applied. The material was embedded in glycerin gelatin and isolated from air by transparent nail polish. Pollen, spores and dinocysts were counted under a light microscope (Zeiss Axiostar Plus) at X400 and X1000 magnification. In case of the core material, counting kept up to 200 identified pollen grains and 100 dinocysts, relative abundance of taxa were calculated on the basis of the total sum of pollen grains and dinocysts respectively, excluding indeterminate grains/cysts, fern spores and other algae, which have been also counted.

In case of sediment trap material, each sample was counted to a minimum of 100 identified pollen grains. For the charcoal analysis, all black organic particles were counted. Charcoal concentration was calculated on the base of bulk dry weight (particles per $\mathrm{g}$ ).

\subsubsection{Methods of data analysis}

The percentages diagrams for pollen/spore and dinocysts were created in TILIA/TGView and subdivided into local zones, which were established empirically by comparing dynamics of the principal taxa, supported by the results of constrained cluster analysis by sum-of-squares using CONISS for TILIA (Grimm, 1987). The stability of the classification and the sharpness of the clusters were checked with the help of bootstrap resembling performed in MULTIV (Pillar and Orlóci, 1996; Pillar, 1999).

To study relationship between pollen taxa and dinocysts, multivariate data analysis with the programs CANOCO and CanoDraw (ter Braak and Šmilauer, 1997; Leps and Šmilauer, 2003) was carried out. If a detrended correspondence analysis (DCA) had revealed a gradient length less or equal to 2.0 for the first PCA axis, principle component analysis (PCA, chapter 3) or redundancy analysis (RDA, chapter 4) was carried out as recommended by Leps and Šmilauer (2003) for data sets with short environmental gradients. If not state otherwise, standardization and logarithmic transformation was applied to species and palaeorelevé data.

To obtain insight into the similarity/dissimilarity of the pollen and dinocyst datasets and to estimate how well the two datasets match to each other in terms of compositional gradients, Procrustes analysis (PA, chapter 3) (Jackson, 1995) was applied using the CANOCO 5 software package (Gower, 1975; Peres-Neto and Jackson, 2001; Šmilauer and Lepš, 2014). In order to evaluate the significance of the RDA axes (chapter 4), the null hypothesis test was applied using the nonparametric Monte Carlo permutation test (Manly, 1992). 


\subsubsection{GIS Methods}

This thesis presents a number of original maps created in order to show present patterns of the most important sea water parameters in the Java Sea (Fig. 1.3), winds and marine currents in the area (Fig. 1.4) and geospatial distribution of main vegetation types (Fig. 1.5) in Indonesia as well as the peculiarities of modern tree-cover and burnt vegetation (Fig. 1.7). Environmental data were derived from the World Ocean Atlas (2009) and The Giovanni Ocean Colour Radiometry Portal (http://gdata1.sci.gsfc.nasa.gov/daac-bin/G3/gui.cginstance_id=ocean_8day). Maps presenting oceanographic information were created using World Ocean Atlas (2009) and Ocean Data View software (Schlitzer, 2014). Maps of vegetation (Fig. 1.5) and tree cover/burnt vegetation patterns (Fig. 1.7) were created in Quantum GIS (http://qgis.osgeo.org). Data were partly derived from GEONETWORK open source (http://geonetwork-opensource.org) and partly from Stibig et al. (2002). All data were standardized and divided into classes.

\subsection{Overview of the study area}

\subsubsection{Geography of the Java Sea}

The Java Sea is a large $\left(310,000 \mathrm{~km}^{2}\right)$ sea on the Sunda Shelf which lies between the islands of Borneo to the north, Java to the south, Sumatra to the west, and Sulawesi to the east (Fig. 1.4). In its western part, it is connected with the Indian Ocean by the Sunda Strait, and northward to the South China Sea by the Karimata Strait. The eastern part is connected with the Flores Sea and the Makassar Strait (Durand and Petit, 1995; Genia et al., 2007). Because of its geographical position, the Java Sea is strongly influenced by the tides from both the Pacific and Indian Ocean through the Malaka and the Makassar Straits respectively (Wrytki, 1961; Genia et al., 2007).

Being shallow (average depth is about $40 \mathrm{~m}$ ), the Java Sea allows a good mixing of water masses, creating homogenous layer from the surface to the bottom. Sea surface temperature (SST, Fig. 1.4A) has a small variation during the year, about $2^{\circ} \mathrm{C}$ (Wrytki, 1961). Sea surface salinity (SSS, Fig. 1.4B) is relatively constant throughout the year as well, with the average minimum salinity being 31.8 from January to June and maximum average salinity being about 34 in September (Veen, 1953). As a result of local evaporation, in the eastern part salinity varies between about 30.8 to 34.3 (Durand and Petit, 1995).

In the western part of the sea, where a number of the rivers discharge from Sumatra (e.g. Asahan, Rokan, Kampur, Batangan, Musi), Java (e.g. Bengawan Solo, Brantas, Citarum) and Kalimantan (e.g. Pembuang, Seruyan, Mendawai, Barito), SSS is lower, from 30.6 to 32.6. The average minimum of 
salinity is near 32 occurring from January to June, while the maximum is about 34 and taking place in September (Veen, 1953).

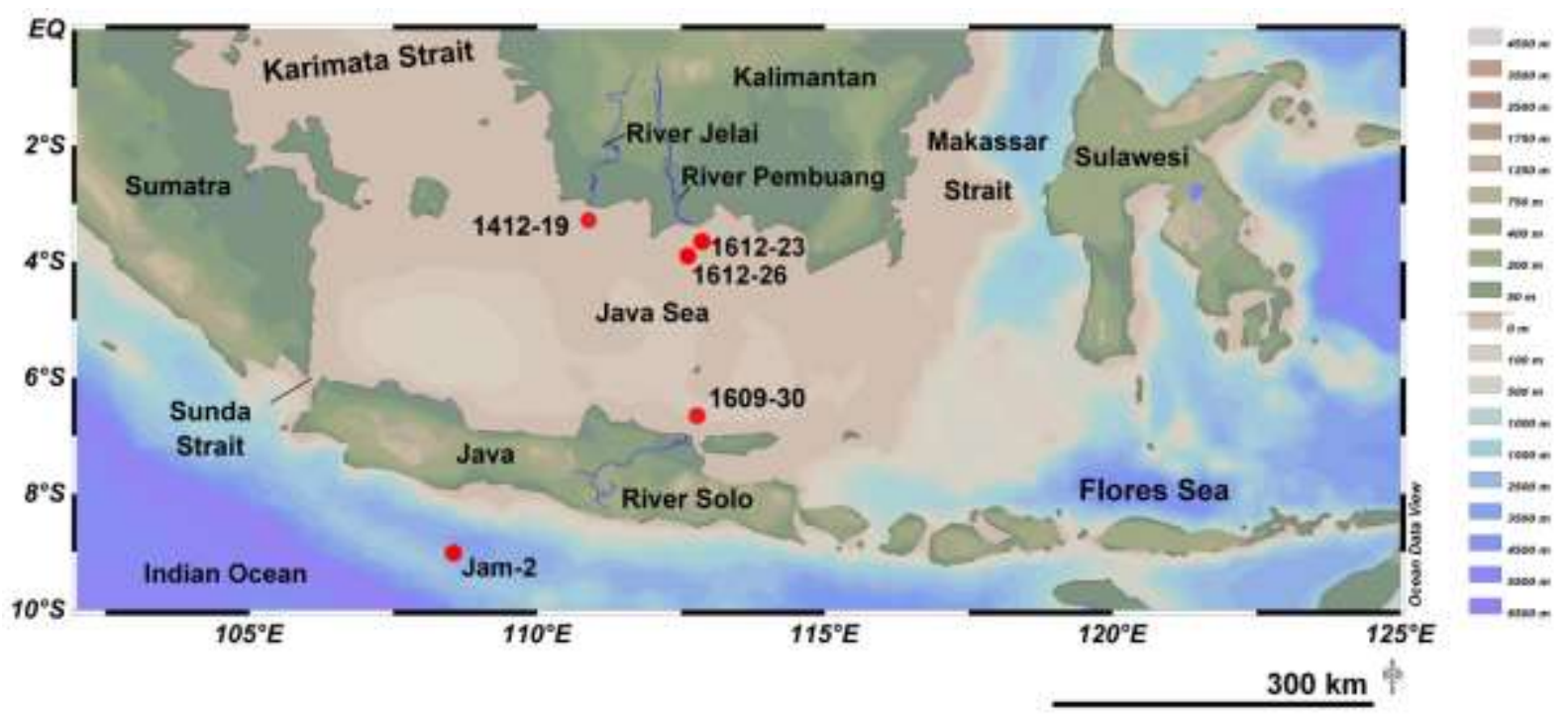

Fig. 1.3. Schematic map of the study area. Positions of marine sediment cores and a sediment trap are shown with red dots.

Whole water mass of the Java Sea is well oxygenated (Fig. 1.4C). Measured water dissolved oxygen is about 4.5-4.7 $\mathrm{ml} \mathrm{I}^{-1}$ near by the bottom and up to $5 \mathrm{ml} \mathrm{I}^{-1}$ at the surface (Doty, 1963; Boely et al.,1991). The water is relatively rich in nutrients. According to the World Ocean Atlas (2009), the average content of nitrates is $0.27-0.75 \mathrm{ml} \mathrm{I}^{-1}$ with relatively high concentrations off $\mathrm{S}$ Kalimantan (Fig. 1.4D). The phosphates concentration varies from $0.2 \mathrm{ml} \mathrm{l}^{-1}$ in the central part to $0.4 \mathrm{ml} \mathrm{l}^{-1}$ between the coastal lines of W Java and E Sumatra (Fig. 1.4E). The highest concentrations of the chlorophyll $a$ are observed in the eastern part of the sea between Java and Madura as well as off $S$ Sulawesi (Fig. 1.4F).

A

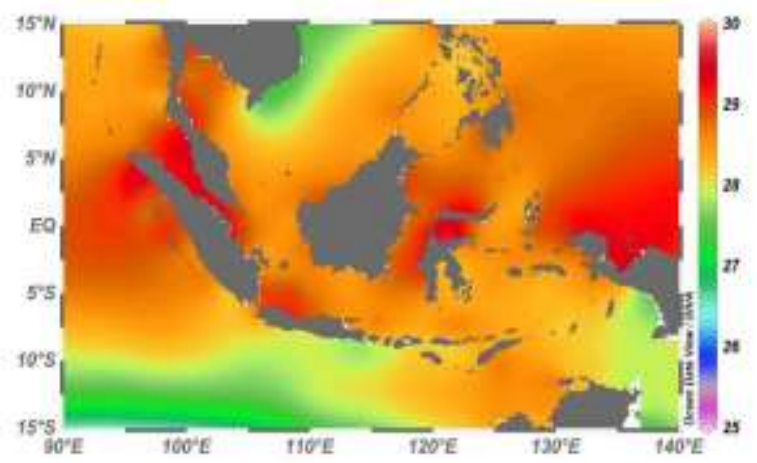

B

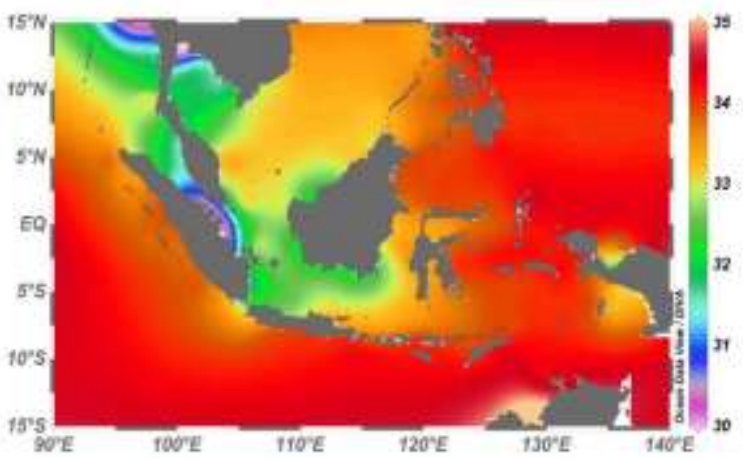




\section{C}

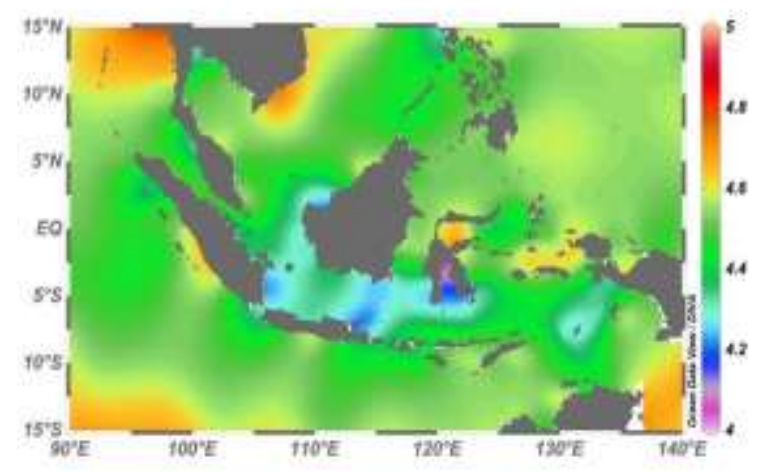

$\mathrm{E}$

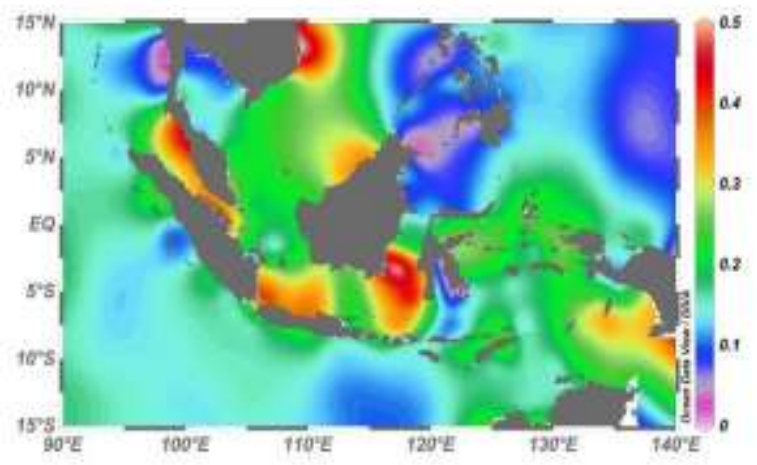

D

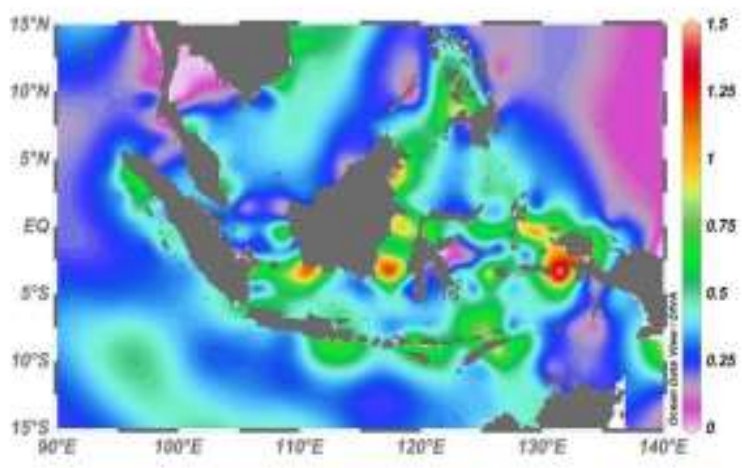

$\mathrm{F}$

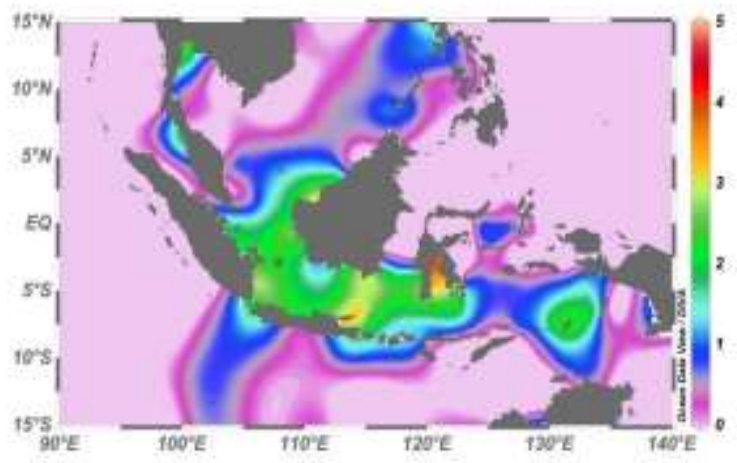

Fig. 1.4. Annual see surface temperature, SST (A), annual sea surface salinity, SSS (B), and concentrations of the oxygen (C), nitrates (D), phosphates (E), and chlorophyll-a concentration (F) in the surface waters of Java Sea. Environmental data (SST, SSS, oxygen, nitrate and phosphate concentrations) are derived from the World Ocean Atlas (2009); data on chlorophyll-a concentration derived from The Giovanni Ocean Colour Radiometry Portal).

\subsubsection{Modern climate and marine currents}

The region has a typical monsoon climate marked by a reversal of the winds. This phenomenon is caused by differences in temperature between the continental and oceanic areas. The NW monsoon reaches its peak in December to February and it is usually characterized by frequent rainfall and windy period, when the rate of precipitation in some areas is up to $3000 \mathrm{~mm}$. In contrast, the SE monsoon occurs in June to August and it is usually characterized by low rainfall, sometimes less than $50 \mathrm{~mm}$. The rate of precipitation is strongly influenced by the climate anomaly known as ENSO (EI Niňo Southern Oscillation), with its two extreme faces, El Niňo and La Niňa, it can respectively decrease and increase precipitation rates over Indonesia (Ropelewski and Halpert, 1987).

The ocean currents in the Java Sea show the same directions (Writky, 1961). From November to March, the water flows eastwards (Fig. 1.5A). Oppositely from May to September, it flows westwards (Fig. 1.5B). Waters are spiced by the Karimata Strain Throughflow (KMST) that has its origin in the South China Sea (Fig. 1.5). In the most eastern part of the Java Sea, additional inflow comes from the 

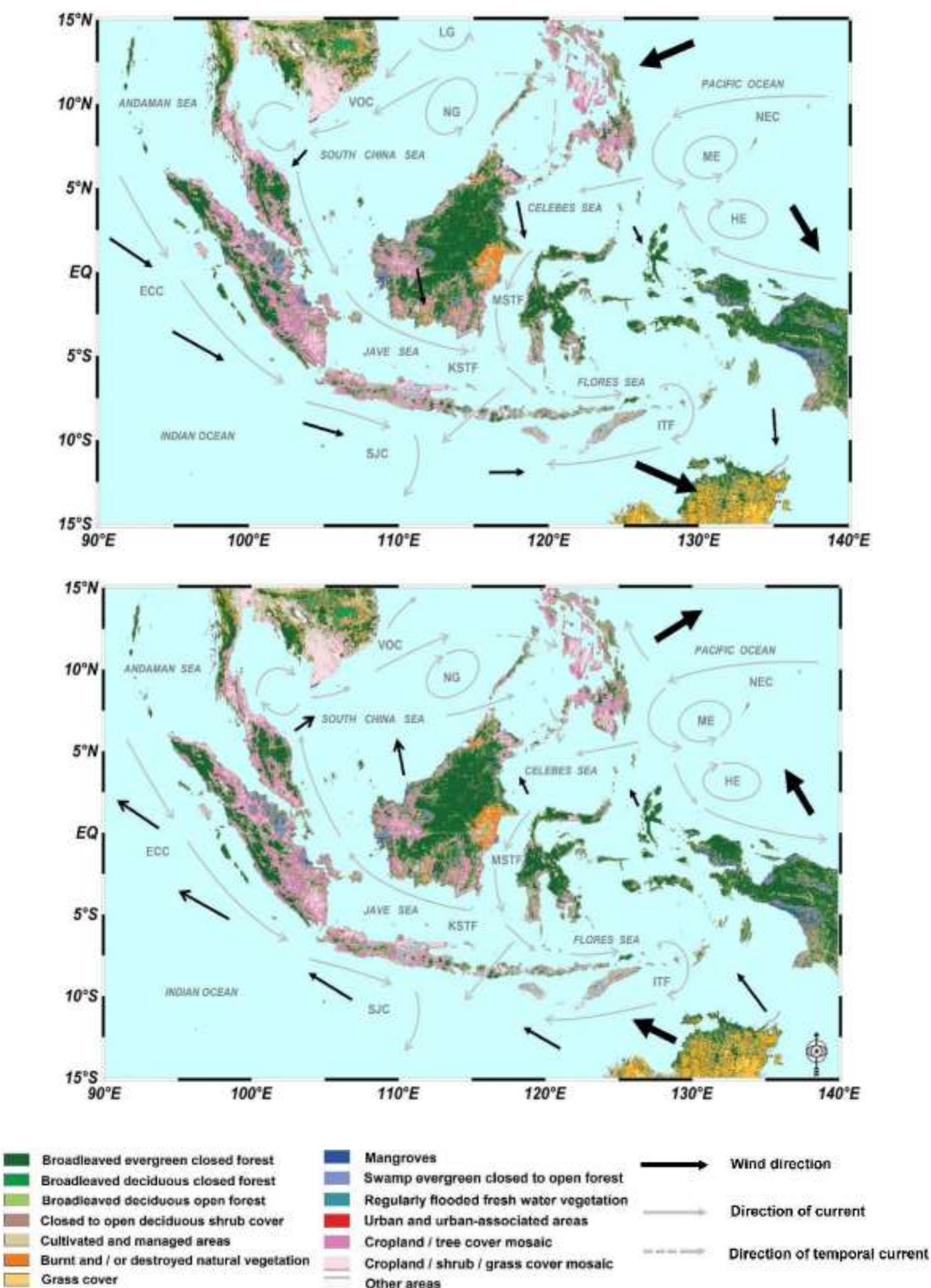

Fig. 1.5. Schematic map showing main forest types in Indonesia (after Stibig, et al., 2002) main oceanic currents and winds in the source area during the NW (upper picture) and SE monsoon (lower picture). Patterns of winds are followed Black (2002) and P. Wang et al. (2000, 2005); directions of currents are modified after Schott and McCreary (2001), Zheng et al. (2006), Fang et al. (2009). The abbreviations stand for the following: ITF, Indonesian Throughflow; ECC, Equatorial Counter Current; KSTF, Karimata Strait Throughflow; LG, Luzon Gyre; MSTF, Makassar Strait Throughflow; NG, Nansha Gyre; VOC, Vietnam Offshore Current. 
north in form of the Makassar Strait Throughflow (MTSF). These waters mix with the KMST and leave the basin through the Flores Sea. During the period of SE monsoon (May-September) their direction changes and waters go western direction (Fig. 1.5B). Waters of the Java Sea are then formed by MTSF waters that leave the Sea through the Karimata Strait. During the intermediate months (April and October) when the current direction changes numerous eddies are formed. In these months the currents off the coast of Java generally flow in easterly direction whereas at the same time a western current is present off the coast of Kalimantan (Genia et al., 2007).

The Indonesian Throughflow (ITF) flows through the Lombok Strait and neutralizes lower sea surface temperatures off Java during the upwelling season (Romero, 2009). The Indonesian region is referred to as 'a key area along the return branch of the global conveyor belt' and the only low-latitude pathway between the Pacific and Indian Ocean basins, with major climatic importance on a global scales (Gordon, 2005). Advection of fresher Java Sea waters through the Sunda Strait and run-off from Sumatra and Java are responsible for the low-salinity 'tongue' in the South Java Current (Qu et al., 2005).

\subsubsection{Bottom sediments}

The most of bottom sediments of the Java Sea is represented by silt and formed by highly dense mud layer, with large muddy bed in the North-East and central area where it is mixed with coral and shell debris (Emery, 1972; Boely et al., 1991; Sadhatomo, 1996). North of Madura and near the coast of Java, rocky outcrops associated with coral formations are observed (Boely el al., 1991). A line extending from east to west through the Java Sea roughly divides the bottom sediments of the region into two distinct groups: sediments to the north are largely derived from the non-igneous formations of Borneo, while those to the south were derived from the volcanic rocks of Java. Coarse quartz sand is found in the vicinity of the several entrances to the sea, but the great central basin is mainly composed of soft mud that is rich in calcium carbonate originated from the coral reefs (Genia et al., 2007).

\subsubsection{Geography and natural conditions of Java and Kalimantan}

The island of Java is of about $130,000 \mathrm{~km}^{2}$ supporting $136,563,000$ inhabitants with the average density of 862 people/km² (2010, http://www.bps.go.id; Whitten et al., 1996). Java is the world's most populous island, and one of the most densely-populated places in the world. It is the home of $60 \%$ of the Indonesia population. 
Kalimantan (539,760 km², http://www.geohive.com) in English, is the name for the Indonesian part of Borneo, while in Indonesian the term "Kalimantan" refers to the whole island of Borneo (MacKinnon et al., 1997). It is the largest island in Indonesia, $73 \%$ of the country lies within its territory. Non-Indonesian territories of the island consist of the states of Sarawak and Sabah forming together East Malaysia and independent sultanate Brunei Darussalam (http://www.bps.go.id). The climate on both of islands is tropical: hot and humid. Kalimantan is situated on the equator, within the wettest part of the Indonesian archipelago, and mostly its climate has less seasonal variability, than on Java.

\subsubsection{Relief and Geology}

On its origin, Java is a volcanic island with some 155 centers of active volcanism. Together with Bali, Java is the most volcanically active place on the Earth. The relief of Java is not uniform. Two large chains of mountains are found which are up to $3200 \mathrm{~m}$ high. In the north of the island, Karang, Dieng and Muria volcanic complexes are situated. Lowlands in the north of Java are represented by northern foothills and alluvial plains. Although volcanic rocks on Java dominate, the rocks in northern lowlands are almost entirely sedimentary in origin (Whitten et al., 1996). The basic lithography of the region is one of young, mixed volcanic and calcareous marine sediments lying on the southern flank of series of young volcanic piles aligned along the centre of the islands (Van Bemmelen, 1970). The island's main rivers flowing into the Indian Ocean are the Cimandiri, Cibuni, Ciwulan, Citanduy, Serayu, Progo, and Opak (after Whitten et al., 1996).

In contrast to Java, Kalimantan is rather flat and has vast areas of low costal and river plains, especially in the south (MacKinnon et al., 1997). Over half of the island lies below 150m in altitude. Moreover, Kalimantan Kalimantan has no active volcanoes, although its main mountains are igneous of origin and are mainly concentrated in the northern and in the central part of the island. Southern Kalimantan is in great part swampy lowland, stretching from around Banjarmasin and Aluh-Aluh in the south to around Amuntai in the north (Sumawinata, 1998a, 1998b). Only highland area can be found in Kalimantan, the Meratus Mountains (highest point Gunung Besar, $1892 \mathrm{~m}$ ) which extends along the coast and separates Central and East Kalimantan. Much of island consists of consolidated and semi-consolidated rocks, including Quaternary limestones, old volcanic rocks and Tertiary sediments. Large areas of Southern Kalimantan are composed of sedimentary rocks such as sandstones and shales. Loosely consolidated sands and gravel terraces, often overlain by yang, superficial deposits of peat and alluvial fans deposited by flooding rivers can be found almost in all 
area. The most important rivers in the south part of the island are the Pembuang, Barito, Mendawai, and Jalai.

\subsubsection{Soils}

Soil conditions are important in affecting the development and diversity of the vegetation. Soils of Java vary from undeveloped, soft muddy hydraquents and sandy tropopsamments to vitradepts, slightly weathered volcanic ash soils with dominantly coarse textures and thick, black topsoil, and highly productive tropical mature soils. Most of soils in the hilly parts of Java are relatively immature, however, and because they retain moisture, mineral nutrients, organic matter and phosphorus, they are potentially very productive. Exceptions are the soil over limstones and marls (Whitten et al., 1996).

The majority of Kalimantan soils have developed on rolling plains and dissected hills on sedimentary and old igneous rocks. These soils range from strongly weathered and acid ultisols to yang inceptisols. In the south, extensive alluvial plains and peat soils extend into the Java Sea. Accretion is still occurring on the shallow shelf of southern Kalimantan, with alluvial sediments building up behind coastal mangroves. Weathering is very strong in the humid tropics, favored by both warmth and moisture. High levels of weathering, leaching and biological activity, e.g. degradation of organic material, are characteristic of many soils in both islands (Burnham, 1984; MacKinnon et al., 1997). The soils of Kalimantan are generally much less fertile than the rich volcanic soils of Java.

\subsubsection{Flora and vegetation}

Floristically, Java and Kalimantan are among of the richest sites on earth. Taxa from East Asian and Austral-Antarctic floristic regions can be found in mountains, while Indo-Malaysian elements are reviling and are rich in species in the hot lower altitudes (e.g. Dipterocarpaceae), East Asiatic taxa (e.g. Fagaceae) progressively become more diversified upslope to mid altitudes. Austral-Antarctic taxa (e.g. Ranunculus, Dacrycarpus, and Leptospermum) are found at higher elevations (Hotta, 1974). Forest types of the area include mangroves, peat swamp and freshwater swamp forests, extensive heath forests, lowland dipterocarp forests, ironwood, forests on limestone and ultrabasic soils, hill forest and various montane formations (e.g. Flenley, 1979; Whitten et al., 1996; Collins et al., 1991) (Fig. 1.5). Other plant communities are represented by beach vegetation, grassy shrublands, grasslands, estates and agricultural ecosystems (MacKinnon et al., 1997). 
The vegetation of Java can be classified in a number of different ways (Campion and Seth, 1968; Whitmore, 1984; MacKinnon et al., 1982; MacKinnon and MacKinnon, 1986; Whitten et al., 1996). Natural forests include several forest subtypes, i.e. extensive evergreen rainforest (monsoon forest), semi-evergreen rainforest, moist deciduous forest along the northern coast, and dry deciduous forest. The differences are mostly related to the seasonality of rainfall. No single tree family dominates the forests of Java, as is the case with the dipterocarps in Kalimantan (Whitten et al., 1996). The most common species in the rainforests of Java are Artocarpus elasticus (Moraceae), Dysoxylum caulostachyum (Meliaceae), Lansium domesticum (Meliaceae) and Planchonia valida (Lecythidaceae). Semi-evergreen rain forest differs from evergreen rain forest by being slightly more seasonal, with two to four dry months each year (Whitten et al., 1996).

Java's deciduous forests generally are lightly closed, with few trees exceeding $25 \mathrm{~m}$. Borassus and Corypha palms are good indicators of the seasonal climates that generate deciduous forests in the region. Moist deciduous forests have 1500 to $4000 \mathrm{~mm}$ of rainfall annually, with a four- to six-month dry season. Dry deciduous forests have less than $1500 \mathrm{~mm}$ of annual rainfall and more than six dry months. Common lowland deciduous trees found in eastern Java and Bali are Homalium tomentosum, Albizia lebbekoides, Acacia leucophloea, A. tomentosa, Bauhinia malabarica, Cassia fistula, Dillenia pentagyna, Tetrameles nudiflora, Ailanthus integrifolia, and Phyllanthus emblica. Many herbaceous plants are confined to the deciduous forests (Whitten et al., 1996). Patches of freshwater swamp forest found throughout the ecoregion are relatively poor in species (Whitten et al., 1996). Rawa Danau, Banten in west Java is the largest remaining area of swamp forest in Java and Bali, and it contains many tree species now nearly extinct elsewhere in Java, such as Elaeocarpus macrocerus, Alstonia spathulata, wild mango (Mangifera gedebe) and Stemonurus secundiflora.

According to Stuijts (1993) and Stuijts et al. (1988), mountain vegetation of Java has a distinct belt structure and can be described it is shown at the scheme (Fig. 1.4). Submontane forest is closed, with little moss and poor ground flora. It is represented by seasonal mountain forest, growing above 1000-1400 m following evergreen or semi-evegreen forest, and mountain aseasonal forest, at the same elevation above monsoon forest. Common trees are Celtis, Altingia and Myrtaceae. Lower montane forest differs from the previous forest type by very rich ground flora and lower number of tree species. It is observed at the level of $1400-1800 \mathrm{~m}$. This zone is often caller 'Lauro-fagaceous belt' as Castanoptis together with Quercus and Lauraceae predominant. Many lowland families no longer appear (Backer et al., 1963, 1968), more temperate genera, including Lonicera, Nertera, Gaultheria appear (Whitmore, 1975). Mountain vegetation is upper mountain forest growing at the elevation of 1800-2400 $\mathrm{m}$ is described as closed, high-stem, floristically rich mossy mesophyll forest with Podocarpus, Dacrycarpus, Engelhardia being characteristic trees. Ericoid montane forest can be 
found on the level of $2400-3000 \mathrm{~m}$. It is mossy microphyll forest, consisting of a single low canopy with rich ground flora and few lianas. Device Ericaceae, Rapanea and on volcanic soils Myrica can be found there. Subalpine ericoid scrub appeared when elevation riches 3000-3600 m. Herbs and low microphyll shrubs, dwarf forms of trees found in below vegetation are recognized there. In the uppermost sites alpine rock-desert occurs.

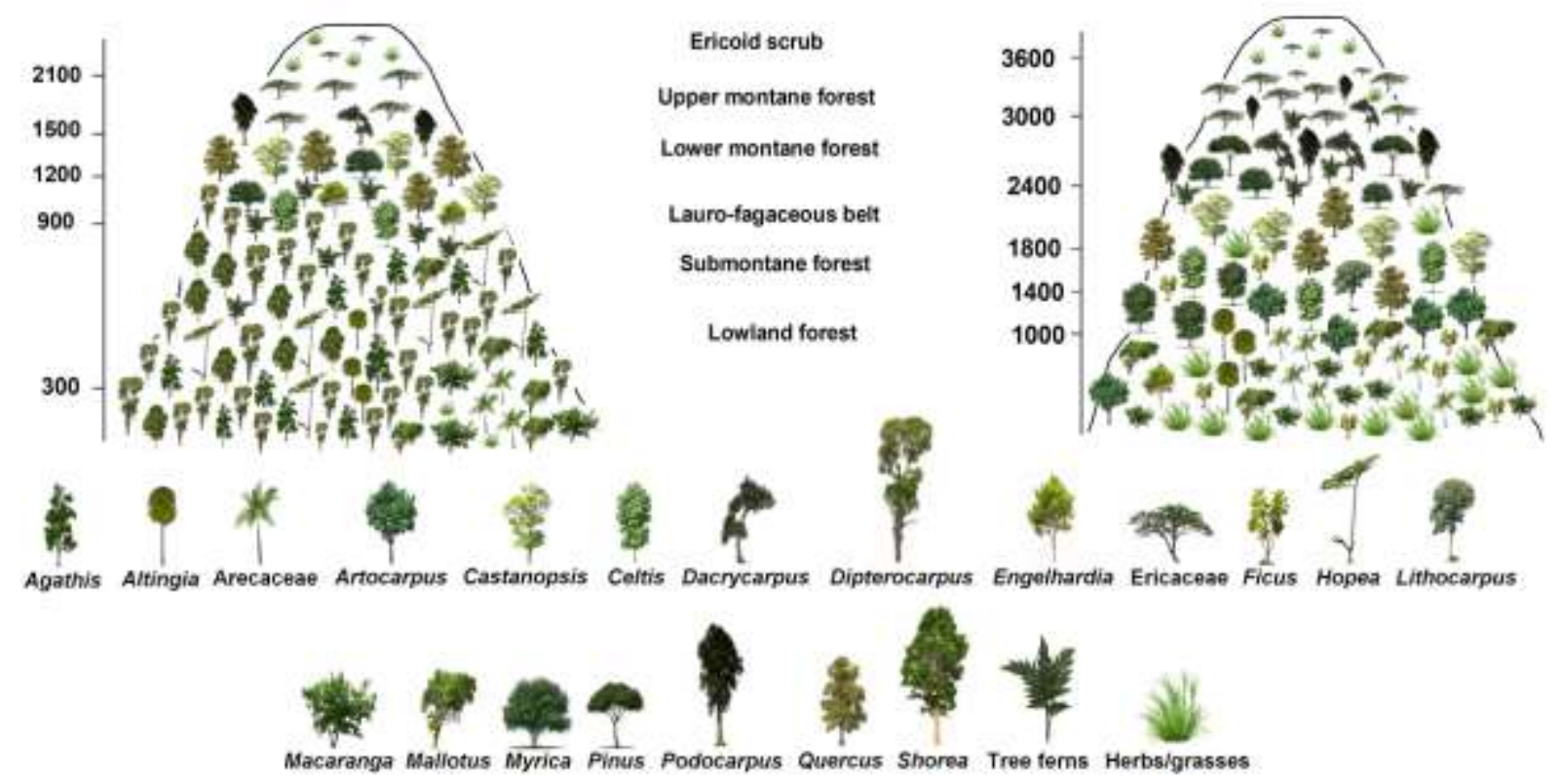

Fig. 1.6. Vertical zonation of Javanese (based on Stuijts, 1993 and Stuijts et al., 1988) and Kalimantan (based on Whitmore, 1984a and MacKinnon et al., 1997) mountains with the characteristic taxa and vegetation belts.

The vegetation of Java has been strongly changed by humans during the last few hundred years. Over the half the original area has been turned into grassy shrubland with Trema, Malotus, Melastoma, Lantana, and Eupatorium. Extensive palm plantations and rice fields as well as abandoned estates and aquaculture land occupy nowadays large territories. Strongly reduced area of mangroves is now limited to the stands along the northern coasts of Java (e.g. around Ujung Kulon), in Segara Anakan lagoon (White et al., 1989; Yani et al., 2004; Hinrichs, 2006; Noor et al., 2006; Hinrichs, et al., 2009; Geist, 2007, Geist et al., 2012;) and in Grajagan Bay, Segoro Anak (White et al., 1989; Whitten et al, 1996). The most important families in mangrove forest of Northern Java are Rhizophoraceae with Rhizophora, Bruguiera, Ceriops followed by Avicenniaceae (Avicennia) and Sonneratiaceae (Sonneratia).

Kalimantan supports some of the largest expanses of tropical rainforest is SE Asia, providing some of the most spices-rich habitat on earth. Most of Kalimantan is covered by species-rich closed-canopy forests with high endemism (e.g. Whitmore, 1984; Jacobs, 1988; MacKinnon et al., 1997) very high productivity (Ashton, 1982; MacKinnon et al., 1997), long history (Muller, 1970) and a great diversity; there are as many as 240 different species of trees growing within a hectare (Kartawinata et al., 
1981; Ashton, 1989). Main types of lowland rainforest of southern Kalimantan are Dipterocarp forest, heath forest (Kerangas), ironwood forests predominating by Eusideroxylon zageri as well as forests on limestones and ultrabasic rocks. The general characteristics of these forests are canopies $24-36 \mathrm{~m}$ high with emergents reaching up to $65 \mathrm{~m}$. Dipterocarpaceae is a dominant family in the emergent stratum. In the richest forests, up to $80 \%$ of the emergent trees are dipterocarps: Dipterocarpus, Dryobalanops, Shorea, Hopea and Vatica together with species from Berseraceae and Sapotaceae are usually found in the main canopy as well. A third layer occurs below the canopy of shade-tolerant species, adorned with lianas, orchids, and epiphytic ferns. This layer includes many species from the Euphorbiaceae, Rubiaceae, Annonaceae, Lauraceae, and Myristicaceae families. In some cases Euphorbiaceae is more common than dipterocarps, being the second most common family in Kalimantan. On the forest floor, herbs, seedlings, and shade-tolerant palms exploit the few places that receive sunlight.

In mountains of Kalimantan Whitmore (1984) described five altitudinal floristic zones (Fig. 1.6). These are already described lowland dipterocarp zone (less than $300 \mathrm{~m}$ ), the hill dipterocarp zone (300-800 $\mathrm{m})$, the upper dipterocarp zone (800-1200 m), the oak-chestnut zone with Fagaceae and Lauraceae predominant (1200-1500 m), and the montane ericaceous zone (higher than $1500 \mathrm{~m}$ ). Upper montane forests share many species and features of the structure and appearance with heath forests (Eugenia, Rhododendron, Vaccinium), yet none of the heath forest dipterocarps expends above 1,500 $\mathrm{m}$. Only few plants span the complete altitudinal range from lowlands to upper montane forest, e.g. Dacrydium (MacKinnon et al., 1997). The highest altitudes of Southern Kalimantan bare closedcanopy scrubs.

Mangroves fringe most of Kalimantan coastline. They occur almost in all bays and lagoons, along the deltas of major rivers, with particularly extensive stands at mouths of the Kapuas, Mahakam and Sebuku. The most important taxa in mangroves of Southern Kalimantan are Rhizophora, Bruguiera and Xilocarpus. In older stands they may be an understory of Ceriops tagal (Soegiarto and Polunin, 1980). Sonneratia alba, Avicennia alba and A. marina and are important for pioneer communities. Dryer areas are colonised by Bruguera, Lumnitzera, Aegiceras, Exocoecaria, and Osbornia. Acantus ilicifolius can appear along the edge of estuarine mangroves. Along tidal rivers Sonneratia caseolaris grows. Stands of Nypa fruticans, only mangrove palm, flourish inland, along tidal creeks and estuaries; a few leans may occur (e.g. Derris), and ferns, grasses and sedges sometimes colonise openings (Chapman, 1977). In sites where mangroves have been disturbed, the giant fern Acrostichum aureum may form dense undergrowth, so thick that the mangrove trees cannot regenerate. Main agricultural landscapes of the Kalimantan are oil palm plantations with minor rice field development compare to Java. 


\subsubsection{Anthropogenic Impact}

Very small areas of natural habitats remain in Java (MacKinnon and MacKinnon, 1986). Anthropogenic fires are common (Fig. 1.7), and over the centuries burning has resulted in monospecific stands of fire-resistant species in some areas, usually Tectona grandis (FAO, 1981) and Casuarina. In many annual cropping systems, soils are left exposed, resulting in extensive erosion.

In freshwater swamp forests, the exotic Mimosa pigra has the potential to become a very serious pest because it is fire-resistant and capable of forming impenetrable thickets. Plans to construct a dam at the outlet of the Cidanau River will potentially destroy Rawa Danau, the only remaining extensive area of freshwater swamp in Java (Whitten et al., 1996). Illegal farming and logging (Fig. 1.7) even within protected areas are widespread, and an important timber tree Altingia excelsa has been nearly eliminated from the lowland forests (Whitten et al., 1996).

Reforestation takes place on Java since the colonial time period, while in Kalimantan tree gain is going on due to a natural recover (Fig. 1.8). Planted species include Swietenia macrophylla, Pinus

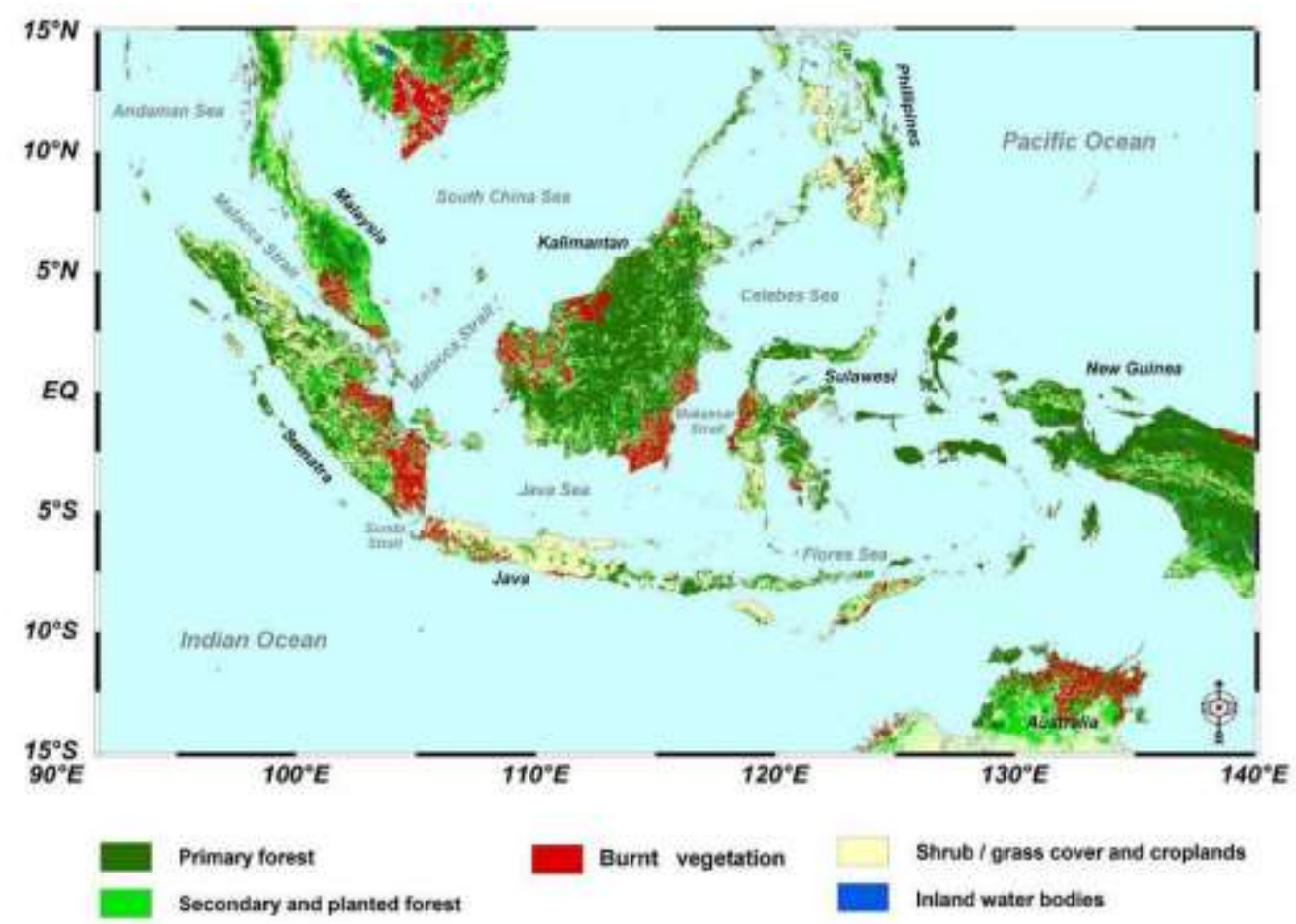

Fig. 1.7. Tree cover in Indonesian archipelago in comparison with shrub/grass cover, secondary/planted vegetation and burnt vegetation.

merkusii, Agathis damara and some native taxa, such as Altingia excelsa, Schima noronhae, and Quercus sp. (Smiet, 1990). These plantations are established mostly in areas where restoration of forest cover was deemed essential for the reason of watershed protection (Whitten et al, 1996). 
In Kalimantan, rapid logging, fires and periodical droughts, that take place due to the warm phase of the El Niño Southern Oscillation (ENSO), cause a problem of deforestation (Goldammer and Seibert, 1989; Cleary and Priadjati, 2005), although, in pristine forests fire rarely escape the ground vegetation because of the high humidity.
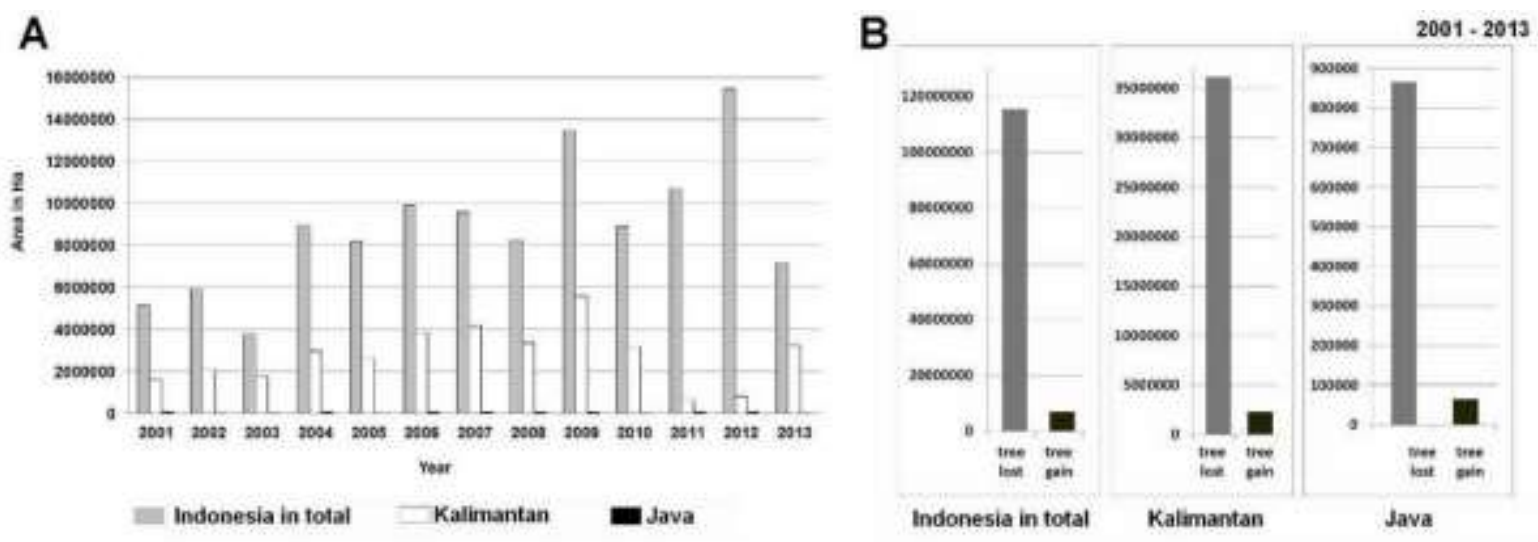

Fig. 1.8. Forest cover lost in Indonesia in total, Kalimantan and Java from 2001 and 2013 (A) and comparison between tree cover lost and tree cover gain (B). Data are derived from Margono et al., 2014; http://nfms.dephut.go.id/ipsdh.

However, tropical rainforests that have been previously logged are fire-prone because large amounts of wood are left on the forest floor, and the forest canopy is opened, drying out the ground vegetation. Oil and sugar palm plantations development as well as aquaculture (shrimp and fish ponds) are also the drivers of deforestation in the Kalimantan contributing directly and indirectly. About half of all presently productive plantations (over 6 million ha) were established in secondary forest and bush areas. Protection laws are in 'effect throughout Borneo but are often inadequate or are violated, usually without any consequences' (Fatawi and Mori, 2000).

\subsection{References}

Ashton, P. S., 1982. Dipterocarpaceae. Flora Malesiana Seria I (9), 237-552.

Ashton, P. S., 1989. Sundaland. In Floristic inventory of tropical countries. (eds.) D.G. Campbell., and H.D. Hammond), pp. 91-99. New-York Botanical Garden, New-York.

Backer, C.A., van den Brink, R.C.B., 1963. Flora of Java. Volume I; III. Noordhorff, Groningen.

Bengo, M.D., 1997. La sédimentation pollinique dans le Sud-Cameroun et sur la platforme marine à l'époque actuelle et au Quaternaire récent: études des paléoenvironnements. Thesis Université Montpellier II, Languedoc, 220p.

Black, D.E., 2002. The rains may be 'a-comin'. Science 297, 528-529.

Boely, Y T., Lining, M., Cremoux, J.L., Petit, D., Potier, M., Nurhakim, S., Sujianto, S., 1991. Estimation of the abundance of pelagic fish in the central part of the Java Sea (Indonesia). Marine Fisheries Research Institute, 58-107.

Burnham, C.P., 1984. The forest environment: soils. In: Tropical Rain Forest of the Far East, ed. T. C. Witmore. Oxford, Clarendon, 137-154.

Chapman, V.J. (ed.), 1977.Ecosystens of the World I. Wet Ecosystems. Elsevier, Amsterdam. 
Collins, N. M., Sayer, J. A., Whitmore, T. C., 1991. The Conservation Atlas of Tropical Forests: Asia and Pacific. Macmillan Press, London.

Davey, R. J., Rogers, J., 1975. Palynomorph distribution in recent offshore sediments along two traverses off South West Africa. Marine Geology 18, 213-225.

Davey, R.J., 1971. Palynology and palaeo-environmental studies with special reference to the continental shelf sediments of South Afria. In: Farissacci, I. (Ed.) Proceedings of the II planktonic conference Roma 1970 (I), 331-347.

Doty, M.S., Soeriaatmadja, R.E., Soegiarto, A., 1963. Observations on the primary marine productivity 01 Northwestern Indonesian Waters. Marine Research in Indonesia, 5-125.

Dupont, L., Agwu, M., Chiori, O.C., 1991. Environmental control of pollen grain distribution patterns in the Gulf of Guinea and offshore NW-Africa. Geologische Rundschau, 80 (3), 567-589.

Dupont, L.M., Schneider, R., Schmüser, A., Jahns, S., 1999. Marine-terrestrial interaction of climate changes in West Equatorial Africa of the last 190,000 years. Paleoecology of Africa 26, 61-84

Durand, R., D. Petit, 1995. The Java Sea Environnment. In: BIODYNEX: Biology, Dynamics, Exploitation of the Small Pelagic Fishes in the Java Sea, M. Potier and S. Nurhakim (eds.), AARD/ORSTOM, 14-38.

Emery, K.O., Uchupi, E., Sunderland, J., Uktolseja, H.L., Young, E.M., 1972. Geologlcal structure and some water characterislics 01 the Java Sea and adjacent continental shell. Uniled Nations ECAFE, CCOP Tech. Bull., 6, 197-223.

Fang, G., Wang, Y., Wei, Z., Fang, Y., Qiao, F., Hu, X., 2009. Interocean circulation and heat and freshwater budgets of the South China Sea based on a numerical model. Dynamics of Atmospheres and Oceans 47, 55-72.

FAO, 1981. Food and Agricultural Food and Agriculture Organization of the United Nation: The global assessment of tropical forest recourses. GEMS PAC Information series, 3.

Fatawi, M., Mori, T., 2000. Description of Forest and forestry in East Kalimantan. In: Guhardja, E., Fatawi., M., Sutisna, M., Mori., T., Ohta. S., (eds.) Rainforest ecosystems of East Kalimantan. 311.

Flenley, J.R., 1979. The equatorial rain forest: a geological history. Butterworth, London.

Gallery of common sediment sampling devices: http://woodshole.er.usgs.gov/openfile/of20051001/htmldocs/sediment_traps.

Geist, S. J., Nordhaus, I., Hinrichsc, S., 2012. Occurrence of species-rich crab fauna in a humanimpacted mangrove forest questions the application of community analysis as an environmental assessment tool. Estuarine, Coastal and Shelf Science 9, 69-80.

Geist, S., 2007. Die intertidale Krabbengemeinschaft der Segara Anakan Lagune (Java, ndonesien) in der Trockenzeit: Artenzusammensetzung, Biomasse und Zonierung. Diploma thesis, University of Bremen, Germany.

Genia, A.N., Nugroho, A.S., Olugbenga, J.O., 2007. Introduction to the Java Sea. Oceanography, University of Stavanger.

Goldammer, J. G., Seibert, B., 1989. Natural Rain Forest Fires in Eastern Borneo During the Pleistocene and Holocene. Naturwissenschaften 76, 518-520.

Gordon, A.L., 2005. Oceanography of the Indonesian seas and their throughflow. Oceanography 18 (4), 14-28.

Grimm, E.C., 1987. CONISS: a FORTRAN 77 program for stratigraphically constrained cluster analysis by method of incrimination sum of squares. Computers and Geosciences 13 (1), 13-35.

Heusser, L.E., 1988. Pollen distribution in marine sediments on the continental margin off northern California. Mar. Geol. 80, 131-147.

Heusser, L.E., Balsam, W.L., 1977. Pollen distribution in the northeast Pacific Ocean. Journal of Quaternary Reserch 7, 45-62.

Heusser, L.E., Balsam, W.L., 1985. Pollen sedimentation in the Northwest Atlantic: effect of the Western Boundary Undercurrent. Marine Geology 69, 149-153. 
Heusser, L.E., Morley, J.J., 1985. Pollen and radiolarian records from deep-sea core RC14-103: climatic reconstructions of Northeast Japan and Northwest Pacific for the last 90,000 years. Journal of Quaternary Reserch 24, 60-72.

Heusser, L.E., Oppo, D., 2003. Millennial- and orbital-scale climatic variability in southeastern United States and in the subtropical Atlantic during Marine Isotope Stage 5: evidence from pollen and isotopes in ODP Site 1059. Earth and Planetary Science Letters 214, 483-490.

Hinrichs, S., 2006. Die intertidale Krabbengemeinschaft der Segara Anakan Lagune (Java, Indonesian) in der Regenzeit: Artenzusammensetzung, Biomasse und Zonierung. Diploma thesis, University of Rostock, Germany.

Hinrichs, S., Nordhaus, I., Geist, S. J., 2009. Status, diversity and distribution patterns of mangrove vegetation in the Segara Anakan lagoon, Java, Indonesia. Regional Environmental Change 9, 275289, DOI 10.1007/s10113-008-0074-4.

Honjo, S., 1980. Material fluxes and modes of sedimentation in the mesopelagic and bathypelagic zones. Journal of Marine Research 38, 53-97.

Hooghiemstra, H., Agwu, C.O.C., 1986. Distribution of palynomorphs in marine sediments: a record for seasonal wind patterns over NW Africa and adjacent Atlantic. Geologische Rundschau 75, 8195.

Hope, G., A. Kershaw, Van der Kaars, S. Xiangjun, P. Liew, L. Heusser, H. Takahara, M. McGlone, N. Miyoshi, Moss, P., 2004. History of vegetation and habitat change in the Austral-Asian region. Quaternary International 118-19, 103-126.

Hotta, M., 1974. History and geography of plants. Sanseido, Tokyo. Statistica Indonesia, http://www.bps.go.id.

Jacobs, M., 1988. The tropical rain forest. A first encounter. Springer-Verlag, Berlin.

Kartawinata, K., Abdulhadi, R., Partomihardjo, T., 1981. Composition and structure of a lowland dipterocarp forest at Wanariset, East Kalimantan, Indonesia. Malay Forestry 44, 397-418.

Keil, R.G., Feng, S. H., Tsamakis, E., Hedges, J.I., 1994. Pollen in marine sediments as an indicator of oxidation of organic matter. Nature 369, 639-641.

Leps, J., Šmilauer, P., 2003. Multivariate Analysis of Ecological Data using CANOCO. Cambride University Press, Cambride.

MacKinnon, J., 1992. Nature's treasurehouse: The wildlife of Indonesia. Gramedia, Jakarta.

MacKinnon, J. M., 1986. Review of the protected area system in the Indo-Malayan realm. IUCN, Gland.

MacKinnon, J.M. 1982. National conservation plan for Indonesia, vol 1. Introduction, evaluation methods and overview of national nature richness. FAO Field Report 34, Bogor.

MacKinnon, K., Hatta, G., Halim, H., Mangalik, A., 1997. The Ecology of Kalimantan. The Ecology of Indonesia Series. V.III. Peripus Editions, Singapore.

Monterey Bay Aquarium Research Institute (MBARI). Pulse 58 Expedition, 20-28 May, 2011. http://www.mbari.org/expeditions/Smith2011/logbook/day4.htm

Moss, P.T., Kershaw, A.P., 2007. A late Quaternary marine palynological record (Oxygen Isotope Stages 1 to 7) for the humid tropics of northeastern Australia based on ODP Site 820 . Palaeogeography, Palaeoclimatology, Palaeoecology 251, 4-22.

Mudie, P.J., Rochon, A., Aksu, A.E., 2002. Pollen stratigraphy of Late Quaternary cores from Marmara Sea: land-sea correlation and paleoclimatic history. Marine Geology 190, 233-260.

Muller, J., 1959. Palynology of Recent Orinoco delta and shelf sediments: Reports of the Orinoco Shelf Expedition, Vol. 5. Marine Micropaleontology 5, 1-32.

Muller, J., 1970. Palynological evidence on early differentiation of angiosperms. Biological Rewiew.45, 417-450.

Noor, Y. R., Khazali, M., Suryadiputra, N. N., 2006. Panduan Pengenalan Mangrove di Indonesia. Wetlands International Indonesia Programme. Bogor.

Oceanographic Equipment. https://depts.washington.edu/soundcit/about/oceanographicequipment/sediment-trap-schematic. 
Pillar, V. D., 1999. How sharp are classifications? Ecological Society of America Ecology 80 (8), 25082516.

Pillar, V. D., Orlóci, L., 1996. On randomization testing in vegetation science: Multifactor comparisons of relevé groups. Journal of Vegetation Science 7, 585-592.

Qu, T., Du, Y., Meyers, G., Ishida, A., Wang, D., 2005. Connecting the tropical Pacific with Indian Ocean through South China Sea. Geophysical Research Letters 32, L24609, doi:10.1029/2005GL024698

Quantum GIS Geographic Information System. Open Source Geospatial Foundation Project. Available at: http://qgis.osgeo.org.

Ratmeyer, V., Fischer, G., Wefer, G., 1999. Lithogenic particle fluxes and grain size distributions in the deep ocean of northwest Africa: Implications for seasonal changes of aeolian dust input and downward transport. Deep-Sea Research 46, 1289-1337.

Romero, O.E., Rixen, T., Herunadi, B., 2009. Effects of hydrographic and climatic forcing on diatom production and export in the tropical southeastern Indian Ocean. Marine Ecology. Progress Series 384, 69-82.

Ropelewski, C. F., Halpert, M.S., 1987. Global and regional scale precipitation patterns associated with El Nino/Southern Oscillation. Monthly Weather Reviews 115, 1606-1626.

Rossignol, M., 1961. Analyse pollinique de sédiments marins quaternaires en Israel 1 . Sédiments récents. Pollen et Spores 3, 303-324.

Ryan, M.T., Dunbar, G.B., Vandergoes, M.J., Neil, H.L., Hannah, M.J., Newnhama, R.M., Bostock, H., Alloway, B.V., 2012. Vegetation and climate in Southern Hemisphere mid-latitudes since $210 \mathrm{ka}$ : new insights from marine and terrestrial pollen records from New Zealand. Quaternary Science Reviews 48, 80-98.

Sadhatomo, 1996. Reweys of Enveronmental Features of Java See. 1, 129 -157.

Sánchez Goñi, M.F., Cacho, I., Turon, J.L., Guiot, J., Sierro, F.J., Peypouquet, J.-P., Grimalt, J.O., Shackleton, N.J., 2002. Synchroneity between marine and terrestrial responses to millennial scale climatic variability during the last glacial period in the Mediterranean region. Climate Dynamics 19, 95-105.

Schott, F., McCreary, J.P., 2001. The monsoon circulation of the Indian Ocean. Progress in Oceanograohy $51,1-123$.

Schrader, H.-J., 1971. Fecal pellets: role in sedimentation of pelagic diatoms. Science 174, 55-57.

Silver, M.W., Shanks, A.L., Trent, J.D., 1978. Marine snow: microplankton habitat and source of smallscale patchiness in pelagic population. Science 201, 371-373.

Smiet, A. C., 1990. Forest Ecology on Java: conservation and usage in a historical perspective. Journal of Tropical Forest Science 2 (4), 286 - 302.

Soegiarto, A., Polunin, N., 1980. The marine environment of Indonesia. IUCN/WWF, Bogor.

Stibig, H-J., Beuchle, R.,Janvier, P., 2002. Forest cover map of Insular Southeast Asia at 1:5500000. TREES Publications Series D: No. 3, European Commission, Luxemburg.

Stockmarr, J., 1971. Tablets with spores used in absolute pollen analysis. Pollen and Spores 13, 61521.

Stuijts, I., 1993. Late Pleistocene and Holocene vegetation of West Java, Indonesia. Modern Quaternary Research in South-East Asia 12, A. A. Balkema Publishers, Rotterdam.

Stuijts, I., Newsome, J.C., Flenley, J.R. 1988. Evidence for Late Quaternary vegetational change in the Sumatran and Javan highlands. Review of Palaeobotany and Palynology 55, 207-216.

Sumawinata, B., 1998a. Review of environmental features of Java Sea. Southeast Asian Studies 1, 129-157.

Sumawinata, B., 1998b. Sediments of the lower Barito basin in South Kalimantan: fossil pollen composition. Southeast Asian Studies 36 (3), 293-316.

Sun, X.-J., Li, X., Luo, Yu.-L., 2002. Vegetation and climate on the Sunda Shelf of the South China Sea during the Last Glaciation - Pollen results from station 17962. Acta Botanica Sinica 44 (6), 746752. 
ter Braak, C. J. F., Šmilauer, P., 1997. Canoco for Windows. Biometris - Plant Research International, Wageningen, The Netherlands.

The Giovanni Ocean Colour Radiometry Portal. Available at: http://gdata1.sci.gsfc.nasa.gov/daacbin/G3/gui.cginstance_id=ocean_8day.

Van Bemmelen, R.W., 1970. The Geology of Indonesia. In: Nijhoff, Martinus (Ed.), General Geology of Indonesia and Adjacent Archipelagos 1A, second ed. Government Printing Office, The Hague, 732.

Veen, P.C., 1953. Preliminary charts of the mean surface salinity of the Indonesian archipelago and adjacent waters. Bulletin Organization Scientific Research in Indonesia 17, 1-47.

Wagner, T., Dupont, L., 1999. Terrestrial organic matter in marine sediments: Analytical approaches and eolian-marine records of the central Equatorial Atlantic, in The Use of Proxies in Paleoceanography: Examples From the South Atlantic, edited by G. Fischer and G. Wefer, pp. 547-574, Springer-Verlag, New York.

Wang, P., Clemens, S., Beaufort, L., Braconnot P., Ganssen, G., Jian, Z., Kershaw, P., Sarnthein, M., 2005. Evolution and variability of the Asian monsoon system: State of the art and outstanding issues, Quaternary Science Review 24 (5-6), 595-629.

Wang, P., Prell, W., Blum, P., 2000. Proceedings of the ocean drilling program. Texas A\&M University, college station TX 778445-9547. Initial Reports 184, 1-48.

Wefer, G., 1991. Stofftransport zum Meeresboden: Eine Übersicht. Naturwissenschaften 78, 1-6.

Wefer, G., 1993. Formation and composition of marine particulates. In: Heinmann, M. (Ed.) The Global Carbon Cycle. Springer, Berlin.

Wefer, G., Fischer, G., 1993. Seasonal patterns of vertical particle flux in equatorial and coastal upwelling areas of the eastern Atlantic. Deep-Sea Research 40, 1613-1645.

White, A.T., Martosubroto, P., Sadorra, M.S.M., 1989. The coastal environmental profile of Segara Anakan Cilacap, South Java, Indonesia. ICLARM technical report 25, Manila.

Whitmore, T.C., 1984. Tropical rain forest of the Far East, Oxford University Press, Oxford.

Whitmore, T.C., 1975. Tropical rain forest of the Far East. Clarendon Press, Oxford.

Whitten, T., Soeriaatmadja, R.E., Afiff, S.A., 1996. The Ecology of Java and Bali. The Ecology of Indonesia Series Vol. II, Periplus Editions, Dalhousie University, Halifax.

Yani, E., Widyastuti, A., Lestari, W., 2004. Zonasi Vegetasi Mangrove di Kawasan Segara Anakan. Biosfera, 2, 44-49.

Zheng, Q., Fang, G., Song, Y.T., 2006. Introduction to special section: Dynamic processes and circulation in Yellow Sea, East China Sea, and South China Sea. Journal of Geophysical Research 111, 1-5. 


\section{CHAPTER 2}

\section{Marine palynology in SE Asia: State of knowledge}

\subsection{Studies on fossil pollen}

Marine palynology in general, is a yang branch of research. Jan Muller was probably the first in science who linked pollen and spore distribution in marine surface sediment samples to the modern vegetation in his study on sediments from the Orinoco delta (Muller, 1959). In Indonesia, compared to the terrestrial studies, the number of publications on marine sediment records is still limited; especially it is true for the studies related to the Anthropocene and investigations of the pattern of modern pollen distribution.

In the study area, the first work on the marine palynomorphs apparently was the study undertaken by I. Van Waveren (1989) who focused on the palynological residues of the surface sediments from the Banda Sea. In that paper, 'a series of 27 palynomorph types are described and informally categorized' (Van Waveren, 1989). The author indicated a high plankton production and high sedimentation rate, although the paper does not contain any analysis of palynomorphs.

First analytical works and reconstruction of the past vegetation and climate for Indonesian region were published just in the beginning of 90s (Van der Kaars, 1991, 1989; Barmawidjaja et al., 1993; Van Waveren, Visscher, 1994). The authors indicated the practicality of marine palynology in the reconstruction of the history of this region.

\subsubsection{Mid-Holocene (ca $7000-4000$ cal yr BP)}

Warmer periods from 6300 to $6000 \mathrm{yr}$ and after $4000 \mathrm{yr}$, were evidenced in the coral records from the southern periphery of the IPWP, along with evidence for freshening after $4000 \mathrm{yr}$, indicating a stronger monsoon (Gagan et al., 1998; Stott et al., 2004; Abram et al., 2009). The Banda Sea records, including pollen and coccoliths, show a significant shift in the position of the monsoon around 6000 yr, suggesting low-latitude insolation forcing (Beaufort et al., 2010). Wang et al. (2007) indicated the warm phase between 7000 and 3600 yr BP as well. 
Reeves et al. (2013) in their review on the vegetation and climate change of the region also referred to the thermal maximum of IPWP 6800-5500 yr BP and less extreme El Niño at about 5500-4300 yr Peak wet conditions achieved about 5000 yr in Borneo. Additionally, some drier conditions were indicated there.

\subsubsection{Late Holocene (ca 4000 cal yr BP to the present)}

Ganssen et al. (1989) indicated increased monsoonal intensity at about $2700 \mathrm{yr}$, while later, between 2500 and $1700 \mathrm{yr}$; at about the same time extreme and longer El Niño events were recorded (Tudhope et al., 2001; Moy et al., 2002; Woodroffe et al., 2003; McGregor and Gagan, 2004; Gagan et al., 2004; Reeves, 2013). Coral reconstructions of ENSO for the past $1100 \mathrm{yr}$ demonstrate the links between ENSO and changes in the mean climate of the Pacific region (Cobb et al., 2003). For Borneo, warmer and fresher period are indicated (Reeves et al., 2013) up to $2500 \mathrm{yr}$ with some more extreme El Niño 2300-1700 yr, compared with present.

\subsection{Palynological studies of marine surface sediments}

According to the study on modern pollen distribution pattern in the surface sediments in the South China Sea off Borneo, we learned that pollen is mainly transported by rivers from the south islands, e.g. Borneo (Sun et al., 1999; Sun et al., 2003). Because of the long distance from the coast, pollen amount deposited in the modern South China Sea is very little (Wang, 2007).

Palynological analysis of box-core samples collected from surficial deep-sea sediments along three transects in the Banda Sea (Van Waveren and Visscher, 1994), demonstrated that 'associations of palynomorphs, palynodebris and diffuse organic aggregates are mainly composed of terrigenous and zooplanktonic constituents'. Organic remains of phytoplankton and benthos attributed a subordinate role in the study area.

Pollen analysis on box-core sediment form the south-eastern Indonesian waters were presented by S. Van der Kaars (2001). The author described general trends in pollen transport and indicated that pollen and, at a lower rate, Pteridophyta spore tend to decrease with increasing distance from the shore line. Despite the complex nature of vegetation and pollen transport in the region patterns, it was evidenced during the research, that the onshore distribution of individual taxa and major vegetation types are well reflected in marine sediments. Low values of mangroves were indicated as 
their values within the source area tend to decrease with distance to shore (Muller, 1959; Hooghiemstra et al., 1986; Sun et al., 1999; van der Kaars et al 2000, 2001; Sun et al., 2002). In our studies (Chapter 2) we described the similar trend.

\subsection{Studies on dinocysts}

Within the SE Asian region, a number of studies exists that dill with the composition of dinocyst assemblages in marine surface sediments. Some publications are available from the northern part of the Philippine Sea (Matsuoka, 1981), Bay of Bengal (Kumar, 1996), Manila Bay, the Philippines (Azanza, 2004), coastal waters of Sabah, Malaysia (Furio et al., 2006) along transect in oligotrophic tropical waters of the South China Sea (Kawamura, 2004).

In Indonesia, a number of studies on dinocysts are limited to only three studies. The investigation of in surface sediments of Jakarta Bay (Matsuoka et al., 1999) focused mainly on the patterns of the red tide dinoflagellates. The study on the stratigraphic distribution of dinocysts in the Tertiary of Indonesia, described two Oligocene surface sections in West Java. The first is the Batuasih Formation located near Cibadak, and the second is a section close to Padalarang where dinocysts were 'abundant in phosphatic nodules, but are heavily affected by thermal metamorphism, past overheating of the section, in the claystones and sandstones' (Morgenroth et al., 2011).

The most modern study was focused on the relationship between the spatial distribution of dinocysts and modern local environmental conditions (e.g. SST, SSS and productivity) in the eastern Indian Ocean (Hessler et. al., 2013). According to the composition of dinocysts, three environmental and oceanographic regions were described as a result of the last study. The first region located in western and eastern Indonesia and controlled by high SST and a low nutrient content of the surface waters. The second, Indonesian Throughflow (ITF) region, is dominated by heterotrophic dinocyst species reflecting the region's high productivity. The third region is located offshore north-west and west Australia which is characterized by low STT, high SSS and high oxygen content in the water.

\subsection{References}

Abram, N.J., McGregor, H.V., Gagan, M.K., Hantoro, W.S., Suwargadi, B.W., 2009. Oscillations in the southern extent of the Indo-Pacific Warm Pool during the mid-Holocene. Quaternary Science Reviews 28, 2794-2803.

Azanza, R.V., Siringan, F.P., San Diego-Mcglone, M.L., Yniguez, A.T., Macalalad, N.H., Zamora, P.B., Agustin, M.B., Matsuoka, K., 2004. Horizontal dinoflagellate cyst distribution, sediment characteristics and benthic flux in Manila Bay, Philippines. Phycological Research 52, 376-386. 
Barmawidjaja, B.M., Rohling, E.J., Van der Kaars, S.A., Vergnaud Grazzini, C., Zachariasse, W.J., 1993. Glacial conditions of the northern Molucca Sea region (Indonesia). Palaeogeography, Palaeoclimatology, Palaeoecology 101, 147-167.

Beaufort, L., de Garidel-Thoron, T., Linsley, B., Oppo, D., Buchet, N., 2003. Biomass burning and oceanic primary production estimates in the Sulu Sea area over the last $380 \mathrm{kyr}$ and the East Asian monsoon dynamics. Marine Geology 201, 53-65.

Beaufort, L., Van der Kaars, S., Bassinot, F.C., Moron, V., 2010. Past dynamics of the Australian monsoon: precession, phase and links to the global monsoon concept. Climate of the Past, 695706.

Cobb, K.M., Charles, C.D., Cheng, H., Edwards, R.L., 2003. El Niño/Southern Oscillation and tropical Pacific climate during the last millennium. Nature 424, 271-276.

Furio, E.F., Matsuoka, K., Mizushima, K., Baula, I., Chan, K.W., Puyong, A., Srivilai, D., Sidharta, B.R., Fukuyo, Y., 2006. Assemblage and geographical distribution of dinoflagellate cysts in surface sediments of coastal waters of Sabah, Malaysia. Coastal Marine Science 30 (1), 62-73.

Gagan, M.K., Ayliffe, L.K., Hopley, D., Cali, J.A., Mortimer, G.E., Chappell, J., McCulloch, M.T., Head, M.J., 1998. Temperature and surface-ocean water balanceof the mid-Holocene tropical western Pacific. Science 279, 1014-1018.

Gagan, M.K., Hendy, E.J., Haberle, S.G., Hantoro, W.S., 2004. Post-glacial evolution of the Indo-Pacific Warm Pool and the El Niño-Southern oscillation. Quaternary International 118-119, 127-143.

Ganssen, G., Troelstra, S.R., Fabar, B., Van der Kraas, S., Situmorang, M., 1989. Lata Quartenary palaeoceanography of the Banda Sea, Eastern Indonesian Piston cores (SNELLIUS-II Expedition, cruise G5). Netherlands Journal of Sea Research 24 (4), 491-494.

Grindrod, J., Moss, P., Van der Kaars, S., 1999. Late Quaternary cycles of mangrove development and decline on the north Australian continental shelf. Journal of Quaternary Science 14, 465-470.

Grindrod, J., Moss, P.T., van der Kaars, S., 2002. Late Quaternary mangrove pollen records from the continental shelf and deep ocean cores in the north Australian region. In: Kershaw, A.P., David, B., Tapper, T., Penny, D., Brown, J. (Eds.), Bridging Wallace's Lines e the Environmental and Cultural History and Dynamics of the SE-Asian-Australian Region. Advances in Geoecology, vol. 34. Cantena Verlag. Reiskirchen, Germany, 119-148.

Haberle, S.G., 2005. A 23 000-yr record from Lake Euramoo, Wet Tropics of NE Queensland, Australia. Quaternary Research 64, 343-356.

Hessler, I., Young, M., Holzwarth, U., Mohtadi, M., Lückge, A., Behling, H., 2013. Imprint of eastern Indian Ocean surface oceanography on modern organic-walled dinoflagellate cyst assemblages. Marine Micropaleontology, 101, 89-105.

Hooghiemstra, H., Agwu, C.O.C., 1986. Distribution of palynomorphs in marine sediments: a record for seasonal wind patterns over NW Africa and adjacent Atlantic. Geologische Rundschau 75, 8195.

Kawamura, H., 2004. Dinoflagellate cyst distribution along a shelf to slope transect of an oligotrophic tropical sea (Sunda Shelf, South China Sea). Phycological Research 52, 355-375.

Kumar, A., 1996. Palynology and palynofacies of recent marine sediments of the western flank of the Andaman Islands, Bay of Bengal. Geophytology 26 (1), 119-123.

Matsuoka, K., 1981. Dinoflagellate cysts and pollen in pelagic sediments of the northern part of the Philippine Sea. Bulletin of Faculty of Liberal Arts, Nagasaki University 21 (2), 59-70.

Matsuoka, K., Fukuyo, Y., Praseno, D.P., Adnan, Q., Masaki, K., 1999. Dinoflagellate cysts in surface sediments of Jakarta Bay, off Ujung Pandang and Larantuka of Flores Islands, Indonesia, with special reference of Pyrodinium bahamense. Bulletin of the Faculty of Fisheries 80, 49-56.

McGregor, H.V., Gagan, M.K., 2004. Western Pacific coral d180 record of anomalous Holocene variability in the El Niño-Southern Oscillation. Geophysical Research Letters 31, L11204. http://dx.doi.org/10.1029/2004GL019972.

Morgenroth, P., Rahardjo, A.T., Maryunani, K.A., 2011. Dinoflagellate cysts from two Oligocene surface sections on Java Island, Indonesia. Palaeontographica, 284 (4-6), 125-157. 
Moss, P.T., Cosgrove, R., Ferrier, A., Haberle, S., 2012. Holocene environments of the schlerophyll woodlands of the Wet Tropics of northeastern Australia. In: Haberle, S.G., David, B. (Eds.), Peopled Landscapes. Archaeological and Biogeographic Approaches to Landscapes. Terra Australis, 34. ANU ePress, Canberra Australia, 329-341.

Muller, J., 1959. Palynology of Recent Orinoco delta and shelf sediments: Reports of the Orinoco Shelf Expedition, Vol. 5. Marine Micropaleontology 5, 1-32.

Reeves, O.M., Bostock, H.C., Ayliffe, L.K., Barrows, T.T., De Deckker, P., Devriendt, L.S., Dunbar, G.B., Drysdale, R.N., Fitzsimmons, K.E., Gagan, M.K., Griffiths, M.L., Haberle, S.G., Jansen, J.D., Krause, C., Lewis, S., McGregor, H.V., Mooney, S.D., Moss, P., Nanson, G.N., 2013. Palaeoenvironmental change in tropical Australasia over the last 30,000 years - a synthesis by the OZ-INTIMATE group. Quaternary Science Reviews 74, 21-34.

Stott, L., Cannariato, K., Thunell, R., Haug, G.H., Koutavas, A., Lund, S., 2004. Decline of surface temperature and salinity in the western tropical Pacific Ocean in the Holocene epoch. Nature 431, 56-59.

Sun, X.J, Li, X., Beug, H., 1999. Pollen distribution in hemipelagic surface sediments of the South China Sea and its relation to modern vegeta-tion distribution. Marine Geology 156, 221-226.

Sun, X.J., Luo, Y. L., Huang, F., 2003. Deep-sea pollen from the South China Sea: Pleistocene indicators of East Asian monsoon. Marine Geology 201, 97-118.

Sun, X.-J., Li, X., Luo, Yu.-L., 2002. Vegetation and climate on the Sunda Shelf of the South China Sea during the Last Glaciation - Pollen results from station 17962. Acta Botanica Sinica 44 (6), 746752.

Tudhope, A.W., Chilcott, C.P., McCulloch, M.T., Cook, E.R., Chappell, J., Ellam, R.M., Lea, D.W., Lough, J.M., Shimmield, G.B., 2001. Variability in the El Nino-Southern Oscillation through the glacialeinterglacial cycle. Science 291, 1511-1517.

Van der Kaars, S., 1991. Palynology of eastern Indonesian martine piston-core: a late Quaternary vegetational and climatic record for Austral-asia. Palaeogeography, Palaeoclimatology, Palaeoecology 85, 239-302.

Van der Kaars, S., 1998. Marine and terrestrial pollen records of the last glacial cycle from the Indonesian region: Bandung basin and Banda Sea. Palaeoclimates: Data Modelling 3, 209-219.

Van der Kaars, S., 2001. Pollen distribution in marine sediments from the south-eastern Indonesian waters. Palaeogeography, Palaeoclimatology, Palaeoecology 171, 341-361.

Van der Kaars, S., Wang, X., Kershaw, A.P., Guichard, F., Setiabudi, D.A., 2000. A Late Quaternary palaeoecological record from the Banda Sea, Indonesia: patterns of vegetation, climate and biomass burning in Indonesia and northern Australia. Palaeogeography, Palaeoclimatology, Palaeoecology 155, 135-153.

Van Waveren, I.M., 1989. Palynofacies analysis of surface sediments from the northeastern Banda Sea (Indonesia). Netherlands Journal of Sea Research 24 (4), 501-509.

Van Waveren, I., Visscher, H., 1994. Analysis of the composition and selective preservation of organic matter in surficial deep-sea sediments from a high-productivity area (Banda Sea, Indonesia). Palaeogeography, Palaeoclimatology, Palaeoecology 112, 85-111.

Wang, X.M., Sun, X.J., Wang, P.X., Stattegger, K., 2007. A high-resolution history of vegetation and climate history on Sunda Shelf since the last glaciation. Science China. Series D-Earth Science 50 (1), 75-80. 


\title{
CHAPTER 3
}

\section{Eleven Month High Resolution Pollen and Spore Sedimentation Record off SW Java in the Indian Ocean}

\author{
Anastasia Poliakova ${ }^{1^{*}}, \operatorname{Tim}_{\text {Rixen }}{ }^{2}$, Tim Jennerjahn $^{2}$, Hermann Behling ${ }^{1}$
}

(1) Georg-August-University, Albrecht-von-Haller-Institute for Plant Sciences, Department of Palynology and Climate Dynamics, Untere Karspüle 2, 37073 Göttingen, Germany.

(2) Leibniz Center for Tropical Marine Ecology, Fahrenheitstrasse 6, 28359 Bremen, Germany

Marine Micropaleontology: 111 (2014) 90-99; http://dx.doi.org/10.1016/j.marmicro.2014.06.006

Key words: pollen analysis, modern oceanic pollen and spore deposition, vegetation, marine sediment trap, SW Java. 


\section{Abstract}

Settling particles collected in a sediment trap $60 \mathrm{~km}$ off SW Java in the Indian Ocean at a 2200m deep site, about $830 \mathrm{~m}$ above the sea floor, between December 2001 and November 2002 (intervals of 16 days for 11 months) were analyzed for the abundance and taxa composition of pollen and spores. Several factors control their deposition such as the monsoon-driven reversal of the wind directions and ocean currents as well as flowering periods. Long distance transport plays a particular role during the monsoon seasons. During the NW monsoon (mid-December-beginning of March), maxima of Picea type, Alnus, Pinus and Quercus pollen occur in the trap samples, which correspond to wind and marine currents coming from the north, probably the Equatorial Counter Current and Southern Java Current, transporting pollen from the southern part of continental Asia and Sumatra to the research area. During the SE monsoon (end of July-mid-November), an increase of pollen originating from southeast Indonesia and Australia was observed. Pollen grains were probably transported by the South Equatorial Current and partly by the Leeuwin Current. Casuarina and, in part, Eucalyptus are most abundant during this period. During the intermonsoon period, assemblages are mainly composed of pollen originating from West Java. Maxima of some pollen taxa, such as Elaeocarpus, Myrica, Dacrycarpus type, Casuarina, Eucalyptus and Podocarpus type probably reflect their flowering periods. The transportation time from the pollen source area to the sediment trap is about 1-2 months. The extrapolated pollen accumulation rate of the marine sediment trap would be about 1670 grains $/ \mathrm{cm}^{2} / \mathrm{yr}$. The trap collected low concentrations of mangrove pollen, which might be the result of the strong destruction of the mangrove belt in Java during recent decades. High values of Poaceae pollen are probably related to the land use, forest canopy opening and development of the secondary vegetation in West Java. The majority of the pollen and spores collected by the sediment trap reflects the vegetation of SW Java, but long distance transport, in particular by the marine currents during the SE and NE monsoons, needs to be considered when interpreting marine pollen records off SW Java in the eastern Indian Ocean.

\subsection{Introduction}

In order to better understand and interpret marine fossil pollen records, studies on modern pollen and spore transportation and deposition in the ocean are needed. Sedimentary pollen records can provide crucial information on vegetation, human impact and climate change as well as on past changes of ocean circulation. In particular, these studies can help in understanding seasonal variations of modern pollen distribution patterns related to plant-specific factors such as source vegetation distribution and flowering periods as well as transport specific factors, e.g. winds and ocean currents. Valuable data can be obtained from the sediment trap studies.

Several papers have been published on the palaeovegetation and palaeoecology of the Java region including terrestrial (e.g. Polhaupessy, 1980, 1981; Semah, 1984; Stuijts, 1984, 1993; Stuijts et al., 1988; van der Kaars and Dam, 1995, 1997; Wang, et al., 1999; Pudjoarinto and Cushing, 2001; van der Kaars and De Deckker, 2002; Van der Kaars and van den Bergh, 2004; Yulianto et al., 2005) and marine archives (e.g. van der Kaars, 1991, 1998; Van der Kaars et al., 2000; Van der Kaars, 2001; Sun et al., 2002; Kershaw et al., 2011). Studies on modern pollen sedimentation are rare for the Indonesian region (Stuijts, 1993; Beuning, 1996; Buschman et al., 2011). Data on modern pollen distribution in marine sediments are available from the South China Sea (Sun et al., 1999), the Banda Sea and Seram Sea (Van Waveren, 1989; van der Kaars, 1998) and from waters of eastern Indonesia 
(van der Kaars, 1991). A number of publications on continuous sediment trap series in the Indian Ocean waters are available (e.g. Rixen et al., 2006a, 2006b; Mohtadi et al., 2009; Romero et al., 2009). However, no studies on pollen assemblages in sediment trap recordings have been carried out for Indonesia. For the first time, studies on pollen and spores from a sediment trap off SW Java are presented in this paper.

The main objectives of this study are to compare the abundance and composition of pollen deposited in the deep Indian Ocean margin under different monsoon conditions during an 11 months period, and to identify the factors that can influence temporal changes in pollen assemblage composition. This study also provides knowledge on the seasonal patterns of pollen and spore sources, fluxes and composition.

\subsection{Environmental setting}

\subsubsection{Study region}

The site of the sediment trap $\left(8^{\circ} 17.5^{\prime} \mathrm{S}, 108^{\circ} 02.0^{\prime} \mathrm{E}\right)$ is located in the eastern part of the Indian Ocean, $60 \mathrm{~km}$ south off SW Java, Indonesia (Fig. 3.1). Bathymetric data suggest that sea bottom morphology of the study area is characterized by many submarine canyons cutting the shelf and extending down into the deeper parts of the basin. The landward flank of the fore arc basin off Java forms a smooth slope. The outer-arc ridge is 2000-3000mdeep, with isolated highs of approximately $1000 \mathrm{~m}$ (Moore et al., 1980).

On Java, two large mountain chains are found up to 3200 mhigh. The island's main rivers flowing into the Indian Ocean are the Cimandiri, Cibuni, Ciwulan, Citanduy, Serayu, Progo and Opak (Whitten et al., 1996).

\subsubsection{Marine currents}

The ocean currents in the study area move according to the seasonal wind regime (e.g. Wijffels et al., 1996, 2002). During the NW monsoon season (mid-December-beginning of March, Fig. 3.1A) the South Java Current (SJC), derived from the Indian Ocean Equatorial Countercurrent (ECC), moves towards the southeast to meet the saline waters of the Leeuwin Current (LC), which originates in the eastern part of the Indonesian Archipelago (Tomczak and Godfrey, 1994). The mixing of the SJC and the LC produces the South Equatorial Current (SEC), which then moves further westward. During the SE monsoon season (end of July-mid-November, Fig. 3.1B), the SJC takes an opposite direction, flowing northwestward and feeding the SEC without a significant contribution of the LC. The high precipitation rates during this season lead to an increased run-off from Sumatra and Java. The Indonesian region is "a key area along the return branch of the global conveyor belt and the only low-latitude pathway between two ocean basins", with major climatic importance on a global scale (e.g. Gordon, 2005).

\subsubsection{Climate}

According to the Koppen-Geiger classification, the climate in the study region is tropical: hot and humid. The climate is dominated by the monsoon circulation (Whitten et al., 1996). During the austral summer (December-April), the NW winds transport large masses of moist air from the Asian high-pressure belt, which causes heavy rains on the archipelago. The annual precipitation ranges from 1500-2000 mm in the lowland up to $6000 \mathrm{~mm}$ on the upper slopes of the central mountains of 

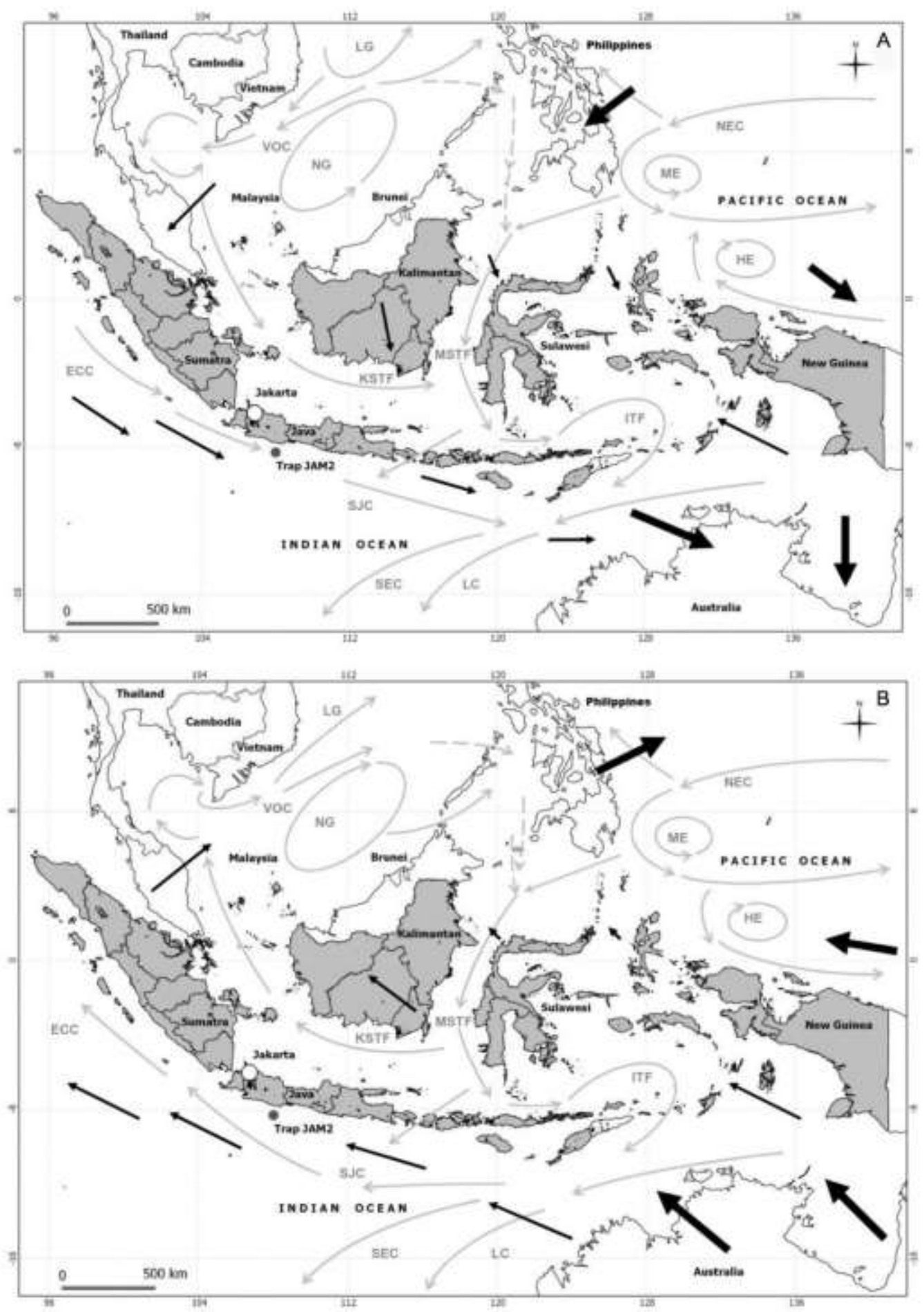

Fig. 3.1. Schematic map showing main oceanic currents and winds in the study area during the (January) southern summer (NW monsoon) and (July) southern winter (SE monsoon) with the position of the sediment trap JAM2 off SW Java (dark-grey dot). Wind patterns according to Wyrtki, 1957; Black (2002) and Wang et al. (2000, 2005); directions of currents are modified after Schott, McCreary (2001); Zheng et al. (2006); Fang et al. (2009). The abbreviations stand for the following: ITF, Indonesian Throughflow; HE, Halmahera Eddy; ECC, Equatorial Counter Current; KSTF, Karimata Strait Throughflow; LC, Leeuwin Current; LG, Luzon Gyre; ME, Mindanao Eddy; MSTF, Makassar Strait Throughflow; NEC, North Equatorial Current; NG, Nansha Gyre; SEC, South Equatorial Current; SJC, Southern Java Current; VOC, Vietnam Offshore Current. Dashed arrows show temporal flows. 
West Java (Sijatauw, 1973; Whitten et al., 1996). During the austral winter (June-October) dry and cool winds are predominating. The precipitation during the SE monsoon is relatively low. The rainfall distribution in the western part of Java has a strong south-north gradient, from more than $3000 \mathrm{~mm}$ to about 1000-1500 mm per year (Richards, 1952; Sijatauw, 1973; Monk et al., 1997). The rate of precipitation is strongly influenced by the El Niňo Southern Oscillation (ENSO), with its two extreme phases, El Niňo and La Niňa, which respectively lead to low and high precipitation rates over Indonesia (Ropelewski and Halpert, 1987).

\subsubsection{Vegetation}

The vegetation of Indonesia (Fig. 3.2) includes mangroves, lowland forest and submontane/mountain forest (Burbidge, 1960; Flenley, 1979; Van Steenis, 1984; Collins et al., 1991; Whitten et al., 1996). The natural forests in the lowlands are composed of extensive evergreen and semi-evergreen rainforests as well as moist deciduous and dry deciduous forests. Differences are mostly related to the seasonality of rainfall. There are also small areas of azonal limestone and freshwater swamp forests. The original lowland vegetation has been heavily changed by humans during the last few hundred years. Large areas of the lowlands have been cultivated for rice, palm plantations and have been partly changed to aquaculture ponds. In the areas of secondary forest Elaeocarpus (Elaeocarpaceae), Moraceae and a variable number of re-growth taxa occur (Whitten et al., 1996) such as Acalypha (Euphorbiaceae), Ficus (Moraceae), Macaranga/Mallotus (Euphorbiaceae), Trema (Cannabaceae), Pandanus (Pandanaceae) and others (Van Steenis, 1984; Whitmore, 1984).

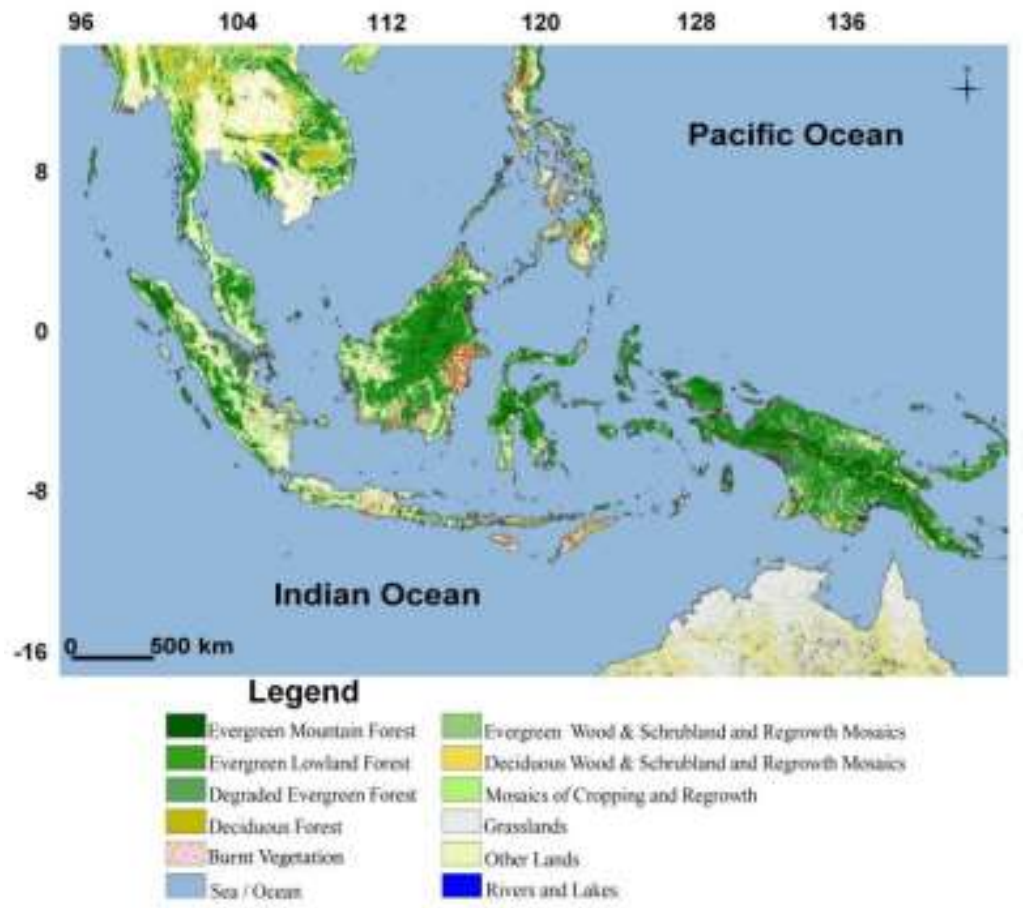

Fig. 3.2. Main vegetation types of Indonesia. Modified after http://bioval.jrc.ec.europa.eu (Continental Southeast Asia Forest cover map, 1998-2000 and Insular Southeast Asia - Forest Cover Map, 1998-2000; Stibig and Malingreau, 2003; Stibig et al., 2003, 2004).

Starting at 1000-1500 m elevation, submontane forest occurs, which is dominated by Castanopsis, Quercus (Fagaceae) and Lauraceae. At higher elevations (1500-1800 m) it changes to mountain forest, which is characterized by a distinct vertical zonation rich in ground flora and with an important role of coniferous trees (e.g. Dacrycarpus and Podocarpus), as well as Engelhardia (Juglandaceae), Myrica (Myricaceae), Weinmannia (Cunoniaceae), Myrsinaceae, Ericaceae and others (e.g. Van Steenis, 1984; Van der Kaars and Dam, 1995). Due to excessive land use, only a few remote 
spots of natural plant communities have remained in Java and, in general, only the tops of mountains still bear original vegetation (Stuijts, 1993).

The area of mangroves on Java has been highly reduced as well (Collins et al., 1991; Hutomo and Moosa, 2005; Food and Agricultural Organisation, FAO Report, 2007). The remaining pockets of mangroves can be found along the coast of South and Northwest Java (Whitten et al., 1996).

\subsection{Material and methods}

\subsubsection{Sediment trap}

Sediment trap JAM2 (ParfluxMark 7G-21, Honjo and Doherty, 1988) was deployed at $2200 \mathrm{~m}$ water depth; samples were collected between December 2001 and November 2002. The trap was located about $830 \mathrm{~m}$ above the seafloor. The sampling interval of the trap was 16 days (Table 3.1). Before installation, sample bottles were filled with seawater from $1800 \mathrm{~m}$ water depth. To prevent degradation of trapped material, mercury(II)-chloride $(3.3 \mathrm{~g} / \mathrm{l})$ was added to the cup water. Recovered samples were stored at $2-4{ }^{\circ} \mathrm{C}$.

\begin{tabular}{llll} 
Sample No. & Cups open & Cups close & $\begin{array}{l}\text { Monsoon } \\
\text { conditions }\end{array}$ \\
D1 & 14 Dec 2001 & 30 Dec 2001 & NW \\
D2 & 30 Dec 2001 & 15 Jan 2002 & NW \\
D3 & 15 Jan 2002 & 31 Jan 2002 & NW \\
D4 & 31 Jan 2002 & 16 Feb 2002 & NW \\
D5 & 16 Feb 2002 & 4 Mar 2002 & NW \\
\hline D6 & 4 Mar 2002 & 20 Mar 2002 & non \\
D7 & 20 Mar 2002 & 5 Apr 2002 & non \\
D8 & 5 Apr 2002 & 21 Apr 2002 & non \\
D9 & 21 Apr 2002 & 7 May 2002 & non \\
D10 & 7 May 2002 & 23 May 2002 & non \\
D11 & 23 May 2002 & 8 Jun 2002 & non \\
D12 & 8 Jun 2002 & 24 Jun 2002 & non \\
D13 & 24 Jun 2002 & 10 Jul 2002 & non \\
D14 & 10 Jul 2002 & 26 Jul 2002 & non \\
\hline D15 & 26 Jul 2002 & 11 Aug 2002 & SE \\
D16 & 11 Aug 2002 & 27 Aug 2002 & SE \\
D17 & 27 Aug 2002 & 12 Sep 2002 & SE \\
D18 & 12 Sep 2002 & 28 Sep 2002 & SE \\
D19 & 28 Sep 2002 & 14 Oct 2002 & SE \\
D20 & 14 Oct 2002 & 30 Oct 2002 & SE \\
D21 & 30 Oct 2002 & 15 Nov 2002 & SE \\
\hline
\end{tabular}

Table 3.1. Number of samples and sampling periods of trapped material off SW Java in the tropical SE Indian Ocean. The abbreviations indicate the following: NW - northwest monsoon; non (light-grey shading) intermonsoon period; SE (dark-grey shading), southeast monsoon.

\subsubsection{Pollen analysis}

Pollen analysis was undertaken on $25 \%$ of the collected material. Pollen was concentrated from the settling particle matrix by the method described by Faegri and Iversen (1975). Calcium carbonate was dissolved with hydrochloric acid ( $\mathrm{HCl} 10 \%$ ). Silicates were dissolved with hydrofluoric acid ( $\mathrm{HF} 72 \%$ ). The samples were sieved over a nylon filter to remove particles b10 $\mu \mathrm{m}$. The identification of pollen and spores was done using the department's reference collections including about 300 Indonesian 54 
taxa and with the help of palynological literature (e.g. Moore and Webb, 1978; Wang et al., 1995; Fujiki et al., 2005; Mao et al., 2012). Furthermore, the online database "The Australasian Pollen and Spore Atlas" (Weng et al., 2007) was used.

All identified pollen and spore types were photographed with a digital camera through an optical microscope. Photos of identified pollen and spores are available upon request at the Department of Palynology and Climate Dynamics (University of Göttingen, Germany). Samples were counted to a minimum of 100 pollen grains. Pollen and sporepercentages were calculated on the basis of a total pollen sum that excluded indeterminate pollen and Pteridophyta spores. To determine pollen accumulation rates (PAR) a Lycopodium tablet (Stockmarr, 1971) with a known number of spores $(20,848 \pm 1546)$ was added to each sample before processing. The PAR was calculated for each of the time intervals. The annual PAR was extrapolated and is based on the 11 months record.

Pollen taxa were grouped into the main vegetation types of West Java such as mangrove, lowland trees, montane trees (according to their most common source), herbs and Pteridophyta. Grouping was done according to Whitmore (1990) and Van der Kaars (2001). Pollen taxa that do not belong to the natural vegetation of West Java are summed up as "long distance component" (LDC) and were divided into two subgroups. The "northern" subgroup included pollen types typical for lower latitudes of the northern hemisphere (e.g. Alnus, Pinus, Picea, Quercus and Ulmus). The "southern" subgroup of pollen represents plants that are more characteristic for the Australian continent (i.e. Eucalyptus and Casuarina). Some of these pollen types may also originate from exotic taxa planted in West Java (e.g. Pinus, Alnus and Eucalyptus) or from locally grown taxa (e.g. Casuarina).

Relative pollen diagrams (Figs. 3.3 and 3.4) were prepared using TILIA software (Grimm, 1988). Local pollen zones have been established visually by comparing the temporal dynamics of the principal taxa, supported by the results of stratigraphically constrained cluster analysis by sum-of-squares using CONISS for TILIA (Grimm, 1987).

\subsection{Results}

In total, 21 trap samples were analyzed for pollen and spores. For each sample, the diagram shows the percentages of most common taxa (Fig. 3.3), vegetation groups, mean counts for pollen and spores, as well as the pollen accumulation rate (PAR) for 16 days (Fig. 3.4). Pollen and spore types with a minor contribution are not included in the diagram. In total, 64 pollen types and 17 Pteridophyta spore types were identified (see Appendix A). Trees and shrubs make up around $78 \%$ of pollen taxa (50 pollen types) while herbs account for the remaining $22 \%$ (14 pollen types). The PAR varies between 30 and 178 grains $/ \mathrm{cm}^{2} / 16$ days or between 2 and 11 grains $/ \mathrm{cm}^{2} /$ day. Average PAR is about 73.2 grains $/ \mathrm{cm}^{2} / 16$ days or about 4.5 grains $/ \mathrm{cm}^{2} /$ day. The extrapolated annual PAR is about 1670 grains $/ \mathrm{cm}^{2} / \mathrm{yr}$. Based on a cluster analysis, three groups of samples could be recognized, which succeed each other in time and reflect changing monsoon conditions as displayed in Table 3.1. Description of the groups is given below.

\subsubsection{Samples D1-D5 (December 14, 2001-March 4, 2002; NW monsoon period)}

Mangroves are only represented by Rhizophora ( 1\%, Fig. 3.3). The amount of lowland pollen taxa is high (on average $49 \%$ of the pollen sum), with Macaranga/Mallotus ( $18 \%)$ and Elaeocarpus (about $13 \%)$ being the dominant pollen types. Pollen of Acalypha contributes some $2 \%$. 


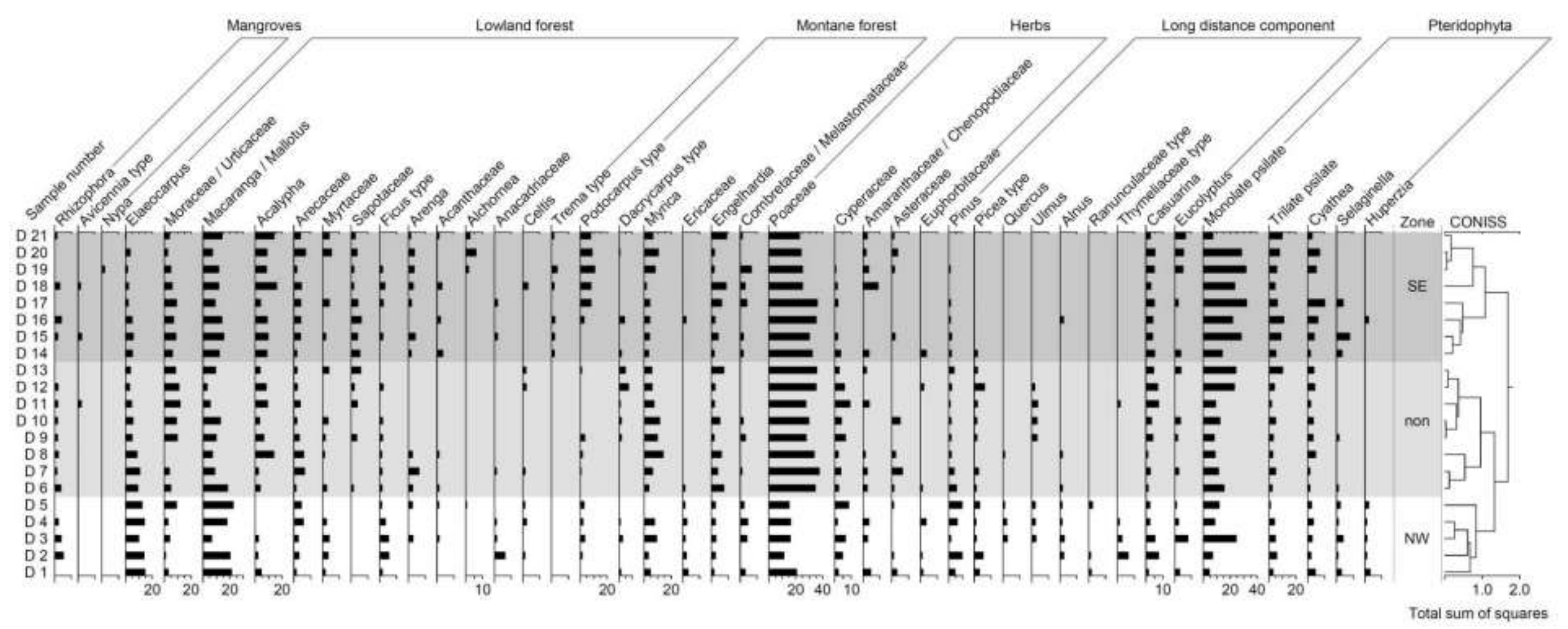

Fig. 3.3. Pollen diagram showing percentage of main pollen and spore types under changing monsoon conditions in the Indian Ocean off SW Java. 
Values of Moraceae/Urticaceae slightly increase at the end of the NW monsoon (mid-Februarybeginning of March). Arecaceae, Ficus type and Myrtaceae are constantly present. Montane taxa account for approximately $10 \%$, and are dominated by Myrica, Podocarpus type and Dacrycarpus type (Fig. 3.3). On average, herb pollen accounts for $23 \%$ and is composed of Poaceae ( $16 \%$ ), Cyperaceae ( $\sim \%)$ and Amaranthaceae/Chenopodiaceae ( $2 \%)$. The long distance component (LDC) amounts to $17 \%$ (from $10 \%$ to $24 \%$ ). The contribution of "northern" pollen types varies from $7 \%$ to $17 \%$ and is composed mainly of Pinus and the Picea type ( $\sim \%$ and $\sim 2 \%$, respectively) with some grains of Alnus, Quercus, Ulmus and Thymelaeaceae type. Pollen of Ranunculaceae type occurs only in this period. The portion of "southern" pollen types is about 3-9\% with average values of Casuarina of about 3\% and values of Eucalyptus of about 2\% (Fig. 3.3). Pteridophyta spores are not very frequent in this period, around 20\% (except sample D3 where ferns make up about $43 \%$ ). Mean values of Cyathea show minimum values ( $2 \%)$, while Huperzia spores with the same percentages have maximum values during this period. PAR is relatively low, between 45 and 98 grains $/ \mathrm{cm}^{2} / 16$ days with an average of 65 grains $/ \mathrm{cm}^{2} / 16$ days.

\subsubsection{Samples D6-D14 (March 4-July 10, 2002, intermonsoon period)}

Values of mangrove pollen remain at the same level. The pollen contribution of lowland trees decreases to about 37\% (Fig. 3.4) and the composition of taxa changes. Values of Elaeocarpus and Macaranga/Mallotus decrease to $\sim 6 \%$ and $\sim 9 \%$, respectively, while percentages of Moraceae/Urticaceae ( 7\%) and Acalypha ( 6\%) increase (Fig. 3.3). Arecaceae and Ficus type are common. Sapotaceae pollen occurs for the first time. Among the montane taxa (increase to 13\%), Myrica ( 8\%) dominates, Engelhardia and Dacrycarpus type are common and Ericaceae are absent. Herb pollen accounts for about $40 \%$, which is more than in the previous period. LDC stays at about $9 \%$ (from $4 \%$ to $13 \%$ ). The portion of "northern" pollen types amounts to $3-7 \%$. Pinus, Picea type and Ulmus pollen are common whereas Alnus, Quercus and the Thymelaeaceae type are represented by single grains. Ranunculaceae are not found. The contribution of "southern" pollen types is about $1-7 \%$ (Casuarina mainly). Average Pteridophyta spore values are slightly higher ( $28 \%$, Fig. 3.3) than during the NW monsoon while Selaginella spores decrease markedly and Huperzia is absent. The PAR varies between 47 and 178 grains $/ \mathrm{cm}^{2} / 16$ days with an average of about 107 grains $/ \mathrm{cm}^{2} / 16$ days, which is much more than in the previous period.

\subsubsection{Samples D15-D21 (July 10-November 15, 2002, SE monsoon period)}

Mangrove pollen remains at same low values, about $1 \%$ of the pollen sum (Fig. 3.4). The value of lowland tree pollen is around $45 \%$. The group is composed mainly of Macaranga/Mallotus ( 12\%) and Acalypha ( $10 \%$ ) pollen (Fig. 3.3). Pollen percentages of Elaeocarpus ( 3\%) and Moraceae/Urticaceae ( $6 \%)$ are lower. Arecaceae are frequent. Pollen of the Alchornea type occurs in the samples D19-D21 (Fig. 3.3). Values of montane taxa are about 14\%. Percentages of the Podocarpus type strongly increase ( $\sim 6 \%$ ), while those of Myrica decrease ( $\sim 5 \%)$. Percentages of almost all herb taxa decrease, except for Poaceae, which remain stable, while Amaranthaceae/Chenopodiaceae increase. The mean value for herb pollen is about $33 \%$. LDC occurs at slightly lower amounts (from 3\% to $10 \%$ with the average of about 7\%), and only 5 out of 9 taxa are found. The portion of "northern" pollen types amounts to about 1\% (Fig. 3.3). Pinus is frequent at the beginning of the period (samples D14-D17) but is not found at the end of the SE monsoon 
(samples D20-D21). The Picea type and Alnus are represented by single grains only. The contribution of "southern" pollen types is about $3-8 \%$. Values of Casuarina pollen are $~ 4 \%$, and Eucalyptus accounts to $\sim 2 \%$. Pteridophyta spores reach their maximum value of about $42 \%$. PAR decreases to an average of 43 grains $/ \mathrm{cm}^{2} / 16$ days and varies between 30 and 69 grains $/ \mathrm{cm}^{2} / 16$ days.

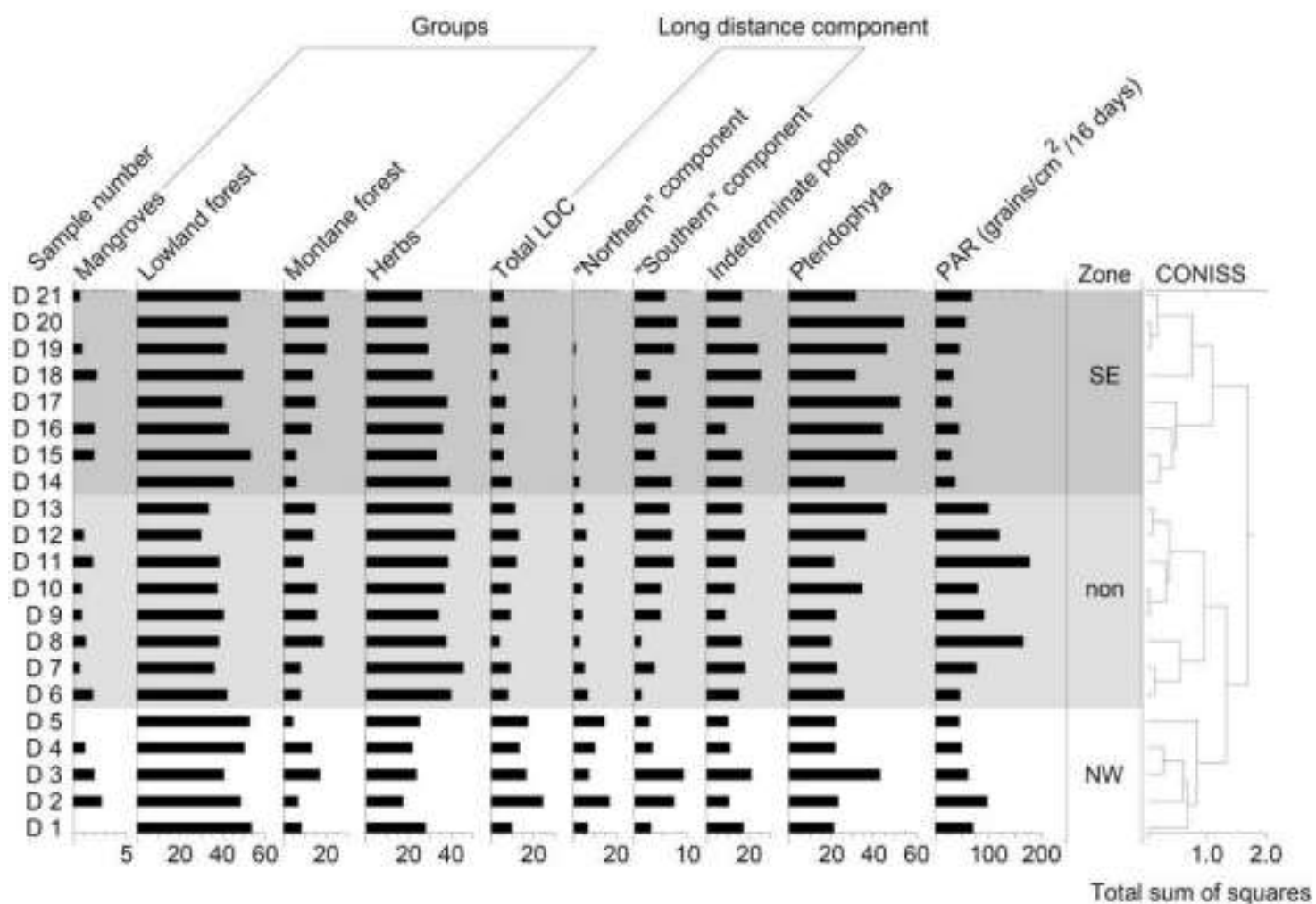

Fig. 3.4. Diagram showing pollen percentages of mangroves, lowland and montane trees, herbs, long distance component (LDC), indeterminate pollen sum as well as Pteridophyta sum and pollen accumulation rate (PAR) under changing monsoon conditions in the Indian Ocean off SW Java. The abbreviations indicate the following: NW-northwest monsoon; non (light-gray shading) intermonsoon period; SE (dark-gray shading) - southeast monsoon.

\subsection{Interpretation and discussion}

\subsubsection{Factors controlling pollen dispersal in the ocean}

Several factors need to be considered for interpreting the pollen and spore assemblages deposited in the sediment trap off SW Java, such as the pollen source area, flowering periods, distance to the pollen producing vegetation, river discharge, wind fields, marine currents and the time for pollen and spore transportation. Throughout the whole recorded period, the pollen and spore spectra generally reflect the vegetation of SW Java well. The lowland forest is represented by pollen of Elaeocarpus, Moraceae/Urticaceae, Sapotaceae, Myrtaceae, Alchornea and others. High values of re-growth taxa (e.g. Macaranga/Mallotus, Acalypha, Ficus and Trema) point to the wide occurrence of secondary forest. Montane forest is represented by Podocarpus, Dacrycarpus, Myrica, Engelhardia and Ericaceae. 
Relatively frequent Arecaceae pollen and Arenga occur in the trap samples, reflecting the imprint of palm plantations, which have increased markedly in Java during the last few decades (e.g. Whitten et al., 1996). This signal evidence for the forest disturbance as it has been shown for Rawa Danau (West Java) where land clearance and cultivation of crops from around AD $1770 \pm 80$ was indicated by a markedly higher abundance of Arenga and Cocos nucifera pollen and an increased charcoal to pollen ratio (Van der Kaars and van den Bergh, 2004). For Danau Padang (West Java), Stuijts (1993) referred to the marked decline in pollen of forest taxa (e.g. Altingia, Castanopsis, Nauclea) that occurred after ca. 2500 BP. During approximately the same time she pointed to the findings of Arenga pollen as a possible indicator of the sugar palm cultivation.

High values of Poaceae pollen are probably also related to land use and to the formation of open grasslands in SW Java. It is conceivable that both winds from the land to the ocean and the discharge by several rivers of SW Java (in particular, the Ciwulan, Citanduy and Serayu) contribute to pollen and spore deposition in the trap. The same assumption was made by Sun et al. (2002), who suggested that herbaceous pollen taxa may extend their distribution patterns into the Southern China Sea due to the combined effects of wind, marine currents and rivers.

In our record, mangrove vegetation is reflected mainly by Rhizophora pollen. The values of mangroves are low. The same was reported by van der Kaars (2001) for marine surface samples from southern Indonesia which contained less than $5 \%$ of mangrove pollen, while mangroves were represented by 2-3 times higher values (about 10 to 15\%) in samples obtained close to the coast of New Guinea and to the north of Lombok, Sumbava and Flores. In marine core samples from the late Holocene, Rhizophoraceae contributes about 12 to $20 \%$ of the pollen and spore sum on the Sunda Shelf (Sun et al., 2002).

Mangrove taxa often show the highest values within their source area (Muller, 1959; Hooghiemstra et al., 1986; Sun et al., 1999) with decreasing values with distance from shore (van der Kaars, 2001; Sun et al., 2002). The low percentages of mangrove pollen in our data could be the result of the excessive destruction of the mangrove belt in Java during the last few decades. For comparison, in 1981 the area of mangroves on Java was reported to occupy about $500 \mathrm{~km}^{2}$ (Choong et al., 1990; Sukardjo, 1990), by 2000 it had declined to about $293 \mathrm{~km}^{2}$ (Food and Agricultural Organisation, FAO Report, 2010).

Fern spores are relatively frequent in the record and are likely linked to river discharge, as Pteridophyta grow mainly under moist conditions. Van Waveren (1989) and Dai and Weng (2011) indicate that it is hardly possible for fern spores to travel by air over long distances, as it is difficult for the wind to take them from the wet soil, while water can easily wash them out.

\subsubsection{Seasonal variation in pollen fluxes and composition}

\subsubsection{NW monsoon (December 14, 2001-March 4, 2002)}

Pollen from exotic plants such as Picea, Alnus, Pinus and Quercus contributes up to $17 \%$ to the total pollen assemblage and has apparently been transported over a long distance. Picea and Alnus pollen do not occur naturally south of $20^{\circ} \mathrm{N}$ in Asia (Muller, 1972; Whitmore, 1984). The closest regions where these trees grow naturally lie within the Malay Peninsula, Thailand, Cambodia and South China (Fig. 3.2). A few trees of Alnus have been cultivated in the mountainous regions of West Java as a garden ornamental or in trails by the Forestry Service (Backer and van den Brink, 1965). Only the occasional Alnus pollen is known from palaeoecological records in East Java (Beuning, 1996) and from 
higher elevated sites in West Java (Stuijts, 1993). Therefore, it can be assumed that most of the deposited Alnus pollen are transported over a long distance from continental Asia.

Pollen of Pinus can originate both from continental Asia highlands and from montane and submontane pine plantations of Sumatra and Java. Plantations of Pinus have existed since 1935; pine trees have been used for reforestation and wood production (Backer and van den Brink, 1965; Whitten et al., 1996). Despite the fact that pine trees are not indigenous in Java, both in studies of modern pollen rain and in lake surface sediment samples from West Java and Sumatra, pollen of Pinus was regularly found (Stuijts, 1993). In the marine realm they can be observed close to areas where pine trees have never been planted or grow naturally, e.g. in hemipelagic surface sediments north of Borneo, where Sun et al. (1999) reported more than $20 \%$ pine pollen of the pollen and spore sum. Pinus is known to be a prolific pollen producer. Additionally, its vesiculate pollen grains can easily get translocated by aeolian and fluvial transport (Heusser, 1988; Heusser and Balsam, 1977). It is therefore difficult to interpret the origin of the Pinus pollen in the sediment trap, but taking into account all the above mentioned points, we hypothesize that most of it was also transported over a long distance. This is supported by the fact that higher amounts of pine pollen were collected during the NW monsoon compared to the following periods when the winds from the north were almost absent.

Quercus is not indigenous in Java (Whitten et al., 1996). Pollen of the oak tree may come, in particular, from the mountains of Sumatra, where Quercus is native. Some pollen grains may also be transported from continental Asia, but this amount can be expected to be low as the distance between the sediment trap and its pollen source area is relatively large. Ulmus is considered in the literature (Backer and van den Brink, 1965) as not indigenous in Java as well. Nevertheless, the pollen of Ulmus was found in studies of the modern pollen rain in West Java (Stuijts, 1993) and from Sumatra (Maloney, 1985).

We assume that pollen of exotic plants is mainly transported from continental Asia by trade winds and/or to some extent by marine currents such as the Equatorial Counter Current and Southern Java Current (Fig. 3.1).

Apart from information about transport ways, comparing the occurrence of pollen of region specific plants in the traps with their flowering time can provide information about the transport duration. We found high values of Elaeocarpus pollen during the NW monsoon period that can be related to its flowering season (from October to December, Table 3.2). The calculated delay between the maximum tree bloom and the maximum accumulation of Elaeocarpus pollen in the trap suggests a transportation time of about one month.

\subsubsection{Intermonsoon period (March 4-July 10, 2002)}

During the intermonsoon period, pollen assemblages are mainly composed of regionally produced pollen. Wind masses and marine currents from NW influence the region much less at this time. This is reflected by a lower amount of pollen of the "northern" taxa such as Alnus, Pinus and Picea in the trap samples. The pollen percentage of Pinus in this period is two times lower (3\%) compared to the NW monsoon season (6\%) and is considered to be mostly of regional origin, probably from the highlands of SW Java. Maxima of Myrica pollen in April-beginning of June and maxima of Dacrycarpus in June-July correlate with the flowering periods of these trees in Java (Table 3.2). About 1 to 2 months delay is noticed between flowering time and pollen accumulation in the sediment trap. PAR increases in April (sample D8) and at the end of May-beginning of June (sample D11). The increased 
amount of fern spores at the end of June-beginning of July (sample D13) could be a consequence of the increased rainfall and associated high river discharges during the late NW monsoon season (Milliman et al., 1999; Rixen et al., 2006a, 2006b).

According to the wind regime, the intermonsoon period lasts until the end of July and the next sample (D14, July 10-26) should be included in this period, as it has been done by Mohtadi et al. (2009). However, the composition of the pollen assemblages and the results of constrained cluster analysis suggest that it belongs to the next pollen zone.

Table 3.2. Flowering periods of selected taxa in Southeast Asia and Australia.
Taxa

Casuarina

Dacrycarpus

Elaeocarpus

Eucalyptus

Myrica

Podocarpus
Flowering period

In Australia April - June, Casuarina equisetifolia February - April and September - October

In Thailand January - May

2-3 times a year, often after dry season, November - January, in Malaysia August October and March - May In Indonesia all months, Eucalyptus urophylla during the rainy season. In Australia most species March - April (often till June)

In Java March - May, in Sulawesi and in Australia May - June and October November

In Java October - December

\section{Reference}

Morton (1980)

Lemmens et al. (1995)

Sosef et al.(1998);

Boomsma(1972)

Soerianegara and Lemmens (1993)

Lemmens et al. (1995)

Lemmens et al. (1995)

\subsubsection{SE monsoon (July $10-$ November 15,2002 )}

Samples collected during the SE monsoon are relatively enriched in Casuarina pollen, that are on average $5 \%$ higher than in the previous period. Casuarina is a characteristic tree of the Australian vegetation (Beadle, 1981; Johns, 1982; van der Kaars, 1991). However, it has to be considered that one species, Casuarina junghuhniana, is native on Java and occurs in littoral areas and in highlands, e.g. mountain forests to the east of Mt. Lawu on the border between Central and East Java, as well as on Krakatoa (Whitmore, 1990). These sites might form additional source areas of the trapped Casuarina pollen. During the NW monsoon, when pollen transport from the South is almost absent, the portion of Casuarina pollen is about 3\% on average. Therefore, we conclude that some of the trapped pollen of Casuarina (up to about 7\%) originate from the South, in particular from northern Australia, and may be transported to the area by marine currents (e.g. the South Equatorial Current, Southern Java Current and partly by the Leeuwin Current, Fig. 3.1).

Eucalyptus has been planted on Java since 1800, especially in the mountainous areas of Central Java such as the Dieng plateau, Mount Sumbing and Mount Sundoro (Pramono and Pudjiharta, 1996), at Pasuruan (East Java) and at a number of experimental stations (Food Agricultural Organisation, FAO Report, 1979; Webb et al., 1984). Another source area for Eucalyptus pollen may be northern Australia, where this tree is very common (Specht, 1970; Pryor, 1976; Soerianegara and Lemmens, 1993). However, during the NW monsoon, when input from the south is likely to be absent, 
Eucalyptus accounted for up to 4\% (sample D3) of the total pollen. Values of Eucalyptus pollen during the SE monsoon period are of the same rate (up to 3-4\%). This suggests that only small amounts of Eucalyptus pollen are transported into the area during the SE monsoon (some 2\%). Most Eucalyptus pollen during that period are considered to reflect regional production.

In Australia, the maximum flowering period for both Eucalyptus and Casuarina occurs from April to June (Table 3.2). The calculated delay between flowering time in Australia and the accumulation of Casuarina pollen in the trap suggests a transportation time of roughly 1 to 2 months. In the case of Eucalyptus, the assumption is difficult to make as in Indonesia it can have flowers throughout the year (Soerianegara and Lemmens, 1993). The maximum pollen percentages of Podocarpus, which is a characteristic tree in the mountain forest of West Java, correspond with the flowering period (Table 3.2).

3.5.3. Pollen accumulation rate in comparison to the accumulation rates of other proxies in the sediment trap studies off SW Java

The extrapolated PAR of 1670 grains $/ \mathrm{cm}^{2} / \mathrm{yr}$ for the recorded period is rather high compared to the data obtained from the eastern Indonesian marine sediment cores (van der Kaars, 1991), in which pollen and spore fluxes varied during the Holocene from 1.6 grains $/ \mathrm{cm}^{2} / \mathrm{yr}$ and $2.9 \mathrm{spores} / \mathrm{cm}^{2} / \mathrm{yr}$ in the Lombok Ridge core to 55 grains $/ \mathrm{cm}^{2} / \mathrm{yr}$ and 183 spores/cm2/yr in the Weber Deep core. In the Malluca Sea before the Late Glacial Maximum, pollen influx rates show comparable values, of less than 100 grains $/ \mathrm{cm}^{2} / \mathrm{yr}$ (Barmawidjaja et al., 1993). Approximately the same low pollen influx values are reported for the Sunda Shelf (Wang et al., 2007).

Other proxies from the same trap, such as diatoms, showed the highest fluxes during the SE monsoon in September 2001, during the NW monsoon in February/March 2003 and during early SE monsoon in 2003 (Romero et al., 2009). In the case of foraminifera (the sediment trap JAM1-JAM3 series including our trap JAM2), both total and species specific fluxes, as well as measured opal and organic carbon, were highest during the late SE monsoon (Rixen et al., 2006a,2006b; Mohtadi et al., 2009).

In our study, the reason for the increasing PAR during the intermonsoon period compared to the monsoon periods is yet unclear, but may be a late consequence of the increased rainfall and the high discharge of the associated rivers during the late NW monsoon season (February-April). It might also be related to the rainout of the wind transported component. The latter scenario is however more unlikely as it would induce an increase in "northern" pollen concentrations in the association which we do not observe. Another reason for the increased PAR during the intermonsoon period might be related to the generally high local pollen input from Java and the absence of monsoon influence, transporting low concentrations of pollen from the long distance to the trap and blowing/washing away the high concentrations of regionally produced pollen.

\subsection{Conclusions}

Marine sediment trap samples, collected from December 2001-November 2002 (at 16 days intervals), at a water-depth of about $2200 \mathrm{~m}, 60 \mathrm{~km}$ off SW Java in the Indian Ocean in Indonesia, have been investigated for pollen abundance and composition. We draw the following conclusions: 
(1) Accumulated pollen and spores reflect the present-day vegetation of SW Java well. Both fluvial and aeolian fluxes, as well as transport by ocean currents, play a role in transportation of pollen and spores to the trap site.

(2) The abundance of pioneer taxa pollen, such as Macaranga/Mallotus, Acalypha, Ficus and Trema, as well as high values of Poaceae, indicates the occurrence of secondary forest and isrelated to the intensification of land use.

(3) Mangroves are represented by only a few pollen grains. We assume that this is a result of the widespread destruction of the mangrove belt on Java during the last decades.

(4) During the NW monsoon (mid-December-beginning of March) the pollen assemblages are strongly influenced by transport of pollen from continental Asia and Sumatra, whereas pollen from northern Australia arrives at the trap site during the SE monsoon (end of July-November).

(5) Pollen assemblages collected during the intermonsoon period (beginning of March-end of July) originate mainly from SW Java.

(6) Long distance transport plays a marked role for pollen accumulation during the monsoon seasons (10-24\% during NW monsoon and 3-10\% during the SE monsoon).

(7) The pollen record suggests that maxima of Elaeocarpus, Myrica, Dacrycarpus, Casuarina and Podocarpus in the sediment trap may be related to their flowering periods. In the case of Elaeocarpus, a one month difference between flowering time and pollen accumulation in the sediment trap has been recorded. For Myrica, Dacrycarpus and Casuarina the offset time is about 12 months.

(8) Pollen and spore accumulation rates increase during the intermonsoon period compared to the monsoon periods. The reason might be related to a stronger input of pollen from SW Java as a late consequence of the increased rainfall and associated high river discharges at the end of the NW monsoon season (February-April) and $/ o r$ to the absence of the monsoon influence blowing/washing the local pollen away.

\subsection{Acknowledgments}

Field material for the present research was collected during the cruise SO-184, PABESIA, 2005 funded by the Bundesministerium für Bildung und Forschung (BMBF grant no. 03G0184A) within the framework of the project "Biogeochemical fluxes in Indonesian Seas" (BMBF grant no. 03F0463A). The authors express their gratitude to the crew of the research vessel SONNE, and to M. Segl and B. Meyer-Schack for technical support. This study has been carried out within the German-Indonesian bilateral program "Science for the Protection of Indonesian Coastal Marine Ecosystems (SPICE III CAFINDO, BMBF grant no. 03F0645C)". We thank Ursula Grothmann and Uta Nüsse-Hahne for their support in the laboratory. Jörg Christiansen gets our regards for his computer assistance. Dr. Karin Zonneveld is thanked for her consultations as well as for reading the manuscript at its final stage. Regional Editor of the Journal Marine Micropaleontology Prof. Frans Jorissen and two anonymous reviewers are greatly acknowledged for critically reviewing the manuscript and for their detailed and useful comments and suggestions. Cate Hancock is thanked for her assistance with the English. 
Appendix A. List of identified pollen and spore types from marinesediment trap JAM2

\begin{tabular}{|c|c|}
\hline Mangrove & $\begin{array}{l}\text { Avicennia } \\
\text { Nypa } \\
\text { Rhizophora }\end{array}$ \\
\hline Lowland trees & $\begin{array}{l}\text { Acalypha } \\
\text { Acanthaceae } \\
\text { Alchornea } \\
\text { Anacardiaceae } \\
\text { Arecaceae } \\
\text { Arenga } \\
\text { Bignoniaceae type } \\
\text { Caryota type } \\
\text { Celtis } \\
\text { Clethra } \\
\text { Cunoniaceae } \\
\text { Elaeocarpus } \\
\text { Euphorbiaceae } \\
\text { Ficus type } \\
\text { Lamiaceae } \\
\text { Loranthaceae } \\
\text { Macaranga / Mallotus } \\
\text { Mimosaceae } \\
\text { Moraceae / Urticaceae } \\
\text { Myrtaceae } \\
\text { Oleaceae } \\
\text { Oleaceae 4-porate } \\
\text { Oncosperma } \\
\text { Pometia } \\
\text { Rosaceae type } \\
\text { Rubiaceae } \\
\text { Rutaceae type } \\
\text { Sapindaceae / Meliaceae } \\
\text { Sapotaceae } \\
\text { Trema type }\end{array}$ \\
\hline Montane trees & $\begin{array}{l}\text { Allophylus } \\
\text { Combretaceae / Melastomataceae } \\
\text { Dacrycarpus type } \\
\text { Engelhardia } \\
\text { Ericaceae } \\
\text { Ilex } \\
\text { Lithocarpus / Castanopsis } \\
\text { Myrica } \\
\text { Myrsinaceae } \\
\text { Podocarpus type }\end{array}$ \\
\hline Herbs & $\begin{array}{l}\text { Amaranthaceae / Chenopodiaceae } \\
\text { Asteraceae } \\
\text { Caryophyllaceae } \\
\text { Cichorium }\end{array}$ \\
\hline
\end{tabular}

64 


\begin{tabular}{|c|c|}
\hline & Cucurbitaceae type \\
\hline & Cyperaceae \\
\hline & Iridaceae / Liliaceae \\
\hline & Malvaceae \\
\hline & Oryza type \\
\hline & Plantago \\
\hline & Poaceae \\
\hline & Zea mais type \\
\hline Long distance component & Alnus \\
\hline (northern subgroup) & Picea type \\
\hline & Pinus \\
\hline & Quercus \\
\hline & Ranunculaceae type \\
\hline & Thymeliaceae type \\
\hline & Ulmus \\
\hline Long distance component & Casuarina \\
\hline (southern subgroup) & Eucalyptus \\
\hline Pteridophyta & Cyathea \\
\hline & Davallia type \\
\hline & Huperzia type \\
\hline & Lycopodium \\
\hline & Ophioglossum type \\
\hline & Osmunda type \\
\hline & Selaginella \\
\hline & Polypodiaceae monolete baculate type \\
\hline & Polypodiaceae monolete echinate type \\
\hline & Polypodiaceae monolete psilate type \\
\hline & Polypodiaceae monolete reticulate type \\
\hline & Polypodiaceae monolete verrucate type \\
\hline & Polypodiaceae trilete echinate type \\
\hline & Polypodiaceae trilete reticulate type \\
\hline & Polypodiaceae trilete psilate type \\
\hline & Polypodiaceae trilete scabrate type \\
\hline & Polypodiaceae trilete verrucate type \\
\hline
\end{tabular}

Appendix B. Supplementary data

Supplementary data to this article can be found online at http://dx. doi.org/10.1016/j.marmicro.2014.06.006. These data include Google maps of the most important areas described in this article.

\subsection{References}

Australian Digital Pollen and Spore Atlas (ASPA). http://apsa.anu.edu.au (last access September 2013).

Backer, C.A., van den Brink, B., 1965. Flora of Java. Volumes I-III. N. V. P. Noordhoff, Groningen. 
Barmawidjaja, B. M., Rohling, E. J., van der Kaars, W.A., Vergnaud-Grazzini, C., Zachariasse, W. J., 1993. Glacial conditions in the northern Molucca Sea region Indonesia. Palaeogeography Palaeoclimatology Palaeoecology 101(1-2), 147-167.

Beadle, N.C.W., 1981. The Vegetation of Australia. Cambridge University Press, Cambridge.

Beuning, K.R.M., 1996. Modern pollen rain, vegetation and climate in lowland East Java, Indonesia. Modern Quaternary Research in Southeast Asia 14. A. A. Balkema Publishers, Rotterdam.

Black, D.E., 2002. The rains may be 'a-comin'. Science 297, 528-529.

Boomsma, C.D., 1972. Native Trees of South Australia. Government Press, Adelaide.

Burbidge, N.T., 1960. The phytogeography of the Australian region. Australian Journal of Botany 8 , 75-211.

Buschman, F.A., Hoitink, A.J.F., de Jong, S.M., Hoekstra, P., 2011. Suspended sediment fluxes in an Indonesian River draining a rainforested basin subject to land cover change. Hydrology and Earth System Sciences Discussions 8, 7137 - 7175

Collins, N. M., Sayer, J. A., Whitmore, T. C., 1991. The Conservation Atlas of Tropical Forests: Asia and Pacific. Macmillan Press, London.

Continental Southeast Asia - Forest cover map, 1998-2000. http://bioval.jrc.ec.europa.eu (last access February, 2014).

Choong, E.T., Wirakusumah, R.S., Achmadi, S.S., 1990. Mangrove forest resources in Indonesia. Forest Ecology and Management 33/34, 45-57.

Dai, L., Weng, C., 2011. A survey on pollen dispersal in the western Pacific Ocean and its paleoclimatological significance as a proxy for variation of the Asian winter monsoon. Science China. Earth Sciences 54 (2), 249-258.

Faegri, K., Iversen, J., 1975. Textbook of Pollen Analysis (4th Ed.). J. Wiley \& Sons Ltd., Chichester.

Food and Agricultural Organisation (FAO) Report, 1979. Eucalyptus for planting. FAO Forestry Series 11 , Rome, Italy.

Food and Agricultural Organisation (FAO) Report, 2007. The world's mangrove 1980-2005. FAO Forestry Paper 153, Rome, Italy.

Food and Agricultural Organisation (FAO) Report, 2010. Global Forest Resources Assessment. FAO Forestry Paper 163, Rome, Italy.

Flenley, J.R., 1979. The Equatorial Rain Forest: a Geological History. Butterworths, London.

Fujiki, T., Zhou, Z., Yasuda, Ya., 2005. The Pollen Flora of Yunnan, China. Lustre Press/Roli Books, New Delhi.

Fang, G., Wang, Y., Wei, Z., Fang, Y., Qiao, F., Hu, X., 2009. Interocean circulation and heat and freshwater budgets of the South China Sea based on a numerical model. Dynamics of Atmospheres and Oceans 47, 55-72.

Gordon, A.L., 2005. Oceanography of the Indonesian seas and their throughflow. Oceanography 18 (4), 14-27.

Grimm, E.C., 1987. CONISS: A FORTRAN 77 program for stratigraphically constrained cluster analysis by method of incrimination sum of squares. Computers and Geosciences 13 (1), 13-35.

Heusser, L.E., 1988. Pollen distribution in marine sediments on the continental margin off northern California. Mar. Geol. 80, 131-147.

Heusser, L.E., Balsam, W.L., 1977. Pollen distribution in the northeast Pacific Ocean. Quat. Res. 7, 4562.

Honjo, S., Doherty, K.W., 1988. Large aperture time-series sediment traps: Design, objectives, construction and application. Deep-Sea Research 35 (1), 133-149.

Hooghiemstra, H., Agwu, C.O.C., Beug, H.-J., 1986. Pollen and spore distribution in recent marine sediments: a record of NW-African seasonal wind patterns and vegetation belts. Meteorologische Forschungsergebnisse 40, 87-135.

Hutomo, M., Moosa, M. K., 2005. Indonesian Coastal and marine biodiversity: Present status. Indian Journal of Marine Sciences 14 (1), 88-97.

Insular Southeast Asia - Forest Cover Map, 1998-2000. http://bioval.jrc.ec.europa.eu (last access February, 2014). 
Johns, R.J., 1982. Plant zonation. In: Gressitt, J.L. (Ed.), Biogeography and Ecology of New Guinea. Junk, The Hague, pp. 309-330.

Kershaw, A.P., Van der Kaars, S., Flenley, J.F., 2011. The Quaternary history of far eastern rainforests (Second Edition). In: Bush, M.B., Flenley, J.F., Gosling, W.D. (Eds.) Tropical Rainforest Responses to Climate Change. Springer-Verlag, Berlin Heidelberg, pp. 85 - 123.

Lemmens, R.H.M.J., Soerianegara, I., Wong, W.C. (Eds.), 1995. Plant Resources of Southeast Asia. Timber Trees: Minor Commercial Timbers. Backhuys Publishers, Leiden.

Mao, L., Batten, D., Fujiki, T., Li, Z., Dai, L., Weng, Ch., 2012. Key to mangrove pollen and spores of southern China: an aid to palynological interpretation of Quaternary deposits in the Southern China Sea. Review of Palaeobotany and Palynology 176-177, 41-67.

Milliman, J. D., Farnsworth, K. L., Albertin, C. S., 1999. Flux and fate of fluvial sediments leaving large islands in the East Indies. Journal of Sea Research 41, 97 - 107.

Mohtadi, M., Steinke, S., Groeneveld, J., Fink, H.G., Rixen, T., Hebbeln, D., Donner, B., Herunadi, P., 2009. Low-latitude control on seasonal and interannual changes in planktonic foraminiferal flux and shell geochemistry off south Java: A sediment trap study. Paleoceanography 24, 1-20.

Monk, K.A., de Fretes, Y., Reksodiharjo-Lolley, G., 1997. The Ecology of Nusa Tenggara and Malluku. Periplus Press, Singapore.

Maloney, B.K., 1985. Ulmus pollen at Sibisa Swamp, North Sumatra. Blumea 31, 123-127.

Moore, G. F., Curray, J. R., Moore, D. G., Karig, D. E., 1980. Variations in geologic structure along the Sunda Fore Arc, northeastern Indian Ocean. In: Hayes, D. E. (Ed.), The Tectonic and Geologic Evolution of Southeast Asian Seas and Islands. American Geophysical Union Monograph 23, pp. 145-160.

Moore, P.D., Webb, J.A., 1978. An Illustrated Guide to Pollen Analysis. Hodder and Stoughton, London.

Morton, J.-F., 1980. The australian pine or beefwood (Casuarina equisetifolia L.), an invasive "weed" in Florida. Proceedings of Florida State Horticultural Society 93, 87-95.

Muller, J., 1959. Palynology of Recent Orinoco delta and shelf sediments: Reports of the Orinoco Shelf Expedition, Vol. 5. Micropaleontology 5, 1-32.

Muller, J., 1972. Palynological evidence for change in geomorphology, climate and vegetation in the Mio-Pliocene of Malesia. In: Ashton, P., Ashton, M., (Eds.). The Quaternary Era in Malesia. Department of Geography, University of Hull, pp. 6-16.

Polhaupessy, A.A., 1980. The palynological study of ancient Lake Bandung. Bulletin of the Geological Research and Development Centre Bendung 3, 19-23.

Polhaupessy, A.A., 1981. Quaternary vegetational history of Batajaya. Bulletin of the Geological Research and Development Centre Bendung 5, 30-36.

Pramono, I.B., Pudjiharta, A., 1996. Research experiences on Eucalyptus in Indonesia. In: Reports Submitted to the Regional Expert Consultation on Eucalyptus. RAP Publication (FAO), Bangkok, pp. 75-83.

Pryor, L.D., 1976. The Biology of Eucalyptus. Edward Arnold, London.

Pudjoarinto, A., Cushing, E.J., 2001. Pollen-stratigraphic evidence of human activity at Dieng, Central Java. Palaeogeography, Palaeoclimatology, Palaeoecology 3-4, 329-340.

Richards, P.W., 1952. The Tropical Rainforest. An Ecological Study. Cambridge University Press, Cambridge.

Rixen, T., Venugopalan, I., Herunadi, B., Wetzel, P., Maier-Reimer, E., Gaye-Haake, B., 2006a. ENSOdriven carbon see saw in the Indo-Pacific. Geophysical Research Letters 33, 1- 4.

Rixen, T., Ittekkot, V., Herundi, B., Wetzel, P., Maier-Reimer, E., Gaye-Haake, B., 2006b. ENSO-driven carbon see saw in the Indo-Pacific. Journal of Geophysical Research Letters 33 (L07606), doi:10.1029/2005GL024965.

Romero, O.E., Rixen, T., Herunadi, B., 2009. Effects of hydrographic and climatic forcing on diatom production and export in the tropical southeastern Indian Ocean. Marine Ecology. Progress Series 384, 69-82. 
Ropelewski, C. F., Halpert, M.S., 1987. Global and regional scale precipitation patterns associated with El Niňo/Southern Oscillation. Monthly Weather Reviews 115, 1606-1626.

Schott, F., McCreary, J. P., 2001. The monsoon circulation of the Indian Ocean. Progress in Oceanography 51, 1-123.

Semah, A-M., 1984. Remarks on the pollen analysis of the Sambungmacan section (Central Java). Modern Quaternary Research in Southern Asia 8, 29-34.

Sijatauw, W.E., 1973. Rainfall Atlas of Indonesia. Java and Madura 1931-60. Meteorology and Geophysics Institute, Jakarta.

Soerianegara, I., Lemmens, R.H.M.J., (Eds.), 1993. Plant Resources of South-East Asia. Timber Trees: Major Commercial Timbers. Pudoc Scientific Publischers, Wageningen.

Sosef, M.S.M., Hong, L.T., Prawirohatmodjo, S. (Eds.), 1998. Plant Resources of South-East Asia. Timber Trees: Lesser-Known Timbers. Backhuys Publishers, Leiden.

Specht, R.L., 1970. Vegetation. In: Leeper, G.W. (Ed.), The Australian Environment. CSIRO and Melbourne University Press, Melbourne, pp. 44-67.

Stibig, H-J., Achard, F., Fritz, S., 2004. A new forest cover map of continental Southeast Asia derived from satellite imagery of coarse spatial resolution. Applied Vegetation Science 7, 153-162.

Stibig, H-J., Beuchle, R., Achard, F., 2003. Mapping of the tropical forest cover of insular Southeast Asia from SPOT4-Vegetation images. International Journal of Remote Sensing 24 (18), 36513662.

Stibig, H-J., Malingreau, J.P., 2003. Forest cover of insular southeast Asia mapped from recent satellite images of coarse spatial resolution. Ambio 32 (7), 469-475.

Stockmarr, J., 1971. Tablets with spores used in absolute pollen analysis. Pollen and Spores 13, 61521.

Stuijts, I., Newsome, J.C., Flenley, J.R., 1988. Evidence for Late Quaternary vegetational change in the Sumatran and Javan highlands. Review of Palaeobotany and Palynology 55, 207-216.

Stuijts, I., 1984. Palynological study of Situ Bayongbong, West Java. Modern Quaternary Research in South-East Asia 8, 17-27.

Stuijts, I., 1993. Late Pleistocene and Holocene vegetation of West Java, Indonesia. Modern Quaternary Research in South-East Asia 12, A. A. Balkema Publishers, Rotterdam.

Sukardjo, S., 1990. Conservation of mangroves formations in Java. In: The Plant Diversity in Malaysia. Baas, P., Klakman, K., Geesink, R. (Eds.). Dordrecht, Kluwer, pp. 329-340.

Sun, X., Li, X., Beug, H-J., 1999. Pollen distribution in hemipelagic surface sediments of the South China Sea and its relation to modern vegetation distribution. Marine Geology 156, 211-226.

Sun, X.-J., Li, X., Luo, Yu.-L., 2002. Vegetation and climate on the Sunda Shelf of the South China Sea during the Last Glaciation - Pollen results from station 17962. Acta Botanica Sinica 44 (6), 746752.

Tomczak, M., Godfrey, J.S., 1994. Regional Oceanography: An Introduction. Pergamon, Oxford.

Van der Kaars, S., 1991. Palynology of eastern Indonesian piston cores: a Late Quaternary vegetational and climatic record for Australasia. Palaeogeography, Palaeoclimatology, Palaeoecology 85, 239-302.

Van der Kaars, S., 1998. Marine and terrestrial pollen records of the last glacial cycle from the Indonesian region: Bandung Basin and Banda Sea. Palaeoclimates 3, 209 - 219.

Van der Kaars, S., 2001. Pollen distribution in marine sediments from the south-eastern Indonesian waters. Palaeogeography, Palaeoclimatology, Palaeoecology 171, 341-361.

Van der Kaars, S., Dam, M.A.C., 1995. A 135,000 year record of vegetational and climatic change from the Bandung area, West Java, Indonesia. Palaeogeography, Palaeoclimatology, Palaeoecology $117(1-2), 55-72$.

Van der Kaars, S., Dam, M.A.C., 1997. Vegetation and climate change in West Java, Indonesia during the last 135,000 years. Quaternary International 37, 67-71.

Van der Kaars, S., De Deckker, P., 2002. A late Quaternary pollen record from deep-sea core FR10/95GC17 offshore Cape Range Peninsula, northwestern Western Australia. Review of Palaeobotany and Palynology 120, 17-39. 
Van der Kaars, S., Wang, X., Kershaw, A.P., Guichard, F., Setiabudi, D.A., 2000. A Late Quaternary palaeoecological record from the Banda Sea, Indonesia: Patterns of vegetation, climate and biomass burning in Indonesia and northern Australia. Palaeogeography, Palaeoclimatology, Palaeoecology 155, 135-153.

Van Steenis, C.G.G.J., 1984. Floristic altitudinal zones in Malaysia. Botanical Journal of the Linnean Society 89, 289-292.

Van Waveren, I.M., 1989. Palynofacies analysis of surface sediments from the northeastern Banda Sea (Indonesia). Netherlands Journal of Sea Research 24 (4), 501-509.

Wang, F., Chien, N., Yulong, Z., Yang, H., 1995. Pollen Flora of China (2nd Ed.). Institute of Botany. Academia Sinica, Beijing.

Wang, P., Prell, W., Blum, P., 2000. Proceedings of the ocean drilling program. Texas A\&M University, college station TX 778445-9547. Initial Reports 184, 1- 48.

Wang, P., Clemens, S., Beaufort, L., Braconnot, P., Ganssen, G., Jian, Z., Kershaw, P., Sarnthein, M., 2005. Evolution and variability of the Asian monsoon system: State of the art and outstanding issues, Quaternary Science Review 24 (5-6), 595-629.

Wang, X., Van der Kaars, S., Kershaw, A.P., Bird, M., Jansen, F., 1999. A record of vegetation and climate through the last three glacial cycles from Lombok Ridge core G6-4, eastern Indian Ocean, Indonesia. Palaeogeography, Palaeoclimatology, Palaeoecology 147, 241-256.

Wang, X. M., Sun, X. J., Wang, P. X., Stattegger, K., 2007. A high-resolution history of vegetation and climate history on Sunda Shelf since the last glaciation. Science in China Series D-Earth Sciences 50 (1), 75-80.

Webb, D.B., Wood, P.J., Smith, J.P., Henman, G.S., 1984. A guide to species selection for tropical and sub-tropical plantations. Tropical Forestry Papers, 15. Unit of Tropical Silviculture, Commonwealth Forestry Institute, University of Oxford.

Whitmore, T.C., 1984. Tropical Rain Forest of the Far East. Clarendon Press, Oxford.

Whitmore, T.C., 1990. An Introduction to Tropical Rain Forest. Clarendon Press, Oxford.

Whitten, T., Soeriaatmadja, R. E., Afiff, S.A., 1996. The Ecology of Java and Bali. Periplus Editions, Singapore.

Wijffels, S., Hautala, S., Meyers, G., Morawitz, W., 1996. The WOCE Indonesian Throughflow repeat hydrography sections: 110 and IR6. International WOCE Newsletter 24, 25-28.

Wijffels, S., Sprintall, J., Fieux, M., Bray, N., 2002. The JADE and WOCE I10 / IR6 Throughflow sections in the southeast Indian Ocean. Part 1: Watermass distribution and variability. Deep Sea Research Part II: Topical Studies in Oceanography 49 (7-8), 1341-1362.

Wyrtki, K., 1957. Die Zirkulation an der Oberfläche der Südostasiatischen Gewässer. Deutsch Hydrographische Zeitschrift 10 (1), 1-13.

Yulianto, E., Hiroyuki, T., Sri, S., Noriyuki, T., 2005. A Holocene pollen and charcoal record from a tropical lowland swamp in Rawa Danau, West Java, Indonesia. Tropics 14, 271-281.

Zheng, Q., Fang, G., Song, Y.T., 2006. Introduction to special section: Dynamic processes and circulation in Yellow Sea, East China Sea and South China Sea. Journal of Geophysical Research 111, 1-5. 


\title{
CHAPTER 4
}

Marine environment, vegetation, and land use changes related to the human impact during the late Holocene in South Kalimantan and East Java based on pollen and dinoflagellate cysts

\author{
Anastasia Poliakova ${ }^{1 *}$, Karin A. F. Zonneveld ${ }^{2,3}$, Cornelia Kwiatkowski ${ }^{3}$, \\ Mustaba Ari Suryoko ${ }^{4}$, Hermann Behling ${ }^{1}$
}

(1) Georg-August-University of Göttingen, Albrecht-von-Haller-Institute for Plant Sciences, Department of Palynology and Climate Dynamics, Untere Karspüle 2, 37073 Göttingen, Germany.

(2) University of Bremen, D-28334 Bremen, Germany.

(3) Center for Marine Environmental Sciences (MARUM), University of Bremen, Leobener Straße, D-28359 Bremen, Germany.

(4) Marine Geological Institute, ESDM, Bandung, Indonesia.

Submitted to Review of Palaeobotany and Palynology

Key words: late Holocene, reconstruction of palaeoenvironment, past vegetation, anthropogenic influence, marine sediment cores, Java Sea 


\section{Abstract}

The pollen, spore and organic walled dinoflagellete cyst associations of two marine sediment cores from the Java Sea off the mouths of Jelai River (S Kalimantan) and Solo River (E Java) reflect environment and vegetation changes for the last ca 3500 years. A decline in primary forest taxa (e.g. Agathis, Allophylus, Dacrycarpus, Dacrydium, Dipterocarpaceae, Phyllocladus and Podocarpus) suggest that the major change in vegetation is caused by forest canopy disturbance possibly as a consequence of human activity. The successive increase in pollen of pioneer tress/shrubs and herb taxa (e.g. Acalypha, Ficus, Macaranga/Mallotus, Trema, Pandanus) indicate the development of secondary vegetation. In Java these changes started much earlier (ca at $2950 \mathrm{cal}$ yr BP) than in Kalimantan (ca at $910 \mathrm{cal}$ yr BP) and seem to be more severe. Changes in the marine realm, reflected by the dinoflagellate cyst association, correspond to the changes in vegetation on land. They reflect a gradual change from relatively well ventilated to more hypoxic bottom/pore water conditions in a more eutrophic environment. Near the coast of Java, the shift of the water trophic status took place between ca 820 and 500 cal yr BP, while near the coast of Kalimantan it occurred as late as at the beginning of the $20^{\text {th }}$ century. We observe an increasing amount of the cysts of Polykrikos schwartzii, P. kofoidii, Lingulodinium machaerophorum, Nematosphaeropsis labyrinthus and Selenopemphix nephroides at times of secondary vegetation development on land, suggesting that human induced terrestrial changes possibly affected the marine environment as well, most likely through increased eutrophication and pollution.

\subsection{Introduction}

The concern about the effects of human activities on environment and climate has increased considerably during the last decades. It is essential to know to what extent environments are affected not only by human activity, but also by natural e.g. climatic and ecosystem's variability. Such information can be achieved by studying natural archives that cover time intervals previous to and during major anthropogenic influences. Marine sediment archives from high deposition areas have the potential to provide this information as they contain continuous sequences with high temporal resolution. Pollen and spores are valuable proxies for reconstructing vegetation change on the continent because of their good preservation, abundant presence in most terrestrial and marine sediments (Dupont, 1999; Anshari et al., 2001; Donders et al., 2005; Willard et al., 2007). Their content in marine sediments can reflect both natural and anthropogenic induced vegetation changes as well variations in runoff rates (Donders et al., 2008). The sedimentary charcoal content can be used to provide information about the fire history of an area or region (Higuera et al., 2010). The fireecology can be studied when this is compared to palynological based vegetation reconstructions (e.g. Colombaroli et al., 2007, Conedera et al., 2009, Daniau et al., 2010, Kaltenrieder et al., 2010).

Associations of organic walled dinoflagellate cysts (dinocysts) reflect changes in upper water conditions in detail. Therefore they are suitable to reconstruct marine environmental conditions such as sea surface temperature (SST), sea surface salinity (SSS) trophic state and the redox state of bottom/sediment-pore water environments (e.g. De Vernal et al., 1997; Marret et al., 2001; Dale et al., 2002; Sangiorgi et al., 2002; Zonneveld, 2003; Pospelova et al., 2006; Van der Meer et al., 2008; Chen et al., 2011). Furthermore, they are very useful to distinguish anthropogenic disturbances in marine ecosystems (e.g. Pospelova et al., 2002, Shin et al., 2010, Zonneveld et al., 2012).

Tropical regions are very sensitive to climate fluctuations and to spatial gradients in SST. Minor changes in the sea level or in SST may largely modify tropical climate (Chiang and Koutavas, 2004). This has a direct effect on the vegetation on the continent. Apart from natural factors influencing vegetation composition, the forest ecosystems in Indonesia have experienced a long history of the anthropogenic impact which is increasing annually (FAO, 2010; 2012). 
Nowadays a large amount of information is available from late Holocene terrestrial deposits on Java (Semah, 1982, 1984, 2004; Stuijts, 1984, 1993; Stuijts et al., 1988; Grindrod et al., 2002) and Kalimantan (e.g. Anderson and Muller, 1975; Morley, 1981; Caratini and Tissot, 1988; Anshari et al., 2001; Gusti et al., 2001; Weiss, 2002; Anshari et al., 2004; Yulianto et al., 2005) as well as in the southern Indonesia (e.g. Dubois et al., 2014). A number of publications on the late Holocene marine environment are available from the Banda Sea (Van der Kaars, 1991, 1997; Van der Kaars et al., 2000; Ahmad et al., 1995; Van der Kaars, 2000; Van Waveren, 1989; Spooner et al., 2005), Celebes Sea (van der Kaars, 1991), Sulu Sea (Beaufort et al., 2003), Molucca Sea (Barmawidjaja et al., 1993), Mahakam Delta, Kalimantan (Caratini and Tissot, 1988), the Makassar Strait (Yulianto, 2004; Visser et al., 2004), for the western (e.g. Kuhnert et al., 2014; Niedermeyer et al., 2014) and eastern Indian Ocean (Wang, et al., 1999, Baumgart et al., 2010; Mohtadi et al., 2010, 2011; Hessler at al., 2013; Chen et al., 2014) and off Sumatra (van der Kaars et al., 2010, 2012). Information of the Java Sea is almost missing (Emery, 1972; Boely et al., 1991; Suryantini et al., 2011) and palynological studies from the Java Sea are absent. Little attention is paid to the relationship between sea and land, although they are crucial for such areas with monsoon climate as in Indonesia. With this paper, we would like to contribute in filling this gap. We use marine palynology to obtain better understanding of the relations between climatic vs. the human activity related changes on land and in the marine realm during the last 3500 years. To obtain insight into the relationship between natural and anthropogenic processes affecting both the marine and terrestrial environment, we establish detailed reconstructions of environmental changes that contemporaneously took place on the continent as well as in the adjacent marine environment. This is achieved by comparing information data inferred from pollen/spore and dinocyst associations in marine sediments off S Kalimantan and E Java.

\subsection{Regional settings}

The Java Sea is a large $\left(310,000 \mathrm{~km}^{2}\right)$ shallow sea (in general between $40-100 \mathrm{~m}$ water depth) on the Sunda Shelf which lies between the islands of Kalimantan (Borneo) to the north, Java to the south; Sumatra to the west and Sulawesi to the east (Fig.4.1). In the west it is in open to the Indian Ocean, the Andaman Sea and S China Sea by the Sunda Strait, the Malacca Strait and the Karimata Strait, respectively. In the east it has an open connection to the Flores Sea and to the Celebes Sea through the Makassar Strait (Durand and Petit, 1995; Genia et al., 2007).

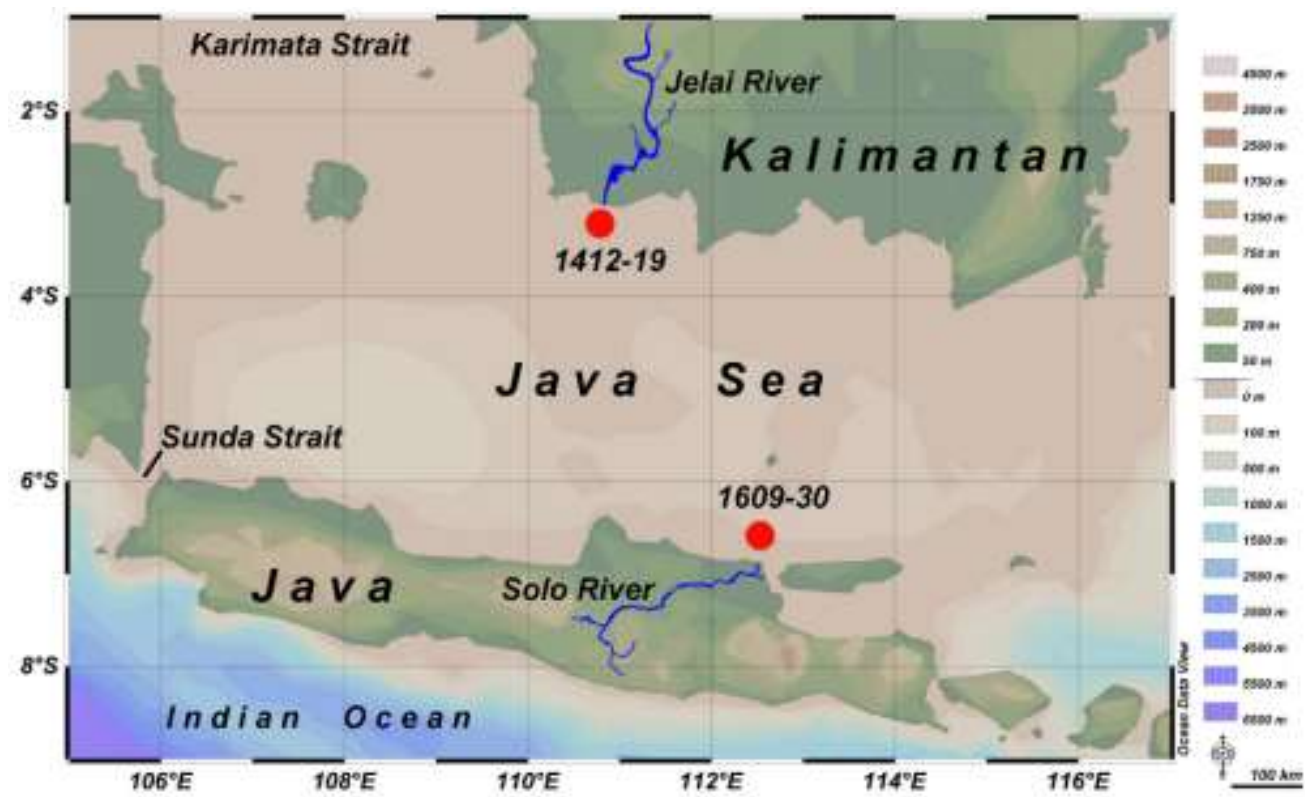

Fig.4.1. Schematic map of the study area. Position of cores 1412 19 and $1609-30$ is shown with red circles. The map has been created using the Ocean Data View software (Schlitzer, 2014). 


\subsubsection{Modern climate}

The region has a typical monsoon climate marked by a reversal of the wind regimes (Fig. 4.2) (Durand and Petit, 1995). During the Northwest (NW) monsoon (December to February; Fig. 4.2, left picture) strong western winds bring frequently heavy rainfall (precipitation of up to $300 \mathrm{~mm} / \mathrm{month}$; Writky, 1961). During the Southeast (SE) monsoon (June to August; Fig. 4.2, right picture) the winds are reversed and blow from east to west, resulting in drier weather conditions (precipitation can be as little as $50 \mathrm{~mm} / \mathrm{month}$; Durand and Petit, 1995). The average annual rate of precipitation is about $1880 \mathrm{~mm}$. During the transitional months precipitation rates increase (decrease) gradually. Usually during the NW monsoon the highest temperatures are found in the eastern part of the sea (e.g. Durand and Petit, 1995) and the lowest ones in the west part of the region along the coasts of Sumatra. During the SE monsoon this gradient is reversed and highest temperatures are then found in the west (Potier et al., 1989; Genia et al., 2007). The rate of precipitation is strongly connected to the climate anomaly known as ENSO (EI Niňo Southern Oscillation), with its two extreme phases, El Niňo and La Niňa, reflecting decreases and increases in precipitation rates over Indonesia (Ropelewski and Halpert, 1987; Aldrian and Susanto, 2006).

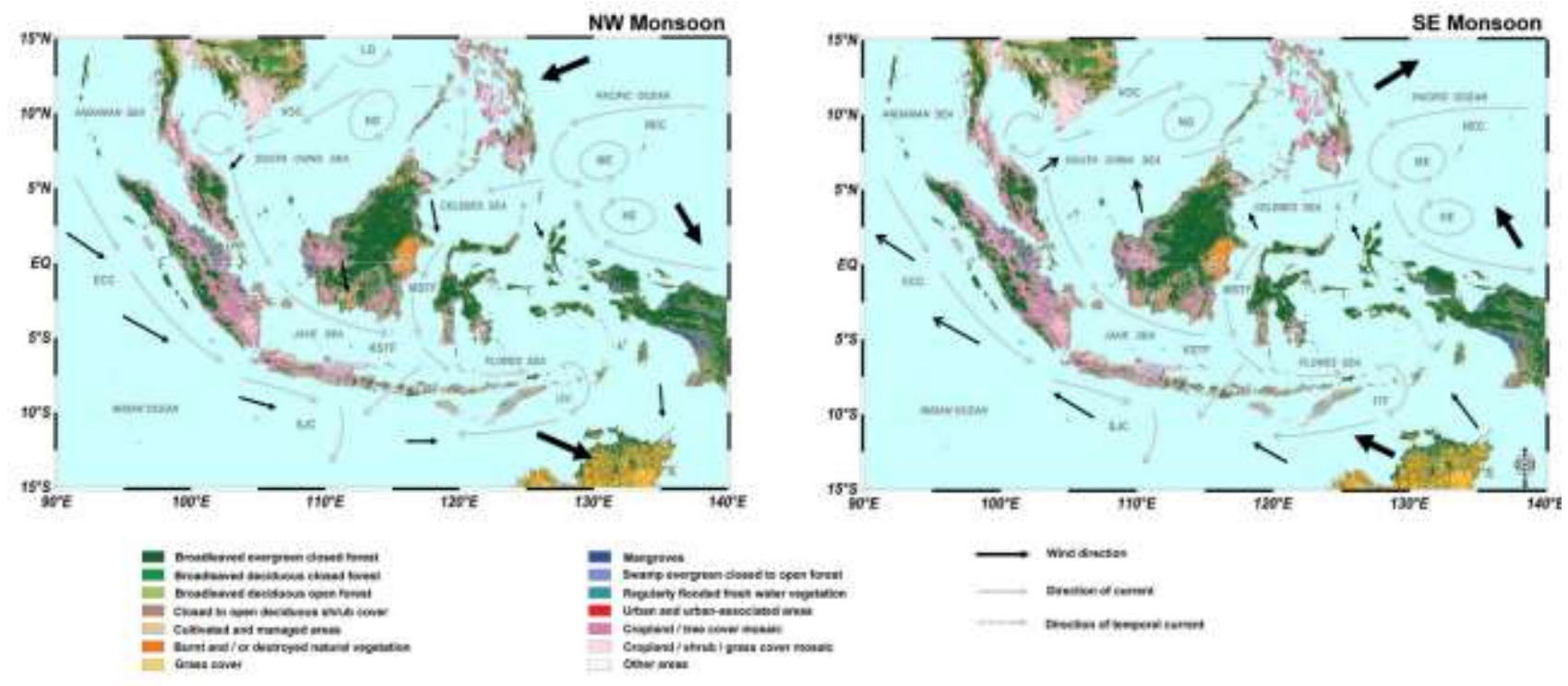

Fig.4.2.Main types of modern vegetation in Indonesia (after Stibig, et al., 2002), principal oceanic currents and winds in the source area during the NW (left picture) and SE monsoon (right picture) with the position of the sediment cores 1412-19 and 1609-30 (red dots). Patterns of winds are drawn following Black (2002) and P. Wang. et al. (2000, 2005); directions of currents are modified after Schott and McCreary (2001), Zheng et al. (2006), Andruleit (2007), Fang et al. (2009). The abbreviations stand for the following: ITF, Indonesian Throughflow; ECC, Equatorial Counter Current; KSTF, Karimata Strait Throughflow; LG, Luzon Gyre; MSTF, Makassar Strait Throughflow; NG, Nansha Gyre; VOC, Vietnam Offshore Current.

\subsubsection{System of marine currents}

As a result of the shallowness of the basin, the water column of the Java Sea is well mixed. The main driving force of the water current direction is the prevailing wind (Writky, 1961). During the time period covering the NW monsoon (Fig. 4.2) the main currents have an eastern direction. Waters of the Java Sea are appended by the Karimata Strait Throughflow (KSTF) which has its origin in the S China Sea. In the most eastern part of the Java Sea, additional inflow comes from the north by the Makassar Strait Throughflow (MTSF). These waters mix with the KMST and leave the basin through the Flores Sea. During the period of SE 
monsoon (May-September) its direction changes and waters flow in the western direction (Fig. 4.2). Waters of the Java Sea are then formed by MTSF waters which leave the Sea through the Karimata Strait. During the intermediate months (April and October), the current direction changes and numerous eddies are formed. In these months the currents off the coast of Java generally flow in easterly direction, whereas at the same time a western current is present off the coast of Kalimantan (Genia et al., 2007). The Indonesian Throughflow (ITF) flows through the Lombok Strait and neutralizes lower sea surface temperatures off Java during the upwelling season (Romero et al., 2009).

\subsubsection{Vegetation}

The vegetation of Java and Kalimantan is represented by mangrove, lowland rainforests, including peat swamp and freshwater swamp forests, submontane (1000 - $1500 \mathrm{~m})$, lower montane $(1500-2400 \mathrm{~m})$ and upper montane (2400 - 3000 m) forest (Fig. 4.2) (Backer and van den Brink, 1965; Van Steens, 1984; Whitten et al., 1996; Burbidge, 1960; Collins et al., 1991; MacKinnon et al., 1997). Mangroves are composed mainly of Avicennia (Acanthaceae), Nypa (Arecaceae), Rhizophoraceae and Sonneratiaceae. Lowland vegetation is represented by a high-stemmed mesophyll forest with closed canopy and incredible floristic diversity with Alchornea (Euphorbiaceae), Elaeocarpus (Elaeocarpaceae), Moraceae and Urticaceae (Backer and van den Brink, 1965; Van Steenis, 1984). At the forest edges and in canopy openings light-demanding Acalypha (Euphorbiaceae), Ficus (Moraceae), Macaranga, Mallotus (Euphorbiaceae), Trema (Cannabaceae), Pandanus (Pandanaceae) and other pioneer taxa can be found (Van Steens, 1984; Whitmore, 1984). Submontane forest is dominated by Fagaceae: Castanopsis, Lithocarpus and Quercus with some Myrtaceae and Myrica (Myricaceae). Montane forest is characterised by relatively strong vertical zonation and represented by Engelhardia (Juglandaceae), Podocarpaceae (Dacrycarpus, Podocarpus), Ericaceae, Myrica (Myricaceae), Myrinaceae and Weinmannia (Cunoniaceae) (Van Steenis, 1984; Kaars and Dam, 1995).

Most of Kalimantan is still covered by species-rich closed-canopy forests with high endemism and very high productivity (e.g. Ashton, 1982). The natural forests in the lowlands of Kalimantan are grouped by Mackinnon et al. (1997) mixed Dipterocarpus forest, semi-evergreen rainforest, moist deciduous and dry deciduous forests. The differences are mostly related to the seasonality of rainfall. The peat swamp vegetation association is generally similar to lowland dipterocarp forest, which has a bit lower plant diversity (Barber et al., 2002). These forests are dominated by Gonystylus (Thymelaeaceae), Dactylocladus (Crypteroniaceae), Shorea (Dipterocarpaceae), diverse Anacardiaceae, Euphorbiaceae and Engelhardia with some Ilex and opportunistic taxa like Trema, Terminalia (Combretaceae), Pandanus (Pandanaceae) (Mackinnon et al. (1997). There are also small areas of extrazonal forests on limestone and some communities in littoral areas, where Casuarina (Casuarinaceae) occurs (Whitmore, 1990). Extensive mangroves occur along the coasts lines, in deltas of big rivers and estuaries (Collins et al., 1991; MacKinnon et al., 1997).

Unlike in Kalimantan, the original vegetation of Java has been strongly changed by human activity during the last few hundred years. Only a few remote spots and tops of mountains still bear the original vegetation on Java (Stuijts, 1993); small areas of secondary forests occur in the lowlands (Whitten et al., 1996). Periodical droughts and connected with them fires together with excessive logging, agriculture (e.g. rice and maize cultivation, oil palm plantations) and aquaculture cause a problem of deforestation. The area covered by mangroves on Java has been strongly reduced as well.

\subsection{Material and methods}

This study is based on the analysis of two sediment cores obtained from the Java Sea. Core 1412-19 (3.258 S; $110.649833^{\circ} \mathrm{E}$, water depth $9.7 \mathrm{~m}$; length $91.5 \mathrm{~cm}$ ) has been retrieved about $25 \mathrm{~km}$ off the distal end of 
the Jelai River plume ( $\mathrm{S}$ coast of Kalimantan, Fig. 4.1). The length of the river is ca $100 \mathrm{~km}$ and the drainage area is about $300 \mathrm{~km}^{2}$ (http://wetlands.or.id/). Sediments of the core consist of homogeneous pale-brown clayish silt with numerous black particles. By visual observation no clear stratification or lamination can be observed. The sample resolution in the upper $30 \mathrm{~cm}$ and lower $11 \mathrm{~cm}$ of the core is one sample per every 2 $\mathrm{cm}$. In the intermediate part $(30-80 \mathrm{~cm})$ it is one sample per every $5 \mathrm{~cm}$.

The core $1609-30\left(6.497147^{\circ} \mathrm{S} ; 112.475369^{\circ} \mathrm{E}\right.$, water depth $56.3 \mathrm{~m}$; length $\left.96 \mathrm{~cm}\right)$ has been collected about $50 \mathrm{~km}$ off the Solo River mouth (E coast of Java, Fig. 4.1). The length of the river is ca $600 \mathrm{~km}$ and the drainage area is $15,400 \mathrm{~km}^{2}$ (Whitten, 1996). The core consists of dark grey to pale-grey silt sediments containing fragments of shells and coarse siliceous material. The lower part between 70 and $96 \mathrm{~cm}$ of the core is more compact than the upper part. Sampling resolution is one sample per every $5 \mathrm{~cm}$ along the core. The upper $20 \mathrm{~cm}$ and the lower $5 \mathrm{~cm}$ where sampled every $1 \mathrm{~cm}$.

\subsubsection{Age control}

The age control for both investigated sediment cores is based on accelerator mass spectrometry (AMS) radiocarbon dating that has been conducted at the Keck Carbon Cycle Accelerator Mass Spectrometry Facility at the University of California in Irvine, USA. The results have been corrected for isotopic fractionation with $\delta^{13} \mathrm{C}$ values according to the method described by Stuiver and Polach (1977) and calibrated to calendar years with the online version of CALIB 7, marine 13 (Stuiver and Reimer, 1993) considering a reservoir age of $90 \mathrm{yr}$ (Southon et al., 2002). Only the two youngest ages in core 1412-19, being outside the range of the CALIB 7 calibration, have been calibrated using the CALPAL2007-Hulu calibration (Weninger et al., 2007). For each core five radiocarbon dates obtained from bivalve shells or from mixed benthic foraminifera are available (Table 4.1). The ages of the record are discussed in this work as time-windows in order to minimize the error due to the uncertainty of the age-depth model.

Table 4.1. Radiocarbon dates obtained from the two sediment cores 1412-19 and 1609-30 retrieved from the Java Sea. * The shell dated is considered to be reworked and, therefore, the date was omitted.

\begin{tabular}{|l|l|l|l|l|l|l|l|}
\hline Core & $\begin{array}{l}\text { Depth, } \\
\text { cm }\end{array}$ & $\begin{array}{l}\text { UCIAMS } \\
\text { lab no. }\end{array}$ & $\begin{array}{l}\text { 14C age, } \\
\text { yr BP }\end{array}$ & \pm error & $\begin{array}{l}\text { calendar age, } \\
\text { al yr BP } \\
(\mathrm{P}=1950)\end{array}$ & $\begin{array}{l}2 \sigma \text { range, } \\
-95 \%\end{array}$ & $\begin{array}{l}\text { dated } \\
\text { material }\end{array}$ \\
\hline $1412-19$ & $0-1$ & 145981 & 515 & 25 & -23 & -23 & bivalve shell \\
\hline $1412-19$ & $16-17$ & 123477 & 530 & 20 & -18 & -18 & bivalve shell \\
\hline $1412-19$ & $41-42$ & 145980 & 730 & 25 & 288 & $172-411$ & bivalve shell \\
\hline $1412-19$ & $71-72^{*}$ & 145982 & 1890 & 25 & 1344 & $1260-1470$ & bivalve shell \\
\hline $1412-19$ & $79-80$ & 123478 & 1520 & 20 & 979 & $888-1098$ & bivalve shell \\
\hline
\end{tabular}

\begin{tabular}{|l|l|l|l|l|l|l|l|}
\hline $1609-30$ & $1-2$ & 133823 & 790 & 20 & 351 & $266-444$ & bivalve shell \\
\hline $1609-30$ & $7-8$ & 123491 & 1365 & 20 & 821 & $717-916$ & $\begin{array}{l}\text { benthic } \\
\text { foraminifera }\end{array}$ \\
\hline $1609-30$ & $41-42$ & 133824 & 2120 & 20 & 1598 & $1484-1721$ & $\begin{array}{l}\text { benthic } \\
\text { foraminifera }\end{array}$ \\
\hline $1609-30$ & $77-78$ & 133825 & 2815 & 25 & 2436 & $2315-2613$ & $\begin{array}{l}\text { benthic } \\
\text { foraminifera }\end{array}$ \\
\hline $1609-30$ & $90-91$ & 123492 & 3500 & 20 & 3279 & $3153-3388$ & $\begin{array}{l}\text { benthic } \\
\text { foraminifera }\end{array}$ \\
\hline
\end{tabular}

4.3.2. Pollen and dinocyst analysis 
For pollen, spore and dinoflagellate cyst analysis $3 \mathrm{~g}$ of dry sediment was taken. Samples were prepared following the standard palynological technique as is described by Faegri and Iversen (1975) and Zonneveld et al. (2009). Cold hydrochloric acid ( $\mathrm{HCl} 10 \%)$ was added for the removal of carbonate in amounts depending on the intensity of the reaction. Siliceous component of the samples was removed by adding of hydrofluoric acid (HF 72\%). To remove all macro-remains, sieving at $150 \mu \mathrm{m}$ sieve was applied. To remove small organic particles the samples were sieved over a $10 \mu \mathrm{m}$ nylon filter. In order to avoid damage to the dinocysts, no acetolysis and other oxidation treatments were applied. The samples were mounted in glycerine gelatine and examined under the light microscope at a magnification of 400 and 1000 times.

Per sample, 200 pollen grains and 100 dinocysts were counted. Relative abundances of taxa were calculated on the basis of the total sum of pollen grains and sum of dinocysts respectively, excluding indeterminable grains/cysts, fern spores, and green algae. To determine pollen/spores/dinocyst concentration (in grains/spores/cells per $\mathrm{ml}$ ) one Lycopodium clavatum tablet (Stockmarr, 1971) with known number of spores $(20,848 \pm 1546)$ was added to each sample before processing. All identified pollen and cyst types were photographed with a digital camera. Photos of identified pollen and spores are available on request at the Department of Palynology and Climate Dynamics (University of Göttingen, Germany).

\subsubsection{Pollen taxonomy and groups}

Taxonomy of pollen and spores is based on Moore and Webb (1978), Wang et al. (1995), Kodela (2006), Fujiki et al. (2005), Stevenson (1998) and Mao et al., (2012), online database "The Australasian Pollen and Spore Atlas" (Weng et al., 2007) as well as on our own pollen reference collection including about 300 Indonesian taxa. Determination of large Poaceae (i.e. Oryza and Zea mays) was based on Chaturvedi et al. (1998), Maloney (1990), Tweddle et al. (2005) and Atahan et al. (2008).

Pollen taxa are divided into 6 groups according to the main vegetation types of Java and Kalimantan, i.e. mangrove, lowland rainforest, submontane and montane forest. Additionally, sums of herbaceous taxa and sum of Pteridophyta was calculated.

\subsubsection{Dinoflagellate cyst taxonomy and groups}

Dinocysts were identified based on Matsuoka (2009), Fensome et al. (1993), Zonneveld (1997), Zonneveld et al. (2013), Zonneveld and Pospelova (2015, Fensome and Williams (2004), Kawamura (2004). Echinidinium spp. includes all spiny brown cysts that could not be identified on species level. Brigantedinium spp. includes all smooth-walled spherical brown cysts (RBC).

Dinoflagellate cysts are grouped according to their ecological characteristics based on the global geographic distribution (Marret and Zonneveld, 2013). The post-depositional degradation of dinoflagellate cysts is estimated using the dinoflagellate degradation index "kt" according to Versteegh and Zonneveld (2002) and Liang et al. (2011). Separation between phototrophic (PT), heterotrophic (HT), oxidation-sensitive (OST) and oxidation resistant (ORT) dinocyst types is based on Zonneveld et al., 2008 and Mertens et al. (2009). Identification of tropical (TT), temperature tolerant (TTT), fully marine (FMT) and low salinity tolerant (LST) dinocyst types is based on Zonneveld et al. (2013).

\subsubsection{Pollen and dinocyst diagrams}

The percentages diagrams for pollen and spores are based on the total pollen sum which includes all pollen types and excludes indeterminate pollen and fern spores. Relative abundances of ferns are calculated on the base of total pollen sum. The percentage diagrams for dinocysts are based on the total sum of all identified cysts. Pollen, spore and dinocyst types contributing less than $2 \%$ on average are not included into the 
diagrams. The whole lists of pollen/spore and dinocyst types as well as raw counts are available under the name of the corresponding author at the PANGAEA server (www.pangaea.de). Pollen and dinocyst diagrams (Figs. 4.4-4.6) were prepared using TILIA and TILIAGRAPH software (Grimm, 1990). The diagrams are subdivided into local zones, which were established visually by comparing dynamics of the principal taxa and groups, supported by the results of the depth-constrained cluster analysis by sum-of-squares implemented with CONISS for TILIA (Grimm, 1987).

\subsubsection{Microcharcoal analysis}

For microcharcoal analysis all black and completely opaque with sharp edges and a size 10-150 $\mu \mathrm{m}$ were counted. The total of at least 200 items was counted per unit of volume, as it was recommended by Finsinger and Tinner (2005). Microcharcoal concentrations were plotted against depth and accompany the pollen diagrams of the respective marine core.

\subsubsection{Multivariate data analysis}

To study the ecological structure of the datasets of both pollen and dinocysts, two multivariate ordination analyses based on relative abundance of pollen and dinocysts have been carried out, using the CANOCO 5 and CanoDraw software package (ter Braak and Šmilauer, 1997; Lepš and Šmilauer, 2003, Šmilauer and Lepš, 2014). After a detrended correspondence analysis (DCA; Hill and Gauch, 1980) which had revealed a gradient length of 1.3 (core 1412-19) and 2.0 (core 1609-30) for the first axis, principle component analysis (PCA) was applied as recommended by Lepš and Šmilauer (2003) for data sets with short environmental gradients. All taxonomic data were standardized and logarithmic transformed.

To obtain insight into the similarity/dissimilarity of the pollen and dinocyst datasets and to estimate how well the two datasets match to each other in terms of compositional gradients, Procrustes analysis (PA, Jackson, 1995) has been applied using the CANOCO 5 software package (Gower, 1975; Peres-Neto and Jackson, 2001; Šmilauer and Lepš, 2014). The similar ordination methods for both data-sets were used to overcome the problem that differences detected by PA may result from using different ordination methods. The PA errors reflecting the difference in sample ordination scores are depicted with arrows. The length of the arrows indicate the magnitude of similarity between paired ordination diagrams, i.e. sample scores of the pollen and dinocyst analyses with short arrows suggesting high similarity between the outcome of both PCA and long arrows suggesting low similarity.

\subsection{Results}

\subsubsection{Cores stratigraphy}

The age models for both cores are based on five radiocarbon dates each (Table 4.1). For core 1412-19 the uppermost three dates show a coherent sequence of increasing age with depth. However, the two ages obtained further downcore $(71-72 \mathrm{~cm}$ and $79-80 \mathrm{~cm}$, respectively) are reversed. Both ages are obtained on single bivalve shells. However, as reworking can put older material in a younger sequence but not vice versa, we consider the shell dated taken from $71-72 \mathrm{~cm}$ core depth to be reworked and, thus, omitted it from the further interpretation. The age difference of eight years between the two uppermost dates $(0-1 \mathrm{~cm}$ and $16-$ $17 \mathrm{~cm}$ core depth) places this entire uppermost section of the core into the late $20^{\text {th }}$ century. Consequently, the final age model for this core is based on the three dates in $16-17 \mathrm{~cm}, 41-42 \mathrm{~cm}$ and $79-80 \mathrm{~cm}$ core depth giving it a stratigraphic range covering the last $1200 \mathrm{yr}$ with sedimentation rates varying between 5 to $8 \mathrm{~cm}$ 
Table 4.2. Core 1412-19: Results of pollen, dinocyst and microcharcoal analysis.

\begin{tabular}{|c|c|c|c|c|}
\hline $\begin{array}{c}\text { Palynological } \\
\text { zone, age } \\
\text { (cal yr BP), } \\
\text { core depth } \\
\text { (cm) }\end{array}$ & Pollen zone characteristics & $\begin{array}{c}\text { Dinocyst } \\
\text { zone, age } \\
\text { (cal yr BP), } \\
\text { core depth } \\
\text { (cm) }\end{array}$ & Dinocyst zone characteristics & $\begin{array}{c}\text { Micro-charcoal } \\
\text { concentrations, } \\
\sim \text { particles } / \mathrm{g}\end{array}$ \\
\hline $\begin{array}{l}\text { KP-1, } \\
1200-910, \\
91-75\end{array}$ & $\begin{array}{l}\text { Mangrove pollen form about } 34 \% \text { of the total pollen sum with } \sim 29 \% \text { of } \\
\text { Rhizophora and } \sim 4 \% \text { of Avicennia. Lowland rainforest (up to } 29 \%) \text { is the most } \\
\text { diverse group }(17 \text { pollen types) and is dominated by pollen of } \\
\text { Macaranga/Mallotus }(\sim 11 \%) \text {, Acalypha ( }(7 \%) \text {, Moraceae/Urticaceae }(\sim 4 \%) \text {. } \\
\text { Dipterocarpaceae form up to } 5 \%) \text { which is their max. Submontane forest } \\
\text { contributes } \sim 18 \% \text {; it is represented by } 11 \text { taxa and strongly dominated by } \\
\text { Lithocarpus/Castanopsis }(\sim 11 \%) \text {. Montane taxa add } \sim 5 \% \text { being represented } \\
\text { mainly by Podocarpus and Dacrycarpus (about } 4 \% \text { together). Herbs are } \sim 14 \% \\
\text { with Poaceae }(\sim 9 \%) \text { contributing the most. The values of Pteridophyta are } \\
\sim 39 \% \text {.Pollen concentration is about } 1053 \text { grains/g; spore concentration is about } \\
893 \text { spores/g. }\end{array}$ & $\begin{array}{l}\text { KD-1, } \\
1200-980, \\
91-80\end{array}$ & $\begin{array}{l}\text { Almost equal contribution of PT ( } \sim 45 \% \text { of total dinocyst sum) and HT }(\sim 55 \%) \text {. Low } \\
\text { values of RBC }(\sim 25 \%) \text {, very low values of Lingulodinium machaerophorum }(\sim 1.5 \%) \text { and } \\
\text { Nematosphaeropsis labyrinthus }(\sim 1.3 \%) \text {. The group of PT is mainly represented by } \\
\text { Operculodinium israelianum }(\sim 9 \%) \text {, Spiniferites spp. }(\sim 8 \%) \text {, Spiniferites ramosus }(\sim 6 \%) \\
\text { and Spiniferites mirabilis }(\sim 6 \%) \text {. Among HT spiny brown cysts, Echinidinium granulatum } \\
(\sim 9 \%) \text {, Echinidinium delicatum }(\sim 7 \%) \text { and Echinidinium zonneveldiae }(\sim 6 \%) \text { are the most } \\
\text { abundant. Relative abundance of cysts of Polykrikos kofoidii is about } 4 \% \text {. Contribution of } \\
\text { TT is about } 23 \% \text {, while TTT form up to } 15 \% \text {. Percentages of FMT are about } 30 \% \text { and } \\
\text { percentages of LST } \sim 9 \% \text {. OST }(\sim 55 \%) \text { dominate over ORT }(\sim 3 \%) \text {. Average dinocyst } \\
\text { concentration is } \sim 1030 \text { cysts/g. }\end{array}$ & 78 \\
\hline $\begin{array}{l}\text { KP-2, } \\
910--20, \\
75-15\end{array}$ & $\begin{array}{l}\text { Average values of mangrove declined to about } 21 \% \text {. Lowland rainforest taxa } \\
\text { increase both their sum }(\sim 38 \%) \text { and diversity }(28 \text { taxa). Values of } \\
\text { Macaranga/Mallotus increase from about } 14 \% \text { at the beginning of the zone }(75-60 \\
\mathrm{cm}) \text { to } \sim 31 \% \text { at the end }(20-15 \mathrm{~cm}) \text {. Percentages of Moraceae/Urticaceae stay at } \\
\text { about } 3 \% \text {. Submontane forest contributes } \sim 24 \% \text { and is still dominated by } \\
\text { Lithocarpus/Castanopsis }(\sim 16 \%) \text {. Engelhardia is represented by single grains at } \\
\text { the beginning of zone and increase its values up to } 10 \% \text { at the end. Montane taxa } \\
\text { reduce their values from } \sim 5 \%(75-55 \mathrm{~cm}) \text { to } 2 \%(25-15 \mathrm{~cm}) \text {. Percentages of herbs } \\
\text { are } \sim 12 \% \text {. From about } 30-25 \mathrm{~cm} \text { Caryophyllaceae and Asteraceae are constantly } \\
\text { present. At the depth of } 16 \mathrm{~cm} \text { first grain of Oryza type is found. Pteridophyta form } \\
\text { around } 58 \% \text {. Pollen concentration is about } 1150 \text { grains } / \mathrm{g} \text {, spore concentration is } \\
\text { about } 670 \text { spores } / \mathrm{g} \text {. } \\
\text { Zone KP-2 has been divided into two subzones. Subzone KP- } 2 \mathrm{a}(50-15 \mathrm{~cm}) \text { is } \\
\text { clearly separated from subzone KP-2b ( } 75-50 \mathrm{~cm}) \text { by the decrease of } \\
\text { Dipterocarpaceae, Agathis, Allophyllus and Dacrycarpus pollen, by more frequent } \\
\text { findings of Quercus and by increasing values of Acalypha (up to } \sim 7 \%) \text { and Trema } \\
\text { (up to } 4 \%) \text {. }\end{array}$ & $\begin{array}{l}\text { KD-2, } \\
980-10, \\
80-20\end{array}$ & $\begin{array}{l}\text { Between zones KD-1 and KD-2 a characteristic decrease in PT }(\sim 34 \%) \text { occurs. By } \\
\text { contrast, values of Brigantedinium spp. reached their highest amount }(\sim 50 \%) \text {. } \\
\text { Lingulodinium machaerophorum with reduced processies and Votadinium calvum are } \\
\text { registered. The group of PT is dominated by Spiniferites spp. }(\sim 6 \%) \text { with some } \\
\text { contribution of S. ramosus and S. pachydermus (both } \sim 5 \%) \text {. Values of Operculodinium } \\
\text { israelianum decreased to } \sim 4 \% \text {, values of } O \text {. centrocarpum fluctuate between } 1 \% \text { and } 3 \% \text {. } \\
\text { Percentages of L. machaerophorum are about } 3 \% \text {, while concentrations of } \\
\text { Nematosphaeropsis labyrinthus are similar compared to the previous zone. Contribution of } \\
\text { HT is about } 66 \% \text {. Percentages of all Echinidinium species decrease markedly. Relative } \\
\text { abundances of cysts of Polykrikos kofoidii are a bit higher than in the previous zone }(\sim 5 \%) \text {. } \\
\text { Values of TT are about } 15 \% \text {; TT contribute } \sim 8 \% \text {. Percentages of FMT are about } \sim 18 \% \text {. } \\
\text { Rate of OST increased up to } \sim 66 \% \text {, while the rate of ORT stays about the same }(\sim 3 \%) \text {. } \\
\text { Dinocyst concentration is about } 1170 \text { cysts/g. }\end{array}$ & 240 \\
\hline $\begin{array}{l}\text { KP-3, } \\
-20--23, \\
15-0\end{array}$ & $\begin{array}{l}\text { The values of mangrove decrease to about } 10 \% \text { with up to } \sim 9 \% \text { of Rhizophora. } \\
\text { Lowland rainforest taxa remains the highest contributing }(\sim 55 \%) \text { and most diverse } \\
\text { group ( } 21 \text { pollen types) dominated by Macaranga/Mallotus }(\sim 30 \%) \text {. Acalypha } \\
\text { forms } \sim 10 \% \text { and Moraceae/Urticaceae } \sim 6 \% \text {. Trema reaches its max. ( } \sim 5 \%) \text {. } \\
\text { Submontane forest is dominated by Engelhardia }(\sim 7 \%) \text {. Herbs are at their } \\
\text { maximum }(\sim 19 \%) \text { and composed by } 11 \text { taxa with Poaceae making up to } 12 \% \text {. } \\
\text { Single grains of Oryza type, Zea mays and Pinus are found. Montane taxa } \\
\text { contribute } \sim 3 \% \text { only. The values of Pteridophyta have their lowest rate } \\
(\sim 46 \%) \text {.Pollen concentration is about } 1230 \text { grains/g; spore concentration is } \sim 560 \\
\text { spores/g. }\end{array}$ & $\begin{array}{l}\text { KD-3, } \\
10--23, \\
20-0\end{array}$ & $\begin{array}{l}\text { High percentages of Lingulodinium machaerophorum }(\sim 8 \%), \text { Nematosphaeropsis } \\
\text { labyrinthus }(\sim 5 \%) \text {, cysts of Polykrikos kofoidii }(\sim 4 \%) \text { and increased relative abundances of } \\
\text { Selenopemphix nephroides }(\sim 4 \%) \text { and cysts of Polykrikos schwartziii }(\sim 2 \%) \text {. Cysts of the } \\
\text { Impagidinium group occur regularly in this zone unlike in the two previous zones. Rates of } \\
\text { PT and HT are almost equal (both about 50\%). PT are mainly represented by Spiniferites } \\
\text { spp. }(\sim 9 \%) \text { and Operculodinium israelianum }(\sim 7 \%) \text {. Among HT, Brigantedinium spp. } \\
\text { contributing } \sim 28 \% \text { and Echinidinium transparantum makes up } \sim 6 \% \text {. TT and TTT } \\
\text { contribute } \sim 19 \% \text { and } 10 \% \text {, respectively. Percentages of FMT are about } 19 \% \text {. Abundances } \\
\text { of OST }(\sim 48 \%) \text { decrease in contrast to ORT cysts which increase }(\sim 9 \%) \text {. Dinocyst } \\
\text { concentration is the highest for the entire record }(\sim 1300 \text { cysts } / g) \text {. }\end{array}$ & 605 \\
\hline
\end{tabular}




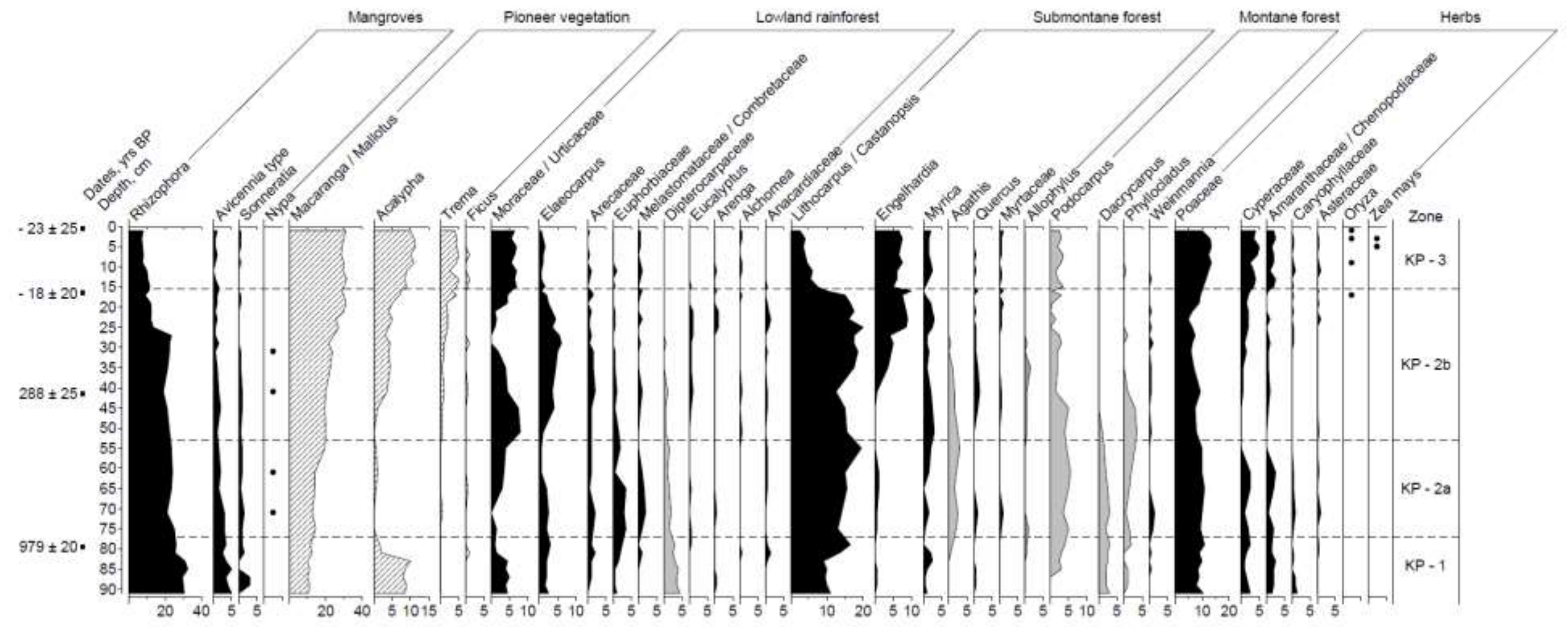

Fig. 4.3. Pollen diagram for the core 1412-19 showing relative frequencies of selected pollen and spore types, main vegetation groups and concentration. Pollen types of pioneer taxa have striped profiles; pollen types of timber tree taxa have grey profiles (beginning). 


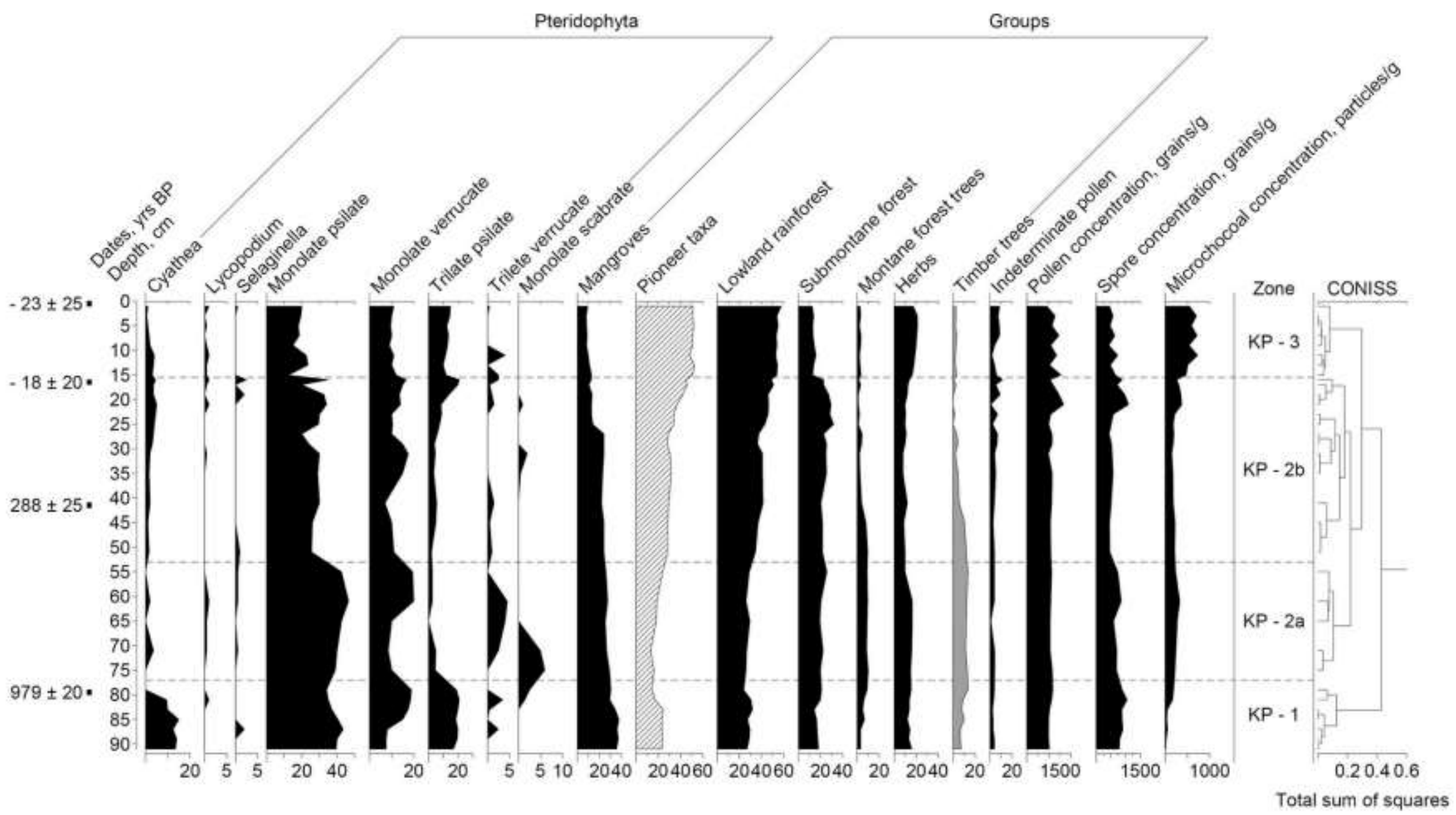

Fig. 4.3. Pollen diagram for the core 1412-19 showing relative frequencies of selected pollen and spore types, main vegetation groups and concentration. Pollen types of pioneer taxa have striped profiles; pollen types of timber tree taxa have grey profiles (end). 
per century. For core 1609-30 the age/depth relationship shows a coherent sequence of increasing age with the depth (Table 4.1). This core covers stratigraphically the last $3500 \mathrm{yr}$ with sedimentation rates varying between 1 and $4 \mathrm{~cm}$ per century. For both cores, age assignments between the considered dates are based on linear interpolation, with extrapolation beneath the oldest obtained ages.

\subsubsection{Pollen stratigraphy}

Pollen diagrams for the cores 1412-19 and 1609-30 are presented in Fig. 4.3 and 4.4, respectively. In samples from S Kalimantan (core 1412-19), 71 pollen types of pollen, 8 types of fern spores were identified. Descriptions of 4 local pollen zones established based on the results of the constrained cluster analysis as well as dynamics of the key pollen/spore types are presented in the Table 4.2.

In samples from E Java (core 1609-30), 73 pollen types, 7 types of fern spores and 29 types of dinoflagellate cysts were recorded. Additionally, 12 indeterminate pollen types and 10 indeterminate spore types were distinguished. The descriptions of 3 local pollen zones are given in the Table 4.3.

The pollen and spore preservation is sufficient and relatively stable throughout both records. Percentages of fern spores in both records prevail over percentages of pollen, while the arboreal sum prevails over the sum of herbs. The most abundant pollen types in both records relate to lowland rainforest. Signals from upper montane forest were generally weak.

\subsubsection{Dinocyst stratigraphy}

For both cores, dinocyst stratigraphy almost repeats a pollen-based one. Dinocyst diagrams for the cores 1412-19 and 1609-30 are presented in Fig. 4.5 and 4.6 respectively. The preservation state of the pollen/spores and dinocysts in both cores is good, although the proportions of damaged and broken cysts increase with depth. For the core 1412-19 kt varied from 1.0 to 2.9, for the core 1609-30 from 0.1 to 2.7. HT prevailed in both records, RBC mainly. As for PT, Spiniferitus ssp. and Echinidinium ssp. are common for the core 1412-19, while for the core 1609-30 Echinidinium granulatum and Operculodinium israelianum are frequent. The descriptions of dinocyst zones are provided given in the tables 4.2 (core 1412-19) and 4.3 (core 1609-30).

\subsubsection{Results of multivariate data analysis}

The PCA revealed the relationships between samples and taxa (Fig. 4.7). Only taxa with the highest explanatory values are displayed. For both cores, the PCA diagrams (Fig. 4.8) show a clear division of the samples into two groups: left and right parts of the plot. Samples that are characterized by high relative abundances of primary forest pollen types (i.e. Agathis, Allophylus, Dacrycarpus, Dacrydium, Dipterocarpaceae, Phyllocladus and Podocarpus) occupy the left sector. In contrast, the right sector comprises samples that are positively correlated with high the percentages of pioneer taxa, such as Acalypha, Ficus, Macaranga/Mallotus, Trema and Pandanus. In core 1412-19, these samples belong to the depths below $25 \mathrm{~cm}$ (upper part of pollen subzone KP-2b and zone KP-3). In case of core 1609-30, samples positively correlated with secondary taxa belong to pollen zone JP-4, which is the uppermost one.

Results of the PCA of the dinocyst data are depicted in Fig. 4.9. Cosmopolitan dinocyst species that are characteristically present in eutrophic waters (i.e. cysts of Polykrikos schwartzii, P. kofoidii, Lingulodinium machaerophorum, Nematosphaeropsis labyrinthus, Selenopemphix nephroides) are ordinated for both cores in the right sector of the diagram comparable to the ordination scores of the pioneer vegetation pollen types (Fig. 4.9). 


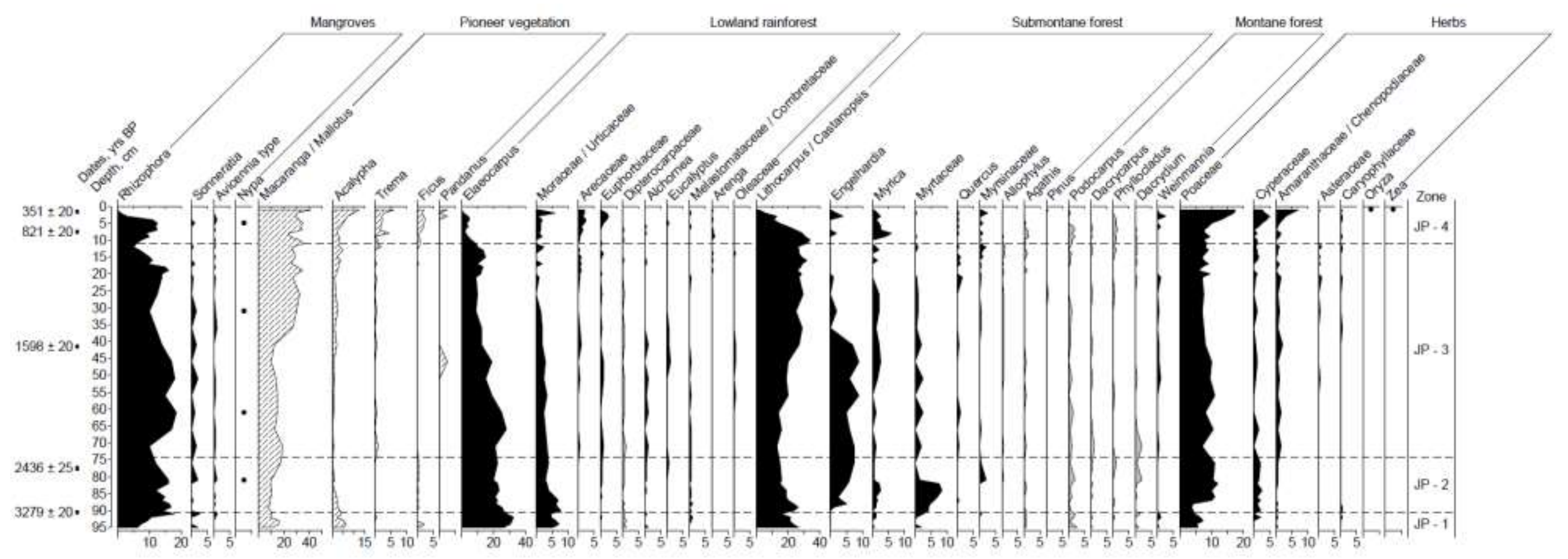

Fig. 4.4. Pollen diagram for the core 1609-30 showing relative frequencies of selected pollen and spore types, main vegetation groups and concentration. Pollen types of pioneer taxa have striped profiles; pollen types of timber tree taxa have grey profiles (beginning). 


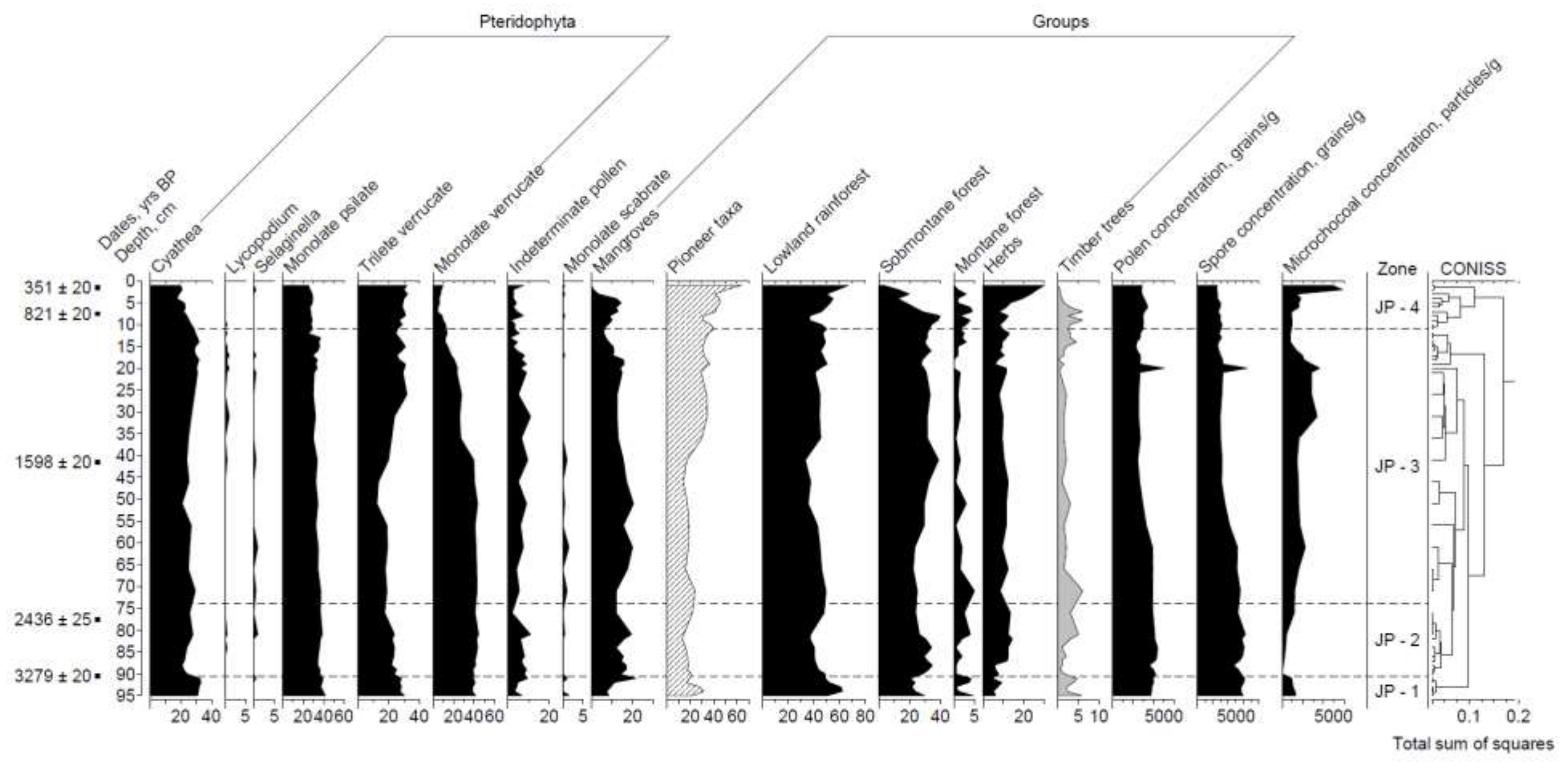

Fig. 4.4. Pollen diagram for the core 1609-30 showing relative frequencies of selected pollen and spore types, main vegetation groups and concentration. Pollen types of pioneer taxa have striped profiles; pollen types of timber tree taxa have grey profiles (end). 
The PA comparison of the sample ordination scores of both PCAs reveals a high similarity between both datasets with similar samples ordinated on highly similar positions in both PCA spaces (Fig. 4.9). Sample scores of both PCAs show a very strong correlation of about 0.98 and disagreement measure value of about 0.004. The small PA errors reflected by the length of the short arrows indicate a high magnitude of similarity between paired diagrams. Based on PA, the differences between the results of PCA for pollen and dinocyst datasets collected off Kalimantan as well as off Java can be described as minimal.

\subsection{Interpretation and discussion}

The combination of pollen, spore and dinocyst data allows the reconstruction of changes on land and in the marine realm during the last 3500 years. For both core sites, the PCA applied to pollen data (Fig. 4.8) shows clear stratification: the lowermost samples contain predominantly pollen of timber tree taxa, whereas the uppermost samples contain greater amounts of pollen of the pioneer trees. The high similarity of the PCA outcomes for the pollen and dinocyst records (Fig. 4.8-4.9) from both locations suggest that changes in the terrestrial and marine assemblages are influenced by similar driving mechanisms. This is also reflected in the relatively uniform separation of samples in the zones as a result of the depth-constrained cluster analyses CONISS. These driving mechanisms may include both climatic and anthropogenic induced factors.

\subsubsection{Pollen spectra and their relations with the source vegetation}

Pollen assemblages from core 1412-19, S Kalimantan, show more diverse arboreal flora (29 woody taxa) with higher values for lowland trees and lower values for herbs than those from core 1609-30, E Java (22 woody taxa). Pollen can be transported to these locations by either aeolian or fluvial transport. Long distance aeolian transport may contribute, for instance, to the values of vesiculate pollen of montane coniferous taxa in marine sediments, e.g. Dacrycarpus, Dacrydium, Podocarpus and Phyllocladus (Heusser and Balsam, 1977; Heusser, 1988; Sun, 1999). For both sites, wind patterns are controlled by the monsoonal system and are very similar as wind directions are synchronous at both locations. Consequently, differences in wind directions cannot account for the different pollen assemblages in the two core sites.

The main river systems that discharge in the vicinity of the core sites are the River Jelai in Kalimantan and the River Solo with its tributary the Dengkeng in Java. The River Jelai originates in the Schwaner Mountains that are situated on the border between West Kalimantan and Central Kalimantan and have altitudes from $150 \mathrm{~m}$ up to $2278 \mathrm{~m}$ above sea level. The River Solo also has its sources in the high mountains, namely the volcano of Mount Lawu (3265 m) and Mount Kidul (700 m in average). The Dengkeng River starts in Mount Merapi (2800 m, Whitten et al., 1996, http://wetlands.or.id/). These settings allow to expect to some extend high values of montane taxa in the pollen assemblages. However, the montane vegetation in $\mathrm{E}$ Java, where annual droughts take place (Stuijts, 1993) is regularly affected by fire, both natural and anthropogenic induced, and forest gives way to secondary vegetation and to grasslands (Stuijts, 1993). As a result, montane pollen percentages are lower in the Solo River discharge compared to that of the Jelai River.

For core 1412-19, the pollen associations observed in the upper core samples reflect the modern vegetation in the drainage areas of the Jelai River quite well. Core 1609-30, where the uppermost sample is dated at about $270 \mathrm{cal}$ yr BP, the pollen assemblages are composed of high amounts of pioneer and submontane arboreal taxa as well as of diverse and highly abundant herbs. In Kalimantan where the River Jelai is going through some open areas with shrubs and wide grasslands, particularly on the Central Kalimantan side (http://wetlands.or.id/), sediments are also characterised by relatively high values of herb pollen. Along the eastern bank of the River Jelai, a broad and more or less uninterrupted belt of riparian forest is present. On the western bank, a mosaic of forest and clearings is found. The main water catchment area for this river, however, is the peat swamp forest of Gambut and Mendawai, which is 'the only remaining peat swamp 
Table 4.3. Core 1609-30: Results of pollen, dinocyst and microcharcoal analysis.

\begin{tabular}{|c|c|c|c|c|}
\hline $\begin{array}{l}\text { Palynological } \\
\text { zone, age } \\
\text { (cal yr BP), } \\
\text { core depth } \\
\text { (cm) }\end{array}$ & Pollen zone characteristics & $\begin{array}{c}\text { Dinocyst } \\
\text { zone, age } \\
\text { (cal yr BP), } \\
\text { core depth } \\
\text { (cm) }\end{array}$ & Dinocyst zone characteristics & $\begin{array}{c}\text { Micro-charcoal } \\
\text { concentrations, } \\
\sim \text { particles } / g\end{array}$ \\
\hline $\begin{array}{l}\text { JP-1, } \\
3600-3215 \\
95-89\end{array}$ & $\begin{array}{l}\text { Mangrove pollen forms } \sim 12 \% \text { of pollen sum and is dominated by Rhizophora } \\
(\sim 11 \%) \text {. Lowland rainforest taxa contribute } \sim 54 \% \text { and are composed of } 15 \text { taxa, } \\
\text { mainly of Elaeocarpus }(\sim 29 \%) \text { and Macaranga/Mallotus }(\sim 12 \%) \text {. Values of } \\
\text { Acalypha are } \sim 4 \% \text {. Single grains of Dipterocarpaceae occur. Submontane forest } \\
(\sim 25 \%) \text { is represented mostly by Lithocarpus/Castanopsis }(\sim 22 \%) \text {. Montane taxa } \\
\text { contribute only } 2 \% \text {. Percentages of herbaceous taxa are at their minimal values, } \\
\sim 7 \% \text {. This group is represented by } 5 \text { taxa with Poaceae }(\sim 6 \%) \text { contributing most. } \\
\text { Sum of Pteridophyta spores exceeds pollen sum }(\sim 150 \%) \text {. Pollen concentration is } \\
\sim 3910 \text { grains/g, spore concentration is } \sim 5860 \text { spores/g. }\end{array}$ & $\begin{array}{l}\text { JD-1, } \\
3600-3215, \\
95-89\end{array}$ & $\begin{array}{l}\text { High values of Echinidinium species }(\sim 25 \% \text { of total dinocyst sum), } \\
\text { max.contribution of Echinidinium zonneveldiae }(\sim 6 \%) \text { and low values of } \\
\text { Spiniferites ramosus }(\sim 2 \%) \text {. Values of PT }(\sim 29 \%) \text { are much lower than those of } \\
\text { HT }(\sim 71 \%) \text { and composed mainly of Operculodinium israelianum and } \\
\text { Spiniferites pachydermus (both } \sim 6 \%) \text {. HT are dominated by Brigantedinium } \\
\text { spp. }(\sim 45 \%) \text { and Echinidinium transparantum }(\sim 12 \%) \text {. The amounts of ORT is } \\
\text { very low }(\sim 4 \%) \text {, while those of OST is } \sim 71 \% \text {. TT and TTT contribute } \sim 23 \% \text { and } \\
\sim 77 \% \text {, respectively. Percentages of FMT are } \sim 20 \% \text {; values of } \mathrm{LST} \text { are only } \\
\sim 1 \% \text {. Dinocyst concentration is at its highest value, } \sim 2500 \mathrm{cysts} / \mathrm{g} \text {. }\end{array}$ & 930 \\
\hline $\begin{array}{l}\text { JP-2, } \\
3215-2390, \\
89-75\end{array}$ & $\begin{array}{l}\text { Values of mangrove slightly increase compared to the previous zone }(\sim 15 \%) \text { while } \\
\text { the lowland rainforest taxa decrease values }(\sim 41 \%) \text {. The diversity of pollen types } \\
\text { increase }(21 \text { taxa) at the same time. Amounts of Macaranga/Mallotus decrease } \\
(\sim 10 \%) \text { as well as the values of Elaeocarpus }(\sim 22 \%) \text {. Pollen of } \\
\text { Moraceae/Urticaceae contributes } \sim 5 \% \text { and Acalypha almost vanish at the end of } \\
\text { this zone }(80 \mathrm{~cm}) \text {. Single grains of Dipterocarpaceae occur sporadically. } \\
\text { Contribution of submontane forest taxa is } \sim 30 \% \text { with Lithocarpus/Castanopsis } \\
\text { forming } \sim 19 \% \text { and Myrtaceae up to } \sim 8 \% \text {. Montane taxa are represented mainly by } \\
\text { Podocarpus and Dacrydium. Values of herbs are higher }(\sim 11 \%) \text { due to the higher } \\
\text { contribution of Poaceae }(\sim 9 \%) \text {. Values of Pteridophyta are } \sim 137 \% \text {. Pollen } \\
\text { concentration is } \sim 4060 \text { grains/g; spore concentration is } \sim 5590 \text { spores/g. }\end{array}$ & $\begin{array}{l}\text { JD-2, } \\
3215-2275, \\
89-70\end{array}$ & $\begin{array}{l}\text { Higher values of Brigantedinium spp. ( 49\% of the dinocyst sum) and Spiniferites } \\
\text { ramosus }(\sim 5 \%) \text {. Tuberculodinium vancampoae and Stelladinium stellatum occur } \\
\text { regularly. Relative abundances of Echinidinium zonneveldiae }(\sim 2 \%) \text { decrease. } \\
\text { Abundances of PT form } \sim 32 \% \text { of the association. Relative abundances of } \\
\text { Operculodinium israelianum }(\sim 5 \%) \text { are slightly lower than in the previous zone and } \\
\text { almost equal to the values of Operculodinium centrocarpum. Amounts of Spiniferites } \\
\text { pachydermus remain stable. HT contribute } \sim 68 \% \text { to the association. The brown spiny } \\
\text { cyst group is dominated by Echinidinium transparantum }(\sim 10 \%) \text {. Values of ORT/OST } \\
\text { as well as those of FMT }(\sim 18 \%) / \text { LST }(\sim 2 \%) \text { remain stable. Percentages of TT and TTT } \\
\text { are } \sim 21 \% \text { and } \sim 79 \% \text {, respectively. Dinocyst concentration is a bit lower, } \sim 2310 \text { cysts/g. }\end{array}$ & 350 \\
\hline $\begin{array}{l}\text { JP-3, } \\
2390-870, \\
75-9\end{array}$ & $\begin{array}{l}\text { Pollen of mangrove contributes } \sim 13 \% \text {. Percentages of lowland rainforest are } \\
\text { slightly higher }(\sim 45 \%), \text { taxa diversity increases as well }(26 \text { taxa). Values of } \\
\text { Macaranga/Mallotus are notably higher than before (from } 20 \% \text { to } 25 \%) \text {. Amounts } \\
\text { of Elaeocarpus decline to } \sim 14 \% \text {. Acalypha is absent at the beginning of zone, but } \\
\text { from } 20 \text { to } 10 \mathrm{~cm} \text { it reaches a mean value of } \sim 2 \% \text {. Submontane taxa contribute } \\
\sim 30 \% \text { to the pollen sum. Values of Lithocarpus } / \text { Castanopsis markedly increase } \\
(\sim 25 \%) \text {. Montane taxa are represented by only } \sim 2 \% \text {. Values of herbs are } \sim 10 \% \text {; } \\
\text { values of Poaceae decrease to } \sim 8 \%, \text { other } 10 \text { taxa are of minor contribution. } \\
\text { Amounts of Pteridophyta reduce to } \sim 120 \% \text {. Pollen concentration is } \sim 2960 \\
\text { grains/g; spore concentration is between } \sim 3580 \text { spores/g. }\end{array}$ & $\begin{array}{l}\text { JD -3, } \\
2275-910 \text {, } \\
70-11\end{array}$ & $\begin{array}{l}\text { Contribution of Brigantedinium spp. ( } \sim 6 \%) \text { and Echinidinium transparantum }(\sim 8 \%) \\
\text { decreased, while Spiniferites ramosus and Echinidinium zonneveldiae increase their } \\
\text { values (both up to } \sim 6 \%) \text {. This zone is characterized by the first occurrence of } \\
\text { Bitectatodinium spongium, Lingulodinium machaerophorum, Nematosphaeropsis } \\
\text { labyrinthus, the cysts of Polykrikos kofoidii and Stelladinium robustum type. PT form } \\
\sim 34 \% \text {. Operculodinium israelianum and Operculodinium centrocarpum stay } \\
\text { unchanged. Values of HT are } \sim 66 \% \text {. Amounts of ORT are } \sim 65 \% \text { and amounts of OST } \\
\text { are } \sim 5 \% \text {. Percentages of TT slightly decreased }(\sim 19 \%) \text {, while those of TTT increased } \\
\text { slightly }(\sim 81 \%) \text {. FMT and LST taxa make up } \sim 15 \% \text { and } \sim 2 \% \text { respectively. Dinocyst } \\
\text { concentration decreases further }(\sim 170 \text { cysts/g). }\end{array}$ & 1800 \\
\hline $\begin{array}{l}\text { JP-4, } \\
870-270, \\
9-0\end{array}$ & $\begin{array}{l}\text { Values of mangrove pollen strongly decrease }(\sim 8 \%), \text { while the amounts of } \\
\text { lowland rainforest taxa are much higher }(\sim 50 \%) \text {. Percentages of } \\
\text { Macaranga/Mallotus and Acalypha increase up to } \sim 31 \% \text { and } \sim 6 \% \text {, } \\
\text { respectively, while values of Elaeocarpus dramatically decrease in } \\
\text { comparison to the previous zone }(\sim 3 \%) \text {. Pollen of the Ficus type and } \\
\text { Arecaceae are constantly represented. The portion of submontane taxa } \\
\text { gets reduced }(\sim 22 \%) \text {. Values of Lithocarpus/Castanopsis are } \sim 17 \% \text {. } \\
\text { Montane taxa form only } \sim 2 \% \text {. Percentages of herbs are at the highest } \\
(\sim 18 \%) \quad \text { with Poaceae } \sim 12 \% \text {, Cyperaceae } \sim 2 \% \text { and } \\
\text { Amaranthaceae/Chenopodiaceae }(\sim 2 \%) \text {. The sum of Pteridophyta spores } \\
\text { is the lowest for the entire record, } \sim 91 \% \text {. Pollen concentration is } \sim 3040 \\
\text { grains } / g \text {; spore concentration is } \sim 2770 \text { spores } / g \text {. }\end{array}$ & $\begin{array}{l}\text { JD-4, } \\
910-270, \\
11-0\end{array}$ & $\begin{array}{l}\text { Being very low at the beginning of zone, values of Nematosphaeropsis labyrinthus and } \\
\text { Lingulodinium machaerophorum - (both less than } \sim 1 \%) \text {, reach } \sim 7 \% \text { and } \sim 18 \% \text { at the } \\
\text { top of the core, respectively. PT decreased to } \sim 30 \% \text {; the curve of Operculodinium } \\
\text { israelianum rises }(\sim 8 \%) \text {. Amounts of HT are } \sim 70 \% \text { with Brigantedinium spp. Up to } \\
\sim 44 \% \text { and Echinidinium transparantum } \sim 7 \% \text {. Cysts of Polykrikos kofoidii are regularly } \\
\text { present with the highest values of } \sim 4 \% \text {. Cysts of Polykrikos schwartzii are registered } \\
\text { for the upper most part of this zone. ORT fluctuate around } 70 \% \text { and OST reach their } \\
\text { max. value of } \sim 7 \% \text {. Values of TT are } \sim 20 \% \text {. Amounts of TTT stay without changes } \\
(\sim 80 \%) \text {. FMT form their min. }(\sim \%) \text {, while LST reach their max. }(\sim 96 \%) \text {. Dinocyst } \\
\text { concentration is } \sim 1730 \text { cysts/g. }\end{array}$ & 2240 \\
\hline
\end{tabular}




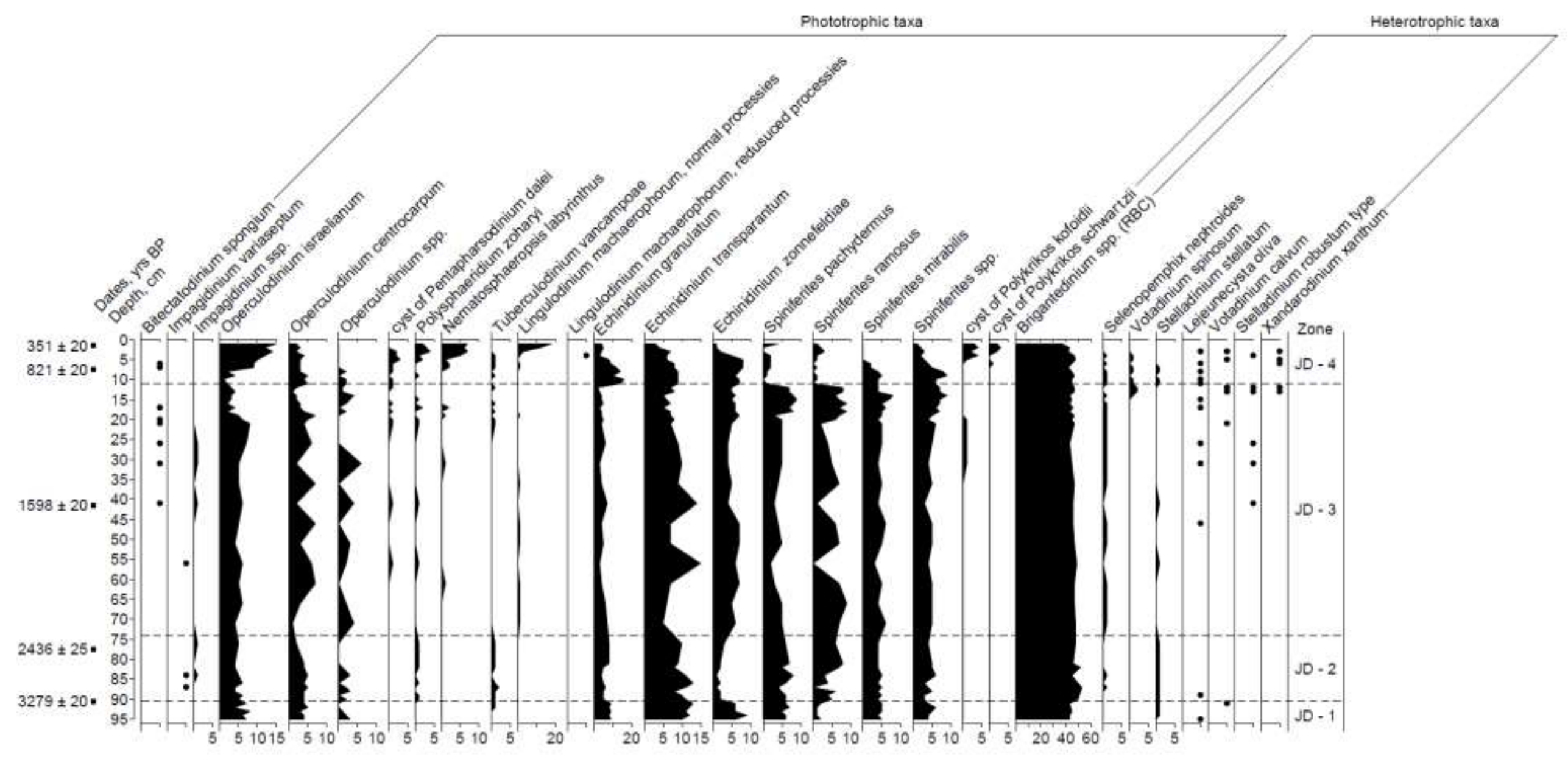

Fig. 4.5. Dinocyst diagram for the core 1412-19 showing relative frequencies of individual taxa, main groups and cyst concentration (beginning). 


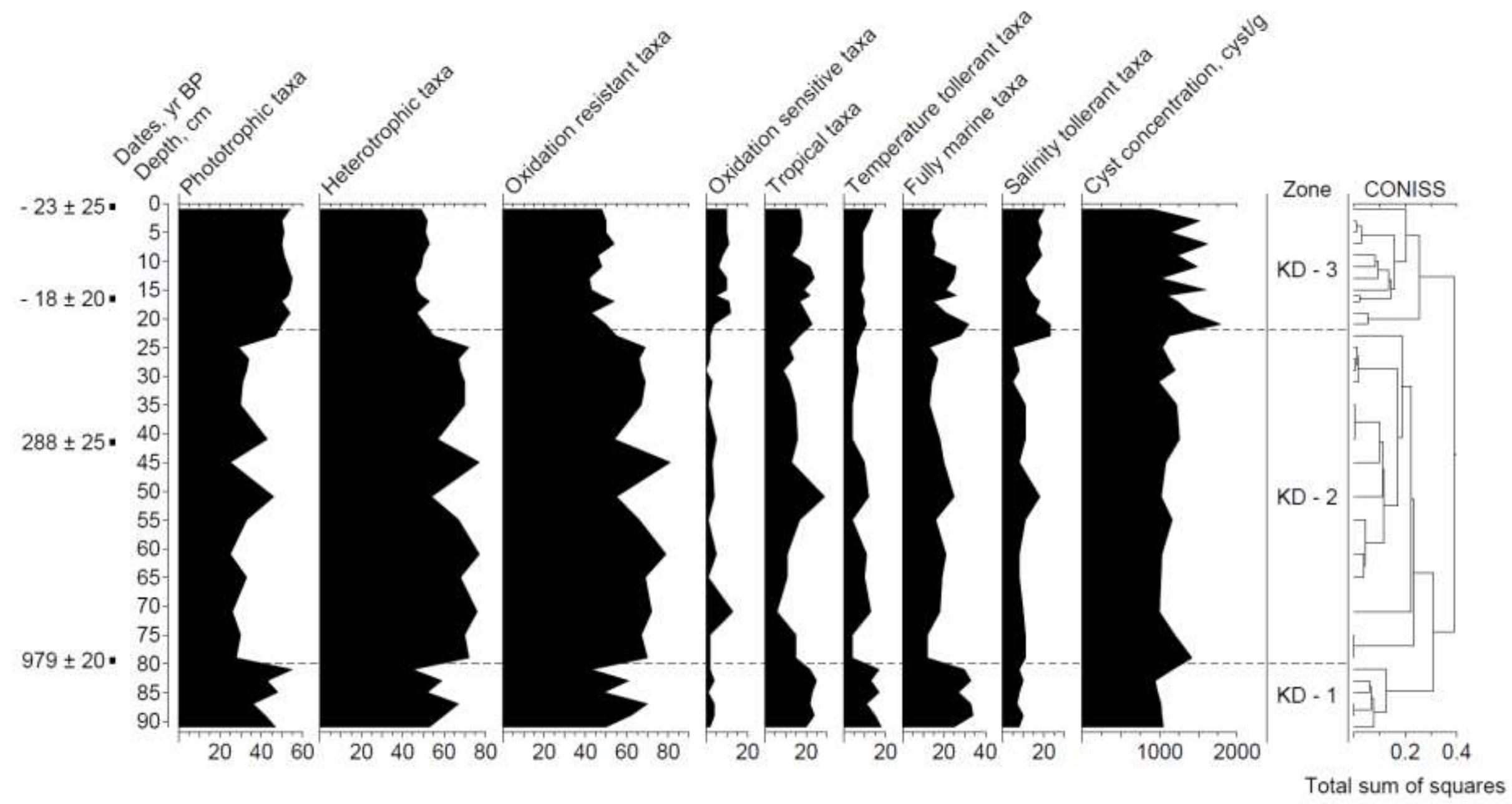

Fig. 4.5. Dinocyst diagram for the core 1412-19 showing relative frequencies of individual taxa, main groups and cyst concentration (end). 
forest at the south part of West Kalimantan' (http://wetlands.or.id/). The riparian vegetation and vegetation of peat swamp forest in the sediments of core 1412-19 were represented by 12 pollen types of woody taxa, e.g. Anacardiaceae, Dipterocarpaceae, Elaeocarpus, Engelhardia, Euphorbiaceae, Macaranga/Mallotus), although, most of these taxa could also originate from other vegetation types: pioneer growths (Macaranga/Mallotus), lowland rainforest (Anacardiaceae, Dipterocarpaceae, Elaeocarpus, Euphorbiaceae) and submontane forest (Engelhardia). Other taxa observed in the pollen association that might originate from peatland forests are Celtis, Myrsine and llex. However, all these taxa represented less than $\sim 3 \%$ of the total pollen sum and were therefore not specifically depicted in the pollen diagram. We assume not to have observed unequivocal evidence of a peatland and/or riparian forest in core 1412-19.

To date, the estuary of the river Jelai is reported to have an approximately $10 \mathrm{~m}$ wide Nypa belt only (http://wetlands.or.id/) and almost no mangrove vegetation. Nonetheless, pollen of Nypa was surprisingly absent in the most recent pollen zone of the sequence 1412-19, while observed values of other types of mangrove pollen (i.e. Avicennia, Sonneratia and Rhizophora) off S Kalimantan were higher compared to $\mathrm{E}$ Java, where mangrove contribute to the total pollen sum not more than $13-14 \%$ through the record with exception of the last zone where its contribution drops to $~ 8 \%$. The reason could be connected to the extensive destruction of the mangroves belt on Java during the recent time as it was shown by e.g. Sukardjo (1980, 1993), Whitten et al. (1996), Reeves et al. (2013) as well as in our recent work on the modern pollen in the Indian Ocean (Poliakova et al., 2014). Moreover, mangrove pollen often show the highest values within their source area (e.g. Hooghiemstra et al., 1986; Sun et al., 1999) with decreasing values with distance from shore (van der Kaars, 2001; Sun et al., 2002; Poliakova et. al., 2014).

\subsubsection{Dinocyst assemblages: preservation and translocation}

Dinocyst assemblages found in the sediment sequence 1412-19 are characterized by relatively low values of the degradation index $(\mathrm{kt})$ that does not exceed 2.9. This suggests that cyst degradation or differential preservation for this core is negligible and the palaeoenvironmental signal of the OST (round brown and spiny brown cysts especially) was not altered by oxygen-induced degradation (Versteegh and Zonneveld, 2002). Another factor that can alter the fossil dinocyst association is the relocation of the settling material (Dale, 1992; Zonneveld, 2001). Core site 1412-19 is not affected by any significant currents. For the core site 1609-30 the most relevant current that might have caused relocation of cyst material is the Karimata Strait Throughflow (KSTF) which flows along the $S$ coast of Kalimantan (Fig. 4.2). At present, KSTF has a flow speed of about $12-25 \mathrm{~cm} / \mathrm{sec}(10-22 \mathrm{~km} /$ day) with a strength being strongly depended on the monsoon strength (Wyrtky, 1957). However, taking into account the relatively high sinking rates of dinocysts of about 274 $\mathrm{m} /$ day (Zonneveld and Brummer, 2000; Zonneveld et al., 2010a) and a water depth at the core site (56.3 $\mathrm{m}$ ), we suppose that the influence of lateral drift in the study area is minor. This assumption is supported by the presence of the coastal taxa Tuberculodinium vancampoae (Marret and Zonneveld, 2003). This species is rarely observed in open marine environments and it is a typical species for coastal shallow water environments (Rochon et al., 1999; Marret and Zonneveld, 2003). This suggests that for both studied cores dinocysts associations reflect conditions of local marine environment without significant input of the material from other areas or washing away locally produced cysts. 


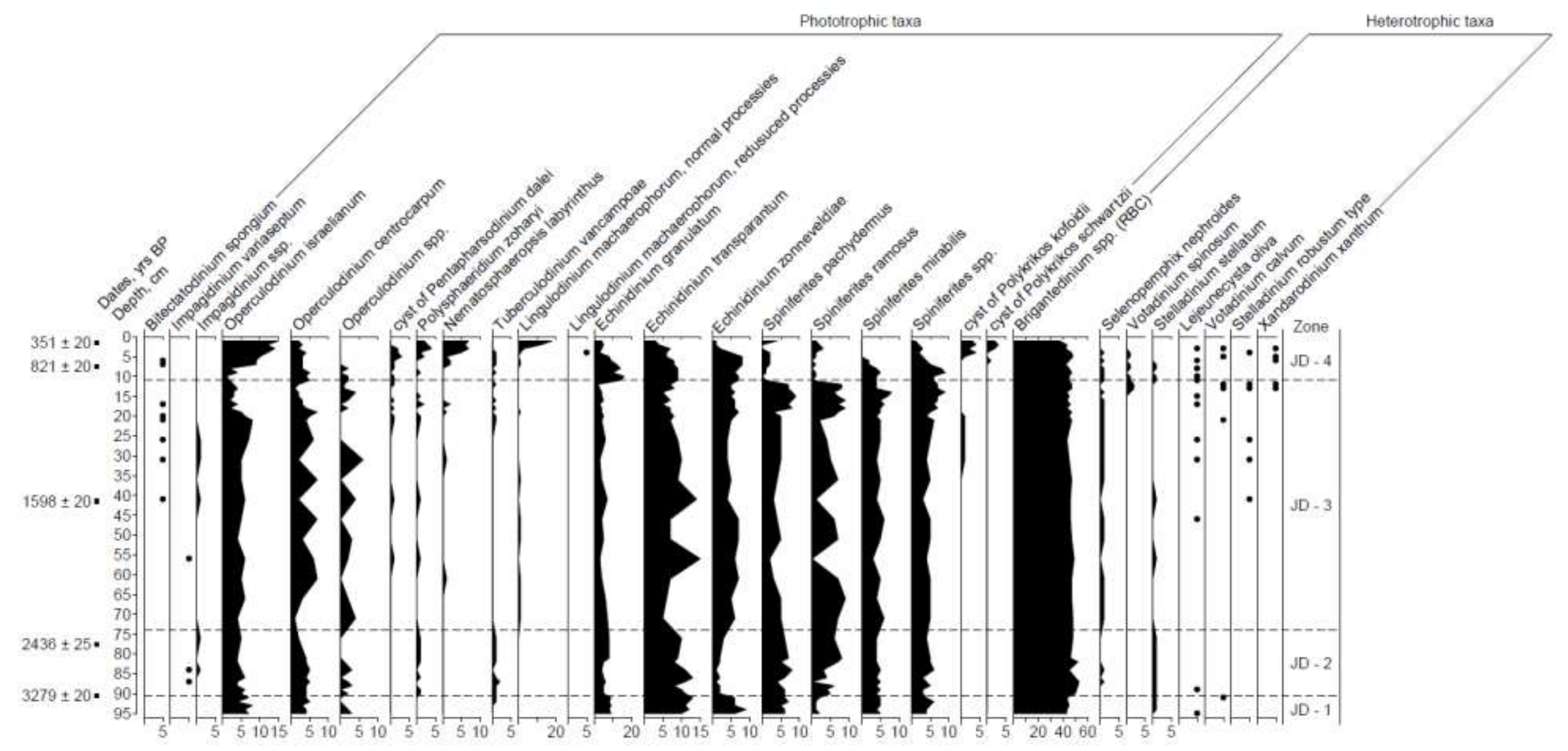

Fig. 4.6. Dinocyst diagram for the core 1609-30 showing relative frequencies of individual taxa, main groups and cyst concentration (beginning). 


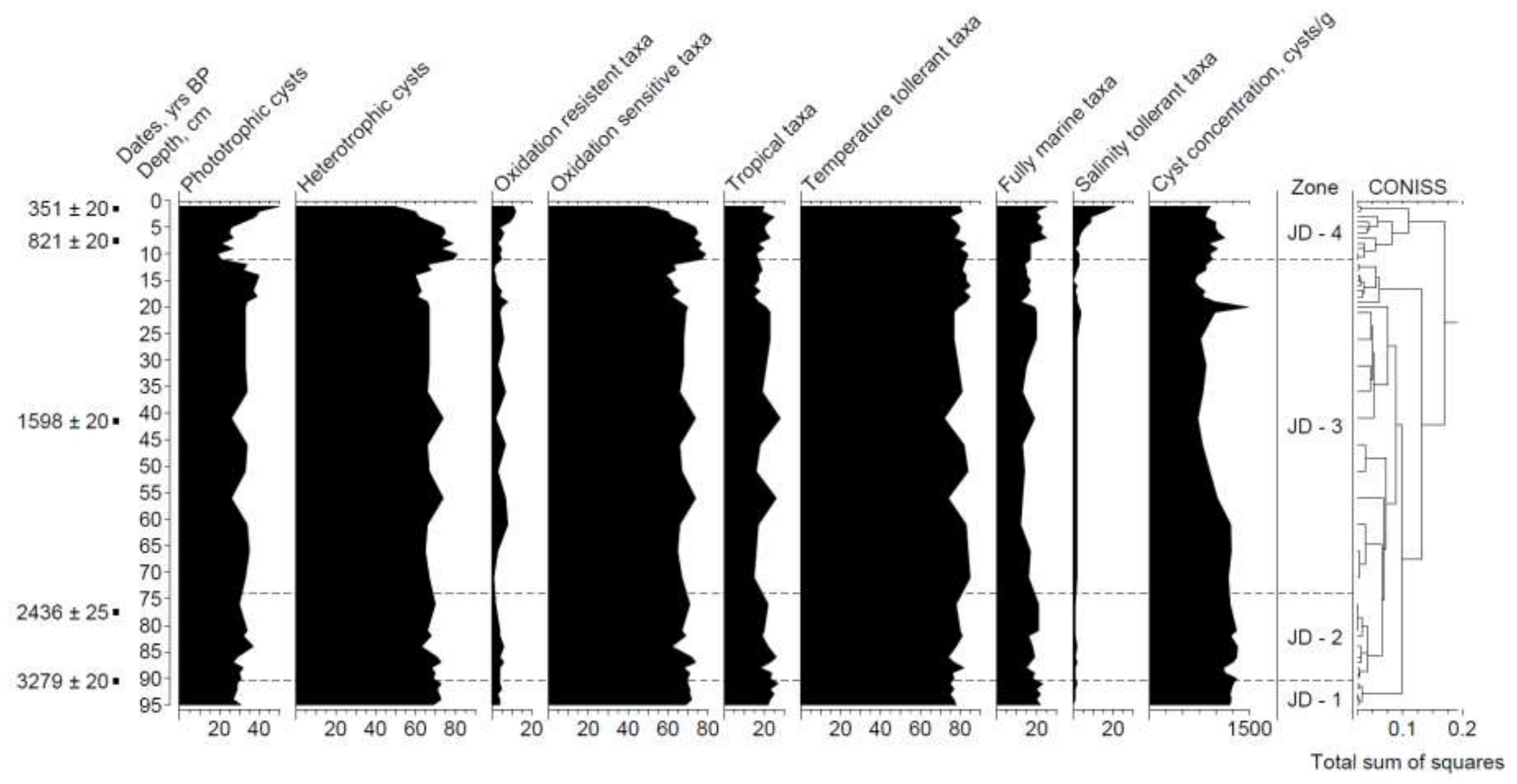

Fig. 4.6. Dinocyst diagram for the core 1609-30 showing relative frequencies of individual taxa, main groups and cyst concentration (end). 


\subsubsection{Environmental reconstructions}

\subsubsection{East Java}

Late Holocene from ca 3600 to $3215 \mathrm{cal} \mathrm{yr} \mathrm{BP} \mathrm{(pollen} \mathrm{zone} \mathrm{JP-1)} \mathrm{and} \mathrm{from} \mathrm{ca} 3600$ to $3215 \mathrm{cal}$ yr BP (dincyst zone JD-1)

Mangrove vegetation flourishes along the coast of $E$ Java off the river Solo mouth during this period. Increasing Rhizophora may be linked to a slight sea level drop between 6000 and 1000 BP after the Holocene maximum as it is proposed by Yulianto et al. (2005) for Batulicin (S Kalimantan). Alternatively, mangroves expansion can be the consequence of a somewhat higher offshore sediment accumulation, e.g. an increased input of sediments due to the enchased discharge of the river Solo which in turn, may be related to increased precipitation in the drainage area. Wet conditions are also suggested by very high relative abundances of the Cyathea and various other types of Polypodiaceae spores. Lowland rainforest with an important role of Elaeocarpus, Macaranga/Mallotus and a certain distribution of opportunistic taxa like Acalypha and Moraceae/Urticaceae at the forest border and in canopy openings was probably the dominant vegetation type developing behind mangroves at that time. Other pioneer as well as herbaceous taxa show very low values, so, despite human activity most likely was involved in the vegetation change from ca 3000-3800 yr BP in the highlands of West Java (Stuijts, 1993) and in Rava Danau (Kaars et al., 2001), in our study area anthropogenic impact had a limited or at least a constant moderate influence at the regional vegetation before $2950 \mathrm{yr}$ BP $(85-75 \mathrm{~cm})$. The most important trees in submontane areas along the river Solo at that time were Fagaceae (Lithocarpus/Castanopsis) with a more prominent role of Quercus and Myrtaceae in the canopy. Montane taxa palynologically are represented by coniferous, Podocarpus mainly.

In zone JD-1 that is fully corresponded to the pollen zone JP-1, the dinocyst associations are characterised by a high abundance of TT and/or FMT (e.g. Bitectatodinium spongium, Spiniferites pachydermis, Spiniferites mirabilis) that may point to stable environmental conditions with no abrupt events and high SST and SSS.

Late Holocene from ca 3215 to 2390 cal yr BP (pollen zone JP-2) and from ca 3215 to 2275 cal yr BP (dincyst zone JD-2)

Zone JP-2 is characterised by a reduced role of Acalypha and Ficus in the lowlands as well as by the declining of Moraceae/Urticaceae that might point to a more closed canopy forest. A marked role of Engelhardia (till ca $1480 \mathrm{cal} \mathrm{yr} \mathrm{BP)} \mathrm{and} \mathrm{Myrtaceae} \mathrm{in} \mathrm{submontane} \mathrm{forest} \mathrm{suggests} \mathrm{relatively} \mathrm{stable}$ conditions in the river Solo coachmen at this time, whereas an increasing persentages of herb pollen suggests the presence of openings in the canopy. Dinocyst associations from zone JD-2, which well corresponds with the related pollen zone having approximated time difference of $115 \pm 20 \mathrm{yr}$, suggests unchanged marine environmental conditions similar to the previously described.

Late Holocene from ca 2390 to 870 cal yr BP (pollen zone JP-3) and from ca 2275 to 910 cal yr BP (dincyst zone JD-3)

Not much changes in vegetation and environmental conditions could be inferred before about ca $1590 \mathrm{cal}$ yr BP (middle part of pollen zone JP-3, Fig. 4.6), where the clear evidences of the forest 
disturbance are observed. The reduction in Elaeocarpus corresponds with an increase of Macaranga/Mallotus which suggest a change to a much more open forest canopy. This is supported by increasing abundance of herbs ( $10 \%$ to $6 \%$ in the previous zone). In submontane forest, excessive logging is likely to have taken place as an abrupt reduction of Engelhardia is observed which finds no support in natural environmental dynamic (e.g. climate fluctuation) in the study area. The reduced abundances of ferns might suggest a change to somewhat drier conditions compared to the previous period. Alternatively and more likely, it could be a result of the general reduction in the environment suitable for fern growth, i.e. additional evidence for reduction in afforested land. The constant occurrence of Arecaceae and Arenga after ca $1000 \mathrm{cal} \mathrm{yr} \mathrm{BP} \mathrm{may} \mathrm{be} \mathrm{coupled} \mathrm{with} \mathrm{cultivation} \mathrm{of} \mathrm{sugar}$ palm and coconut plantations on Java as Stuijts (1993) and Van der Kaars, van den Bergh (2004) supposed.

In the corresponding dinocyst zone JD-3, which is shifted from pollen zone JP-3 at $40 \pm 20 \mathrm{yr}$, cyst associations show increased role of the ORT and occurrence of such dynotypes as Lingulodinium machaerophorum, Nematosphaeropsis labyrinthus, cyst of Polykrikos kofoidii and Selenopemphix nephroides those suggest a change to more eutrophic conditions in the marine environment of the Java Sea compared to the previous time period.
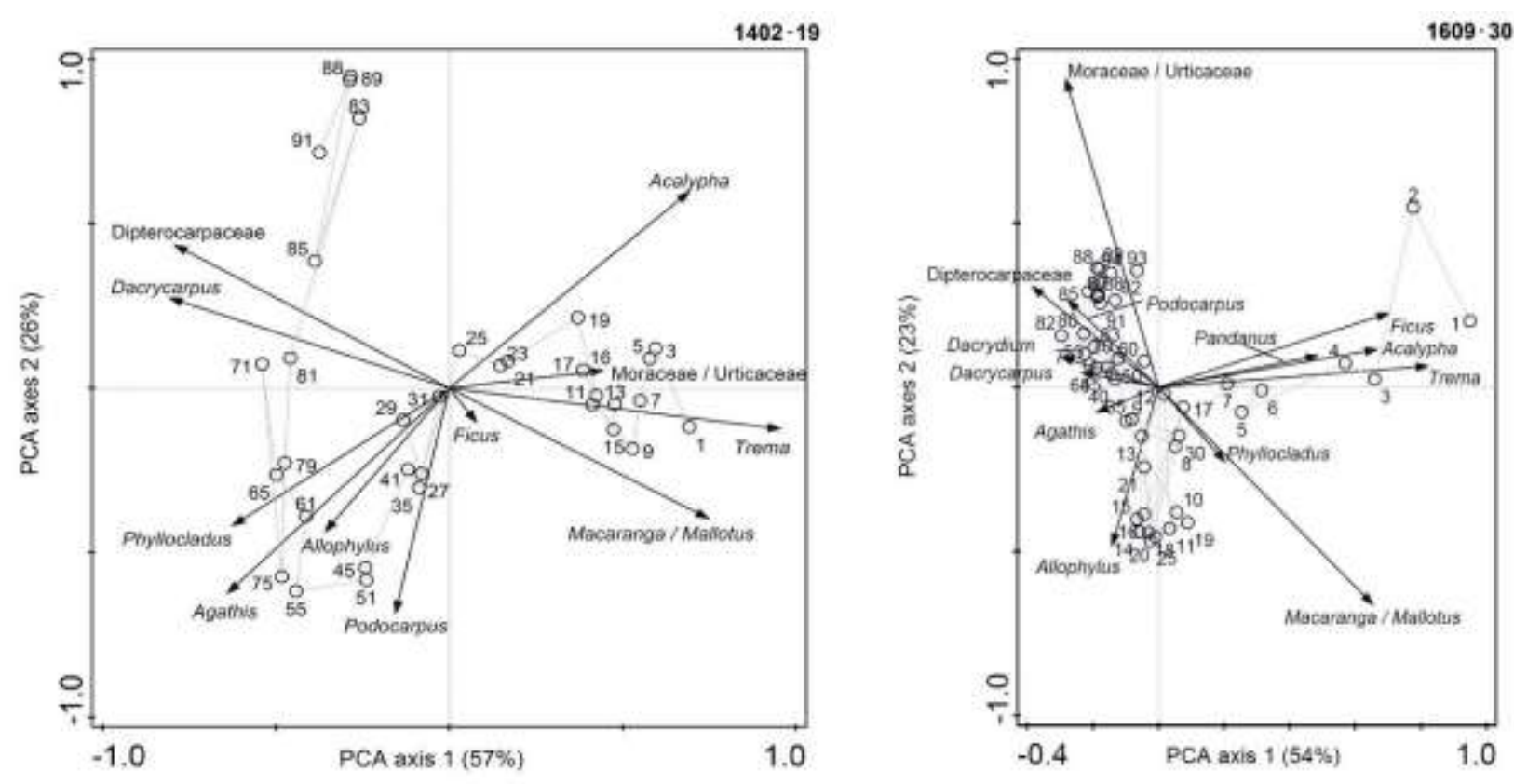

Fig. 4.7. Extraction from the ordination diagram of the principle component analysis (PCA) for pollen types from (A) core 1412-19 and (B) core 1609-30 (B). Only scores for timber trees pollen and pollen of the pioneer taxa are shown. The percentage values on the axes indicate the explained variation.

Late Holocene from ca 870 to 270 cal yr BP (pollen zone JP-4) and from ca 910 to 270 cal yr BP (dincyst zone JD-4)

Since ca $870 \mathrm{cal}$ yr BP (zone PJ-4, Fig. 4.6), the character of vegetation in E Java has changed dramatically. Pioneer taxa (e.g. Macaranga/Mallotus, Trema, Ficus, Acalypha and, from ca 500 cal yr $\mathrm{BP}$, Pandanus) dominate in the forest which is of secondary origin as the primary close-canopy forest 
has been gradually replaced by more open and less diverse communities. The same is suggested by the reduction of ferns and the strong increase of herbs (especially by Poaceae, Cyperaceae and Amaranthaceae/Chenopodiaceae). The upper three samples in pollen zone PJ-4 (430 - 270 cal yr BP) are characterised by the least abundant arboreal pollen (e.g. pollen of Elaeocarpus and Lithocarpus/Castanopsis) and evidence a strong decline in timber trees accomplished by increasing role of herbs and pioneer taxa. For the top sample (ca 270 cal yr BP) crop cultivation is evidenced (pollen of Zea mays and Oryza type are found) and, apparently, pine plantation establishment as it can be concluded from occurrence of Pinus pollen.

Main change in the taxonomical composition of dinocysts took place after ca 820 cal yr BP (middle part of zone JD-4) and is coupled with the increasing in abundances of the taxa indicating river discharge (e.g. Echinidinium transparantum and Lingulodinium machaerophorum). This shift is also indicated by the increasing values of species indicating both high phosphate (cysts of Pentapharsodinium dalei) and high nitrate concentration (Nematosphaeropsis labyrinthus, cysts of Polykrikos kofoidii and P. schwartzii) as well as by high values of the ORT. In contrast, percentages of salt water species (e.g. species of Spiniferitus) slightly decrease between ca 600 and $350 \mathrm{cal}$ yr BP. About the same time $S$. mirabilis, which is restricted to salty waters, eliminates. This could reflect an increase of the fresh water input from the river Solo that changes both the salinity budget and the trophic state of the surface waters at the core 1609-30 site. Alternatively, this change might be related to the construction of a canal from the port of Surakarta to the Java Sea that has been executed by the Dutch during this time (Dick, 2003). Thus, independently of the source of the nutrient rich waters (the river Solo or the canal), the consequences can be described as the same: logging is accompanied with increased soil wash-off and enhanced coastal water pollution that changes its trophic state and leads to development of pollution-resistant and tolerant to fresh water dinocyst types.
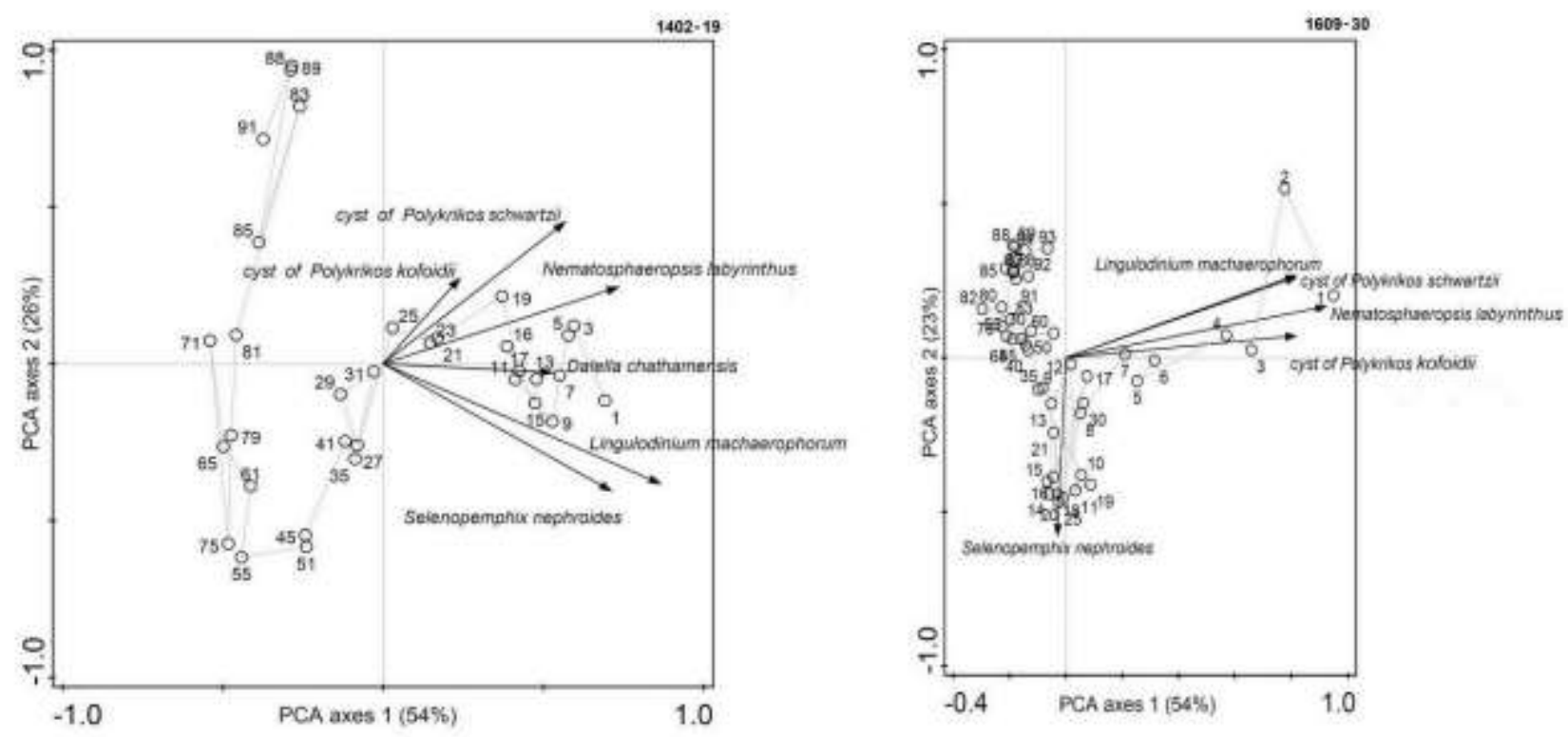

Fig. 4.8. Extractions from the ordination diagram of the principle component analysis (PCA) for dinocyst types from (A) core 1412-19 and (B) core 1609-30. Only scores for P- and N-sensitive dinoflagellate cysts are shown. The percentage values on the axes indicate the explained variation. 


\subsubsection{South Kalimantan}

Late Holocene from 1200-910 cal yr BP (pollen zone KP-1) and from ca 1200-980 cal yr BP (dinocyst zone KD-1)

Pollen deposited in this period indicates a marked role of mangrove in the coastal area off the river Jelai in S Kalimantan. The same was suggested by Yulianto et al. (2005) who studied a coastal swamp forest at Batulicin (S Kalimantan) and found that extensive mangroves have been continuously present there since the early Holocene. Behind the mangrove stands, typical for the study area fernrich mixed lowland rainforest developed that, according to the high portion and high diversity of related pollen taxa in our record, was a species-rich Dipterocarpaceae rainforest, the main type of vegetation which presently occurs in S Kalimantan (MacKinnon et al., 1997). As our age-depth model suggests, it was established at least 1200 years ago. The high values of Macaranga/Mallotus, Elaeocarpus, Moraceae/Urticaceae and Acalypha however, may indicate some opening in the forest canopy already at that time. The high frequency of Pteridophyta may point to stable wet conditions and a high level of effective precipitation during this period (e.g. Yulianto et al., 2005).

The pollen composition of submontane and montane taxa suggests that at higher elevations upstream along the Jelai River, mixed lowland forest seems to be followed by Fagaceae forest dominated by Lithocarpus/Castanopsis. Palynologically, Quercus and Myrica were less important taxa in submontane forest during this period. As for montane forest, it is reflected poorly, mostly by the coniferous taxa that have vesiculate pollen and are widely dispersed (i.e. Podocarpus, Dacrycarpus and Phyllocladus). Their pollen can easily become a subject of aeolian transport that suggests some contribution of a long distance aeolian component to the amount of montane pollen.

Dinoflagellate cyst assamblages between 1200 and 980 cal yr BP (dinocyst zone KD-1) is formed by typically warm water and FMT (e.g. Bitectatodinium spongium, Echinidinium transparantum, Operculodinium israelianum, Polysphaeridium zoharyi, Spiniferites mirabilis and S. pachydermus) that suggests rather stable tropical marine environment within the Java Sea which does not contradict to pollen-based reconstruction. Relatively high abundance of Lingulodinium machaerophorum in this zone suggests continuous and high discharge of fresh water reaching the deposition site.
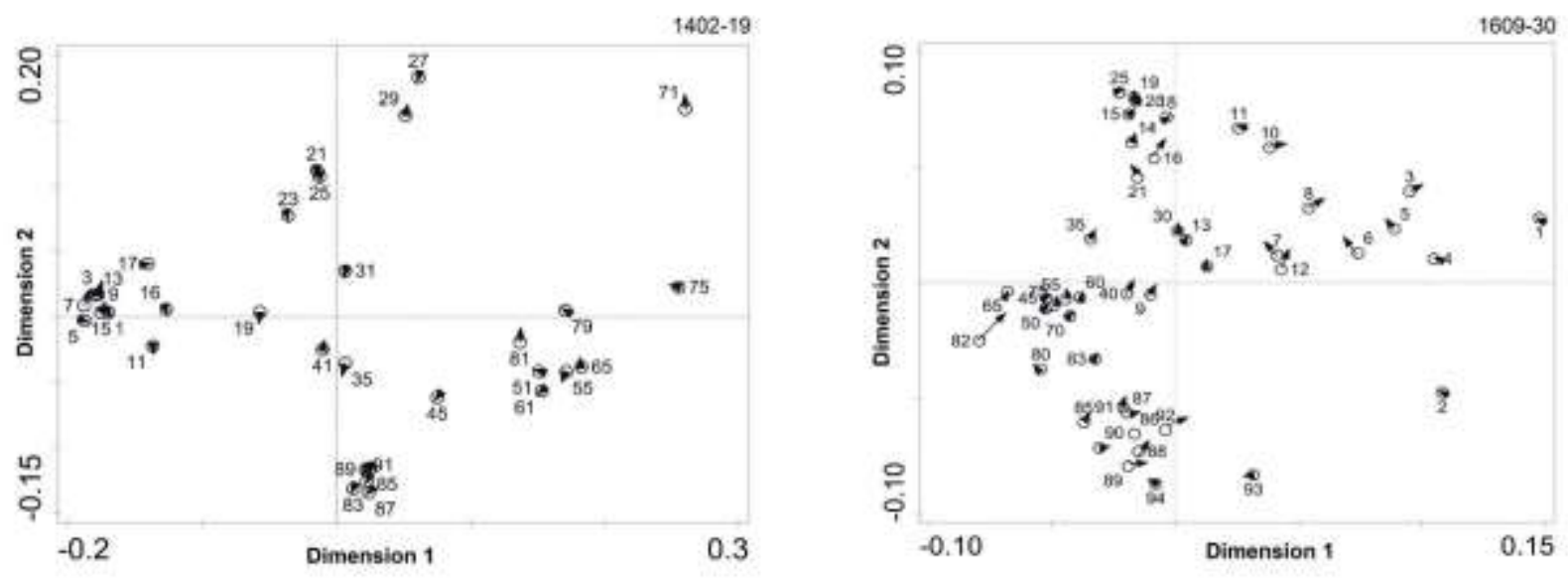

Fig. 4.9. Procrustes analysis errors in two-dimensional ordination space between pollen and dinocysts for the comparison of PCA ordinations of (A) core 1412-19 and (B) core 1609-30. The length of the 
arrows indicate the magnitude of similarity between paired sites with short arrows suggesting high similarity and long arrows suggesting low similarity.

Late Holocene from ca 910 - -20 cal yr BP (pollen zone KP-2) and from ca $980-10$ cal yr BP (dincyst zone KD-2)

During this period pollen data indicate in the lowland rainforest an increase of Macaranga/Mallotus, Acalypha, Trema and Arenga and a decrease of important timber trees such as Dipterocarpaceae and submontane Agathis and Allophyllus. This reflects an expansion of the secondary forest and pioneer taxa in the lowland rainforest that can be typically subscribed as evidence of logging (e.g. Stuijts, 1993; Yulianto et al., 2005). This assumption is supported by the observation of the increasing abundances of herbaceous taxa and the significant decrease or disappearance of pollen of such important timber trees such as Dacrycarpus (becoming absent at around $530 \mathrm{cal} \mathrm{yr}$ BP) and Phyllocladus (becoming much less frequently present after $380 \mathrm{cal}$ yr BP). Engelhardia trees may possibly increase their abundance due to the further development of peatland forest in the $S$ Kalimantan as it has been stated by Anshari et al. (2001) and Yulianto et al. (2005). Another possible reason for higher occurrence of Engelhardia at this time could be the occupation of canopy gaps by Engelhardia in the submontane forest due to logging. We do not connect these changes with climatic fluctuations as neither any additional indicators for these fluctuations in any other vegetation groups are evident. Marked reduction in mangroves (most clearly reflected by the Rhizophora record), in Lithocarpus/Castanopsis as well as in Elaeocarpus pollen that are typical for canopy openings where a lot of light is available (Whitten et al., 1996), suggests intensification of the land use and forest disturbance since ca $500 \mathrm{cal} \mathrm{yr} \mathrm{BP.} \mathrm{Changes} \mathrm{on} \mathrm{land} \mathrm{at} \mathrm{this} \mathrm{time} \mathrm{correspond} \mathrm{to} \mathrm{a}$ small alteration in the dinocyst taxonomic composition. At about ca 360-275 cal yr BP (zone KD-2, 41$45 \mathrm{~cm}$ ) a slight increase in ORT occurred that may point to somewhat less ventilation in the marine environment.

Late Holocene from ca -20 - -23 (pollen zone KP-3) and from ca $10--23$ cal yr BP (dincyst zone KD-3)

Further reduction in mangroves accompanied by a marked decline in montane taxa and in pollen of timber trees was followed by an increasing diversity and abundance of herbs, e.g. Poaceae, Cyperaceae and Amarantaceae/Chenopodiaceae especially. This suggests the reduction of closedcanopy forests along the river Jelai and high occurrence of open fields during the last decades. All this corresponds in time with the increase of human population in the area and establishing of permanent settlements. Small reduction in the tree fern Cyathea and the increasing occurrence of Lycopodium, if it is not an additional evidence of the disturbance, may be explained by some drier conditions or at least to some more pronounced difference in rainy and dry periods of the year as it is suggested by Anshari et al. (2001). Reeves et al. (2013a; 2013b) in their discussion also referred to an increasing variability of the environment and enhanced drier overall conditions of the Australasian subregion during this time. The authors connect this variability to the intensification of ENSO in the El Niño mode. First findings of pollen grains of Oryza type and Zea mays in this zone are related to the beginning of $20^{\text {th }}$ century and evidence a crop breeding. Additionally to the change in vegetation, the dinocyst composition has altered by an increase in relative abundance of HT (in particular, Selenopemphix nephroides, cyst of Polykrikos kofoidii and P. schwartzii). This may suggest changes in marine environment to more nutrient-rich conditions that could have stimulated development of 
prey organisms and, as a result, increasing in abundance of their predators (e.g. Harland et al., 2006; Dale, 2009, Zonneveld et al., 2013 and references therein). Furthermore, at this time enhanced abundance of $L$. machaerophorum occurs, which can be explained either again by the increased nutrient supply, or by the intensification of the river input (e.g. as the result of the increased precipitation) because this dinocyst type is common both in river plume areas and in nitrogen-rich waters (e.g. Zonneveld et al., 2012 and references therein). Until now there is no evidence from literature of increased precipitation in the area that could have resulted in enhanced river discharge. On the contrary, some drier conditions have been suggested during this time (e.g. Anshari et al., 2001). This stays in agreement with our conclusions done for the previous time period and most likely suggests that enhanced fresh water input at this time is not the cause of the increased presence of $L$. machaerophorum. Moreover, the sum of FMT slightly increased at this time pointing to an increase of SSS rather than to a decrease. We, therefore, assume that the increase in $L$. machaerophorum is the result of the eutrophication and connect is to the intensification of the human activity.

\subsection{General comparison of the study sites and conclusion}

Pollen, spore and dinocyst assemblages from two marine cores, retrieved off S Kalimantan and off $\mathrm{E}$ Java have been used to reconstruct the terrestrial and marine environmental changes during the last 3500 years. Pollen and dinocyst content were sufficient to produce reliable results. This first palynological study from the Java Sea inferred that environmental and vegetation changes in the region during the late Holocene were mostly related to human activity. This was clearly reflected by both studied sequences and, despite they are overlapped only minimally (see Table 4.2), general trends observed at each site are similar although occured at different time periods: forest canopy opening, decline in primary forest taxa, development of secondary vegetation with an increasing role of pioneer taxa and herbs. These shifts in both sequences are associated with an increase in the concentration of micro-charcoal (Fig. 4.5 and 4.6) suggesting that the occurrence of fires corresponds to the changes in forest canopy and can possibly be accounted as additional indicator of human activity, especially because of a traditional slash-and-burn technique.

In Java, with its long history of agriculture and human settlements, changes took place much earlier starting at ca $2950 \mathrm{cal}$ yr BP than in Kalimantan staring at ca $910 \mathrm{cal}$ yr BP and were much more intensive. A strong decline in timber trees, associated with an increase in herbs and pioneer taxa, is dated for Java (1609-30 core) back to at least 870 yr BP, while for Kalimantan (core 1412-19) such processes are evidenced only in modern times since about 1940 AD when increased population and intensification of human activity started in Kalimantan. A similar early, opening and disturbance of the forest in Java started at about $3500 \mathrm{cal} \mathrm{yr} \mathrm{BP}$ in the highlands of Central Sulawesi according to Kirleis et al. (2011).

Changes in the marine costal realm of the Java Sea evidenced from the dinocyst analysis are highly corresponded to those on land (correlation is about 0.90 with disagreement measure value of $\sim 0.004)$. They could be described as a gradual change from relatively well ventilated to more hypoxic and somewhat eutrophic conditions. Dinoflagellate associations off both the river Jelai at ca $1200-$ ca 910 cal yr BP and river Solo before 2275 yr BP are composed of warm water and fully marine taxa. Near the coast of Java, the shift in the trophic status of water took place between ca 820 and 500 cal yr BP, while near the coast of Kalimantan it occurred as late as at the beginning of the $20^{\text {th }}$ century. The occurrence of certain types of dinocysts (i.e. cyst of Polykrikos schwartzii and P. kofoidii, Lingulodinium machaerophorum, Nematosphaeropsis labyrinthus and Selenopemphix nephroides) 96 
were strongly positively correlated with the increase in pioneer taxa and negatively correlated with the increase in pollen taxa related to the primary forest (e.g. to Agathis, Allophylus, Dacrycarpus, Dacrydium, Dipterocarpaceae, Phyllocladus and Podocarpus) which are excessively logged for timber. This suggests that those dinocyst types react strongly on human induced changes in the marine environment and may potentially be used as palaeoecological indicators of anthropogenic activity.

Statistical correlation of the dinocyst and pollen data was very high. The comparison of pollen and dinocyst data and their CONISS-based clustering (Fig. 4.3-4.6) provided interesting insights on environmental changes in terrestrial and marine realm. For Java, between 3600 and $3215 \mathrm{cal}$ yr BP changes on land occurred at the same time as the changes in coastal waters of the Java Sea (beginning of pollen zone JP-2 and dinocyst zone JD-2) or were earlier (pollen zone JP-3 started about $115 \pm 20$ years before than the dinocyst zone JD-3, Fig. 4.4 and Fig. 4.6). The uppermost pollen zone (JP-4, Fig. 4.4) started at ca 870 cal yr BP which is about $40 \pm 20$ years later than the related dinocyst zone JD-4 which started at ca $910 \mathrm{cal}$ yr BP (Fig. 4.6). For Kalimantan, time differences between pollen and dinocyst zones were $70 \pm 25 \mathrm{yr}$ for KP-2 and KD-2 and $40 \pm 20 \mathrm{yr}$ for KP-3 and KD-3 (Fig. 4.3 and Fig. 4.5). To explain this time difference between pollen and dinocyst zones one needs to consider that the secondary vegetation requires some time to develop, while the dinoflagellates being unicellular organisms may respond much faster. The observed 40-70 year difference between the beginning of dinocyst and pollen zones is about the time required for establishing a pioneer community in a disturbed area and a complete re-organization of the vegetation (Whitmore, 1975; Stuijts, 1993).

\subsection{Acknowledgements}

Field material for the present research was taken during the scientific cruises of the RV "Baruna Jaya" and unknown RV in 1995-1998. The authors express their gratitude to the crew, scientific and technical assistants for their help. We thank Uta Nüsse-Hahne (University of Göttingen), Cornelia Roth and Mirijam Kiggen for the assistance in the laboratory. Dr. Mahyar Mohtadi (Center for Marine Environmental Sciences (MARUM), Bremen) is acknowledged for the help with $\mathrm{C}^{14}$ dating. Prof. Dr. Dierk Hebbeln (MARUM, Bremen) is acknowledged for reading of the manuscript. Dr. Haryadi Permana (Earth Dynamics and Geological Disaster Division Research Center for Geotechnology, Bandung, Indonesia) is acknowledged for the administrative support. All SPICE III - CAFINDO (Bremen-Göttingen) group is thanked for the discussion. Jörg Christiansen (University of Göttingen) has our regards for his computer assistance. The financial support by the German Ministry of Education and Science (Bundesministerium für Bildung und Forschung - BMBF), SPICE III - CAFINDO, Grant No. 03F0645C and No. 03F0645A are gratefully acknowledged.

\subsection{References}

Ahmad, S.M., Guichard, F., Hardjawidjaksana, K., Adisaputra, M.K., Labeyrie, L., 1995. Late Quaternary Paleoceanography of the Banda Sea. Marine Geology 122, 385-397.

Aldrian, E., Susanto, R.,D., 2003. Identification of three dominant rainfall regions within Indonesia and their relationship to sea surface temperature, International Journal of Climate, 23, 12, 14351452. doi:10.1002/joc.950

Anderson, J.A.R., Muller, J., 1975. Palynological study of a Holocene peat and a Miocene coal deposit from NW Borneo. Review of Palaeobotany and Palynology 19, 291-351. 
Andruleit, H., 2007. Status of the Java upwelling area (Indian Ocean) during the oligotrophic northern hemisphere winter monsoon season as revealed by coccolithophores. Marine Micropaleontology 25, 36-51.

Anshari, G., Kershaw, A.P., van der Kaars, S., 2001. A Late Pleistocene and Holocene pollen and charcoal record from peat swamp forest, Lake Sentarum Wildlife Reserve, West Kalimantan, Indonesia. Palaeogeography, Palaeoclimatology, Palaeoecology 171, 213-228.

Anshari, G., Kershaw, A.P., van der Kaars, S., Jacobsen, G., 2004. Environmental change and peatland forest dynamics in the Lake Sentarum area, West Kalimantan, Indonesia. Journal of Quaternary Science 19, 637-655.

Ashton, P.S., 1982. Dipterocarpaceae. Flora Malesiana series 1 (9), 237-552.

Atahan, P., Itzstein-Davey, F., Taylor, D., Dodson, J., Qind, J., Zheng, H., Brooks, A., 2008. Holoceneaged sedimentary records of environmental changes and early agriculture in the lower Yangtze, China.Quaternary Science Reviews 27, 556-570.

Backer, C.A., van den Brink, B., 1965. Flora of Java. Volumes I-III. N. V. P. Noordhoff, Groningen.

Barmawidjaja, B.M., Rohling, E.J., van der Kaars, S. A., Vergnaud, G.C., Zachariasse, W.J., 1993. Glacial conditions of the northern Molucca Sea region (Indonesia). Palaeogeography, Palaeoclimatology, Palaeoecology 101, 147-167.

Baumgart, A., Jennerjahn, T., Mohtadi, M., Hebbeln, D., 2010. Distribution and burial of organic carbon in sediments from the Indian Ocean upwelling region off Java and Sumatra, Indonesia. Deep Sea Research I 57, 458-467.

Beaufort, L., de Garidel-Thoron, T., Linsley, B., Oppo, D., Buchet, N., 2003. Biomass burning and oceanic primary production estimates in the Sulu Sea area over the last $380 \mathrm{kyr}$ and the East Asian monsoon dynamics. Marine Geology 201, 53-65.

Black, D.E., 2002. The rains may be 'a-comin'. Science 297, 528-529.

Boely, T., Linting, M., Cremoux, J.L., Petit, D., Potier, M., Nurhakim, Sujianto, S., 1991. Estimation of the abundance of pelagic fish in the central part of the Java Sea (Indonesia). Journal of Marine Fishery Research Institute 58, 107.

Burbidge, N.T., 1960. The phytogeography of the Australian region. Australian Journal of Botany 8 , 75-211.

Caratini, C., Tissot, C., 1988. Paleogeographical evolution of the Mahakam Delta in Kalimantan, Indonesia during the Quaternary and Late Pliocene. Review of Palaeobotany and Palynology 55, 217-228.

Chaturvedi, M., Datta, K., Nair, P. K. K., 1998. Pollen morphology of Oryza (Poaceae), Grana, 37 (2), 79-86, DOI: 10.1080/00173139809362647.

Chen, W., Mohtadi, M., Schefuß, E., Mollenhauer, G., 2014. Organic-geochemical proxies of sea surface temperature in surface sediments of the tropical Eastern Indian Ocean. Deep-Sea Research I 88, 17-29.

Chokkalingam, U., Kurniawan, I., Ruchiat, Y., 2005. Fire, livelihoods, and environmental change in the Middle Mahakam peatlands, East Kalimantan. Ecology and Society 10 (1), 26.

Collins, N.M., Sayer, J.A., Whitmore, T.C., 1991. The Conservation Atlas of Tropical Forests: Asia and Pacific. London, Macmillan Press.Dale, A., 2005. A perspective on the evolution of e-dialogue concerning interdisciplinary research on sustainable development in Canada. Ecology and Society $10(1), 37$. 
De Vernal, A., Rochon, A., Turon, J.-L., Matthiessen, J., 1997. Organic-walled dinoflagellate cysts: palynological tracers of sea- surface conditions in middle to high latitude marine environments. Geobios 30, 905-920.

Dick, H.W., 2003. Surabaya, City of Work: A Socioeconomic History, 1900-2000. Singapore, Singapore University Press.

Donders, T.H., Wagner, F., Visscher, H., 2005. Late-Pleistocene and Holocene subtropical vegetation dynamics recorded in perched lake deposits on Fraser Island, Queensland, Australia. Palaeogeography, Palaeoclimatology, Palaeoecology 241 (3-4), 217-239.

Donders, T. H., F. Wagner-Cremer, Visscher, H., 2008. Integration of proxy data and model scenarios for the midHolocene onset of modern ENSO variability, Quaternary Science Review 27, 571-579, doi:10.1016/j.quascirev.2007.11.010.

Dubois, N., Oppo, D.W., Galy, V., Mohtadi, M., van der Kaars, S., Tierney, J., Rosenthal, Y., Eglinton, T., Lückge, A., Linsley, B., 2014. Indonesian vegetation response to changes in rainfall seasonality over the past 25,000 years. Nature Geoscience 7, 513-517, doi:10.1038/ngeo2182.

Dupont, L.M., Schneider, R., Schmüser, A., Jahns, S., 1999. Marine-terrestrial interaction of climate changes in West Equatorial Africa of the last 190,000 years. Paleoecology of Africa 26, 61-84.

Durand, J.R., Petit, D., 1995. The Java Sea environment. in: BIODYNEX: Biology, Dynamics, Exploitation of the small pelagic fishes in the Java Sea. Potier M and Nurhakim S (eds.), Java Sea Pelagic Fishery Assessment Project 32, 65-71.

Ecosystem Area of Muller-Schwaner. Available at: http://heartofborneo.or.id/en/publication-media

Emery, K.O., Uchupi, E., Sunderland, J., Uktolseja, H.L., Young, E.M., 1972. Geologlcal structure and some water characteristics of the Java Sea and adjacent continental shell. United Nations ECAFE, CCOP Technical Bulletin 6, 197-223.

Faegri, K., Iversen, J., 1975. Textbook of Pollen Analysis, 4th Ed. Chichester, J. Wiley \& Sons Ltd.

Fang, G., Wang, Y., Wei, Z., Fang, Y., Qiao, F., Hu, X., 2009. Interocean circulation and heat and freshwater budgets of the South China Sea based on a numerical model. Dynamics of Atmospheres and Oceans 47, 55-72.

Fensome, R.A., Taylor, F.J.R., Norris, G., Sarjeant, W.A.S., Wharton, D.I., Williams, G.L., 1993. A classification of fossil and living dinoflagellates. Micropaleontology Press Special Paper. 7, 351.

Fensome, R.A., Williams, G.L., 2004. The Lentin and Williams index of fossil dinoflagellates. AASP Foundation Contributions Series 42.

Finsinger, W., Tinner, W., 2005. Minimum count sums for charcoal concentration estimates in pollen slides: accuracy and potential errors. The Holocene 15 (2), 293-297.

Fujiki, T., Zhou, Z., Yasuda, Ya., 2005. The pollen Flora of Yunnan, China. New Delhi, Lustre Press/Roli Books.

Genia, A.N., Nugroho, A.S., Olugbenda, J.O., 2007. Introduction to Java See. Oceanography. Stavanger, University of Stavanger.

Grimm, E.C., 1987. CONISS: A FORTRAN 77 program for stratigraphically constrained cluster analysis by method of incrimination sum of squares. Computers and Geosciences 13 (1), 13-35.Grimm, E.C., 1990. TILIA and TILIA.GRAPH: PC spreadsheet and graphics software for pollen data . INQUA Working Group on Data Handling Methods, Newsletter 4, Surrey: INQUA, pp. 5-7.

Grindrod, J., Moss, P.T., van der Kaars, S., 2002. Late Quaternary mangrove pollen records from the continental shelf and deep ocean cores in the north Australian region. In: Kershaw, A.P., David, B., Tapper, T., Penny, D., Brown, J. (Eds.). Bridging Wallace's Lines - the Environmental and Cultural History and Dynamics of the SE-Asian-Australian Region. Advances in Geoecology 34, 119-148. 
Harland, R., Nordberg, K., Filipsson, H.L., 2006. Dinoflagellate cysts and hydrographical change in Gullmar Fjord, west coast of Sweden. Science of the Total Environment 355, 204-231.

Hessler, I., Young, M., Holzwarth, U., Mohtadi, M., Lückge, A., Behling, H., 2013. Imprint of eastern Indian Ocean surface oceanography on modern organic-walled dinoflagellate cyst assemblages. Marine Micropaleontology 101, 89-105.

Hill, M.O., Gauch, H.G.Jr., 1980. Detrended correspondence analysis: An improved ordination technique. Vegetatio 42, 47-58.

Hooghiemstra, H., Agwu, C.O.C., Beug, H.-J., 1986. Pollen and spore distribution in recent marine sediments: a record of NW-African seasonal wind patterns and vegetation belts. Meteorologische Forschungsergebnisse 40, 87-135.

Kawamura, H., 2004. Dinoflagellate cyst distribution along a shelf to slope transect of an oligotrophic tropical sea (Sunda Shelf, South China Sea). Phycological Research 52, 355-375.

Kirleis,W., Pillar, V.D., Behling, H., 2011. Human-environment interactions in mountain rainforests: palaeo-botanical evidence from Central Sulawesi, Indonesia. Vegetation History and Archaeobotany 20, 165-179.

Kodela, P.G., 2006. Pollen morphology of some rainforest taxa occurring in Illawarra region of New South Weles, Australia. Telopea 11 (3), 346-389.

Kuhnert, H., Kuhlmann, H., Mohtadi, M., Meggers, H., Baumann, K-H., Pätzold, J., 2014. Holocene tropical Western Indian Ocean sea surface temperatures in covariation with climatic changes in the Indonesian region. Paleoceanography 29, doi:10.1002/2013PA002555.

MacKinnon, K., Hatta, G., Halim, H., Mangalik, A., 1997. The Ecology of Kalimantan. The Ecology of Indonesia Series. Singapore, Peripus Editions.

Maloney, B.K., 1990. Grass pollen and the origins of rice agriculture in north Sumatra. Modern Quaternary Research in Southeast Asia 11, 135-160.

Mao, L., Batten, D., Fujiki, T., Li, Z., Dai, L., Weng, Ch., 2012. Key to mangrove pollen and spores of southern China: an aid to palynological interpretation of Quaternary Deposits in the Southern China Sea. Reviews of Palaeobotany and Palynology 176-177, 41-67.

Marret, F., Scourse, J., Versteegh, G., Jansen, J.H.F., Schneider, R., 2001. Integrated marine and terrestrial evidence for abrupt Congo River palaeodischarge fluctuations during the last deglaciation. Journal of Quaternary Science 16, 761-766.

Marret, F., Zonneveld, K.A.F., 2003. Atlas of modern organic-walled dinoflagellate cyst distribution. Review of Palaeobotany and Palynology 125, 1-200.

Matsuoka, K., Kawami, H, Nagai, S, Iwataki, M and Takayama, H., 2009. Re-examination of cyst-motile relationships of Polykrikos kofoidii Chatton and Polykrikos schwartzii Butschli (Gymnodiniales, Dinophyceae). Review of Palaeobotany and Palynology 154 (1-4), 79-90.

Mertens, K.N., Verhoeven, K., Verleye, T., Louwye, S., Amorim, A., Ribeiro, S., Deaf, A.S., Hardubg, I.C., De Schepper, S., González, C., Kodrans-Nsiah, M., de Vernal, A., Henry, M., Radi, T., Dybkjaer, K., Poulsen, N.E., Feist-Burkhardt, S., Chitolie, J., Heilmann-Clausen, C., Londeix, L., Turon, J.-L., Marret, F., Matthiessen, J., McCarthy, F.M.G., Prasad, V., Pospelova, V., Kyffin Hughes, J.E., Riding, J.B., Rochon, A., Sangiorgi, F., Welters, N., Sinclair, N., Thun, C., Soliman, A., Van Nieuwenhove, N., Vink, A., Youn, M., 2009. Determining the absolute abundance of dinoflagellate cysts in recent marine sediments: the Lycopodium marker-grain method put to the test. Review of Palaeobotany and Palynology 157 (3-4), 238-252. DOI 10.1016/j.revpalbo.2009.05.004.

Mohtadi, M., Steinke, S., Lückge, A., Groeneveld, J., Hathorne, E.C., 2010. Glacial to Holocene surface hydrography of the tropical eastern Indian Ocean. Earth and Planetary Science Letters 292, 89-97. 
Mohtadi, M., Oppo, D.W., Lückge, A., De Pol-Holz, R., Steinke, S., Groeneveld, J., Hemme, N., Hebbeln, D., 2011. Reconstructing the thermal structure of the upper ocean: insights from planktic foraminifera shell chemistry and alkenones in modern sediments of the tropical eastern Indian Ocean. Paleoceanography 26, PA3219, doi:10.1029/2011PA002132.

Moore, P.D., Webb, J.A., 1978. An illustrated guide to pollen analysis. London, Hodder and Stoughton.

Morley, R. J., 1981. Development and Vegetation Dynamics of a Lowland Ombogenous Peat Swamp in Kalimantan Tengah, Indonesia. Journal of Biogeography 8, 383-404.

Niedermeyer, E.M., Sessions, A.L., Feakins, S.J., Mohtadi, M., 2014. Hydroclimate of the western Indo-Pacific Warm Pool during the past 24,000 years. Proceedings of the National Academy of Science 111, 9402-9406, doi:10.1073/pnas.1323585111.

Poliakova, A., Rixen, T., Jennerjahn, T., Behling, H., 2014. Annual High Resolution Pollen and Spore Sedimentation Record off SW Java in the Indian Ocean. Marine Micropalaeontology 111, 90-99.

Pospelova, V., Chmura, G.L., Boothman, W.S., Latimer, J.S., 2002. Dinoflagellate cyst records and human disturbance in two neighboring esturaries, New Bedford Harbor and Apponagansett Bay, Massachussetts (USA). The Science of the Total Environment 298, 81-102.

Pospelova, V., Pedersen, T.F. de Vernal, A., 2006. Dinoflagellate cysts as indicators of climatic and oceanographic changes during the past $40 \mathrm{kyr}$ in the Santa Barbara Basin, southern California. Paleoceanography 21, 1-16.

Potier, M., Boely, T., Nurhakim, S., Atmaja, S.B., 1989. Study on the big purse seiners lishery in the Java Sea. Environment of the Java Sea. Journal of Marine Fishery Research Institute 51, 79-100.

Reeves, J.M., Barrows, T.T., Cohen, T., J., Kiem, A., S., Bostock, H.,C., Fitzsimmons, K.E., Jansen, J.D., Kemph, J., Krause, C., Petherick, L., Phipps,S. J., OZ-INTIMATE Members, 2013a. Climate variability over the last 35,000 years recorded in marine and terrestrial archives in the Australian region: an OZ-INTIMATE compilation. Quaternary Science Reviews 74, 21-34.

Reeves, J.M., Bostock, H.C., Ayliffe, L.K., Barrows, T.T., De Deckker, P., Devriendt, L.S., Dunbar, G.B., Drysdale, R.N., Fitzsimmons, K.E., Gagan, M.K., Griffiths, M.L., Haberle, S.G., Jansen, J.D., Krause, C., Lewis, S., McGregor, H.V., Mooney, S.D., Moss, P., Nanson, G.C., Purcell, A., van der Kaars, S., 2013b. Palaeoenvironmental change in tropical Australasia over the last 30,000 years-A synthesis by the OZ-INTIMATE group Palaeoenvironmental change in tropical Australasia over the last 30,000 years-A synthesis by the OZ-INTIMATE group. Quaternary Science Reviews 74, 21-34.

Romero, O.E., Rixen, T., Herunad,i B., 2009. Effects of hydrographic and climatic forcing on diatom production and export in the tropical southeastern Indian Ocean. Marine Ecology. Progress Series 384, 69-82.

Ropelewski, C.F., Halpert, M.S., 1987. Global and regional scale precipitation patterns associated with El Niňo/Southern Oscillation. Monthly Weather Reviews 115, 1606-1626.

Sangiorgi, F., Capotondi, L., Brinkhuis, H., 2002. A centennial scale organic-walled dinoflagellate cyst record of the last deglaciation in the South Adriatic Sea (Central Mediterranean). Palaeogeography Palaeoclimatology Palaeoecology 186, 199-216.

Schlitzer, R., 2014. Ocean Data View. Available at: http://odv.awi.de.

Schott, F., McCreary, J.P., 2001. The monsoon circulation of the Indian Ocean. Progress in Oceanography 51, 1-123.

Semah, A.-M., Semah, F., Moudrikah, R., Frohlich, F., Djubiantono, T., 2004. A Late Pleistocene and Holocene sedimentary record in Central Java and its palaeoclimatic significance. Mod. Quaternary Res. SE Asia 18: 63-88. 
Semah, A.-M., 1982. A Preliminary Report on a Sangiran Pollen Diagram. Modern Quaternary Research in Southeast Asia 7, 165-170.

Semah, A.-M., 1984. Palynology and Javanese Pithecanthropus Palaeoenvironment. In: G.H.R. Von Koenigswald Memorial Symposium, Bad Homburg, 69. Cour. Forsch. Inst, Senckenberg, Frankfurt, pp. 237-243.

Shin, H.H., Mizushima, K., Oh, S.J., Park, J.S., Noh, I.H., Iwataki, M., Matsuoka, K., Yoon, Y.H., 2010. Reconstruction of historical nutrient levels in Korean and Japanese coastal areas based on dinoflagellate cyst assemblages. Marine Pollution Bulletin 60, 1243-1258.

Šmilauer, P., Lepš, J., 2014. Multivariate Analysis of Ecological Data using Canoco 5. Cambridge, Cambridge University Press.

Southon, J., Kashgarian, M., Fontugne, M., Metivier, B., Yim, W.W.S., 2002. Marine reservoir corrections for the Indian Ocean and Southeast Asia. Radiocarbon 44(1), 167 - 80.

Spooner, M.I., Barrows, T.T., De Deckker, P., Paterne, M., 2005. Palaeoceanography of the Banda Sea, and and Late Pleistocene initiation of the Northwest Monsoon. Global and Planetary Change 49 (1 $-2), 28-46$.

Stevenson, J., 1998. Late Quaternary Environmental Change and the Impact of Melanesian Colonisation in New Caledonia. Unpublished PhD Thesis. University of New South Wales, Kensington.

Stibig, H.-J., Beuchle, R., Janvier, P., 2002. Forest cover map of insular Southeast Asia at 1:5 500 000, Publications of the European Communities. Luxembourg: European Commission.

Stockmarr, J., 1971. Tablets with spores used in absolute pollen analysis. Pollen et Spores 13, 615621.

Stuijts, I., 1984. Palynological study of Situ Bayongbong, West Java. Modern Quaternary Research in South-East Asia 8, 17-27.

Stuijts, I., 1993. Late Pleistocene and Holocene vegetation of West Java, Indonesia. Modern Quaternary Research in South-East Asia 12, 1- 173.

Stuijts, I., Newsome, J.C., Flenley, J.R., 1988. Evidence for Late Quaternary vegetational change in the Sumatran and Javan highlands. Review of Palaeobotany and Palynology 55, 207-216.

Stuiver, M., Polach, H., 1977. Reporting of 14C data. Radiocarbon 19, 355-363.

Stuiver, M., Reimer, P.J., 1993. Extended 14C data base and revised CALIB $3.014 \mathrm{C}$ age calibration programme. Radiocarbon 35 (1), 215-31.

Sukardjo, S., 1980. The Mangrove Ecosystem in the Northern Coast of WestJava. In E. C. F. Bird and A. Soegiarto (Eds.) Proc. of the Jakarta Workshop on Coastal Resources Management. Tokyo, The United Nations University.

Sukardjo, S., 1993. The Present Status of the Mangrove Forests in the Northern Coast of West Java with Special Reference to the Recent Utilization. Southeast Asian Studies 31 (2), 41-157. http://hdl.handle.net/2433/56494.

Sun, X., Li, X., 1999. A pollen record of the last $37 \mathrm{ka}$ in deep sea core 17940 from the northern slope of the South China Sea. Marine Geology 156, 227-244.

Sun, X.-J., Li, X., Luo, Yu.-L., 2002. Vegetation and climate on the Sunda Shelf of the South China Sea during the last glaciation - pollen results fromstation 17962. Acta Bot. Sin. 44 (6), 746-752.

Suryantini, I.A, Kuncoro, I.A., Saputri, D., Helfinalis, F., 2011. Marine Sediment Characteristics at Karimun Java Sea Based on Stratigraphic Profile Analysis, Total Suspended Solid (TSS) and Grain Size Analysis (Granulometry). Jurnal IImu dan Teknologi Kelautan Tropis 3 (1), 26-51.

Susanto, R.D., Moore, T., Marra, J., 2006. An ocean color variability in the Indonesian Seas during the SeaWifs Era, Geochemistry, Geophysics, Geosystems 7, 1-16. doi:10.1029/2005GC001009.

102 
The Giovanni Ocean Colour Radiometry Portal. Available at: http://gdata1.sci.gsfc.nasa.gov/daacbin/G3/gui.cgi?instance_-id=ocean_-8day/

Tweddle, J.C., Edwards, K.J., Fieller, N.R.J., 2005. Multivariate statistical and other approaches for the separation of cereal from wild Poaceae pollen using a large Holocene dataset. Vegetation History and Archaeobotany 14, 15-30.

Van der Kaars, S., 1991. Palynology of eastern Indonesian piston cores: a Late Quaternary vegetational and climatic record for Australasia. Palaeogeography, Palaeoclimatology, Palaeoecology 85, 239-302.

Van der Kaars, S., 2001. Pollen distribution in marine sediments from the south-eastern Indonesian waters. Palaeogeography, Palaeoclimatology, Palaeoecology 171, 341-361.

Van der Kaars, S., Bassinot, F., De Deckker, P., Guichard, F., 2010. Changes in monsoon and ocean circulation and the vegetation cover of southwest Sumatra through the last 83,000 years: the record form marine core BAR94-42. Palaeogeography, Palaeoclimatology, Palaeoecology 296, 52 78.

Van der Kaars, S., Dam, M.A.C., 1995. A 135,000-year record of vegetational and climatic change from the Bandung area, West-Java, Indonesia. Palaeogeography, Palaeoclimatology, Palaeoecology 117, 55-72.

Van der Kaars, S., Dam, R., 1997. Vegetation and climate change in West Java, Indonesia during the last 135,000 years. Quaternary International 37, 67-71.

Van der Kaars, S., van den Bergh, G.D., 2004. Anthropogenic changes in the landscapes of West Java (Indonesia) during historic times, inferred from a sediment and pollen record from Teluk Banten. Journal of Quaternary Science 19 (3), 229-239.

Van der Kaars, S., Wang, X., Kershaw, A.P., Guichard, F., Setiabudi, D.A., 2000. Late Quaternary palaeoecological record from the Banda Sea, Indonesia: patterns of vegetation, climate and biomass burning in Indonesia and northern Australia. Palaeogeography, Palaeoclimatology, Palaeoecology 155, 135-153.

Van der Kaars, S., Wang, X., Kershaw, A.P., Guichard, F., Setiabudi, D.A., 2000. A Late Quaternary palaeoecological record from the Banda Sea, Indonesia: Patterns of vegetation, climate and biomass burning in Indonesia and northern Australia. Palaeogeography, Palaeoclimatology, Palaeoecology 155, 135-153.

Van der Kaars, S., Wang, X., Kershaw, A.P., Guichard, F., Setiabudi, D.A ., 2000. A Late Quaternary palaeoecological record fromthe Banda Sea, Indonesia: patterns of vegetation, climate and biomass burning in Indonesia and northern Australia. Palaeogeography, Palaeoclimatology, Palaeoecology 155, 135-153.

Van der Kaars, S., Williams, M.A.J., Bassinot, F., Guichard, F., Moreno, E., Dewilde, F., Cook, E.K., 2012. The influence of the 73 ka Toba super-eruption on the ecosystems of northern Sumatra as recorded in marine core BAR94-25. Quaternary International 258, 45-53.

Van der Meer, M., Sangiorgi, F., Baas, M., Brinkhuis, H., Damste, J.S.S., Schouten, S., 2008. Molecular isotopic and dinoflagellate evidence for Late Holocene freshening of the Black Sea. Earth and Planetary Scientific Letters 267 (3-4), 426-434.

Van Steenis, C.G.G.J., 1984. Floristic altitudinal zones in Malaysia. Botanical Journal of the Linnean Society $89,289-292$.

Van Waveren, I.M., 1989. Palynofacies analysis of surface sediments from the northeastern Banda Sea (Indonesia). Netherlands Journal of Sea Research 24 (4), 501-509.

Veen, P.C.H., 1953. Preliminary charts the mean salinity the Indonesian archipelago and adjacent waters. Org. Sei. Res. Indonesia 17, 1-46. 
Verleye, T., Louwye, S., 2010. Recent geographical distribution of organic-walled dinoflagellate cysts in the southeast Pacific $\left(25-53^{\circ} \mathrm{S}\right)$ and their relation to the prevailing hydrographical conditions. Palaeogeography, Palaeoclimatology, Palaeoecology 298 (3-4), 319-340.

Versteegh, G.J.M., Zonneveld, K.A.F., 2002. Use of selective degradation to separate preservation from productivity. Geology 30 (7), 615-618.

Visser, K., Thunell, R., Goni, M.A., 2004. Glacial-interglacial organic carbon record fromthe Makassar Strait, Indonesia: implications for regional changes in continental vegetation. Quaternary Science Reviews 23, 17-27.

Wang, F., Chien, N., Yulong, Z., Huiqui, Y., 1995. Pollen flora of China. Second edition. Beijing, Institute of botany, Academia Sinica.

Wang, P., Clemens, S., Beaufort, L., Braconnot, P., Ganssen, G., Jian, Z., Kershaw, P., Sarnthein, M., 2005. Evolution and variability of the Asian monsoon system: State of the art and outstanding issues. Quaternary Science Review 24 (5-6), 595-629.

Wang, P., Prell, W., Blum, P., 2000. Proceedings of the ocean drilling program. Texas A\&M University, college station TX 778445-9547. Initial Reports 184, 1-48.

Wang, X., van der Kaars, S., Kershaw, A.P., Bird, M., Jansen, F., 1999. A record of vegetation and climate through the last three glacial cycles from Lombok Ridge core G6-4, eastern Indian Ocean, Indonesia. Palaeogeography, Palaeoclimatology, Palaeoecology 147, 241-256.

Weng, Ch., Shimeld, P., Bowman, D., van der Kaars, S., Sniderman, K., 2007. The Australasian Pollen and Spore Atlas, Australian National University, Canberra. Available at: http://apsa.anu.edu.au/.

Weninger, B., Danzeglocke, U., Jöris, O., 2007. Glacial radiocarbon age conversion. Cologne radiocarbon calibration and palaeoclimate research package <CALPAL> Köln: Universität zu Köln, Institut für Ur- und Frühgeschichte. User manual is available from: www.calpal.de.

Whitmore, T.C., 1984. Tropical rain forests of the Far East. (2nd ed.). Oxford University Press, Oxford. Whitmore, T.C., 1990. An Introduction to Tropical Rain Forest. Clarendon Press, Oxford.

Whitten, T., Soeriaatmadja, R.E., Afiff, S.A., 1996. The Ecology of Java and Bali. Singapore, Periplus Editions.

Willard, D.A., Bernhardt, C.E., Brooks, G.R., Cronin, T.M., Edgar, T., Larson, R., 2007. Deglacial climate variability in central Florida, USA. Palaeogeography, Palaeoclimatology, Palaeoecology 251, 366 382.

Wrytki, K., 1961. Physical Oceanography of the Southeast Asian Water, Naga Report V.2. Scripps Institute of Oceanography, University of California.

Yulianto, E., Hiroyuki, T., Sri, S., Noriyuki, T., 2005. A Holocene pollen and charcoal record from a tropical lowland swamp in Rawa Danau, West Java, Indonesia. Tropics 14, 271-281.

Yulianto, E., Sukapti, W.S., Rahardjo, A.T., Noeradi. D., Siregar, D.A., Suparan. P., Hirakawa, K., 2004. Mangrove shoreline responses to Holocene environmental change, Makassar Strait, Indonesia. Review of Palaeobotany and Palynology 131 (3-4), 251-268.

Zheng, Q., Fang, G., Song, Y.T., 2006. Introduction to special section: Dynamic Processes and Circulation in Yellow Sea, East China Sea, and and South China Sea. Journal of Geophysical Research 111. C11S01, doi: 10.1029/2005JC003261.

Zonneveld, K.A.F., 1997. New species of organic walled dinoflagellate cysts from modern sediments of the Arabian Sea (Indian Ocean). Review of Palaeobotany and Palynology 97, 319-337.

Zonneveld, K.A.F., 2008. Report and preliminary results of R/V Poseidon Cruise P339, Piräus Messina, 16 June - 2 July 2006. CAPPUCCINO - Calabrian and Adriatic palaeoproductivity and climatic variability in the last two millennia. Berichte, Fachbereich Geowissenschaften, Universität Bremen 268, 1-61. 
Zonneveld, K.A.F., Brummer, G.A., 2000. (Palaeo-)ecological significance, transport and preservation of organic-walled dinoflagellate cysts in the Somali Basin, NW Arabian Sea. Deep Sea Research II (47), 2229-2256.

Zonneveld, K. A. F., Versteegh, G., Kodrans, Nsiah, M., 2008. Preservation and organic chemistry of late Cenozoic organic-walled dinoflagellate cysts; a review. Marine Micropaleontology 68 (1-2), 179-197

Zonneveld, K.A.F., Chen, L., Möbius. J., Mahmoud, M., 2009. Environmental significance of dinoflagellate cysts from the proximal part of the Po-river discharge plume (off southern Italy, Eastern Mediterranean). Journal of Sea Research 62, 189-213.

Zonneveld, K.A.F., Susek, E., Fischer, G., 2010. Seasonal Variability of the Organic-Walled Dinoflagellate Cyst Production in the Coastal Upwelling Region off Cape Blanc (Mauritania): a FiveYear Survey. Journal of Phycology 46 (1), 202-215.

Zonneveld, K.A.F., Chen, L., El-Shanawany, R., Fischer, H.W., Hoins, M., Pittaurova, D., 2012. The use of dinoflagellate cysts to separate human-induced from natural variability in the trophic state of the Po River discharge plume over the last two centuries. Marine Pollution Bulletin 64, 114-132.

Zonneveld, K.A.F., Marret, F., Versteegh, G.J.M., Bogus, K., Bonnet, S., Bouimetarhan, I., Crouch, E., de Vernal, A., Elshanawany, R., Edwards, L., Esper, O., Forke, S., Grøsfjeld, K., Henry, M., Holzwarth, U., Kielt, J.-F., Kim, S.-Y., Ladouceur, S., Ledu, D., Chen, L., Limoges, A., Londeix, L., Lu, S.-H., Mahmoud, M.S., Marino, G., Matsouka, K., Matthiessen, J., Mildenhal, D.C., Mudie, P., Neil, H.L., Pospelova, V., Qi, Y., Radi, T., Richerol, T., Rochon, A., Sangiorgi, F., Solignac, S., Turon, J.L., Verleye, T., Wang, Y., Wang, Z., Young, M., 2013. Atlas of modern dinoflagellate cyst distribution based on 2405 data points. Review of Palaeobotany and Palynology 191, 1-197.Zonneveld, K.A.F., Pospelova, V. 2015. A determination key for modern dinoflagellate cysts. Palynology. 1-23. http://dx.doi.org/10.1080/01916122.2014.990115. 


\title{
CHAPTER 5
}

\section{High-resolution multi-proxy reconstruction of environmental changes in coastal waters of the Java Sea, Indonesia, during the late Holocene}

\author{
Anastasia Poliakova ${ }^{a}$, Karin A.F. Zonneveld ${ }^{b}$, Lucia S. Herbeck ${ }^{c}$, Tim C. Jennerjahn ${ }^{c}$, Haryadi \\ Permana ${ }^{d}$, Cornelia Kwiatkowski ${ }^{b}$ and Hermann Behling ${ }^{a}$
}

(a) Albrecht-von-Haller-Institute for Plant Sciences, Department of Palynology and Climate Dynamics, Georg-August-Universität-Göttingen, Untere Karspüle 2, Göttingen, D-37073 Germany;

(b) Center for Marine Environmental Sciences (MARUM), Bremen, D-28359 Germany;

(c) Leibniz Center for Tropical Marine Ecology (ZMT), Bremen, D-28359 Germany;

(d) Earthquake and Geodynamics Research Group, Research Center for Geotechnology, Indonesian Institute of Sciences, Bandung, 40135 Indonesia

Palynology: http://dx.doi.org/10.1080/01916122.2016.1162865

ISSN: 0191-6122 (Print) 1558-9188 (Online)

Keywords: late Holocene; organic-walled dinoflagellate cysts; marine biogeochemistry; reconstruction of palaeoenvironment; SE Kalimantan; Java Sea. 


\section{Abstract}

To obtain insight into the natural variability of the coastal ecosystems off southern Kalimantan, late Holocene environmental conditions between ca. 2850 and 990 cal yr BP in the Java Sea were investigated. A 134-cm-long sediment core collected $\sim 50 \mathrm{~km}$ off the Pembuang River mouth was analysed for organic-walled dinoflagellate cysts, pollen/spores and biogeochemical parameters, e.g. organic carbon (Corg), total nitrogen $(\mathrm{N})$ and calcium carbonate $(\mathrm{CaCO})$ as well as carbon and nitrogen stable isotope composition ( $113 \mathrm{C}, \mathrm{d} 15 \mathrm{~N})$. Sediments consist of mixed terrestrial as well as marine organic matter, are characterised by low nutrient uptake and suggest generally low river discharge that is supported by very low pollen and spore concentrations ( 256 pollen grains $\mathrm{cm}^{-3}$ and 20 spores $\mathrm{cm}^{-3}$ at maximum, respectively). Foraminifera and coccolithophores dominated the plankton over cyst-producing dinoflagellates and diatoms. Dinoflagellate cyst assemblages are composed mainly of oxidation-resistant species of the genera Operculodinium and Spiniferites with a minor contribution of Impagidinium (mainly I. strialatum). The percentages of round brown and peridinioid cysts are low and decrease from the bottom of the core to the top. Palynological and biogeochemical data appear well correlated and synchronously reflect changes in the marine environment. It is reconstructed that after ca. $2480 \mathrm{cal} \mathrm{yr} \mathrm{BP}$, bottom waters became increasingly ventilated. A typical open-water dinoflagellate cyst association is gradually replaced by a more coastal association between ca. 2480 and 1530 cal yr BP that is most likely attributed to El Niňoinduced seasonal differences between dry and wet periods of the year. After $1530 \mathrm{cal}$ yr BP, a more pronounced influence of the Pembuang River is indicated by an increase in $\mathrm{d} 15 \mathrm{~N}$ and decreased $\mathrm{d} 13 \mathrm{C}$ which is supported by the occurrence of nutrient-sensitive Lingulodinium machaerophorum and Nematosphaeropsis labyrinthus. The overall results indicate short-scale local environment fluctuations attributed to abiotic factors.

\subsection{Introduction}

Over the last decades, coastal regions in the tropics have become increasingly influenced by anthropogenic activities. Since these regions are of major economic and environmental importance, it is essential to maintain their sustainability. One of the regions where anthropogenic pressure has increased strongly during the last decades is the Java Sea, Indonesia. However, apart from anthropogenic forcing, obviously also natural factors influence the coastal ecosystems in this region. For adequate planning of maintenance measurements, it is essential to have insight into the natural forcing as well. This can be achieved by studying ecosystem variability at times of relatively pristine conditions, hence prior to the major industrial/agricultural revolution. This requires detailed hightemporal-resolution information about environmental change in the last few millennia as well as the 
relations between land and ocean. Coastal sediments are well-known archives that can preserve signatures of high temporal resolution environmental change. By studying the sediments with a multi-proxy approach combining marine palynological (study of marine dinoflagellate cysts and pollen/spores) and biogeochemical techniques, information about past changes in the marine system as well as its relations with changes on the surrounding land can be obtained. Here we use this approach to gain insight into the natural variability of a coastal ecosystem of the Java Sea off southern Kalimantan.

Several palaeoenvironmental studies have been conducted in the Java Sea and in the surrounding islands since the end of the last century. Probably the first scientific paper dedicated to the marine environment of the region was published by Emery et al. (1972). These authors studied the physical water characteristics of the Java Sea and adjacent continental shelf. Detailed descriptions of the climate, marine currents, bottom sediments and biota of the Java Sea are given by Boely et al. (1991) and Durand \& Petit (1995). Since then, several studies have focused on the history of ocean current systems, sea level change, and sediment composition (e.g. Gingele et al. 2002; Hanebuth et al. 2000; Horton et al. 2007; Suryantini et al. 2011). Others focused on palaeoenvironmental changes on the surrounding land such as the reconstruction of the palaeoenvironment of Kalimantan (e.g. Anderson \& Muller 1975; Morley 1981; Caratini \& Tissot 1988; Anshari et al. 2001; Weiss 2002; Anshari et al. 2004; Griffiths et al. 2009; Dommain et al. 2014 and Poliakova et al., 2014, 2015). Until now no comprehensive high temporal resolution land-sea correlation of the region is available. For the Indonesian region, a few studies on the modern organic-walled dinoflagellate cyst associations have been published (Lirdwitayaprasit 1997, 1998; Azanza et al. 2004). Most of these studies focus on toxic algal blooms (Gonzales 1989; Wiadnyana et al. 1994; Bajarias 1995; Matsuoka et al. 1999; Mizushima et al. 2007; Reotita et al. 2008; Furio 2006, 2012 and references therein). In addition, dinoflagellate cysts diversity and spatial distribution in relation to modern local environmental conditions in the eastern Indian Ocean off SE Indonesia and N Australia were presented by Hessler et al. (2013). This work documents three environmental and oceanographic regions characterized by differences in annual sea surface temperature (SST) patterns and nitrogen supply.

To date, palaeoecological studies based on dinoflagellate cyst associations from the Indonesian region are not available. Here we present the first comprehensive study of the dinoflagellate cyst succession during the late Holocene for the time interval between 2850 and $990 \mathrm{cal} \mathrm{yr} \mathrm{BP}$. By combining these results with biogeochemical information, we establish a detailed land-sea correlation with decadal resolution of the coastal Java Sea ecosystem, off SE Kalimantan during the late Holocene and estimate the natural and human induced impact on this system.

\subsection{Study site}


The Java Sea is a large $\left(310,000 \mathrm{~km}^{2}\right)$ shallow sea (in general between $100-40 \mathrm{~m}$ water depth) on the Sunda Shelf which lies between the islands of Kalimantan (Borneo) to the north, Java to the south; Sumatra to the west and Sulawesi to the east (Figure 1). In the west, it is open to the Indian Ocean, the South China Sea by the Sunda Strait and the Karimata Strait, respectively. In the east, it has an open connection to the Flores Sea and to the Celebes Sea through the Makassar Strait (Durand \& Petit 1995; Genia et al. 2007).

The Pembuang (Seruyan) River is one of the peat draining rivers in Indonesia (see map in Couwenberg et al. 2009) and is one of the longest among the rivers of the Indonesian province of Central Kalimantan that flows into the Java Sea. It stretches over $350 \mathrm{~km}$ draining a catchment of about 200 km² (http://eyeglobe-indonesiaku.blogspot.de/2009/11/central-kalimantan.html).

At the present time, the area has a tropical monsoon climate characterized by a reversal of the wind and marine current regimes (Writky 1961; Durand \& Petit 1995) with an eight-month rainy season and four-months of a drier season. The rate of precipitation varies from 2,776 to 3,393 $\mathrm{mm}$ with about 145 rainy days per year (http://eyeglobe-indonesiaku.blogspot.de/2009/11/centralkalimantan.html). It is strongly influenced by the climate anomaly known as El Niňo Southern Oscillation (ENSO), with its two extreme faces, El Niňo and La Niňa that can respectively decrease and increase precipitation rates over the Indonesian Archipelago. These phenomena cause heavy rainfall during the NW monsoon between December and March and may cause severe droughts occurring during the SE monsoon season between June and October (e.g. Ropelewski \& Halpert 1987; Aldrian \& Susanto 2003). The summer monsoon is relatively weak compared to the winter monsoon (Liu \& Xie 1999).

The annual average sea surface temperature (SST) in the Java Sea is about $28^{\circ} \mathrm{C}$ with some small variation of $2^{\circ} \mathrm{C}$ (Wrytki 1961). Sea surface salinity (SSS) in the study area varies from relatively low values of 30.6-32.0 in the near-shore areas where the rivers of Kalimantan (e.g. Pembuang, Mendawai, Barito) discharge to about 34 in the more offshore regions.

The Java Sea water dissolved oxygen is about 4.5-4.7 $\mathrm{mg} \mathrm{l}^{-1}$ near the bottom and about $5 \mathrm{mg} \mathrm{l}^{-1}$ at the surface (Boely et al. 1991; Sadhatomo 2006). According to the World Ocean Atlas (2009), the waters off the south-eastern cost of Kalimantan are slightly less well ventilated compared to the waters in more western parts of the sea. However, this difference in the dissolved oxygen does not exceed 0.2$0.5 \mathrm{umol} \mathrm{I}^{-1}$ and is too small to form a distinct environmental gradient. Distribution of the chlorophyll$a$ has a clear pattern within the study area: off Kalimantan it is relatively low $\left(1.5 \mathrm{mg} \mathrm{m}^{-3}\right)$ while in the eastern part of the sea it is comparably high and may reach $3 \mathrm{mg} \mathrm{m}^{-3}$.

\subsection{Material and Methods}

\subsubsection{Sediment core}


Sediment material for this study (core 1612-23; S3 ${ }^{\circ} 35^{\prime} 21.84^{\prime \prime} \mathrm{E} 112^{\circ} 44^{\prime} 13.56 "$, Figure 1) was collected about $50 \mathrm{~km}$ off the Pembuang River mouth, from a water depth of $20 \mathrm{~m}$. The core is 134 $\mathrm{cm}$-long and is composed of relatively dry pale-grey silt sandy sediments, slightly brownish towards the upper part and containing many irregular fragments of shells and siliceous material that ranges in size from angular blocky pieces up to $1.5 \mathrm{~cm}$ in length to small $(1-2 \mathrm{~mm})$ sand-sized particles.

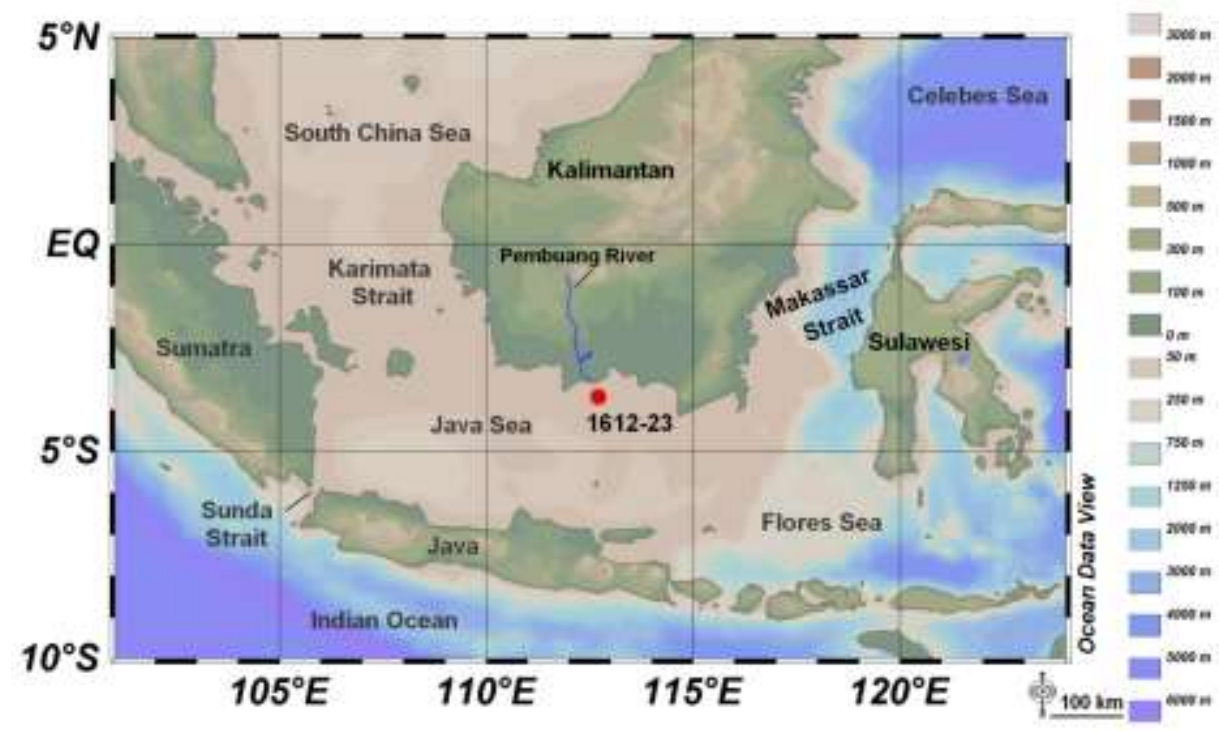

Figure 1. Study area with main water depths, land orography (delivered from the World Ocean Atlas 2009) and a position of the study site (marked with a dot). The map was created using the Ocean Data View software (Schlitzer 2014).

\subsubsection{Age control}

The age control for the investigated sediment core is based on accelerator mass spectrometry (AMS) radiocarbon dating that has been conducted at the Keck Carbon Cycle Accelerator Mass Spectrometry Facility at the University of California (Irvine, USA). Five radiocarbon dates obtained from mixed benthic foraminifera and are presented in Table 1. The results have been corrected for isotopic fractionation with $\delta^{13} \mathrm{C}_{\mathrm{org}}$ values according to the method described by Stuiver \& Polach (1977) and calibrated to calendar years with the online version of CALIB 7, marine 13 (Stuiver \& Reimer 1986, 1993; Stuiver et al. 1998, 2005; nhttp://calib.qub.ac.uk/calib) considering a reservoir age of $90 \mathrm{yr}$ (Southon et al. 2002). To create an age-depth model, a linear extrapolation approach was used.

Table 1. Radiocarbon dates obtained from the sediment core 1612-23.

\begin{tabular}{|c|c|c|c|c|c|}
\hline $\begin{array}{c}\text { Depth, } \\
\text { cm }\end{array}$ & $\begin{array}{c}\text { UCIAMS } \\
\text { lab no. }\end{array}$ & $\begin{array}{c}14 \text { C age, } \\
\text { yr BP }\end{array}$ & $\begin{array}{c} \pm \text { error, } \\
\text { yr BP }\end{array}$ & $\begin{array}{c}\text { calendar age, } \\
\text { cal yr BP (P=1950) }\end{array}$ & dated material \\
\hline $7-8$ & 123503 & 1605 & 20 & 1071 & benthic foraminifera \\
\hline
\end{tabular}




\begin{tabular}{|c|c|c|c|c|c|}
\hline $31-32$ & 133821 & 1895 & 20 & 1357 & epibenthic foraminifera \\
\hline $51-52$ & 145985 & 2025 & 25 & 1485 & epibenthic foraminifera \\
\hline $81-82$ & 133822 & 2275 & 20 & 1778 & epibenthic foraminifera \\
\hline $106-107$ & 145986 & 2760 & 25 & 2379 & epibenthic foraminifera \\
\hline $127-128$ & 123483 & 3060 & 20 & 2748 & benthic foraminifera \\
\hline
\end{tabular}

\subsubsection{Marine palynological analysis}

Samples for marine palynological analysis were collected at $2 \mathrm{~cm}$ intervals along the core. Three grams of dry sediment were processed following a slightly modified palynological technique (Erdtman 1960; Faegri \& Iversen 1975; Moore et al. 1999; Zonneveld et al. 2009). Samples were dried at $60^{\circ} \mathrm{C}$ for $24 \mathrm{~h}$ and weighed. In order to remove all macro-remains, material was wet sieved over a $150 \mu \mathrm{m}$ mesh sieve. Prior to chemical treatments, a Lycopodium clavatum tablet (Stockmarr 1971) with a known number of spores $(20,848 \pm 1546)$ was added to each sample. For the removal of carbonate, cold hydrochloric acid ( $\mathrm{HCl} 10 \%)$ was added in amounts depending on the intensity of the reaction. The siliceous component was removed by adding cold hydrofluoric acid (HF $72 \%$ ). When samples contained high amounts of sand that could not be removed with a single HF treatment, this step was repeated. After chemical treatment, samples were washed with distilled water and centrifuged for $5 \mathrm{~min}$ at $3500 \mathrm{rpm}$. Each residue was sieved over a nylon $10 \mu \mathrm{m}$ filter in order to remove smaller fractions. No acetolysis or ultrasonic treatment was applied in order to avoid any potential damage of the dinoflagellate cysts and pollen/spores (e.g. Marret et al. 2009). Microscope slides were prepared by embedding the residue in glycerine jelly and isolated from air by a transparent nail polish. Dinoflagellate cysts and pollen/spores were counted using a light microscope (Zeiss Axiostar Plus) at x400 to x1000 magnifications until 150 identified dinoflagellate cysts had been registred.

The taxonomy of dinoflagellate cysts is based on Zonneveld (1997), Fensome \& Williams (2004), Kawamura (2004) and Zonneveld \& Pospelova (2015). Echinidinium spp. includes all spiny brown cysts that could not be identified to species level. Brigantedinium spp. includes all smooth-walled spherical brown cysts without processes (RBC). Spiniferitus hyperacanthus was grouped with Spiniferites mirabilis s.l., cysts of Protoperidinium nudum are grouped with Selenopemphix quanta.

A cumulative dinoflagellate cyst diagram (Figure 2) was created using the TILIA/TILIAGRAPH (Grimm 1987) software. It presents relative abundances of individual dinoflagellate cyst types that were calculated on basis of the total sum of dinoflagellate cysts excluding indeterminate cysts. Cyst groups were established based on their common ecological characteristics and modern geographic distribution patterns (Zonneveld et al. 2013): offshore cysts, costal-water cysts and cosmopolitan cysts. Group sums as well as sums of phototrophic (Figures 3-4) and heterotrophic cysts (Figure 5) 
accompany the relative abundance profiles of single dinoflagellate cyst types. Furthermore, dinoflagellate cysts and pollen/spores concentrations (palynomorphs per gram dry sediment) are given (Figure 2).

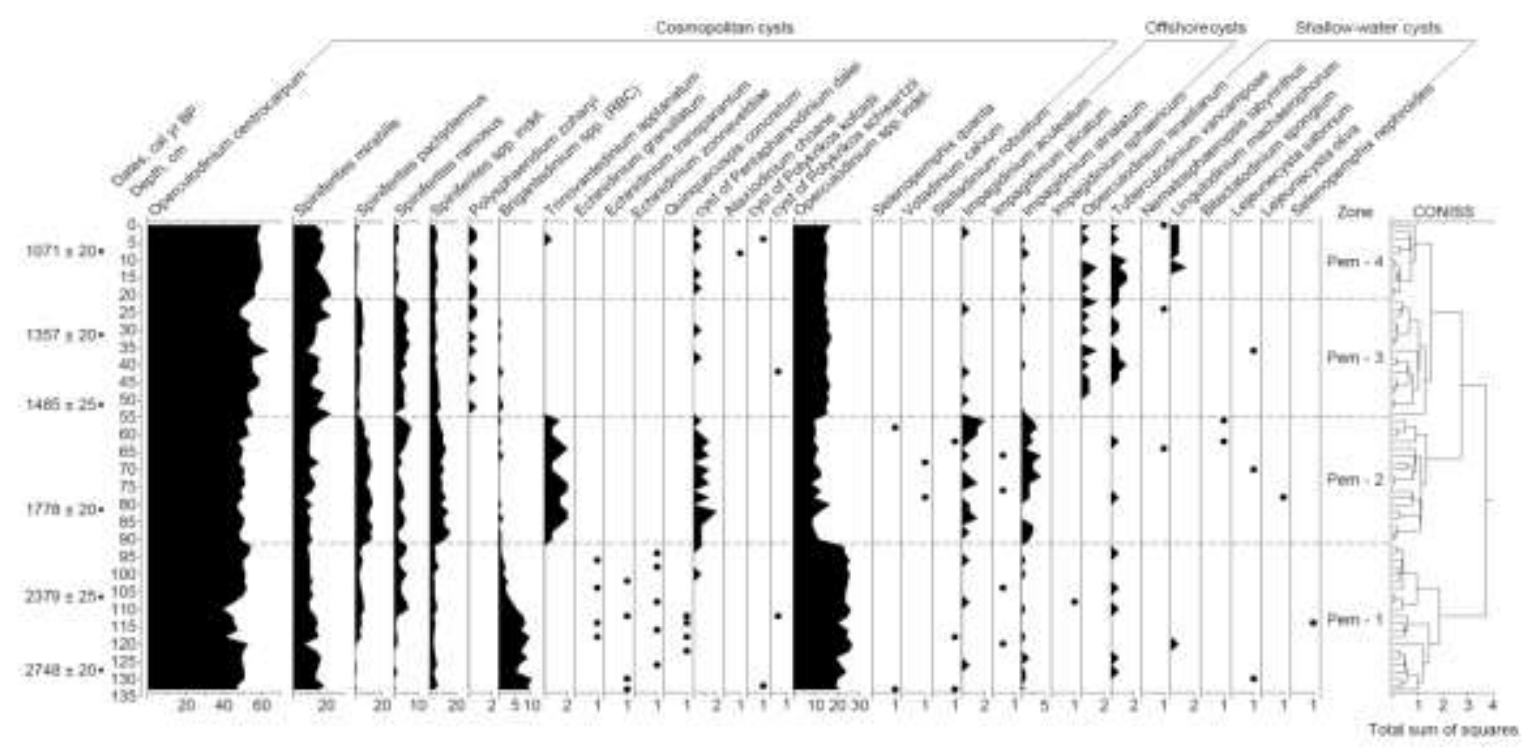

Figure 2. Organic-walled dinoflagellate cyst diagram showing relative abundances of the individual dinoflagellate cysts, sums of cosmopolitan, offshore, coastal-water cysts, phototrophic and heterotrophic species, dry bulk concentrations of dinoflagellate cysts, pollen and fern spores, sedimentation rates and a CONISS cluster-diagram based on total sum of squares. Presence of cysts types contributing to the dinoflagellate cyst total sum less than $2 \%$ on average depicted as black dots.

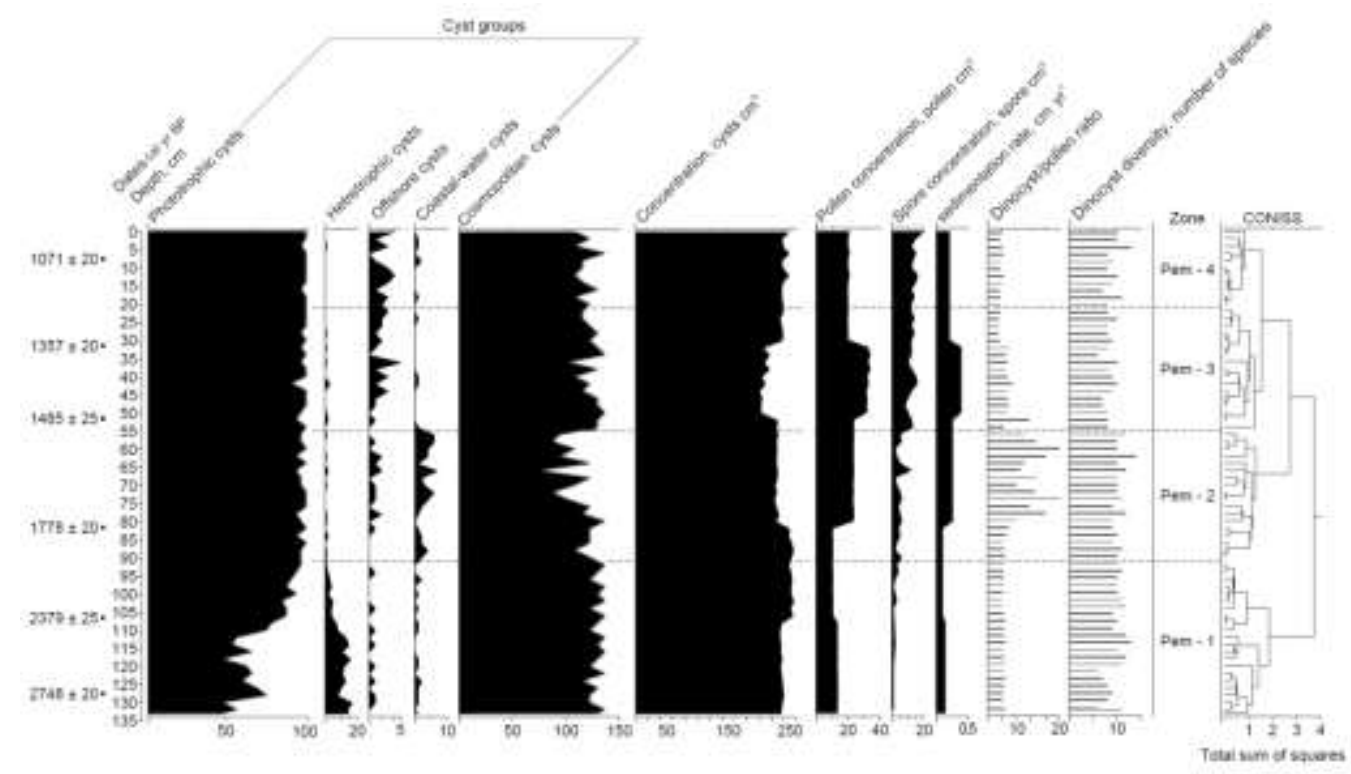

Figure 2. (continuation)

The dinoflagellate cyst record was subdivided into zones that contain successive samples with a common cyst association. Definition of the zones was established by combining empirical observations with the results of constrained cluster analysis by sum-of-squares using CONISS for 
TILIA (Grimm 1987). The stability of the classification and the sharpness of the clusters were tested using the bootstrap resembling performed in MULTIV (Pillar \& Orlóci 1996; Pillar 1999).
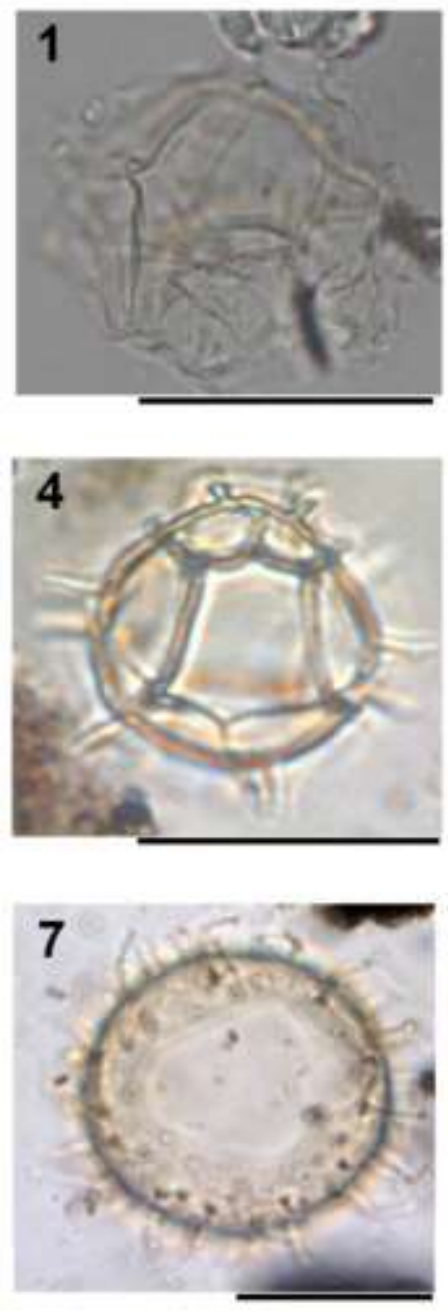
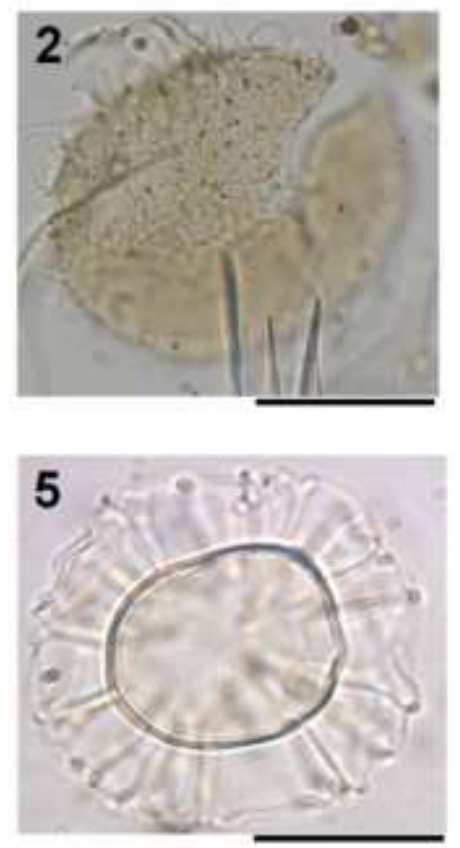

$7 a$
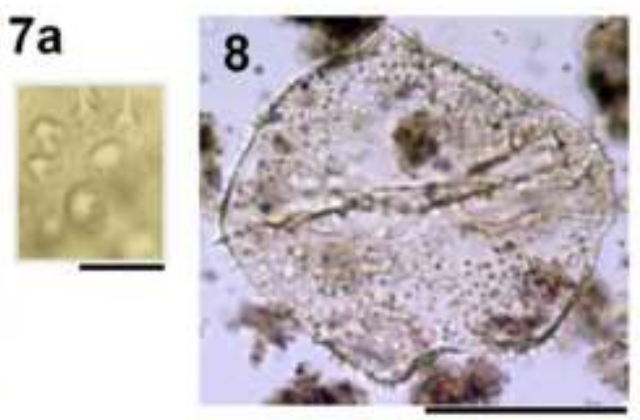
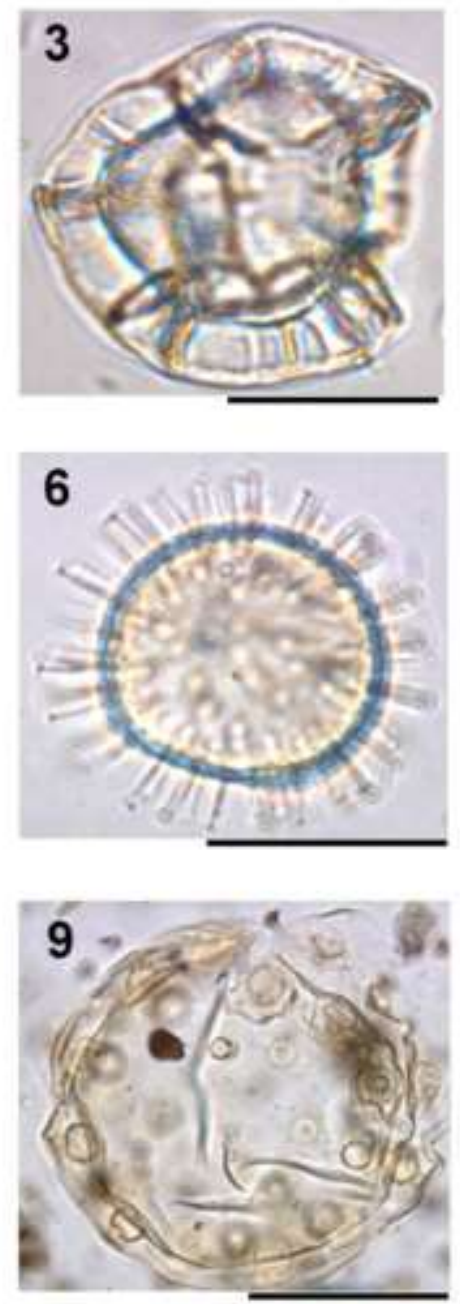

Plate 1. Light microscope photographs of selected phototrophic taxa found in the sediment sequence 1216-23: 1 - Ataxodinium choane Reid 1974; 2 - Bitectatodinium spongium (Zonneveld 1997) Zonneveld et Jurkschat 1999; 3 - Impagidinium strialatum (Wall 1967) Stover et Evitt 1978; 4 Impagidinium aculeatum (Wall 1967) Lentin et Williams 1981; 5 - Nematosphaeropsis labyrinthus (Ostenfeld 1903) Reid 1974; 6 - Operculodinium centrocarpum sensu Wall et Dale 1966; 7 Operculodinium israelianum (Rossignol 1962) Wall 1967; 8 - Trinovantedinium applanatum (Bradford 1977) Bujak et Davies 1983; 9 - Tuberculodinium vancampoae (Rossignol 1962) Wall 1967. Scales bars: $20 \mu \mathrm{m}$.

\subsubsection{Biogeochemical parameters}

For biogeochemical analyses, sediments of a layer in $1-3 \mathrm{~cm}$ resolution were dried at $40{ }^{\circ} \mathrm{C}$ and ground to a fine homogenous powder in a Retsch planetary ball mill PM 100. Samples were analyzed for total carbon $\left(\mathrm{C}_{\text {tot }}\right)$ and total nitrogen $\left(\mathrm{N}_{\text {tot }}\right)$ by high-temperature combustion in a Euro EA 3000 elemental analyzer. Organic carbon $\left(\mathrm{C}_{\text {org }}\right)$ was determined the same way after removal of carbonate by acidification with $1 \mathrm{~N} \mathrm{HCl}$ and subsequent drying at $40^{\circ} \mathrm{C}$. Calcium carbonate contents $\left(\mathrm{CaCO}_{3}\right)$ 
were calculated from inorganic carbon $\left(C_{\text {inorg }}=C_{\text {tot }}-C_{\text {org }}\right.$ ). Measurements had a precision of $0.02 \%$ for $\mathrm{C}_{\text {tot }}, 0.02 \%$ for $\mathrm{C}_{\text {org }}$ and $0.003 \%$ for $\mathrm{N}_{\text {tot }}$, based on repeated measurements of a standard. The carbon and nitrogen stable isotope composition $\left(\delta^{13} \mathrm{C}_{\mathrm{org}}, \delta^{15} \mathrm{~N}\right)$ was determined with a Thermo Finnigan Delta Plus gas isotope ratio mass spectrometer after high temperature combustion in a Flash $1112 \mathrm{EA}$ elemental analyzer. Carbonates were removed prior to the $\delta^{13} \mathrm{C}_{\text {org }}$ analysis by adding $1 \mathrm{~N} \mathrm{HCl}$ and subsequent drying at $40{ }^{\circ} \mathrm{C}$. Values of $\delta^{13} \mathrm{C}_{\text {org }}$ and $\delta^{15} \mathrm{~N}$ are given as \%o-deviation from the carbon isotope composition of the PDB standard and the nitrogen isotope composition of atmospheric air, respectively. The analytical precisions of the methods determined by repeated measurements of internal standards were $0.07 \%$ for $\delta^{13} \mathrm{C}_{\text {org }}$ and $0.09 \%$ for $\delta^{15} \mathrm{~N}$. Biogenic silica was extracted from 15 mg ground sediment subsamples by a method modified from Mortlock \& Froelich (1989) and detected using a Spectro Ametek Ciros Vision ICP-OES (inductively coupled plasma optical emission spectrometry). Raw data of the dinoflagellate cyst counts and biogeochemical data are stored in the PANGEA database: http://pangaea.de

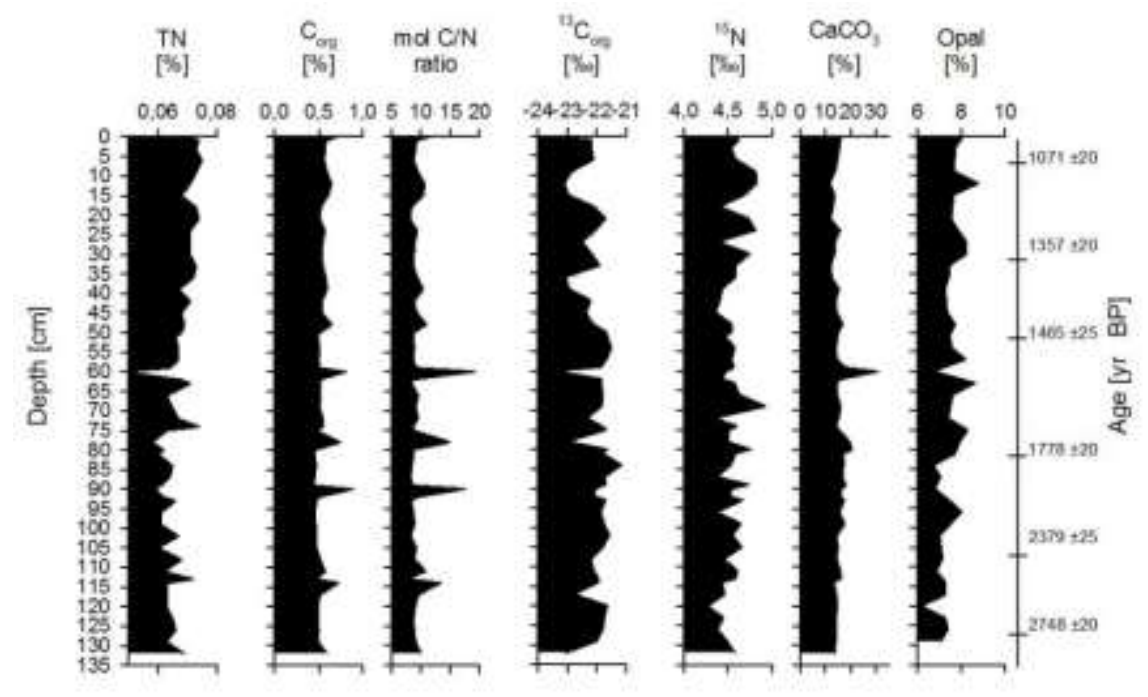

Figure 3. Depth-related changes in total nitrogen content $\left(\mathrm{N}_{\text {tot }}\right)$, organic carbon $\left(\mathrm{C}_{\text {org }}\right), \quad$ stable carbon $\quad\left(\delta^{13} \mathrm{C}_{\text {org }}\right)$ and nitrogen $\left(\delta^{15} \mathrm{~N}\right)$ isotopes, calcium carbonate $\left(\mathrm{CaCO}_{3}\right)$ and biogenic opal throughout the core 1612-23.

\subsubsection{Statistical analysis}

To study the relations between the dinoflagellate cyst relative abundances and the biogeochemical parameters, redundancy multivariate analysis (RDA, Rao 1964) was applied using the CANOCO 5 and CanoDraw software package (ter Braak \& Šmilauer 2002; Šmilauer \& Lepš 2014). All taxonomic data were standardized and logarithmically transformed. The length of the variance gradient was estimated by means of a preliminary detrended correspondence analysis (DCA, Hill and Gauch, 1980). In order to evaluate the significance of the RDA axes, the null hypothesis was tested using the nonparametric Monte Carlo permutation test (Manly 1992). The null hypothesis expects that no relations exist between the variation in relative abundance of the dinoflagellate cyst taxa and biogeochemical sediment parameters. Biogeochemical parameters were tested for linear regressions with depth and correlations with each other using the Spearman test. 

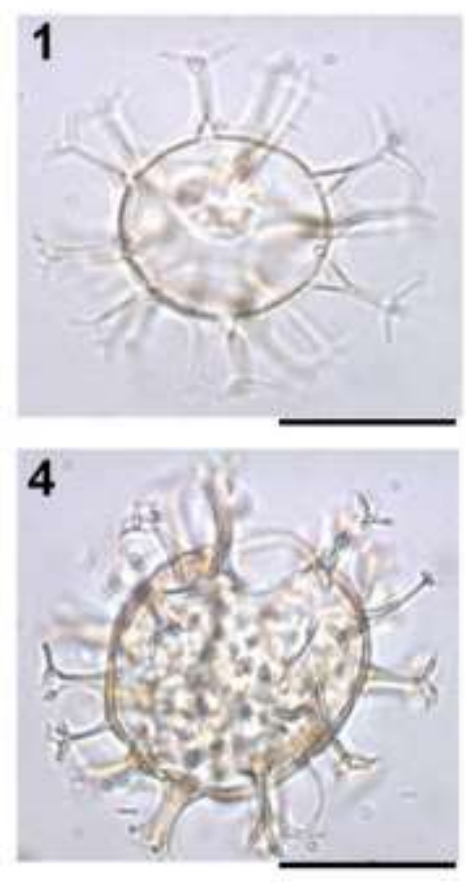
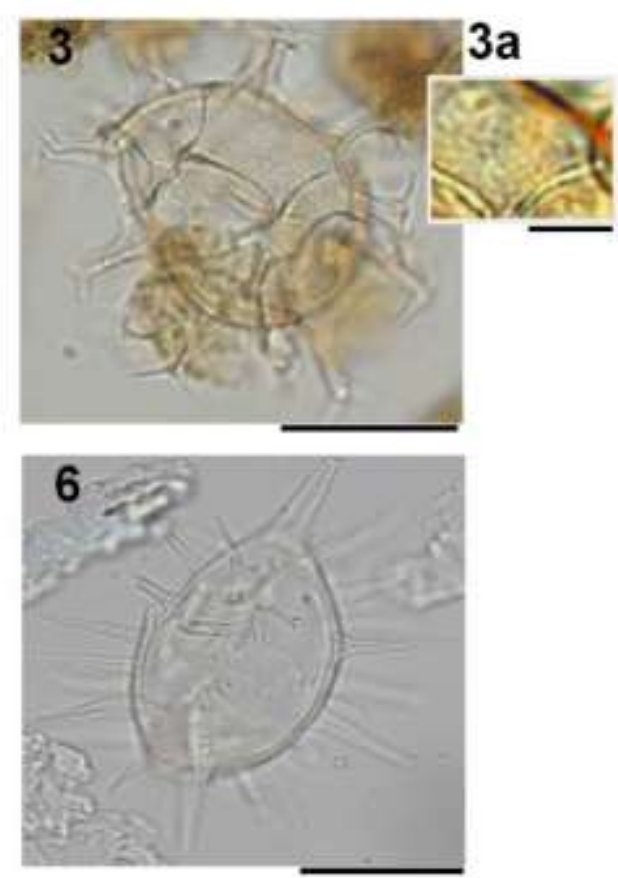

Plate 2. Light microscope photographs of selected phototrophic taxa found in the sediment sequence 1216-23: 1 - Spiniferites ramosus (Ehrenberg 1838) Mantell 1854; 2 - Spiniferites mirabilis (Rossignol 1964) Sarjeant 1970; 3 - Spiniferites pachydermus (Rossignol 1964) Reid 1974; 4, 5 - Spiniferites spp.; 6 - Lingulodinium machaerophorum (Deflandre \& Cookson 1955) Wall 1967. Scales bars: $20 \mu \mathrm{m}$.

\subsection{Results}

\subsubsection{Age-depth model and sedimentation rate}

Extrapolation of the dates suggests that the base of the core (at $133-134 \mathrm{~cm}$ ) is as old as about 2850 cal yr BP. The uppermost layer $(0-1 \mathrm{~cm})$ dates back to $990 \mathrm{cal}$ yr BP. Estimated sedimentation rates vary along the core from low rates of $0.4-0.5 \mathrm{~mm} \mathrm{yr}^{-1}$ (between 134 and $81 \mathrm{~cm}$ ) to relatively high rates of $\sim 1 \mathrm{~mm} \mathrm{yr}^{-1}$ (between 81 and $51 \mathrm{~cm}$ ) and $\sim 1.6 \mathrm{~mm} \mathrm{yr}^{-1}$ (between 52 and $32 \mathrm{~cm}$ ) decreasing to $\sim 0.8 \mathrm{~mm} \mathrm{yr}^{-1}$ in the upper part of the core $(32-0 \mathrm{~cm})$. From 90 to $50 \mathrm{~cm}$, the sand content increases, whilst after $50 \mathrm{~cm}$ towards the top it slightly decreases again.

\subsubsection{Dinoflagellate cyst stratigraphy}

\subsubsection{General patterns}

Based on the taxonomic composition of the dinoflagellate cyst association supported by CONISS analyses, four distinct dinoflagellate zones are described (Pem-1 to Pem-4, Figure 2). Despite being suggested by the cluster analysis, no additional subzones in Pem-1 and Pem-3 are derived as the species composition change of these subzones is not significant $(p>0.05)$ and the probability ( $P$; $1 \leq P>0)$ for two given sub-clusters was low: $P=0.45$ (Pem-1) and $P=0.3$ (Pem-3; Pillar, 1999). These 
sub-zones are, therefore, not presented in the diagrams and are not considered for the further analysis.
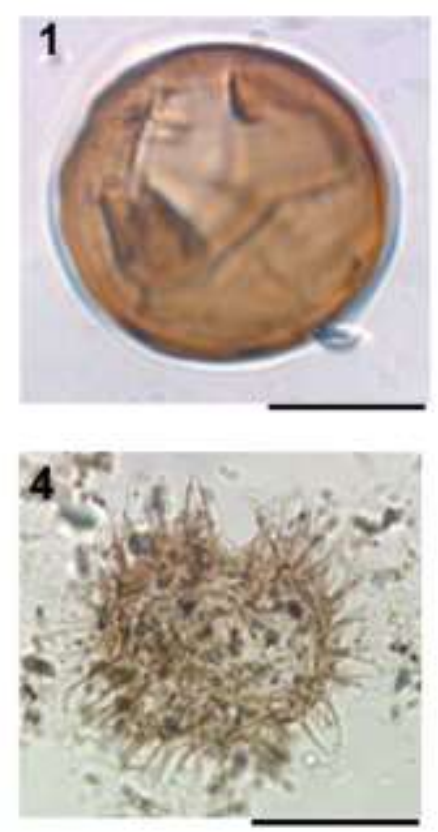
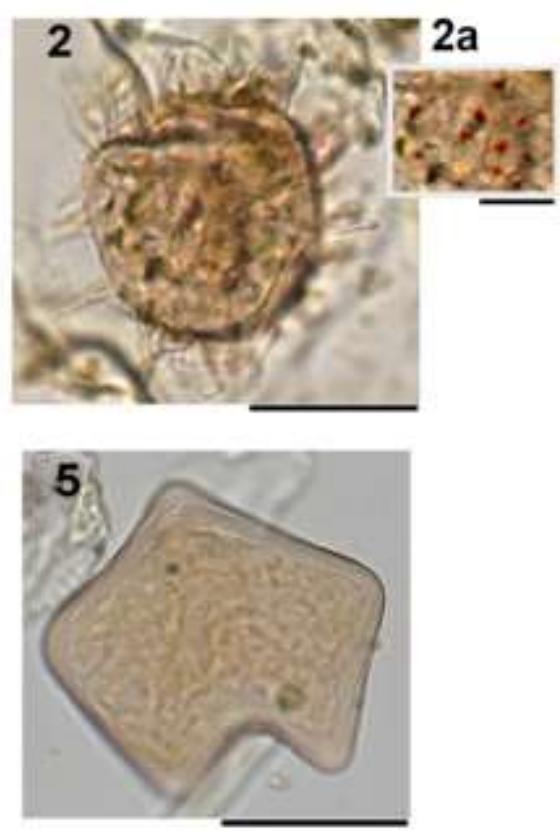
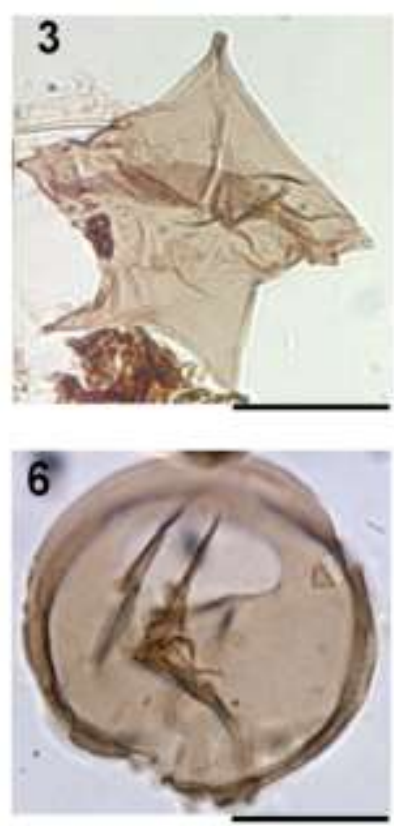

Plate 3. Light microscope photographs of selected heterotrophic taxa found in the sediment sequence 1216-23: 1 - Brigantedinium sp. (RBC) Reid 1977 ex Lentin et Williams 1993; 2 Echinidinium transparantum Zonneveld 1997; 3 - Stelladinium robustum Zonneveld 1997; 4 Selenopemphix quanta (Bradford 1975) Matsuoka 1985; 5 - Votadinium calvum Reid 1977; 6 Selenopemphix nephroides (Benedek 1972) Benedek et Sarjeant 1981. Scales bars: $20 \mu \mathrm{m}$.

Most of the dinoflagellate cyst association is composed of warm water and fully marine cysts, predominantly by the transparent oxidation-resistant species of the genera Operculodinium and Spiniferites with minor contributions of Impagidinium (mainly Impagidinium strialatum) and brown coloured oxidation-sensitive cysts, both round (i.e. Brigantedinium spp.) and spiny (Echinidinium spp.) as well as various other but not well preserved peridinoid dinoflagellate cysts. The amount of pollen and fern spores is low, 256 pollen grains $\mathrm{g}^{-1}$ and 20 spores $\mathrm{g}^{-1}$ at maximum, respectively.

\subsubsection{Zone description}

\section{Zone Pem-1 (134-91 cm; 11 samples)}

Sediments of this zone were deposited between ca 2850 and ca 2480 cal yr BP (Figure 2). The dinoflagellate cyst association is dominated by oxidation-resistant species ( 70\%) with Operculodinium centrocarpum contributing almost a half of the total amount (about 50\%). Spiniferites mirabilis forms about $12 \%$ of the association. Spiniferites pachydermus and Spiniferites ramosus contribute $3 \%$ each. Impagidinium strialatum and Tuberculodinium vancampoae occur 116 
regularly but contribute less than $1 \%$. Values of the oxidation-sensitive cysts are generally low but compared to the other zones form the highest for the entire record ( $10 \%)$ with round brown cysts (Brigantedinium spp.) being most dominant ( $\sim 5 \%)$. Echinidinium species are restricted to this zone where they are constantly present. At the depth interval between Quinquecuspis concreta occurs

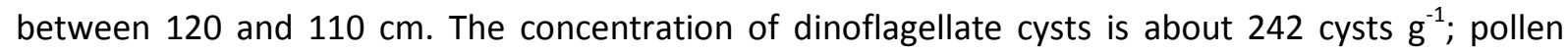
concentration is very low, $\sim 12$ pollen $\mathrm{g}^{-1}$.

\section{Zone Pem-2 (91-55 cm; 17 samples)}

Sediments were deposited between ca 2480 and ca 1530 cal yr BP. The cyst association displays a slight increase in oxidation-resistant cysts ( $75 \%$, Figure 2 ) due to the increase in the proportions of S. pachydermus ( $10 \%$ ) and Impagidinium species ( 3\%). Values of $O$. centrocarpum, S. mirabilis and S. ramosus stay almost unchanged, being about $50 \%, \sim 10 \%$ and $\sim 2 \%$ of the association respectively. In this zone, occurrences of $T$. vancampoae are rare. Trinovantedinium applanatum as well as the cysts of Pentapharsodinium dalei contribute together $\sim 2 \%$ of the association. Oxidation-sensitive cysts contribute $\sim 3 \%$ only and are almost exclusively formed by Brigantedinium spp. ( $2 \%)$. Some single specimens of peridinioid cysts are registered sporadically in the samples. The concentration of

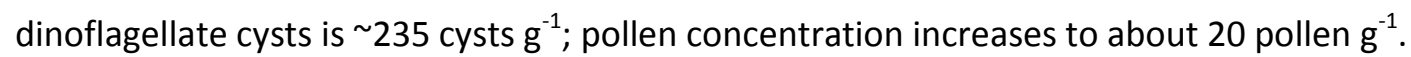

\section{Zone Pem-3 $(55-21 \mathrm{~cm} ; 11$ samples)}

Sediments were deposited between ca 1530 and ca 1250 cal yr BP. In this zone, again an increase in oxidation-resistant cysts ( 78\%) is observed. Values for O. centrocarpum ( $60 \%$, Figure 2 ) and $S$. mirabilis ( $15 \%)$ slightly increase, while the proportions of S. pachydermus $(\sim 4 \%)$ decrease markedly. Above $50-45 \mathrm{~cm}, O$. israelianum, $P$. zoharyi and $T$. vancampoae occur regularly as compared to Impagidinium species which are seldom observed. The heterotrophic species $T$. applanatum is not seen in this zone. The proportion of oxidation- sensitive cysts decreases to $1 \%$ due to the decrease in Brigantedinium spp. The concentration of dinoflagellate cysts decreases to $\sim 218$ cysts ${ }^{-1}$, whilst pollen concentration slightly increases $\left(\sim 28\right.$ pollen $\left.\mathrm{g}^{-1}\right)$.

\section{$\underline{\text { Zone Pem-4 (21-0 cm; } 11 \text { samples) }}$}

Sediments were deposited between ca 1250 - 990 cal yr BP. They are characterized by a strong dominance of oxidation-resistant cysts (up to $80 \%$, Figure 2) with a high abundance of $O$. centrocarpum (about 60\%) and S. mirabilis ( 17\%). Values for S. pachydermus decrease to 2\%; S. ramosus and $T$. vancampoae occur regularly unlike $T$. applanatum, which is only sporadically present. 
Impagidinium species contribute less than $1 \%$ to the association. From a depth of $15 \mathrm{~cm}$ upwards, Lingulodinium machaerophorum is constantly present. Oxidation-sensitive cysts contribute only 2\% to the association and have a disruptive profile in this zone. The concentration of dinoflagellate cysts is $\sim 240$ cysts $\mathrm{g}^{-1}$; pollen concentration is $\sim 20$ pollen $\mathrm{g}^{-1}$.

\subsubsection{Biogeochemical profiles}

Contents of $N_{\text {tot }}$ and $C_{\text {org }}$ in the sediments (Figure 6) is overall relatively low (mean $\pm S D N_{\text {tot }}$ : $\left.0.07 \pm 0.02 \% ; C_{\text {org }}: 0.55 \pm 0.09 \%\right)$. Contents of $N_{\text {tot }}$ decrease with depth $\left(r^{2}=0.34, p<0.0001\right)$. At $60 \mathrm{~cm}$, $78 \mathrm{~cm}, 90 \mathrm{~cm}$ and $114 \mathrm{~cm}, \mathrm{C}_{\text {org }}$ contents are elevated and $\mathrm{N}_{\text {tot }}$ contents decrease. The molar $\mathrm{C} / \mathrm{N}$ ratios, which are usually around 10 , increase to values between 14 and 18 (Figure 6 ); $\delta^{13} C_{\text {org }}$ values are usually around $-22 \%$ and are lower (-23 to $-24 \%$ ) at the depths mentioned above as well as at 12 $\mathrm{cm}$ and $36 \mathrm{~cm}$. There are strong negative correlations of $\delta^{13} \mathrm{C}_{\text {org }}$ with the $\mathrm{C} / \mathrm{N}$ ratios (Spearman, $\mathrm{r}^{2}=-$ $0.71, p<0.001$ ) and with $C_{\text {org }}$ contents (Spearman, $\left.r^{2}=-0.78, p<0.001\right) ; \delta^{15} \mathrm{~N}$ displays only small variability (mean \pm SD: $4.5 \pm 0.1 \%$ ). Carbonate contents are mostly around $15 \%$ with exception of those at $60 \mathrm{~cm}$ and $78 \mathrm{~cm}$ (Figure 6), where they amounted to $30 \%$ and $20 \%$, respectively. Biogenic opal contributes usually $7-8 \%$ and displays a slight increase towards the top (linear regression analysis: $\left.\mathrm{r}^{2}=0.27, \mathrm{p}<0.001\right)$. Biogenic opal contents were always lower than $\mathrm{CaCO}_{3}$ contents.

\subsubsection{Results of multivariate analysis}

After DCA had revealed a gradient of 1.5 standard deviation (SD), RDA redundancy analysis (RDA) was applied as recommended by Šmilauer \& Leps (2014) for data sets with short environmental gradients (i.e. environmental gradients less than 2 SD). The first two dimensions of the RDA (Figure 7) account for $48 \%$ and $12 \%$ of the total variance of dinoflagellate cyst taxa and biogeochemical data. The ratio $\lambda 1+\lambda 2$ / total variance, a measure of the goodness of fit equivalent to $R^{2}$ (Jongman et al. 1987), is 0.84 . The relative distance between samples explains the differences in dinoflagellate cyst composition.

As it is shown (Figure 7A), most of brown-coloured heterotrophic dinoflagellate cysts (e.g. Brigantedinium spp., Echinidinium granulatum, Echinidinium transparantum, Echinidinium zonneveldiae) are positively correlated with $\delta^{13} \mathrm{C}_{\text {org }}$ and are negatively correlated with opal content and most of the abundant phototrophic cysts. Operculodinium centrocarpum, Operculodinium israelianum, Polysphaeridium zoharyi, Spiniferites mirabilis and Tuberculodinium vancampoae are correlated with $\mathrm{N}_{\text {tot }}$ and $\delta^{15} \mathrm{~N}$. Impagidinium species, Spiniferites pachydermus, Spiniferites spp., and Trinovantedinium applanatum are in accordance with $\mathrm{C}_{\mathrm{tot}}, \mathrm{CaCO}_{3}$ and $\mathrm{C} / \mathrm{N}$ ratio that are strongly correlated between each other, whereas Spiniferites ramosus turn out to be strongly correlated with 
$\mathrm{C}_{\text {org. }}$. All others (Figure 7A) are weakly correlated to other species and presented low abundances in the dinoflagellate cyst assemblages throughout the sequence.
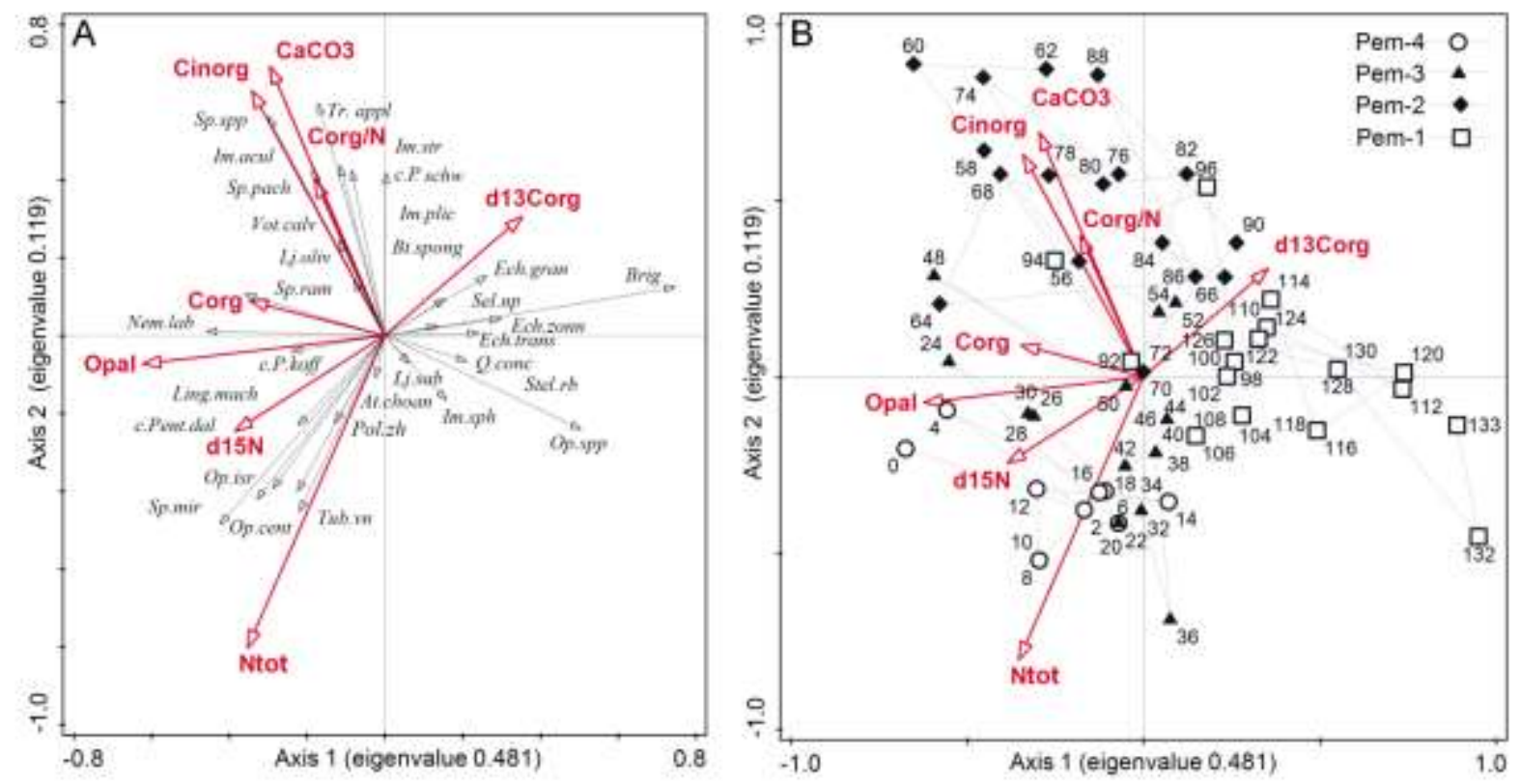

Figure 7. Results of RDA analysis illustrating dinotypes in relation to biogeochemical environmental variables. Biogeochemical parameters are abbreviated as indicated in text. Dinoflagellate cyst types are indicated as following: At.choan - Ataxodinium choane, Brig - Brigantedinium spp. (RBC), Bt.spong - Bitectatodinium spongium, c.P.koff - Cyst of Polykrikos kofoidii, c.Pent.dal - cyst of Pentapharsodinium dalei, c.P.schw - cyst of Polykrikos schwartzii, Ech.gran - Echinidinium granullatum, Ech.trans - Echinidinium transparantum, Ech.zonn - Echinidinium zonneveldiae, Im.str Impagidinium strialatum, Im.acul - Impagidinium aculeatum, Im.plc - Impagidinium plicatum, In.sph Impagidinium sphaericum, Ling.mach - Lingulodinium machaerophorum, Lj.oliv - Lejeunecysta oliva, Lj.sab - Lejeunecysta sabrina, Nem.lab - Nematosphaeropsis labyrinthus, Op.cent - Operculodinium centrocarpum, Op.izr - Operculodinium israelianum, Op.spp - indeterminate Operculodinium spp., Pol.zh - Polysphaeridium zoharyi, Q.conc - Quinquecuspis concretum, Sel.np - Selenopemphix nephroides, Sel.rb - Stelladinium robustum, Sp.mir - Spiniferites mirabilis, Sp.pach - Spiniferites pachydermus, Sp.ram - Spiniferites ramosus, Sp.spp - indeterminate Spiniferites spp., Tr. appl Trinovantedinium applanatum, Tub.vn - Tuberculodinium vancampoae, Vot.calv - Votadinium calvum.

Monte Carlo permutations with specific restrictions for time-series analysis were used for both tests concerning only the first RDA axis and a second test including all eigenvalues. Both tests reject the null hypothesis implying that no relation exists between species and the environmental variables at $3.5 \%$ level of significance.

Figure 7B shows a positive relations for the most of samples from the lowest dinoflagellate cyst zone $(P e m-1,134-92 \mathrm{~cm})$ to $\delta^{13} \mathrm{C}_{\text {org }}$ with exception of samples collected from the core depths $116-118 \mathrm{~cm}$ and $128-132 \mathrm{~cm}$. These samples have a high percentage of damaged, broken and therefore undistinguished Operculodinium spp., sample from $96 \mathrm{~cm}$ because of its high content of $\mathrm{C}_{\text {org }}$ and samples from the depths $94-92 \mathrm{~cm}$ probably due to their increased opal content. Samples from the 
dinoflagellate cyst zone Pem-2 $(90-56 \mathrm{~cm})$ are heterogeneous and show poor correlation with the geochemical parameters. Samples from the dinoflagellate cyst zone Pem-3 $(55-21 \mathrm{~cm})$ are correlated with $\mathrm{CaCO}_{3}$ and $\mathrm{C} / \mathrm{N}$ ratio, and samples from the dinoflagellate cyst zone Pem-4 $(20-0 \mathrm{~cm})$ with the opal content, $\mathrm{N}_{\text {tot }}$ and $\delta^{15} \mathrm{~N}$. Moreover, samples from the lowest and the highest dinoflagellate cyst zones are correlated negatively with each other.

\subsection{Interpretation and Discussion}

\subsubsection{Taxonomic composition of dinoflagellate cyst assemblages}

The organic-walled dinoflagellate cyst assemblages observed in this study are typical for tropical open marine and shallow water environments that are characterized by a relatively low productivity and strong water ventilation (e.g. Marret \& Zonneveld 2003; Zonneveld 2013). It is comparable to assemblages observed in other coastal waters in Indonesia, intercontinental shelves and estuaries in other tropical regions of the world such as e.g. the Caribbean Sea, the Yucatan channel, the Bahamas, the Mississippi Sound, Tampa Bay, Gulf of Mexico and a few estuaries in Vietnam (Deflandre \& Cookson 1955; Wall \& Dale 1977; Head \& Westphal 1999; Matsuoka et al. 1999; Edwards \& Willard 2001; van Soelen et al. 2010; Limoge 2013).

Our results are mainly in agreement with the "Checklist of dinoflagellate cysts found in the surface sediment samples from the Gulf of Thailand and the East Coast of Peninsular Malaysia" and with species list made for upper Sabah, Sarawak and Brunei Darussalam waters (Lirdwitayaprasit 1997, 1998). It is also in consonance with the dinoflagellate cyst species list compiled for surface sediments of the tropics and Southeast Asian waters by Furio et al. (2012). We observed, however, two to three times lower diversity along the heterotrophic species. Registrations of so-called causative species of paralytic shellfish poisoning or harmful algal blooms in this study are doubtful as the result of the preservation state of cysts in the downcore sediments, with cell content being degraded hampering detailed determination. For instance, for downcore material it is impossible to distinguish between different toxic Alexandrium species as the discriminating criteria focus on cell organelles and structures. An exception is the paralytic shellfish poisoning species Polysphaeridium zoharyi (thecabased name is Pyrodinium bahamense var. compressum (Böhm) Steidinger, Tester et Taylor). This species is reported by Matsuoka et al. (1999) in sediment surface samples from Jakarta Bay (Java), Larantuka (Flores) and Ujung Pandang (Sulawesi). In our samples, P. zoharyi is observed only in sediments deposited after ca 1485 BP which might suggest the introduction of this species in the research area at this time. Although, abundances of this species never exceed $1-2 \%$ of the total dinoflagellate cyst sum (i.e. concentrations of less than 20 cells $\mathrm{g}^{-1}$ ) which makes it unlikely that this species might have induced water poisoning events in the study area. 
In surface sediments along the coast of northwest to Western Australia and Indonesia, the occurrence of relatively high relative abundances of $O$. centrocarpum and Impagidinium species is typical for open marine water sites (Hessler et al., 2013). The high relative abundances of these species in the 1612-23 core sediments throughout the studied time interval suggest an open marine environmental setting of the core site.

Hessler et al. (2013) document high relative abundances of Spiniferites spp., S. mirabilis and S. ramosus in surface sediments of western and eastern Indonesia characterized by high surface water temperatures and low nutrient concentrations. A predominant role of Spiniferites species from $10 \mathrm{kyr}$ ago was indicated by Murgese et al. (2008) for relatively shallow waters of the Sunda Shelf (Kawamura 2004) and for the coastal waters of Sabah, Malaysia (Furio et al. 2006). These species are among the most abundant species in core 1612-23, suggesting warm upper water-column temperatures at the study site throughout the studied time interval.

\subsubsection{Primary production and aerobic decomposition of dinoflagellate cysts}

The slight increase in bulk dry concentrations of dinoflagellate cysts and in opal concentrations may point to development of favorable conditions for maintaining high primary production in the Java Sea between ca 2850 and 990 cal yr BP. This would result in a better food base for heterotrophic dinoflagellates and it can therefore be expected that a trend of increase in abundance of cyst of heterotrophic species (e.g. peridinoid cysts, Echinidinium species and in Brigantedinium spp.) should occur over time. However, we do no observe this. On the contrary, we observe a decreasing diversity trend of heterotrophic dinoflagellate cyst species followed by sharp decrease of their total absolute and relative abundances (Figure 2).

Organic-walled dinoflagellate cysts have a remarkable physical and chemical resistance (Kokinos et al. 1998). However, recent studies have shown that the macromolecular wall composition of the cyst is species-specific with some species being extremely sensitive to aerobic degradations, whereas others are extremely resistant (e.g. Versteegh 2012; Bogus et al. 2012, 2014). It has been shown that that cyst concentrations of many peridinioid species, Echinidinium spp., and Brigantedinium spp. can vary not only as the result of change in upper water-column primary production, but also from postdepositional selective preservation, which is related to bottom/pore water oxygen concentrations (e.g. Versteegh \& Zonneveld 2002; Zonneveld et al. 2007; Zonneveld \& Brummer 2000). Hence, the decrease in abundances of Brigantedinium spp., Echinidinium spp. and peridinioid dinoflagellate cysts in our samples from $2350 \mathrm{cal}$ yr BP $(105 \mathrm{~cm})$ onwards, might have been a consequence of aerobic dinoflagellate cyst decomposition rather than changes in upper water bio-productivity. 


\subsubsection{Reconstruction of changes in the marine environment}

\section{Pem-1: ca 2850 - 2480 cal yr BP}

This phase is characterized by a dinoflagellate cyst association that is mainly composed of cosmopolitan species (i.e. Operculodinium centrocarpum, Spiniferites ramosus, S. pachydermus, Spiniferites spp. and Operculodinium spp.). To date, these species are found in regions where surface water has a broad range of SST, SSS and trophic conditions (Zonneveld et al. 2013). High values of Spiniferites mirabilis suggest warm water and fully marine conditions at the core site throughout this time interval (Marret \& Zonneveld 2003; Zonneveld et al. 2013). The occurrences of the typically open water species Impagidinium strialatum suggest that waters from open marine environments reached the core site (e.g. Edwards \& Andrle 1992; Zonneveld et al. 2009).

A very low pollen concentration and the almost absence of fern spores in sediments of this zone suggest a limited terrestrial input from the river Pembuang between ca 2850 and $2480 \mathrm{cal}$ yr BP. The $\mathrm{C} / \mathrm{N}$ ratio is usually around 10 , exceeding somewhat that of plankton (6.6) but is lower than that of suspended organic matter carried by peat draining rivers into the Java Sea (16.6) (Baum \& Rixen, 2014). This suggests that although the organic material at the sea floor contains of a mixture of terrestrial and marine produced organic matter, the majority of $\mathrm{OM}$ found in the sediments has a marine origin. This is corroborated by $\delta^{13} \mathrm{C}_{\text {org }}$ values that vary around $-22 \%$, which are at the lower end of the range of values typical for tropical marine phytoplankton (-18 to $-22 \%$; e.g. Fischer et al. 1991). Biogenic opal contents are lower than contents of $\mathrm{CaCO}_{3}$ that indicates that the plankton is dominated by foraminifera and coccolithophores, rather than by diatoms and dinoflagellates. This suggests that a quite low productivity regime has existed at the core site during this time interval.

\section{Pem-2: ca $2480-1530$ cal yr BP}

Compared to the previous phase, the composition of the dinoflagellate cyst association has changed notably. The decrease in values of heterotrophic peridinioid, Echinidinium and Brigantedinium species suggests increased organic matter degradation which can be interpreted as being the result of a better ventilation of the bottom waters. Increased abundance of Trinovantedinium applanatum that 'in the region and other parts of the world has its maximal occurrences in upwelling areas and in river plumes regions where large inter-annual variability in the upper water trophic state can occur' (Zonneveld et al. 2009) suggest that more coastal waters reached the core position. This is also in consistence with the somewhat higher pollen concentrations found in this zone.

Sea-level reconstructions by Griffiths et al. (2009; see Figure 2) based on Red Sea benthic foraminifera and Barbados and Tahiti coral reef studies indicate that sea-level fluctuated remarkably 
in the region after ca 4000 cal yr BP. Particularly between ca 2000 and 3000 cal yr BP, a slight decrease in sea-level is reconstructed that might suggest that the core site might have become more neritic and surface waters became under influence of more coastal water masses. The presence of relatively high abundances of Impagidinium species throughout this zone implies that the core site was influenced by open sea waters as well. These waters might have been flowing to the core site through the Karimata Strait Throughflow that is the strongest surface current in the area connecting the South China Sea and the Java Sea (e.g. Wirtki 1961; Fang 2010; He et al. 2015). Contemporaneous with increased relative and absolute abundances of Trinovantedinium applanatum, three events of distinctly higher $\mathrm{C} / \mathrm{N}$ ratios and lower $\delta^{13} \mathrm{C}_{\text {org }}$ values are observed. This suggests a higher contribution of allochthonous organic matter at these intervals. It is likely that this is caused by enhanced discharge of terrestrial organic matter from the Pembuang River, due to e.g. floods or short wet periods.

\section{Pem-3: ca 1530 - 1250 cal yr BP}

In this period an increased contribution of typically lagoon and shallow waters species can be observed in the dinoflagellate cyst association (notably Operculodinium israelianum, Polysphaeridium zoharyi and Tuberculodinium vancampoae, e.g. Wall \& Dale 1969; Limoges 2013). This suggests that coastal waters more pronouncedly influenced the core site. This is in agreement with the decline in abundances of the typical offshore species Impagidinium aculeatum and I. strialatum as well as the somewhat higher concentrations of pollen/spores found in this zone. A stronger influence of coastal water might have enhanced the trophic conditions in the surface waters and as such bio-productivity. This is reflected by higher biogenic opal contents and $\delta^{15} \mathrm{~N}$ values around $1350 \mathrm{cal}$ yr BP. A stronger influence of coastal waters on the study site might have been the result of either increased river discharge on the nearby island, or a sea level lowering.

Holocene sea-level reconstructions in SE Asia are limited and fragmentary and often controversial (Woodroffe and Horton, 2005). It is suggested that one (e.g. Geyh \& Kudrass 1979; Woodroffe and McLean 1990; Scoffin \& Le Tissier 1998; Hanebuth et al. 2000) to three (Tija 1996) Holocene high water stands occurred. However, all these events were subscribed for much earlier time intervals (from 8000 to $2700{ }^{14} \mathrm{C}$ yr BP the latest) compared to the changes observed here. Griffiths et al. (2009) postulated a slight increase in sea level between ca 2000 and 1500 cal yr BP followed by a small decrease until the modern level was reached. However, all these studies indicate sea level fluctuated during the time frame of this zone only between $0.5-1 \mathrm{~m}$, which is not enough to explain the differences in palynological and biogeochemical signals observed at the study site.

For the nearby Banda Sea (core G5-2-56P), Ganssen et al. (1989) reconstructed that productivity in their study area decreased after 1500 cal yr BP and concluded it to be a result of a weakening of the 
monsoonal regime. Additionally, Reeves et al. (2013a and related references; 2013b) indicated increasing changes in the environment and enhanced drier overall conditions of the Australasian region between 5000 and 0 cal yr BP, indicative of ENSO in El Niño mode with more extreme El Niño events compared with present. We therefore assume that changes in composition of dinoflagellate cyst assemblages in the Java Sea after ca 1530 cal yr BP are likely to be forced by change in precipitation changes, probably related to short-scale seasonal differences between dry and wet periods, rather than by the sea level change.

\section{Pem-4: ca 1250 - 990 cal yr BP}

The occurrence of nutrient-sensitive Lingulodinium machaerophorum and Nematosphaeropsis labyrinthus and the typical coastal species Tuberculodinium vancampoae suggest that an increased amount of coastal and/or river plume waters reached the study site. This might be related to an increased Pembuang River discharge. This is corroborated by biogeochemical data. Lower $\delta^{13} \mathrm{C}_{\text {org }}$ values indicate higher inputs of terrestrial organic matter. This also makes slightly higher nutrient discharge from the Pembuang River likely. Elevated contents of biogenic opal indicate a temporarily enhanced contribution of diatoms in the phytoplankton suggesting higher productivity during this period. Moreover, increased primary productivity also resulted in a slight increase in the dinoflagellate cyst concentrations. Slight increases in $\delta^{15} \mathrm{~N}$ values point to more efficient nutrient uptake and enhanced productivity, hence less isotopic fractionation.

\subsection{Summary and conclusions}

This study provides a reconstruction of palaeoenvironmental conditions in the Java Sea between ca 2850 and 990 cal yr BP. Study of marine palynomorphs and biogeochemical analysis as two independent methods were used to study a sediment core 1612-23 obtained off the Pembuang River mouth (SE Kalimantan, Indonesia). A low sedimentation rate throughout the sequence $(0.8-1.6 \mathrm{~mm}$ $\mathrm{yr}^{-1}$ ) together with a low $\mathrm{C}_{\text {org }}$ content $(0.4-0.9 \%)$ and very low pollen and spore concentrations (256 pollen grains $\mathrm{g}^{-1}$ and 20 spores $\mathrm{g}^{-1}$ at maximum) suggest open marine conditions with relatively low terrestrial input throughout the studied time period (Schulz \& Zabel 2000).

The sedimentary sequences reveal four major units corresponding to distinct environmental changes. For the first unit, dinoflagellate cyst assemblages suggest stable warm water conditions between ca 2850 and $2480 \mathrm{cal}$ yr BP, which are similar to the present day environment in the study area. In the second zone, after $2480 \mathrm{cal} \mathrm{yr} \mathrm{BP}$, stronger water ventilation was evidenced. The third zone is characterized by the increase in more coastal water masses reaching the core position between 1530 and $1250 \mathrm{cal}$ yr BP. This might have been the result of El Niño-induced seasonal differences between dry and wet periods of the year. In the latest zone between ca 1530 - 990 cal yr BP, a slight increase 124 
in primary productivity was reconstructed that is probably related to an increased Pembuang River discharge.

\subsection{Acknowledgements}

Field material for this research was retrieved during the scientific cruise of the RV "Baruna Jaya" in 1995. The authors express their gratitude to the crew, scientific and technical assistants for their help. We thank Uta Nüsse-Hahne, Mirijam Kiggen, Johanna Brockhaus (University of Göttingen), Olaf Winkler, Andres Stucke, Clarissa Karthäuser and Dorothee Dasbach (Leibniz Center for Tropical Marine Ecology, ZMT) for assistance in the laboratory. Dr. Mahyar Mohtadi (Centre for Marine Environmental Sciences, MARUM, Bremen) and Ricardo De Pol-Holz (Universidad de Concepción, Barrio Universitario, Chile) are acknowledged for providing $\mathrm{C}^{14}$ dating. Cornelia Kwiatkowski has our regards for data calibration. Dr. Tim Rixen (ZMT) is cordially thanked for his critical reading of the manuscript and for his valuable suggestions. All SPICE III - CAFINDO (Bremen-Göttingen) group is thanked for discussions. Jörg Christiansen (University of Göttingen) gets our thanks for his computer assistance. This work was supported by the German Federal Ministry of Education and Research (Bundesministerium für Bildung und Forschung - BMBF) under Grants 03F0645B and 03F0645C for the project SPICE III - CAFINDO.

\subsection{Disclosure statement}

No potential conflict of interest was reported by the author.

\subsection{Supplemental data}

Supplemental data for this article can be accessed here: PANGEA database www.pangaea.de under the name of correspondence author.

\subsection{References}

Aldrian E, Susanto RD. 2003. Identification of three dominant rainfall regions within Indonesia and their relationship to sea surface temperature. International Journal of Climate. 23 (12): 1435-1452. doi:10.1002/joc.950.

Anderson JAR, Müller J. 1975. Palynological study of a Holocene peat and a Miocene coal deposit from NW Borneo. Review of Palaeobotany and Palynology. 19: 291-351.

Anshari G, Kershaw AP, van Der Kaars S, Jacobsen G. 2004. Environmental change and peatland forest dynamics in the Lake Sentarum area, West Kalimantan, Indonesia. Journal of Quaternary Science. 19 (7): 637-655.

Anshari G, Kershaw AP, van der Kaars S. 2001. A Late Pleistocene and Holocene pollen and charcoal record from peat swamp forest, Lake Sentarum Wildlife Reserve, West Kalimantan, Indonesia. Palaeogeography, Palaeoclimatology, Palaeoecology. 171: 213-228. 
Azanza RV, Siringan FP, San Diego-McGlone ML, Yñiguez AT, Macalalad NH, Zamora PB, Agustin MB, Matsuoka K. 2004. Horizontal dinoflagellate cyst distribution, sediment characteristics and benthic flux in Manila Bay, Philippines. Phycological Research. 52: 376-386.

Bajarias F. 1995. Dynamics of Pyrodinium red tide in the coastal waters of Masinloc, Zambales, Philippines. In International seminar on marine fisheries environment. Wuthisiu, P., Otawa, N. (eds.), pp. 139-147, EMDEC and JICA, Rayong.

Baum A, Rixen T. 2014. Dissolved inorganic nitrogen and phosphate in the human affected blackwater river Siak, central Sumatra, Indonesia. Asian Journal of Water, Environment and Pollution. 11(1): 13-24.

Boely T, Linting M, Cremoux JL, Petit D, Potier M, Nurhakim S, Sujianto. 1991. Estimation of the abundance of pelagic fish in the central part of the Java Sea (Indonesia). Journal of Marine Fishery Research Institute. 58: 107.

Caratini C, Tissot C. 1988. Paleogeographical evolution of the Mahakam Delta in Kalimantan, Indonesia during the Quaternary and Late Pliocene. Review of Palaeobotany and Palynology. 55: 217228.

Couwenberg, J, Dommain, R, Joosten, H. 2010. Greenhouse gas fluxes fromtropical peatlands in. South-East Asia. Global Change Biology. 16: 1715-1732. doi: 10.1111/j.13652486.2009.02016.

Dommain R, Couwenberga J, Glaser PH, Suryadiputra INN. 2014. Carbon storage and release in Indonesian peatlands since the last deglaciation. Quaternary Science Reviews. 97: 1-32.

Durand JR, Petit D. 1995. The Java Sea environment. in: BIODYNEX: Biology, Dynamics, Exploitation of the small pelagic fishes in the Java Sea. Potier M and Nurhakim S (eds.), Java Sea Pelagic Fishery Assessment Project. 32: 65-71.

Edwards LE, Andrle VAS. 1992. Distribution of selected dinoflagellate cysts in modern marine sediments. In: Head MJ. and Wrenn JH (eds.), Neogene and Quaternary Dinoflagellate Cysts and Acritarchs, p.259-288; American Association of Stratigraphic Palynologists Foundation, Dallas, U.S.A.

Emery KO, Uchupi E, Sunderland J, Uktolseja HL, Young EM. 1972. Geologlcal structure and some water characteristics of the Java Sea and adjacent continental shell. United Nations ECAFE, CCOP Technical Bulletin. 6: 197-223.

Erdtman G. 1960. The acetolysis method. Svensk Botanisk Tidskrift. 54: 561-564.

Faegri K, Iversen J. 1975. Textbook of Pollen Analysis, 4th Ed. Chichester, J. Wiley and Sons Ltd.

Fang G, Susanto RD, Wirasantosa S. 2010. Volume, heat and freshwater transports from the South China Sea to Indonesian seas in the boreal winter of 2007-2008. Journal of Geophysical Research. 115, C12020, doi:10.1029/2010JC006225.

Fensome RA, Williams GL. 2004. The Lentin and Williams index of fossil dinoflagellates. AASP Foundation Contributions Series. 42.

Fischer G. 1991. Stable carbon isotope ratios of plankton carbon and sinking organic matter from the Atlantic sector of the Southern Ocean. Marine Chemistry. 35: 581-596.

Fukuyo Y. 2007. Vertical Plankton and Benthos Research, distribution of Pyrodinium bahamense var. compressum (Dinophyceae) cysts in Ambon Bay and Hurun Bay, Indonesia. Plankton and benthos research. 2 (4): 163-174.

Furio EF, Matsuoka K, Mizushima K, Baula I, Chan KW, Puyong A, Srivilai D, Sidharta BR, Fukuyo Y. 2006. Assemblage and geographical distribution of dinoflagellate cysts in surface sediments of coastal waters of Sabah, Malaysia. Coastal Marine Science. 30 (1): 62-73. 
Furio EF, Azanza RV, Fukuyo Y, Matsuoka K. 2012. Review of geographical distribution of dinoflagellate cysts in Southeast Asian coasts. Coastal Marine Science. 35 (1): 20-33.

Ganssen G, Troelstra SR, Faber B, van der Kaars SA, Situmorang M. 1989. Late quaternary palaeoceanography of the Banda Sea, eastern Indonesian piston cores (Snellius-II Expedition, cruise G5). Netherlands Journal of Sea Research. 24 (4): 491-494.

Genia AN, Nugroho AS, Olugbenda JO. 2007. Introduction to Java See. Oceanography. Stavanger, University of Stavanger.

Geyh MA, Kudrass H-R. 1979. Sea-level changes during the late Pleistocene and Holocene in the Strait of Malacca. Nature. 278: 441-443.

Gingele FX, De Deckker P, Girault A, Guichard F. 2002. History of the South Java Current over the past 80 ka. Palaeogeography, Palaeoclimatology, Palaeoecology. 183: 247-260.

Gonzales CL. 1989. Pyrodinium blooms and paralytic shellfish poisoning in the Philippines. In Biology, epidemiology and management of Pyrodinium red tides. Hallegraeff G. M. and Maclean J.L. (eds.), pp. 39-48, Conference Proceedings 21 ICLARM.

Gonzales CL, Ordonez JA, Maala AM. 1989. Red tide: the Philippine experience. In Red Tides. Okaichi T, Anderson DM, Nemoto T. (eds), pp. 45-48, Elsevier, New York.

Griffiths ML, Drysdale RN, Gagan MK, Zhao JX, Ayliffe LK, Hellstrom JC, Hantoro WS, Frisia S, Feng YX, Cartwright I, Pierre ES, Fischer MJ, Suwargadi BW. 2009. Increasing Australian-Indonesian monsoon rainfall linked to early Holocene sea-level rise. Nature Geoscience. 2: 636-639. doi:10.1038/ngeo605.

Grimm EC. 1987. CONISS: A FORTRAN 77 program for stratigraphically constrained cluster analysis by method of incrimination sum of squares. Computers and Geosciences. 13 (1): 13-35.

Hanebuth T, Stattegger K, Grootes PM. 2000. Rapid flooding of the Sunda Shelf: a Late-Glacial sea-level record. Science. 288: 1033-1035.

He Zh, Feng M, Wang M, Slawinski D. 2015. Contribution of the Karimata Strait transport to the Indonesian Throughflow as seen from a data assimilation model. Continental Shelf Research. 92: 16-22.

Head MJ, Westphal H. 1999. Palynology and paleoenvironments of a Pliocene carbonate platform: the Clino Core, Bahamas. Journal of Paleontology. 73 (1): 1-25.

Hessler I, Young M, Holzwarth U, Mohtadi M, Lückge A, Behling H. 2013. Imprint of eastern Indian Ocean surface oceanography on modern organic-walled dinoflagellate cyst assemblages Marine Micropaleontology. 101: 89-105.

Hill MO, Gauch HG. 1980. Detrended Correspondence Analysis: An Improved Ordination Technique. Vegetatio. 42: 47-58.

Horton BP, Gibbard PL, Milne GM, Morley RJ, Purintavaragul C, Stargardt JM. 2005. Holocene sea levels and palaeoenvironments, Malay-Thai Peninsula, Southeast Asia. The Holocene. 15 (8), 1199-1213. URL:http://dx.doi.org/10.1191/0959683605hl891rp

Horton BP, Zong Y, Hillier C, Engelhart S. 2007. Diatoms from Indonesian mangroves and their suitability as sea-level indicators for tropical environments. Marine Micropaleontology. 63: 155-168.

Jongman RHG, ter Braak CJF, van Tongeren OFR. (Eds) 1987. Data analysis in community and landscape ecology. Pudoc Wageningen, The Nederlands.

Kawamura H. 2004. Dinoflagellate cyst distribution along a shelf to slope transect of an oligotrophic tropical sea (Sunda Shelf, South China Sea). Phycological Research. 52: 355-375.

Kokinos JP, Eglinton TI, Goni MA, Boon JJ, Martoglio PA, Anderson DM. 1998. Characterization of a highly resistant biomacromolecular material in the cell wall of a marine dinoflagellate resting cyst. Organic Geochemistry. 28 (5): 265-288. 
Limoges A, Londeix L, de Vernal A. 2013. Organic-walled dinoflagellate cyst distribution in the Gulf of Mexico. Marine Micropaleontology. 102: 51-68.

Lirdwitayaprasit T. 1997. Distribution of dinoflagellate cysts in the surface sediment of the South China Sea, Area I: Gulf of Thailand and East Coast of Peninsular Malaysia. In Proceedings of the first technical seminar on marine fishery resources survey in the South China Sea. pp. 294-309. Training Department, SEAFDEC.

Lirdwitayaprasit T. 1998. Distribution of dinoflagellate cysts in the surface sediment of the South China Sea, Area II: Sabah, Sarawak and Brunei Darussalam waters. In: Proceedings of the second technical seminar on marine fishery resources survey in the South China Sea. pp. 310-322. Training Department, SEAFDEC.

Liu WT, Xie X. 1999. Space-based observations of the seasonal changes od South Asian monsoon and oceanic responses. Geophysical Research Letters. 26 (10): 1473-1476.

Manly BFJ. 1992. The Design and Analysis of Research Studies. Cambridge, Cambridge University Press.

Marret F, Mudie P, Aksu A, Hiscott RN. 2009. A Holocene dinocyst record of a two-step transformation of the Neoeuxinian brackish water lake into the Black Sea. Quaternary International. 197: 72-86.

Marret F, Zonneveld KAF. 2003. Atlas of modern organic-walled dinoflagellate cyst distribution. Review of Palaeobotany and Palynology. 125: 1-200.

Matsuoka K, Fukuyo Y, Praseno DP, Adnan Q, Kodama M. 1999. Dinoflagellate Cysts in Surface Sediments of Jakarta Bay, off Ujung Pandang and Larantuka of Flores Islands, Indonesia with Special Reference of Pyrodinium bahamense. Bulletin of the Faculty of Fisheries, Nagasaki University. 80: 49-54.

Moore PD, Webb JA, Collinson ME. 1999. Pollen analysis. Blackwell, Oxford.

Morley RJ. 1981. Development and Vegetation Dynamics of a Lowland Ombogenous Peat Swamp in Kalimantan Tengah, Indonesia. Journal of Biogeography. 8: 383-404.

Mortlock RA, Froelich PN. 1989. A simple method for the rapid determination of biogenic opal in pelagic marine sediments. Deep Sea Research Part A. Oceanographic Research Papers. 36 (9): 1415-1426.

Murgese DS, De Deckker P, Spooner MI, Young M. 2008. A 35,000 year record of changes in the eastern Indian Ocean offshore Sumatra. Palaeogeography, Palaeoclimatology, Palaeoecology. 265: 195-213.

Pillar VD. 1999. How sharp are classification? Ecological Society of America Ecology. 80 (8): 2508-2516.

Pillar VD, Orlóci L. 1996. On randomization testing in vegetation science: Multifactor comparisons of relevé groups. Journal of Vegetation Science. 7: 585-592.

Poliakova A, Rixen T, Jennerjahn T, Behling H. 2014. Annual High Resolution Pollen and Spore Sedimentation Record off SW Java in the Indian Ocean. Marine Micropalaeontology. 111: 90-99.

Poliakova A, Behling H. 2015. Fossil pollen and fern spores recorded in the late Holocene marine sediments from the Java Sea. Submitted to Quaternary International. doi:10.1016/j.quaint.2015.06.046.

Rao CR. 1964. The use and interpretation of principal component analysis in applied research. Sankhya: The Indian Journal of Statistics, Series A. 26: 329-358.

Reeves JM, Barrows TT, Cohen TJ, Kiem AS, Bostock HC, Fitzsimmons KE, Jansen JD, Kemph J, Krause C, Petherick L, Phipps SJ, OZ-INTIMATE Members. 2013a. Climate variability over the last 
35,000 years recorded in marine and terrestrial archives in the Australian region: an OZ-INTIMATE compilation. Quaternary Science Reviews. 74: 21-34.

Reeves JM, Bostock HC, Ayliffe LK, Barrows TT, De Deckker P, Devriendt LS, Dunbar GB, Drysdale RN, Fitzsimmons KE, Gagan MK, Griffiths ML, Haberle SG, Jansen JD, Krause C, Lewis S, McGregor HV, Mooney SD, Moss P, Nanson GC, Purcell A, van der Kaars S. 2013b. Palaeoenvironmental change in tropical Australasia over the last 30,000 years-A synthesis by the OZINTIMATE group Palaeoenvironmental change in tropical Australasia over the last 30,000 years-A synthesis by the OZ-INTIMATE group. Quaternary Science Reviews. 74: 21-34.

Reotita JM, Siringan FP, Sta, MYY, Azanza RV, David CP. 2008. Distribution and possible transport of the dinoflagellate cysts: Roles in Harmful Algal Bloom Dynamics. Terminal Report Project 4a under the Research Program entitled "Development and application of predicting, controlling and mitigating (PCM) techniques for Hamrful Algal Blooms (HABs) in selected mariculture sites in the Philippines". University of the Philippines, Diliman, Quezon City.

Rijksen HD, Meijaard E. 1999. Our vanishing relative: the status of wild orang-utans at the close of the twentieth century, Springer.

Ropelewski CF, Halpert MS. 1987. Global and regional scale precipitation patterns associated with El Niňo/Southern Oscillation. Monthly Weather Reviews. 115: 1606-1626.

Schulz HD, Zabel M, (Eds) 2000. Marine geochemistry. Springer-Verlag.

Scoffin TP, Le Tissier MDA. 1998. Late Holocene sea level and reef-flat progradation, Phuket, South Thailand. Coral Reefs. 17: 273-276.

Šmilauer P, Lepš J. 2014. Multivariate Analysis of Ecological Data using Canoco 5. Cambridge, Cambridge University Press.

Southon J, Kashgarian M, Fontugne M, Metivier B, Yim WWS. 2002. Marine reservoir corrections for the Indian Ocean and Southeast Asia. Radiocarbon. 44 (1): 167-80.

Stockmarr J. 1971. Tablets with spores used in absolute pollen analysis. Pollen et Spores, 13: 615-621.

Stuijts I. 1993. Late Pleistocene and Holocene vegetation of West Java, Indonesia. Modern Quaternary Research in South-East Asia 12, A. A. Balkema Publishers, Rotterdam.

Stuiver M, Polach H. 1977. Reporting of 14C data. Radiocarbon. 19: 355-363.

Stuiver M, Reimer PJ. 1986. A computer program for radiocarbon age calibration. Radiocarbon. 28: 1022-1030.

Stuiver M, Reimer PJ. 1993. Extended 14C database and revised CALIB radiocarbon calibration program, Radiocarbon. 35: 215-230.

Stuiver M, Reimer PJ, Bard E, Beck JW, Burr GS, Hughen KA, Kromer B, McCormac FG, v. d. Plicht J, Spurk M. 1998. INTCAL98 Radiocarbon age calibration 24,000 - 0 cal BP. Radiocarbon. 40: 1041-1083.

Stuiver M, Reimer PJ, Reimer RW. 2005. CALIB 5.0. Program and documentation. http://calib.qub.ac.uk/calib

Suryantini IA, Kuncoro IA, Saputri D, Helfinalis F. 2011. Marine Sediment Characteristics at Karimun, Java Sea, Based on Stratigraphic Profile Analysis, Total Suspended Solid (TSS) and Grain Size Analysis (Granulometry). Jurnal IImu dan Teknologi Kelautan Tropis. 3 (1): 26-51.

Ter Braak CP, Šmilauer P. 2002. CANOCO Reference manual and CanoDraw for Windows User's Guide: Software for Canonical Community Ordination. Microcomputer Power Editors, Ithaka NY, USA.

Tija HD. 1996. Sea-level changes in the tectonically stable Malay-Thai Peninsula. Quaternary International. 31: 95-101. 
Van Soelen EE, Lammertsma El, Cremer H, Donders TH, Sangiorgi F, Brooks GR, Larson RA, Sinninghe Damsté JS, Wagner-Cremer F, Reichart GJ. 2010. Late Holocene sea-level rise in Tampa Bay: integrated reconstruction using biomarkers, pollen, organic-walled dinoflagellate cysts, and diatoms. Estuarine, Coastal and Shelf Science. 86: 216-224.

Versteegh GJM, Zonneveld KAF. 2002. Use of selective degradation to separate preservation from productivity. Geology, 30: 615-618.

Wall D, Dale B, Lohmann GP, Smith WK. 1977. The environmental and climatic distribution of dinoflagellate cysts in modern marine sediments from regions in the North and South Atlantic Oceans and adjacent seas. Marine Micropaleontology. 2: 121-200.

Weiss D, Shotyk W, Rieley J, Page S, Gloor M, Reese S, Martinez-Cortizas A. 2002. The geochemistry of major and selected trace elements in a forested peat bog, Kalimantan, SE Asia, and its implications for past atmospheric dust deposition. Geochimica et Cosmochimia Acta. 66: 23072323

Wiadnyana NN, Sediadi A, Sidabutar T, Yusuf SA. 1994. Bloom of the dinoflagellate, Pyrodinium bahamense var. compressum, in Kao Bay, North Moluccas. In: Proceeding of the IOC/WESTPAC 3rd international science symposium. pp. 104-112, Bali, Indonesia.

Woodroffe CD, McLean R. 1990. Microatolls and recent sea-level change on coral atolls. Nature 344, 531-534.

Woodroffe SA, Horton BP. 2005. Late and post glacial sea-level changes of the Indo-Pacific: A review. Journal of Asian Earth Science. 25: 29-43.

Wyrtki K. 1961. Physical Oceanography of the Southeast Asian Water, Naga Report V.2. Scripps Institute of Oceanography, University of California.

Zonneveld KAF. 1997. Dinoflagellate cyst distribution in surface sediments from the Arabian Sea (northwestern Indian Ocean) in relation to temperature and salinity gradients in the upper water column. Deep Sea Research Part II. 44 (6-7): 1411-1443.

Zonneveld KAF, Bockelmann F, Holzwarth U. 2007. Selective aerobic degradation of organicwalled dinoflagellates as tool to quantify past net primary production and bottom water oxygen concentrations. Marine Geology. 237: 109-126.

Zonneveld KAF, Brummer G-JA. 2000. (Palaeo-)ecological significance, transport and preservation of organic-walled dinoflagellate cysts in the Somali Basin, NW Arabian Sea. Deep Sea Research Part II. 47: 2229-2256.

Zonneveld KAF, Chen L, Möbius J, Mahmoud M. 2009. Environmental significance of dinoflagellate cysts from the proximal part of the Po-river discharge plume (off southern Italy, Eastern Mediterranean). Journal of Sea Research. 62: 189-213.

Zonneveld KAF, Marret F, Versteegh GJM, Bogus K, Bonnet S, Bouimetarhan I, Crouch E, de Vernal A, Elshanawany R, Edwards L, Esper O, Forke S, Grøsfjeld K, Henry M, Holzwarth U, Kielt J-F, Kim S-Y, Ladouceur S, Ledu D, Chen L, Limoges A, Londeix L, Lu S-H, Mahmoud MS, Marino G, Matsouka K, Matthiessen J, Mildenhal DC, Mudie P, Neil HL, Pospelova V, Qi Y, Radi T, Richerol T, Rochon A, Sangiorgi F, Solignac S, Turon JL, Verleye T, Wang Y, Wang Z, Young M. 2013. Atlas of modern dinoflagellate cyst distribution based on 2405 data points. Review of Palaeobotany and Palynology. 191: 1-197.

Zonneveld KAF, Pospelova V. 2015. A determination key for modern dinoflagellate cysts. Palynology. 1-23. http://dx.doi.org/10.1080/01916122.2014.990115. 


\section{CHAPTER 6}

Pollen and fern spores recorded in recent and late Holocene marine sediments from the Indian Ocean and Java Sea in Indonesia

Anastasia Poliakova and Hermann Behling

(e) Albrecht-von-Haller-Institute for Plant Sciences, Department of Palynology and Climate Dynamics, Georg-August-Universität-Göttingen, Untere Karspüle 2, Göttingen, D-37073 Germany;

Quaternary International: 392 (2016) 251-314

http://dx.doi.org/10.1016/j.quaint.2015.06.046

Keywords: pollen and spores diversity; marine sediments; tropical vegetation; late Holocene; Java Sea; Indian Ocean 


\begin{abstract}
Fossil pollen and spore diversity in marine sediment cores from the coasts off SW Kalimantan and NE Java (Java Sea) as well as modern pollen assemblages collected off West Java in the SE Indian Ocean in a marine sediment trap are documented in this paper. In total, photographic images of 138 pollen and 41 spores including 14 pollen and 32 unidentified spore types are presented in morphological order. Illustrated pollen and spore taxa list may help pollen and spore identification of future palynological investigations focused on the reconstruction of past vegetation, climate and environment dynamics in SE Asia.
\end{abstract}

\title{
6.1. Introduction
}

With the development of palynology as an applied method in micropalaeontology, palaeoecology and palaeoclimatology and an increased interest in the vegetation-pollen deposition relationship, a number of continental and subcontinental pollen atlases (e.g. list from Hooghiemstra and van Geel, 1998) and databases have been established since the late 1970's (Rowe, 2006): the North American Pollen Database (Grimm, 2000), incorporating the datasets from Canada (Gajewski, 2005), Alaska (Anderson and Brubaker, 1986), eastern North America (Webb and McAndrews, 1976) and the southwestern United States (Davis, 1995); the European Pollen Database (Cheddadi, 2002), PalDat - a palynological dataset based in Austria (Buchner and Weber, 2000), Cambridge University Palynological Online Database (QPG, 2008) and a database for the Northwest European Pollen Flora (Punt et. al., 2003); the Africa Pollen Database (Lézine, 2005); the image collections of Latin American Pollen Database (Marchant et al., 2002) and of the Neotropical Pollen Database (Bush and Weng, 2007).

For Southeast (SE) Asia, only a few sources of the information on pollen are available, such as the Australasian Pollen and Spore Atlas (APSA, 2007), an online accessible database that contains a large collection of pollen and spores images (details on about 15,000 species) and morphological descriptions from the Australasian region. The database deals not only with Australia itself, but also provides information on pollen from tropical India, tropical China, New Guinea, New Zealand, the Hawaiian Islands, Oceania and the Southeast Asia (SE), including the continental (Malay Archipelago) and maritime subregions. The last subregion refers to the vast group of islands located between mainland SE Asia and Australia (Rowe, 2006). Collection of Indonesian fossil and modern pollen photos of Department of Palynology and Climate Dynamics is being developed recently and is also available (Albrecht-von-Haller-Institute for Plant Sciences, the University of Göttingen, Germany: http://www.gdvh.uni-goettingen.de/).

Additionally, a specific GIS atlas provides data on the fossil and modern records of Ficus and related species of island SE Asia, Australasia, and the Western Pacific (Jago and Boyd, 2003). The pollen atlas of Malaysia (Kiew and Muid, 1991) describes pollen of 95 species in 84 genera and 43 families with 
regard of beekeeping. For each species a photograph of the whole plant, the flower, and pollen grain is presented, as well as provided information on pollen size/colour, plant habit (crop, weed or forest taxa) and distribution.

Furthermore, a modern palynoflora of the Philippines (Jagudilla-Bulalacao, 1997) is published. The atlas contains light and SEM microphotographs as well as the morphological key and descriptions of 45 species related to 264 genera and 63 families.

Several papers on pollen morphology are available for Taiwan (Huang, 1972, 1981) and tropical Asia in general (Guinet, 1962; Tilak, 1989). For Malaysian Borneo a paper on the pollen diversity of the Kelabit Highlands (Jones, 2014) presenting microphotographs from pollen grains of about 200 species with a morphological key has been recently published in addition to older pollen studies by Anderson and Muller (1975) on a Holocene peat near Marudi (Sarawak) and a Miocene coal near Berakas (Brunei). Additionally, publications on pollen morphology of selected plant families are available, e.g. by Adam and Wilcock (1999) on Bornean Nepenthes, and by Sofiyanti and Yen (2012), who described pollen grains of Malaysian and Indonesian Rafflesia.

Specifically on pollen diversity in Indonesia, since the early 1990s are provided only two publications, a study on the Late Pleistocene and Holocene vegetation of West Java (Stuijts, 1993) and a pollen morphology overview of the main taxa from the SE Asian archipelago (Van der Kaars, 1993). Concerning the pollen and spores in marine sediments in the Indonesian Archipelago, available amount of information is still very limited. Marine palynology started to develop in the region only in recent decades. The first work on the marine palynomorphs in the region was the study on the palynological residues from surface sediments in the Banda Sea (Van Waveren, 1989) where 'a series of 27 palynomorph types are described and informally categorized', although the paper does not contain any analysis of palaeomorphs. First pollen analytical works for the Indonesian region were published at the beginning of 1990s (Van der Kaars, 1991; Barmawidjaja et al., 1993) and indicated the potential of marine palynology in the reconstruction of the vegetation of this region. A number of papers were published for the Banda Sea (e.g. Van der Kaars et al., 2000; Ahmad et al., 1995; Spooner et al., 2005), Celebes Sea (van der Kaars, 1991), Sulu Sea (Beaufort et al., 2003), Molucca Sea (Barmawidjaja et al., 1993), Mahakam Delta, Kalimantan (Caratini and Tissot, 1988), Makassar Strait (Yulianto, 2004; Visser et al., 2004), eastern Indian Ocean (Wang, et al., 1999) and southern Indian Ocean (Poliakova et al., 2014), off Sumatra (van der Kaars et al., 2010, 2012).

In this paper, we would like to contribute in filling an important knowledge gap with pollen diversity in the region. We summarize our knowledge gained from the work on marine sediments from the Java Sea and SE Indian Ocean with the aims (1) to provide a documentation of modern and fossil pollen and spores recorded in the last $\sim 3500 \mathrm{yr}$ and (2) to compare pollen diversity indicating 
different vegetation types described for South Kalimantan and East Java. This work will be relevant to research involving pollen and spore identification and/or focused on the fossil pollen diversity, it may also help in future palynological investigations focused on the reconstruction of past vegetation, climate and environment dynamics in Indonesia as well as in SE Asia in general.

\subsection{Modern vegetation as a source for pollen and spore in the Java Sea}

Most of pollen and spores found in the marine sediment deposits off Jelai, Pembuang and Solo rivers were transported by wind and river systems and have their main source from the vegetation of South Kalimantan and East Java, respectively. Modern vegetation is briefly described below. However, it needs to be considered that a certain amount of pollen and spores can also be transported over longer distance by wind and in particular by the oceanic circulation (for details see Poliakova et al., 2014).

\subsubsection{East Java}

River Solo is the longest river in Java (ca. $600 \mathrm{~km}$ ) with the broad catchment area $\left(15,400 \mathrm{~km}^{2}\right.$, Whitten, 1996) transporting great amount of the sediments to the Java See. The river has two sources in high mountains, the volcano of Mount Lawu (3265 m elevation) and the Kidul Highlands (ca. $500 \mathrm{~m}$ ), as well as the early tributary Dengkeng River which has its source in Mount Merapi (2800 m, Whitten et al., 1996, http://wetlands.or.id/).

Modern vegetation of the drainage area is mainly represented by the secondary lowland forest, some freshwater swamp forests, submontane (1000-1500 m), lower montane (1800 and $2400 \mathrm{~m})$, and upper montane (2400-3000 m) forest (Fig. 1) (e.g. Whitten et al., 1996; MacKinnon et al., 1997). Mangroves are represented by only small numbers of individual Sonneratia and Rhizophora trees. Lowland forest along the coasts of the River Solo is virtually absent; most of its area has been turned into agricultural/aquacultural landscapes. Some remains of the secondary lowland vegetation are characterised by presence of Acalypha (Euphorbiaceae), Ficus (Moraceae), Macaranga, Mallotus (Euphorbiaceae), Trema (Cannabaceae), Pandanus (Pandanaceae) and other pioneer taxa (e.g. Backer et al., 1965; Van Steenis, 1984; Whitmore, 1984).

Submontane forest in the East and Central Java is dominated by Castanopsis, Lithocarpus and Quercus (Fagaceae). Mountain forest is characterised by relatively strong vertical zonation and represented mainly by Engelhardia (Juglandaceae), Podocarpaceae (Dacrycarpus, Podocarpus), Ericaceae, Myrica (Myricaceae), Myrsinaceae, and Weinmannia (Cunoniaceae) (Van Steenis, 1984; 
Kaars and Dam, 1995). Mountain vegetation is regularly suffering from fire, and forest gives way to grasslands (Stuijts, 1993).

\subsubsection{South Kalimantan}

In Borneo, the Jelai River (ca. 100 km long) separates the Indonesian provinces of Central and South Kalimantan and has the source in the SE slopes of the Schwaner Mountain Range (average height $500 \mathrm{~m}$; the highest point - Mt. Bukit Raya, $2278 \mathrm{~m}$ ) and is draining mainly through open areas with shrubs and grasslands particularly at the Central Kalimantan side (http://wetlands.or.id/). At this eastern bank of the Jelai River, a broad and more or less uninterrupted belt of riparian forest occurs (Fig. 1). On the western bank, there is a mosaic of forest and clearings. Although, the main water catchment area for the River Jelai is a peat swamp forest on Gambut and Mendawai land systems, 'the only remaining peat swamp forest occur at the south part of West Kalimantan' (http://wetlands.or.id/) with Anacardiaceae, diverse Dipterocarpaceae, Elaeocarpus, Engelhardia, Euphorbiaceae, Macaranga and Mallotus.

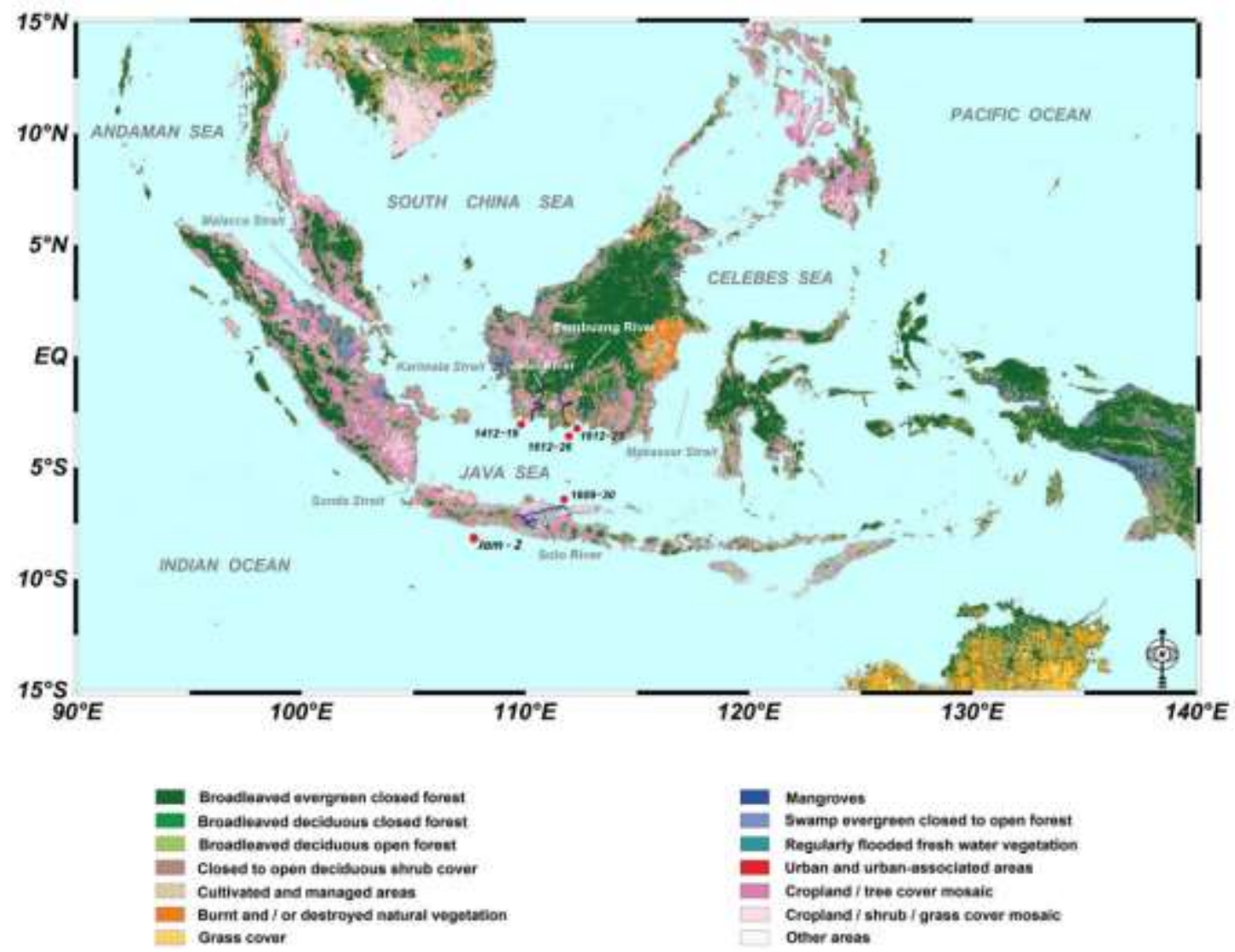

Figure 1. Schematic map of the study area with distribution patterns of main vegetation types. Marine sediment cores and a sediment trap are shown with red dots. Data on the vegetation 
distribution are derived from OSGeo website (http://geonetwork-opensource.org) and partly from Stibig et al. (2002).

The River Pembuang (ca. $300 \mathrm{~km}$ long) has its source near the Bikit Tikung (1175 m elevation) in the Schwaner Mountain Range. Mangroves in the area of the mouth of River Pembuang are composed of Avicennia (Avicenniaceae), Nypa (Arecaceae), Rhizophoraceae, Sonneratiaceae, and other taxa. The eastern side of the river contains dense lowland forest down to Sembulu (Belajau) lakes (Rijksen and Meijaard, 1999).

The lowland rainforest of South Kalimantan Borneo has a great diversity (e.g. Whitmore, 1984; Jacobs, 1988; Whitten et al., 1987a, 1987b, Rubeli, 1986; MacKinnon, 1986, 1992; MacKinnon et al., 1997); there are as many as 240 different species of trees growing within a hectare (Kartawinata et al., 1981; Ashton, 1989). Main types of lowland rainforest of southern Kalimantan are dipterocarp forest, heath forest (in Indonesian: Kerangas), ironwood forests predominating by Eusideroxylon zageri, or Belian, a common and commercially valuable species, as well as forests on limestones and ultrabasic rocks. The general characteristics of these forests are canopies 24-36 m high with emergents reaching up to $65 \mathrm{~m}$. Dipterocarpaceae is a dominant family in the emergent stratum. In the richest forests, up to $80 \%$ of the emergent trees are dipterocarps: Dipterocarpus, Dryobalanops, Shorea. Hopea and Vatica together with species from Berseraceae and Sapotaceae families are usually found in the main canopy as well.

A third layer occurs below the canopy of shade-tolerant species, adorned with lianas, orchids, and epiphytic ferns. This layer includes many species from the Euphorbiaceae, Rubiaceae, Annonaceae, Lauraceae, and Myristicaceae families. In some cases Euphorbiaceae is more common than dipterocarps, being the second most common family in Kalimantan (MacKinnon et al., 1997).

In submontane and montane areas of Borneo, Whitmore (1984) described five altitudinal floristic zones. These are already described lowland dipterocarp zone (less than $300 \mathrm{~m}$ ), the hill dipterocarp zone $(300-800 \mathrm{~m})$, the upper dipterocarp zone $(800-1200 \mathrm{~m})$, the oak-chestnut zone with Fagaceae and Lauraceae predominant (1200-1500m), and the montane ericaceous zone (higher than $1500 \mathrm{~m}$ ). Upper montane forests share many species and features of the structure and appearance with heath forests (Eugenia, Rhododendron, Vaccinium), yet none of the heath forest dipterocarps expends above $1,500 \mathrm{~m}$. Only few plants span the complete altitudinal range from lowlands to upper montane forest, e.g. Dacrydium (Whitmore, 1984; MacKinnon et al., 1997). The highest altitudes of South Kalimantan bare closed-canopy scrubs.

\subsection{Material and methods}

\subsubsection{Sediment material}


This work was based on the modern pollen and spore material collected with the help of an ocean sediment trap, as well as on the fossil material available from the four short marine sediment cores (Fig. 1) that were obtained from four shallow water bore holes drilled in the northern and southeastern parts of the Java Sea. Core 1412-19 (S3 15' 28.8"; E110 38' 59.399"; length $91.5 \mathrm{~cm}$ ) was taken from the mouth of the Jelai River, SW Kalimantan. Cores 1612-23 (S3 ${ }^{\circ} 35^{\prime} 21.84 "$; E112 ${ }^{\circ} 44^{\prime}$ 13.56"; length $134 \mathrm{~cm}$ ) and 1612-26 (S3 47' 39.48"; E112 34' 6.96"; length $100 \mathrm{~cm}$ ) were retrieved off the Pembuang River plume, South Kalimantan. Core 1609-30 (S6²9' 49.729"; E112²8' 31.328"; length $96 \mathrm{~cm}$ ) was recovered from the mouth of the River Solo, East Java. Age schemes are given in

Fig. 2.

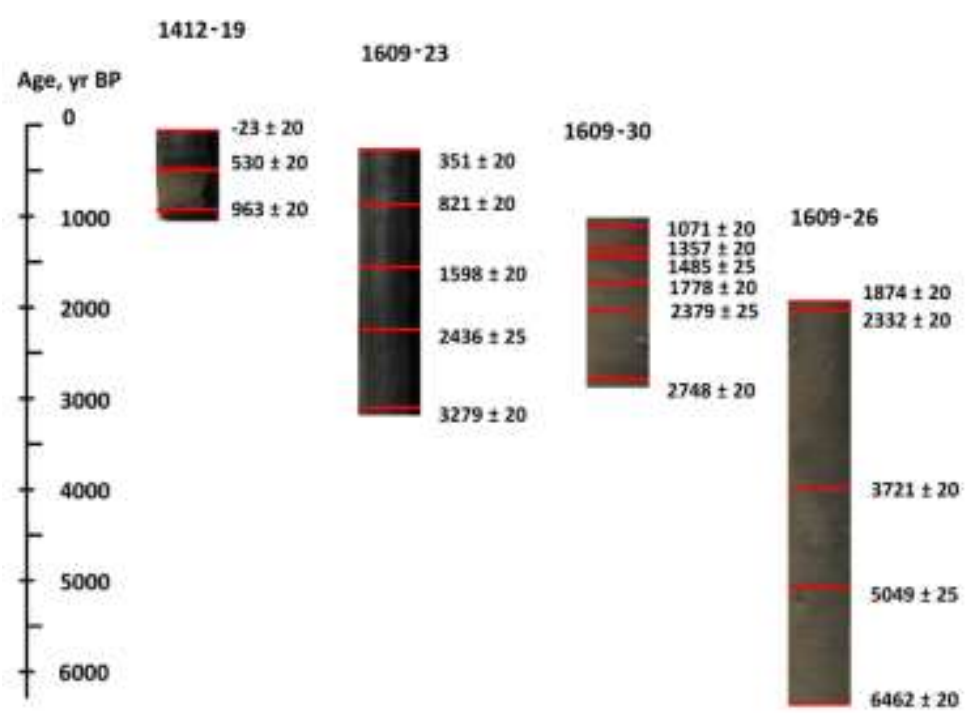

Figure 2. Age schemes of the marine sediment cores used for the present study. Radiocarbon dating (Stuiver and Polach, 1977) and calibration (CALIB 7, marine 13: Stuiver and Reimer, 1993) considered a reservoir age of 90 yrs (Southon et al., 2002).

Additionally, modern pollen and spores from the samples collected with sediment trap JAM-2 (Honjo and Doherty, 1988) (Fig. 1) were studied. Sediment trap had been installed in the SE Indian Ocean (S $\left.08^{\circ} 17^{\prime} 30^{\prime \prime} ; \mathrm{E} 108^{\circ} 02^{\prime} 00^{\prime \prime}\right)$ at $2200 \mathrm{~m}$ water depth and sampled between December 2001 and November 2002 about $830 \mathrm{~m}$ above the seafloor. The sampling interval of the trap was 16 days (Poliakova et al., 2014).

\subsubsection{Marine sediments and sample preparation}

For pollen and spore analysis, per sample $3 \mathrm{~g}$ of sediment was taken from the marine cores. The samples were treated following the standard palynological technique as is described by Faegri and Iversen (1975). First, the samples were filtered using a sieve with a mesh size of $150 \mu \mathrm{m}$ to remove the larger fraction. Cold hydrochloric acid $(\mathrm{HCl} 10 \%)$ was added for the removal of carbonate in amounts depending on the intensity of the reaction. Siliceous component of the samples was dissolved by adding of hydrofluoric acid (HF 72\%). Afterwards, the staining processes known in palynology as the acetolysis (Erdtman, 1952, 1969), was applied. To avoid the dangerous and highly 
exothermic reaction of the acetolysis mixture with water, dehydration with acetic acid $\left(\mathrm{CH}_{3} \mathrm{COOH}\right)$ was applied. At the next step, a 9:1 mixture of acetic anhydride $\left[\left(\mathrm{CH}_{3} \mathrm{CO}\right)_{2} \mathrm{O} 20 \%\right.$ ] and concentrated sulphuric acid $\left(\mathrm{H}_{2} \mathrm{SO}_{4} 90 \%\right)$ was added and the samples were kept for 10 minutes in the water bath (ca. $\left.90^{\circ} \mathrm{C}\right)$. To remove small organic particles $(<10 \mu \mathrm{m})$, the samples were sieved at a nylon filter at the final stage.

\subsubsection{Microscopic photo-documentation}

For pollen slides preparation glycerine gelatine was used. The photo documentation was done with the light microscope (Zeiss Axiostar Plus) and ocular magnifications between x200 and x1000 $\mu \mathrm{m}$ dependent on the size of objects. Microphotographs were taken, processed and scaled with the Leica DM 6000 B - CTR 6000B photomicroscope using Leica DFC 320 camera and Leica QWin software adjusted to auto-white-balance, continuous exposure measurement and increased contrast settings. Each pollen and spore type, where it was possible to obtain images, was photographed from both equatorial and polar view, with different focus, from high to low.

\subsubsection{Pollen and spore determination and nomenclature}

Taxonomy of pollen and spores is based on Moore and Webb (1978), Wang et al. (1995), JagudillaBulalacao (1997), Kodela (2000), Fujiki et al. (2005), Stevenson (2005), APG III (2009) and Mao et al., (2012). In each case, cross-checking with APSA (2007) and with our own reference collection for Indonesia and/or, if applicable, for other tropical areas was applied. Pollen was identified to the genera/species level when possible. In most cases, the family was indicated and if only, "indet." was added (e.g. Ericaceae indet.). If the definitive specification of the pollen/spore type was some doubtful, the sign "Cf." was used prior the name. The word "type" was used when including several other taxa, i.e. more than two different genera (e.g. Dacrycarpus type). If from the point of view of the morphology two identification possibilities were likely, both taxa was indicated (e.g. Moraceae/Urticaceae). Different morphological types within the same identification were distinguished by different numbers (e.g. Arecaceae indet., type 1 and Arecaceae indet., type 2). In cases when due to the bad preservation of the pollen/spore or because of some other objective reasons, further differentiation was not possible or ambiguous, the name 'indet. type' with number was used. Orhiza type was distinguished by careful morphological comparison with reference slides from modern Indonesian plants and measuring morphological parameters, i.e. both diameters of a grain, width of annulus and thickness of exine. Furthermore, the literature was used, i.e. Chaturvedi et al. (1998), Maloney (1990), Atahan et al. (2008). Photos of all identified pollen and spores as well 
as the original slides are available on request at the Department of Palynology and Climate Dynamics (Albrecht-von-Haller-Institute for Plant Sciences, University of Göttingen, Germany). Pollen terminology is followed Lang (1994) and Punt et al. (2007).

\subsection{Results and discussion}

In total, 124 pollen and 9 spore types were identified. Additionally, 14 undetermined pollen and 32 spore types were described. They are presented in 179 plates, following the morphological order (see Table). The analysed samples showed a good preservation of pollen and spores in the sediment material. Most of the pollen types belong to dicotyledonean angiosperms which is equal to $99(80 \%$, here and further percentage is given based on the total number of identified pollen types, excluding spores and unknown palynomorphs). The number of basal and monocotyledonean angiosperms is 16 (13\%). Gymnosperms are represented by 9 types (7\%).

Table of spore and pollen types according to their morphology (after Lang, 1994 with additions). Only identified types are included.

\begin{tabular}{|c|c|c|}
\hline Morphological type & Taxa & Plate \\
\hline \multirow[t]{2}{*}{ Monolete spores } & Davallia & 1 \\
\hline & Schizaea & 2 \\
\hline \multirow[t]{7}{*}{ Trilete spores } & Cf. Anthocerus & 19 \\
\hline & Cyathea & 20 \\
\hline & Dicksonia & 21 \\
\hline & Huperzia & 22 \\
\hline & Lycopodium & 23 \\
\hline & Ophioglossum & 24 \\
\hline & Selaginella & 25 \\
\hline \multirow{8}{*}{$\begin{array}{l}\text { Vesiculate, saccate } \\
\text { grains }\end{array}$} & Dacrycarpus type & 42 \\
\hline & Dacrydium type & 43 \\
\hline & Phyllocladus & 44 \\
\hline & Picea type & 45 \\
\hline & Pinus type 1 & 46 \\
\hline & Pinus type 2. Cf. P. sylvestris & 47 \\
\hline & Podocarpus & 48 \\
\hline & Tsuga type & 49 \\
\hline \multirow[t]{2}{*}{ Polyade grains } & Acacia & 50 \\
\hline & Albizia & 51 \\
\hline \multirow[t]{3}{*}{ Tetrade grains } & Annona & 52 \\
\hline & Ericaceae indet. & 53 \\
\hline & Mimosaceae indet. type & 54 \\
\hline Inaperturate grains & Agathis & 55 \\
\hline
\end{tabular}




\begin{tabular}{|c|c|c|}
\hline \multirow{12}{*}{ Monosulcate grains } & Areca & 56 \\
\hline & Arecaceae indet., type 1 & 57 \\
\hline & Arecaceae indet., type 2 & 58 \\
\hline & Arecaceae indet., type 3 & 59 \\
\hline & Arenga & 60 \\
\hline & Calamus & 61 \\
\hline & Caryota & 62 \\
\hline & Chloranthaceae indet. & 63 \\
\hline & Iridaceae/Liliaceae indet. & 64 \\
\hline & Nypa & 65 \\
\hline & Oncosperma & 66 \\
\hline & Pinanga & 67 \\
\hline Dicolporate grains & Cunoniaceae indet. & 68 \\
\hline \multirow[t]{7}{*}{ Tricolpate grains } & Acanthaceae indet. & 69 \\
\hline & Cf. Brassicaceae indet. type & 70 \\
\hline & Clematis & 71 \\
\hline & Durio & 72 \\
\hline & Oleaceae indet., type 1 & 73 \\
\hline & Plumbaginaceae indet. & 74 \\
\hline & Ranunculaceae indet. type & 75 \\
\hline \multirow[t]{3}{*}{ Heterocolpate grains } & Arceuthobium & 76 \\
\hline & Combretaceae/Melastomataceae indet., type 1 & 77 \\
\hline & Combretaceae/Melastomataceae indet., type 2 & 78 \\
\hline \multirow[t]{5}{*}{ Monoporate grains } & Oryza type & 79 \\
\hline & Pandanus & 80 \\
\hline & Poaceae indet. & 81 \\
\hline & Typha & 82 \\
\hline & Zea mais & 83 \\
\hline \multirow[t]{2}{*}{ Diporate grains } & Ficus & 84 \\
\hline & Trema & 85 \\
\hline \multirow[t]{12}{*}{ Triporate grains } & Allophylus, type 1 & 86 \\
\hline & Bignoniaceae indet., type 1 & 87 \\
\hline & Casuarina & 88 \\
\hline & Celtis & 89 \\
\hline & Cucurbitaceae indet. & 90 \\
\hline & Engelhardia & 91 \\
\hline & Fabaceae indet., type 1 & 92 \\
\hline & Myrica & 93 \\
\hline & Moraceae/Urticaceae indet. & 94 \\
\hline & Onagraceae indet. & 95 \\
\hline & Pometia & 96 \\
\hline & Sonneratia & 97 \\
\hline \multirow[t]{4}{*}{ Tetraporate grains } & Alnus, type 1 & 98 \\
\hline & Allophylus, type 2 & 99 \\
\hline & Dysoxylum & 100 \\
\hline & Garcinia & 101 \\
\hline
\end{tabular}




\begin{tabular}{|c|c|c|}
\hline \multirow{2}{*}{$\begin{array}{l}\text { 4-6-porate, } \\
\text { Stephanoporate } \\
\text { grains }\end{array}$} & \multirow{2}{*}{$\begin{array}{l}\text { Alnus, type } 2 \\
\text { Ulmus }\end{array}$} & \multirow{2}{*}{$\begin{array}{l}\frac{102}{103} \\
\end{array}$} \\
\hline & & \\
\hline 5-colpate & Quintinia & 104 \\
\hline 6-colpate grains & $\begin{array}{l}\text { Cf. Bignoniaceae indet., type 2/Cf. Lamiaceae } \\
\text { indet. }\end{array}$ & 105 \\
\hline \multirow[t]{11}{*}{ Periporate grains } & Altingia & 106 \\
\hline & Amaranthaceae indet. & 107 \\
\hline & Caryophyllaceae indet. & 108 \\
\hline & Cyperaceae indet. & 109 \\
\hline & Hibiscus & 110 \\
\hline & Juglandaceae indet. & 111 \\
\hline & Malvaceae indet., type 1 & 112 \\
\hline & Malvaceae indet., type 2 & 113 \\
\hline & Plantago & 114 \\
\hline & Thalictrum & 115 \\
\hline & Thymeliaceae indet. type & 116 \\
\hline \multirow[t]{31}{*}{ Tricolporate grains } & Acalypha & 117 \\
\hline & Aglaia & 118 \\
\hline & Ailanthus & 119 \\
\hline & Alchornea & 120 \\
\hline & Anacardiaceae indet. & 121 \\
\hline & Apiaceae indet. & 122 \\
\hline & Artemisia & 123 \\
\hline & Asteraceae indet., type 1 & 124 \\
\hline & Asteraceae indet., type 2 & 125 \\
\hline & Asteraceae indet., type 3 & 126 \\
\hline & Avicennia & 127 \\
\hline & Barringtonia & 128 \\
\hline & Bombacaceae indet. & 129 \\
\hline & Bruguiera & 130 \\
\hline & Castanopsis/Lithocarpus & 131 \\
\hline & Centauria & 132 \\
\hline & Clethra type & 133 \\
\hline & Dillenia & 134 \\
\hline & Dipterocarpaceae indet. & 135 \\
\hline & Elaeocarpus & 136 \\
\hline & Eucalyptus & 137 \\
\hline & Euphorbiaceae indet. & 138 \\
\hline & Fabaceae indet., type 2 & 139 \\
\hline & Hopea & 140 \\
\hline & Ilex & 141 \\
\hline & Ixora & 142 \\
\hline & Loranthaceae indet., type 1 & 143 \\
\hline & Loranthaceae indet., type 2 & 144 \\
\hline & Loranthaceae indet., type 3 & 145 \\
\hline & Lythraceae indet. & 146 \\
\hline & Macaranga/Mallotus & 147 \\
\hline
\end{tabular}




\begin{tabular}{|c|c|c|}
\hline & Malpighiaceae indet & 148 \\
\hline & Myrtaceae indet. & 149 \\
\hline & Polygonaceae indet. & 150 \\
\hline & Quercus & 151 \\
\hline & Rhizophora & 152 \\
\hline & Rosaceae indet. type & 153 \\
\hline & Rubiaceae indet. & 154 \\
\hline & Rutaceae indet. & 155 \\
\hline & Salix type & 156 \\
\hline & Sapindaceae indet. & 157 \\
\hline & Sapotaceae indet. & 158 \\
\hline & Symplocos & 159 \\
\hline & Verbenaceae indet. type & 160 \\
\hline & Vitaceae indet. type & 161 \\
\hline & Weinmannia & 162 \\
\hline 4-colporate grains & Meliaceae type & 163 \\
\hline & Oleaceae indet., type 2 & 164 \\
\hline Fenestrate grains & Asteraceae subfamily Cichorideae indet. & 165 \\
\hline
\end{tabular}

In terms of the size, the largest of pollen grains (larger than $50 \mu \mathrm{m}$ ) were recorded for Annona (Annonaceae, Appendix, Fig. 54), Malvaceae (Appendix, Fig. 114-115) including Hibiscus (Appendix, Fig. 112), Onagraceae (Appendix, Fig. 97), Picea type (Appendix, Fig. 47) and Tsuga type (Appendix, Fig. 49) (Pinaceae) some of Poaceae, e.g. Zea mays (Appendix, Fig. 85), while rather small grains (about $10 \mu \mathrm{m}$ and less) are represented by, for example, Aglaia (Meliaceae, Appendix, Fig. 120), Elaeocarpus (Elaeocarpaceae, Appendix, Fig. 137), some of Ficus (Moraceae, Appendix, Fig. 86) and Weinmannia (Cunnoniaceae, Appendix, Fig. 164).

Pollen diversity reflects regional vegetation sufficiently well; most of vegetation types could be inferred from pollen and spore assemblages both in Kalimantan and in Java. Among pollen, arboreal types estimate 99 ( $80 \%$ of all identified pollen types), while non-arboreal pollen types account 25 (20\%). Additionally, two tree ferns, i.e. Dicksonia (Appendix, Fig. 23) and Cyathea (Appendix,Fig. 22), as well as one spore type of mosses (Cf. Anthocerus, Appendix, Fig. 21) were represented. Wet lowland evergreen forest is indicated by 69 pollen types (57\% of all identified pollen types), while dry lowland forest is reflected by $4(3 \%) ; 7$ pollen types (6\%) are related to the submontane and/or lower montane forest and $11(9 \%)$ to the upper montane forest. Some 4-5 of pollen taxa (about 3\%) are related to the specifically tropical dipterocarp group, all found in samples off the Jelai and Pembuang rivers flowing through the large peat swamp areas in Kalimantan. Additionally, Engelhardia (Appendix, Fig. 93), Myricaceae (Appendix, Fig. 151), Ilex (Appendix, Fig. 142), Pandanus (Appendix, Fig. 82), and Durio (Appendix, Fig. 74) may point to this specific type of the vegetation. 
No evidences of dipterocarp forest were obtained for Java as this forest type is virtually absent from most of the island. Mangroves were reflected by 5 pollen types (4\%), all with the sufficient abundance. In the most modern samples, abrupt decrease in mangrove pollen abundance may point to the human activity induced destruction of mangrove belt, on Java especially. Aquatic vegetation was also reflected poorly, by Typha (Appendix, Fig. 84) and Cyperaceae indet. (Appendix, Fig. 111) only.

About the half of all pollen types were found both in the sediment core samples and in the samples from a sediment trap. The most abundant pollen types both for pollen trap and for sediment cores were those typical for the lowland rainforest, e.g. Elaeocarpus (Appendix, Fig. 137), Moraceae/Urticaceae (Appendix, Fig. 96), Euphorbiaceae (Appendix, Fig. 139) and submontane forest, e.g. Castanopsis/Lithocarpus (Appendix, Fig. 144), Quercus (Appendix, Fig. 153), Engelhardia (Appendix, Fig. 93), Myrica (Appendix, Fig. 93). High values (up to 60\%) of secondary vegetation taxa, e.g. Macaranga/Mallotus (Appendix, Fig. 149), Acalypha (Appendix, Fig. 119), Ficus (Appendix, Fig. 86), and Trema (Fig. 87) point to the wide occurrence of secondary forest and is supported by the modern pattern of lowland vegetation distribution (Appendix, Fig.1).

Montane forest is reflected by Podocarpus (Appendix, Fig. 50), Dacrycarpus (Appendix, Fig.44), Phyllocladus (Appendix, Fig. 46), Dacridium (Appendix, Fig. 43), Myrica, Engelhardia, and Ericaceae (Appendix, Fig. 55). For all vesiculate pollen long-distance transport cannot be excluded. Relatively frequent are Arecaceae pollen (Appendix, Fig. 58-64 and Fig. 68), particularly Arenga (Appendix, Fig. 62), in most of the modern samples. In the samples off Jelai River especially, Arecaceae pollen may indicate palm plantations. Additional indicator for a large formation of plantations in recent times could be the increased abundance of Eucalyptus (Appendix, Fig. 138) and occurrence of Pinus (Appendix, Fig. 48) pollen in sediment samples taken off East Java. Increased agricultural activity is reflected by a relative increase of large-grained Poaceae, e.g. Orhiza type (Appendix, Fig. 81) as well as Zea mays (Appendix, Fig. 85).

\subsection{Conclusion}

This paper provides the first documentation of the pollen and spore diversity in marine sediments from the Java Sea and SE Indian Ocean and presents microphotographic images of 138 pollen/41 spore types, including 124/9 identified and 14/32 unidentified types. We consider this set of digital photographs taken with a light microscope on different focal levels as a base for the further palynological and palaeoecological work. It may help as the comprehensive reference for morphology and taxonomy of fossil pollen and spores recovered from marine sediments in Indonesia and to be the good start for the future detailed studies on such a rich and diverse pollen flora in 
Indonesia. However, our knowledge on the pollen and spore flora of the region is still limited, the list of pollen and spores is far from being completed and additional investigations are required.

\subsection{Acknowledgements}

Marine sediment cores for this study were taken during the scientific cruises of the RV "Baruna Jaya" and cruises of unknown RV in 1995-1998. The authors express their gratitude to the crew, scientific and technical assistants for their help. We acknowledge Uta Nüsse-Hahne for the assistance in the laboratory. Mirijam Kiggen and Johana Brockhaus are thanked for their help with the preparing pollen and spore images for the publication. Professor Norm Catto, Editor-in-Chief of the 'Quaternary International' and two anonymous reviewers are acknowledged for critically reviewing the manuscript and for their detailed and useful comments and suggestions. The financial support by the German Ministry of Education and Science (Bundesministerium für Bildung und Forschung), SPICE III - CAFINDO, Grant No. 03F0645C is gratefully appreciated.

\subsection{References}

Adam, J.H., Wilcock, C.C., 1999. Palynological study of Borneo Nepenthes (Nepenthaceae). Pertanika Journal of Tropical Agricultural Science 22, 1-7.

Ahmad, S.M., Guichard, F., Hardjawidjaksana, K., Adisaputra, M.K., Labeyrie, L., 1995. Late Quaternary Paleoceanography of the Banda Sea. Marine Geology 122, 385-397.

An update of the Angiosperm Phylogeny Group classification for the orders and families of flowering plants: APG III (The Angiosperm Phylogeny Group). Botanical Journal of the Linnean Society 161, 105-121

Anderson, J.A.R., Muller, J., 1975. Palynological study of a Holocene peat and a Miocene coal deposit from N.W. Borneo. Review of Palaeobotany and Palynology 19, 291-351.

Anderson, P.M., Brubaker, L.B., 1986 Modern pollen assemblages from northern Alaska. Review of Palaeobotany and Palynology 46, 273-291.

APSA Members (Haberle, S., Rowe, C., Hungerford, S., Preston, T., Warren, P., Hope, G., Hopf, F., Thornhill, A., Stevenson, J., Weng., C., Shimeld, P., Bowman, D., . van der Kaars, S., Sniderman, K.), 2007. The Australasian Pollen and Spore Atlas V1.0. Australian National University, Canberra. Available from: http://apsa.anu.edu.au/

Ashton, P.S., 1982. Dipterocarpaceae. Flora Malesiana series 1 (9), 237-552.

Atahan, P., Itzstein-Davey F., Taylor, D., Dodson, J., Qind, J., Zheng, H., Brooks, A., 2006. Holoceneaged sedimentary records of environmental changes and early agriculture in the lower Yangtze, China. Quaternary Science Reviews 27, 556-570.

Backer, C.A., van den Brink, B., 1965. Flora of Java. Volumes I-III. N. V. P. Noordhoff, Groningen.

Barmawidjaja, B.M., Rohling, E.J., van der Kaars, S. A., Vergnaud, G.C., Zachariasse, W.J., 1993. Glacial conditions of the northern Molucca Sea region (Indonesia). Palaeogeography, Palaeoclimatology, Palaeoecology 101, 147-167. 
Beaufort, L., de Garidel-Thoron, T., Linsley, B., Oppo, D., Buchet, N., 2003. Biomass burning and oceanic primary production estimates in the Sulu Sea area over the last $380 \mathrm{kyr}$ and the East Asian monsoon dynamics. Marine Geology 201, 53-65.

Buchner, R., Weber, M. (2000 onwards). PalDat - a palynological database: Descriptions, illustrations, identification, and information retrieval. Available from: http://www.paldat.org.

Bush, M.B., Weng, C., 2007. Introducing a new (freeware) tool for palynology. Journal of Biogeography 34, 377-380.

$\begin{array}{lllll}\text { Cambridge University } & \text { Palynological Online Database (QPG), } 2008 .\end{array}$ http://www.quaternary.group.cam.ac.uk/pollen/Cranwell, L.M., 1942. New Zealand pollen studies I. Key to the pollen grains of families and genera in the native flora. Records of the Auckland Institute and Museum 2, 269-308.

Caratini, C., Tissot, C., 1988. Paleogeographical evolution of the Mahakam Delta in Kalimantan, Indonesia during the Quaternary and Late Pliocene. Review of Palaeobotany and Palynology 55, 217-228.

Chaturvedi, M., Datta, K., Nair, P. K. K., 1998. Pollen morphology of Oryza (Poaceae), Grana 37 (2), 79-86, DOI: 10.1080/00173139809362647.

Cheddadi, E., 2002. European Pollen Database. IGBP PAGES/World Data Centre for Paleoclimatology. NOAA/NGDC. Palaeoclimatology Program, Bolder, CO. U.S.A. Available from: http://www.ngdc.noaa.gov/paleo/pollen.html.

Davis, O. K., 1995. Climate and vegetation patterns in surface samples from arid western U.S.A: application to Holocene climate reconstruction. Review of Palaeobotany and Palynology 19, 95117.

English homepage of the Indonesian Wetlands. Available from: http://wetlands.or.id/.

Erdtman, G., 1952. Pollen morphology and plant taxonomy. I Angiospermae. Stockholm and Waltham, Mass.

Erdtman, G., 1957. Pollen morphology and plant taxonomy. II Gymnospermae, Pteridophyta, Bryophyta. Stockholm and New York.

Faegri, K., Iversen, J., 1975. Textbook of Pollen Analysis, 4th Ed. Chichester, J. Wiley and Sons Ltd.

Fujiki, T., Zhou, Z., Yasuda, Ya., 2005. The pollen Flora of Yunnan, China. New Delhi, Lustre Press/Roli Books.

Gajewski, K., 2005. The Canadian Pollen Database. Laboratory for Paleoclimatology and Climatology, Department of Geography University of Ottawa, Ontario Canada. Geographers 41(1), 58-72.

GeoNetwork Opensource. Open Source Geospatial Foundation (OSGeo). Available from: http://geonetwork-opensource.org.

Grimm, E., 2000. North America Pollen Database. IGBP PAGES/World Data Centre for Paleoclimatology. NOAA/NGDC. Palaeoclimatology Program, Bolder, CO. U.S.A. Available from: http://www.ngdc.noaa.gov/paleo/pollen.html.

Guinet, P., 1962. Pollens d'Asia tropicale. Travaux Section Scientifique et Technique, Institut Francais Pondichery 5 (1), 1-8 (including 52 plates).

Honjo, S., Doherty, K.W., 1988. Large aperture time-series sediment traps: Design, objectives, construction and application. Deep-Sea Research 35 (1), 133-149.

Hooghiemstra, H., van Geel, B., 1998. World list of Quaternary pollen and spore atlases. Review of Palaeobotany and Palynology 104, 157-182. Available from:http://www.lpc.uottawa.ca/data/cpd.

Huang, T.-C., 1972. Pollen Flora of Taiwan. National Taiwan University, Botany Department Press, Taiwan. 
Huang, T.-C., 1981. Spore Flora of Taiwan (Pteridophyta). National Taiwan University, Taiwan.

Jacobs, M. 1988. The tropical rain forest. A first encounter. Springer-Verlag, Berlin.

Jago, L.C.F., Boyd, W.E., 2003. A GIS atlas of the fossil pollen and modern records of Ficus and related species for Island Southeast Asia, Australasia and the Western Pacific. Australian Geographical Studies 41(1), 58-72.

Jagudilla-Bulalacao, L., 1997. Pollen flora of the Philippines, Vol. 1. DOST-TAPI-SPU Technology Application and Promotion Institute.

Jones, S., E., Pearce, K., G., 2014. A pollen morphology study from the Kelabit Highlands of Sarawak, Malaysian Borneo, Palynology, DOI: 10.1080/01916122.2014.940472

Kartawinata, K. R., Abdulhadi, T., Paromihardjo, 1981. Composition and structure of a lowland Dipterocarp forest at Wanariset, East Kalimantan. Malaysian Forester 44 (2-3), 397-406.

Kiew, R., Muid, M., 1991. Beekeeping in Malaysia: pollen atlas. Serdang, Selangor, Malaysia.

Kodela, P.G., 2000. Pollen morphology of some rainforest taxa occurring in Illawarra region of New South Weles, Australia. Telopea 11 (3), 346-389.

Lang, G., 1994. Quartäre Vegetationsgeschichte Europas. Gustav Fischer Verlag Jena, Stuttgart, New York.

Lézine, A.-M., 2005. African Pollen Database. Available from: http://medias.obsmip.fr/apd/accueil.htm.

MacKinnon, K. S., 1992. Wildlife of Indonesia. Jakarta, Gramedia.

MacKinnon, K., Hatta, G., Halim, H., Mangalik, A., 1997. The Ecology of Kalimantan. The Ecology of Indonesia Series. Singapore, Peripus Editions.

MacKinnon, K., S., 1986. The conversation status of non-human primates in Indonesia. In: K. Benirschke. Primates: the road to self-sustaining populations. New York, Springer.

Maloney, B.K., 1990. Grass pollen and the origins of rice agriculture in north Sumatra. Modern Quaternary Research in Southeast Asia 11, 135-160.

Mao, L., Batten, D., Fujiki, T., Li, Z., Dai, L., Weng, Ch., 2012. Key to mangrove pollen and spores of southern China: an aid to palynological interpretation of Quaternary Deposits in the Southern China Sea. Review of Palaeobotany and Palynology 176-177, 41-67.

Marchant, R., Almeida, L., Behling, H., Berrio, J. C., Bush, M., Cleef, A., Duivenvoorden, J., Kappelle, M., De Oliveira, P., Teixeira de Oliveira-Filho, A., Lozano-Garćia, S., Hooghiemstra, H., Ledru, M. P., Ludlow-Wiechers, B., Markgraf, V., Mancini, V., Paez, M., Prieto, A., Rangel, O., Salgado-Labouriau, M. L., 2002. Distribution and ecology of parent taxa of pollen lodged within the Latin American Pollen Database. Review of Palaeobotany and Palynology 121, 1-75.

Moore, P.D., Webb, J.A., 1978. An illustrated guide to pollen analysis. London, Hodder and Stoughton.

Poliakova A., Rixen T., Jennerjahn, T., Behling, H., 2014. Annual High Resolution Pollen and Spore Sedimentation Record off SW Java in the Indian Ocean. Marine Micropalaeontology 111, 90-99.

Punt, W., Blackmore, S., Hoen, P., Stafford, P., 2003. The Northwest European Pollen Flora. Elsevier Science, London. Available from: http://www.bio.uu.nl/ palaeo/Research2/NEPF/nepf.htm.

Punt, W., Hoen, P.P., Blackmore, S., Nilsson, S., Le Thomas, A., 2007. Glossary of pollen and spore terminology. Review of Palaeobotany and Palynology 143, 1-81.

Rijksen, H. D., Meijaard, E., 1999. Our vanishing relative: the status of wild orang-utans at the close of the twentieth century. Netherlands, Springer.

Rowe, C., 2006. The Australasian Pollen and Spore Atlas User Document. PalaeoWorks: Australian National University Technical Report 8.

Rubeli, K., 1986. Tropical Rain Forest in South-East Asia. Kuala Lumpur, Tropical Press. 
Sofiyanti, N., Yen, Ch., C., 2012. Morphology of ovule, seed and pollen grain of Rafflesia R. Br. (Rafflesiaceae). Bangladesh Journal of Plant Taxonomy 19(2), 109-117.

Southon, J., Kashgarian, M., Fontugne, M., Metivier, B., Yim, W.W.S., 2002. Marine reservoir corrections for the Indian Ocean and Southeast Asia. Radiocarbon 44 (1), 167-80.

Spooner, M.I., Barrows, T.T., De Deckker, P., Paterne, M., 2005. Palaeoceanography of the Banda Sea, and Late Pleistocene initiation of the Northwest Monsoon. Global and Planetary Change 49 (1 -2), 28-46.

Stevenson, J., 2005. New Caledonia pollen flora. Extract of pollen and spore images from Appendix 2 in Stevenson, Late Quaternary Environmental Change and the Impact of Melanesian Colonisation in New Caledonia. Unpublished PhD Thesis, University of New South Wales, Kensington.

Stibig, H-J., Beuchle, R., Janvier, P. 2002. Forest cover map of Insular Southeast Asia at 1:5500000. TREES Publications Series D: No. 3, European Commission, Luxemburg.

Stuijts, I., 1993. Late Pleistocene and Holocene vegetation of West Java, Indonesia. Modern Quaternary Research in South-East Asia 12, 1- 173.

Stuiver, M., Polach, H., 1977. Reporting of 14C data. Radiocarbon 19, 355-363.

Stuiver, M., Reimer, P.J., 1993. Extended 14C data base and revised CALIB $3.014 \mathrm{C}$ age calibration programme. Radiocarbon 35 (1), 215-230.

Tilak, S.T., 1989. Airborne pollen and fungal spores. Vaijayanty Prakashan, Aurangabad.

Van der Kaars, S., 1991. Palynology of eastern Indonesian piston cores: a Late Quaternary vegetational and climatic record for Australasia. Palaeogeography, Palaeoclimatology, Palaeoecology 85, 239-302.

Van der Kaars, S.A., 1993. Pollen morphology of main taxa from the Southeast Asian archipelago. Unpublished internal document, Institute of Earth Sciences, Free University of Amsterdam and Hugo de Vries laboratory, University of Amsterdam (including 20 plates).

Van der Kaars, S., Dam, M., 1995. A 135,000 year record of vegetational and climatic change from the Nadung area, WestJava, Indonesia. Palaeogeography, Palaeoclimatology, Palaeoecology 117, 5572.

Van der Kaars, S., Wang, X., Kershaw, A.P., Guichard, F., Setiabudi, D.A., 2000. A Late Quaternary palaeoecological record fromthe Banda Sea, Indonesia: patterns of vegetation, climate and biomass burning in Indonesia and northern Australia. Palaeogeography, Palaeoclimatology, Palaeoecology 155, 135-153.

Van der Kaars, S., Bassinot, F., De Deckker, P., Guichard, F., 2010. Changes in monsoon and ocean circulation and the vegetation cover of southwest Sumatra through the last 83,000 years: the record form marine core BAR94-42. Palaeogeography, Palaeoclimatology, Palaeoecology 296, 5278.

Van der Kaars, S., Williams, M.A.J., Bassinot, F., Guichard, F., Moreno, E., Dewilde, F., Cook, E.K., 2012. The influence of the 73 ka Toba super-eruption on the ecosystems of northern Sumatra as recorded in marine core BAR94-25. Quaternary International 258, 45-53.

Van Steenis, C.G.G.J., 1984. Floristic altitudinal zones in Malaysia. Botanical Journal of the Linnean Society 89, 289-292.

Van Waveren, I.M., 1989. Palynofacies analysis of surface sediments from the northeastern Banda Sea (Indonesia). Netherlands Journal of Sea Research 24 (4), 501-509.

Visser, K., Thunell, R., Goni, M.A., 2004. Glacial-interglacial organic carbon record from the Makassar Strait, Indonesia: implications for regional changes in continental vegetation. Quaternary Science Reviews 23, 17-27. 
Wang, F., Chien, N., Yulong, Z., Huiqui, Y., 1995. Pollen flora of China. Second edition. Beijing, Institute of botany, Academia Sinica.

Wang, X., van der Kaars, S., Kershaw, A.P., Bird, M., Jansen, F., 1999. A record of vegetation and climate through the last three glacial cycles from Lombok Ridge core G6-4, eastern Indian Ocean, Indonesia. Palaeogeography, Palaeoclimatology, Palaeoecology 147, 241-256.

Webb, T.III, McAndrews, J.H., 1976. Corresponding patterns of contemporary pollen and vegetation in central North America. Geological Society of America Memoirs 145, 267-299.

Whitmore, T.C., 1984. Tropical rain forests of the Far East. (2nd ed.). Oxford University Press, Oxford.

Whitten, A. J., Damanik, S.J., Anwar, J., Hisyam, N., 1987a. The ecology of Sumatra, second edition. Yogyakarta, Gadjah Mada University Press.

Whitten, A.J., Mustafa, M., Henderson, G.S., 1987b. The ecology of Sulawesi. Yogyakarta, Indonesia: Gadjah Mada University Press.

Whitten, T., Soeriaatmadja, R.E., Afiff, S.A., 1996. The Ecology of Java and Bali. Singapore, Periplus Editions.

Yulianto, E., Sukapti, W.S., Rahardjo, A.T., Noeradi. D., Siregar, D.A., Suparan. P., Hirakawa, K., 2004. Mangrove shoreline responses to Holocene environmental change, Makassar Strait, Indonesia. Review of Palaeobotany and Palynology 131 (3-4), 251-268. 


\section{CHAPTER 7}

\section{Overall discussion and synthesis}

\subsection{Main research outcomes and discussion}

Our studies presented in the previous chapters evidenced that marine sediment material from the Java Sea has a good potential to be used for the palaeoenvironmental reconstruction in Kalimantan and Java. The total of four sequences from the mouth of the River Jelai (core 1412-19, SE Kalimantan), off the River Pembuang (core 1412-23, S Kalimantan) and from the water plume of the River Solo (cores 1609-30, NE Java) contributed to a general picture the of late Holocene environment in Indonesia and SE Asia. In order to obtain possibly more detailed information, a combination of terrestrially-born proxies, such as pollen/spores and microcharcoal were used together with the water-born proxies, i.e. organic-walled dinocysts. This approach helped to enhance our overall knowledge of environment dynamics, history of vegetation and land use in the region, spanning over the last ca 3500 cal years. This novel data can be compared and contrasted with other terrestrial and marine environmental records from the region. In this chapter we derive main outcomes of our work, discuss open questions and give an outlook to the further possible perspectives of marine palynology in Indonesia.

\subsubsection{Relations between vegetation and pollen}

The issue of relations between vegetation and pollen was addressed in chapters $\mathbf{3}$ and $\mathbf{5}$. Fossil pollen and spore diversity in the sediment material from the Java Sea reflected neighboring regional vegetation sufficiently; most of vegetation types both from NE Java (the River Solo catchment) and S Kalimantan (basins of the rivers Jelai and Pembuang) are well represented in the pollen assemblages (chapter 5). The highest pollen diversity and abundance was detected for Kalimantan and was corresponded to the wet lowland evergreen rainforest. The most abundant pollen group in Java was adjacent to the secondary vegetation and accounted up to $60 \%$ of total pollen sum. Pollen from mangroves and submontane/lower montane forest reliably show dynamics of these vegetation types through the time, whilst dry lowland forest and upper montane forest taxa were underrepresented 
in pollen from all studied cores. Specific and widely distributed in Kalimantan peat swamp forest were evidenced from high abundances of Engelhardia pollen as well as from the presence of Myricaceae, Ilex, Pandanus, and Durio pollen. Dipterocarp forest was represented by Hopea, Shorea, and indeterminate pollen of Dipterocarpaceae. At present, this forest type is virtually absent from Java, this explains why it was not evidenced for the modern sediments collected with the sediment trap JAM-2 (chapter 2), although grains of Dipterocarpaceae were found off the River Solo in sediments dated back to ca 820 cal yr BP and earlier (chapter 3).

Aquatic vegetation was reflected poorly, by two pollen types (Typha and Cyperaceae indet.) only. Palynologically, herb diversity in Java, where extensive open shrub- and grasslands occur since ca 500-800 cal yr BP (Chapter 1, Fig. 1.5. and literature cited), were higher and better reflected than in Kalimantan. Among the land-use indicators, in most of the modern samples were found an increased abundance of Arecaceae pollen, particularly Arenga that could have been started to be cultivated for its fiber and as a source of sugar (Stuijts, 1993) since ca 1000 cal yr BP; large-grained Poaceae, e.g. Orhiza type and Zea mays help to evidence agriculture. For Java, additional indicator of human activity in a form of reforestation could be increased abundance of the Eucalyptus and Pinus pollen that may point to plantation development as it was suggested by Van der Kaars and van den Bergh (2004).

As the sediment trap study has shown (chapter 2), marked amount of accumulated pollen could be related to the long distance transport from continental part of SE Asia and Sumatra (from 7\% to $17 \%$ of total pollen sum) during NW monsoon season from N Australia (up to $10 \%$ of total pollen sum) during the SE monsoon. Vesiculate pollen (e.g. Pinus and Picea) as well as Alnus, Quercus and some herbaceous pollen types like Ranunculaceae indet. and Thymeliaceae indet. could become a subject of aeolian and marine translocation between mid-December and beginning of March, while from beginning of July till November pollen of Casuarina and Eucalyptus can contribute. Since all of these taxa also naturally grow or are planted in SW Java, it is difficult to make unequivocal conclusions with regard to origin of this pollen in marine sediments.

Maxima of some pollen types (i.e. Elaeocarpus, Myrica, Dacrycarpus, Casuarina, and Podocarpus) are connected with the flowering periods of related trees. Our work shown that regional patterns of pollen are strongly dependent on the reversal system of winds and marine currents, especially in monsoon-induced climate like one in Indonesia.

7.1.2. Late Holocene vegetation, climate and human impact in Kalimantan and Java inferred from marine and terrestrial proxies 
The last ca 3500 years vegetation and land use history of Java (the River Solo catchment) and Kalimantan (basin of the River Jelai) were in a focus of our interest in the chapter 3 . Main environmental changes indicated for both islands were related to human activity. A decline in primary forest taxa, as it has been reviled for such commercially important timber tree taxa as Agathis, Allophylus, Dacrycarpus, Dacrydium, Dipterocarpaceae, Phyllocladus, and Podocarpus, are a subject of logging in the study area. These changes were correspondent to the increase in pollen of pioneer (e.g. Acalypha, Ficus, Macaranga/Mallotus, and Trema) and herb taxa indicating openings in the canopy and development of secondary vegetation. In Java, these changes started about ca 2950 cal yr BP that is much earlier than in Kalimantan where the first changes recorded at ca 910 cal yr BP and were less intensive.

\subsubsection{Late Holocene environment in the Java Sea}

Dinocyst and biogeochemical analysis as two independent methods were applied to a set of the sediment samples obtained off the Pembuang River mouth (SE Kalimantan, chapter 4) and show good correlation. The sedimentary sequences revealed four major units, which were corresponded with distinct environmental changes. The first unit (between 2850 and $2480 \mathrm{cal}$ yr BP) indicated tropical fully-marine and shallow water environment that is characterized by a relatively low productivity and is generally similar to recent conditions. Foraminifera and cocolithophores probably dominated the phytoplankton over dinoflagellates and diatoms. After $2480 \mathrm{cal}$ yr BP water ventilation apparently enchased as it was reviled from the elimination of the oxygen-degradable heterotrophic dinocysts. Typically open-water dinocyst association had been gradually changed by neritic one between ca 2040 and 1530 cal yr BP. Afterwards, before ca 990 cal yr BP, more pronounced influence of the Pembuang River was suggested by the increase of $\delta^{15} \mathrm{~N}$ and decreased $\delta^{13}$ Corg values. That is supported by the occurrence of Lingulodinium machaerophorum and Nematosphaeropsis labyrinthus, good indicators of fresh water input and increased wash-off from land.

A gradual change from relatively well ventilated to more hypoxic bottom/pore water conditions in a more eutrophic environment were also reflected by the dinoflagellate cyst association off the Jelai and the Solo rivers (chapter $\mathbf{3}$ ), which well corresponds to the changes in vegetation on land. Near the coast of Java, the shift of the water trophic status took place between ca 820 and 500 cal yr BP, while near the coast of Kalimantan it occurred as late as at the beginning of the 20th century. Increasing amount of certain types of dinocysts, e.g. cysts of Polykrikos schwartzii and P. kofoidii, Lingulodinium machaerophorum, Nematosphaeropsis labyrinthus, Selenopemphix nephroides at times of secondary vegetation development on land, pointed to the enhanced input of nitrogen and 
phosphorus that may be a result of human induced terrestrial changes such as vegetation cover disturbance and soil erosion. Occurrence of these dinocysts were strongly positively correlated with the increase in pioneer taxa and negatively correlated with increase in pollen taxa related to the primary forest vegetation, suggesting that these taxa may potentially be used as palaeoecological indicators of anthropogenic activity.

The signal of intensive logging on land found about 50-70 years later, than the changes in the dinocysts assemblages in the marine realm of the Java Sea. This is in accordance to the time which is required for the vegetation changing, establishing a pioneer community in and a complete reorganization of the vegetation (chapter 2; Whitmore, 1975; Stuijts, 1993).

\subsection{Open questions}

A number of open questions are still left behind this study, mainly, due to the fact that marine palynology in Indonesia is a young area of science and also because of the peculiarities of the study area. First of all, a lot more detailed research on the regional patterns of modern pollen spectra in the Indonesian waters as well as on factors influencing them are required. As our study reviled it for the SE Indian Ocean (Chapter 3), both regionally produced pollen and the one brought from a long distances are collected in marine sediments. The proportion of pollen originated from different vegetation sources changes due to the seasonal monsoon reversal and, therefore, reversal of marine currents. The picture became even more complex because pollen transport is depend not only on marine and wind currents, but is also controlled by river regime, local precipitation, vegetation specificity (Sun et al., 2002), flowering periods, processes of pollination, pollen production and pollen preservation. The role of all these factors and their relationships are still unclear and opens a room for further investigations. Moreover, winds/marine currents are not only bringing additional amount of pollen from long distance, they obviously also blowing/washing away some of the regionally produced pollen. Amount of this taken away pollen is so far uncertain and needs to be accurately calculated. This task, however, is not a trivial one, as most of registered taxa do have a broad areas of growth and can be found almost everywhere from South China and Malay Peninsula to Indonesian archipelago and North Australia.

With regard to our understanding of the late Holocene (about the last ca 3500 years BP) vegetation patterns in SE Kalimantan and NE Java (Chapter 3), proportion of mountain vegetation, for pollen spectrum of Java especially, seems to be overestimated. Most of Javanese natural forests are destroyed (e.g. Stuijts, 1993) so that the source vegetation for e.g. Dacrycarpus, Dacrydium, Podocarpus and Phillocladus in Java is limited. As this pollen easily travels over long distance, aeolian transport can contribute to the presence of vesiculate pollen of montane coniferous in marine 
sediments (Heusser and Balsam, 1977; Heusser, 1988; Sun, 1999), although the rate of this contribution has not been estimated precisely so far.

Another potential challenge is how to separate riparian and peatland forests species based on pollen types (Chapter 4). As the most of riparian and peatland taxa can also grow elsewhere: in lowland forest (e.g. Anacardiaceae, Celtis, Dipterocarpaceae, Elaeocarpus, and Euphorbiaceae), submontane forest (e.g. Engelhardia and Myrsine) or can originate from the secondary vegetation (e.g. Macaranga/Mallotus and Pandanus), it is difficult to say with no doubt which vegetation type do they represent.

As for the fire records, which show enhanced burning since ca $1500 \mathrm{cal}$ yr BP in East Java and since ca 980 cal yr BP in South Kalimantan, it remains unclear, whether these regional fires were of natural or of anthropogenic origin. Even though it is possible that fires can be lit naturally by lightning or during the hot days of droughts, it is often that fires are lit by people. Slush-and-burn system of agriculture is very popular in Indonesia even nowadays as it is simple, easily available and not only clears the land but also improves the soils by means of adding ash. We do not know exactly when this kind of agriculture has been started, but it is very old and widely used technique. Other reasons to set fire can be e.g. a road construction or a clearing place for a new settlement. Thus, the exact reason for relatively high microcharcoal concentrations in late Holocene sediments of the Java Sea is doubtful. We do not possess so far any evidences to prove or to discard any of above described versions.

Being perfect for research on the land use, forest dynamics, eutrophication and other processes related to human activity, cores 1412-19 (South Kalimantan) and 1609-30 (East Java) did not allow us to make any concrete and unequivocal conclusions on natural dynamics (e.g. connected to climate change or to sea level fluctuations) in the study area. The signals of natural dynamics that we discussed in our work were strongly biased by anthropogenic activity.

In terms on dinocyst analysis, our main uncertainties were connected to cosmopolitan species (i.e. Operculodinium centrocarpum, Spiniferites ramosus, Sp. Pachydermus) and indeterminate types of Spiniferites and Operculodinium) that occur in a broad range of salinity and trophic conditions and build up the most of dinocyst association of the core 1612-23 (Chapter 5). Whilst the most of these species are typical for warm waters, interpretation of their dynamics is difficult to conduct in terms of regional factors. Furthermore, pollen and dinocyst analysis, alike any other methods of relative stratigraphy, are based on a limited sets of radiocarbon data and linear approach in age-depth modelling that could require more accuracy.

In the light microscopy technique as it was used for pollen analysis, the level of taxonomic differentiation is restricted. Thus, in most cases determination of pollen grains was possible on the genus level or a combination of two or more genera, occasionally even on family level (Birks and Birks, 1980; Demske et al., 2013). This restriction can be crucial, for instance, to distinguish with sure 
crop cultures from other Poaceae (e.g. Orhiza type; Chapter 6). Sometimes one pollen/spore "type" can include including several different taxa under the same name, and it is not necessarily that they origin from the same vegetation type (e.g. Moraceae/Urticaceae

and psilate/not well preserved Weinmannia pollen, pollen of Saurauia and Elaeocarpus). In some cases, however, inseparable taxa have almost the same biological and ecological characteristics (e.g. in case of Lithocarpus/Castanopsis or Macaranga/Mallotus) while for the majority of fern spores light microscope determination is almost impossible. Unclear or ambiguous determinations highly influence pollen records reducing their accurateness.

\subsection{Concluding remarks}

The results obtained during this research project give a good illustration to all advantages of a combined use of independent proxies for environmental reconstructions in SE Kalimantan and NE Java as well as in the Java Sea. Pollen/spore and organic-walled dinocyst records, being applied together, allow better and more comprehensive interpretation on palaeoenvironmental conditions of the past. If driven by the same group of factors (e.g. related to human activity), they show a good correlation as our studies on marine sediment cores 1412-19 (South Kalimantan) and 1609-30 (East Java) illustrated. The hypotheses approached at the beginning of these studies can be addressed as following:

(1) Main vegetation communities of SE Kalimantan and NE Java as well as their changes in time are documented in sediments from the Java Sea, although a roll of pollen transported from a long distance (e.g. from the continental Asia, Sumatra, and $N$ Australia) needs to be considered.

(2) Anthropogenic environmental changes play greater role in the dynamics of the past communities in SE Kalimantan and NE Java during the last ca 3500 cal yr; the signals of natural dynamics are strongly biased by anthropogenic activity.

(3) Anthropogenic activity related to land use (e.g. logging, agriculture and plantations development, aquaculture and/or fires) increased during the Late Holocene/Anthropocene, particularly in Java.

(4) Environmental changes are reflected both in pollen/spores and dinoflagellates assemblages; the pollen-based signal from land is delayed about 50-70 years compared to the dinocystsbased signal from the sea.

(5) Anthropogenic environmental changes on the island of Java are evidenced to have started about 2000 yr earlier then on the island of Kalimantan. 


\subsection{Further perspective}

Marine palynology in Indonesia is a young branch of research with an open future and a broad range of perspectives. Many efforts are still can be taken in order to understand all complex of relationships between source vegetation and pollen transportation factors that influence a composition of pollen assemblages in marine sediments. Our knowledge of ecosystem dynamics and climate variability in the region during the late Holocene is still limited by the lack of palaeoecological record. Marine sediments as potential palaeoclimate and palaeoenvironment archives are very promising, and further high-resolution multiproxy are expected in Indonesia, in particular in Kalimantan with its unique ecosystems and long history of vegetation development. We can expect increased interest to marine palynology in Indonesia in the nearest future and may look forward to improve our overall knowledge about magnificent nature of Palaeotropics with all its unique and intricate ecosystems on land and in sea. However, one who dears to come to nature for any, even for scientific purposes, should always remember to be as less destructive as one can.

\subsection{References}

Birks, H.J.B., Birks, H.H., 1980. Quaternary palaeoecology. E. Arnold, London.

Demske, D., Tarasov, P.E., Nakagawa, T., Suigetsu 2006 Project Members, 2013. Atlas of pollen, spores and further non-pollen palynomorphs recorded in the glacial-interglacial late Quaternary sediments of Lake Suigetsu, central Japan. Quaternary International 290-291, 164-238.

Heusser, L., Balsam, W.L., 1977. Pollen distribution in the Northeast Pacific Ocean. Quat. Res., 7:4562.

Heusser, L.E., 1988. Pollen distribution in marine sediments on the continental margin off northern California. Marine Geology 80, 131-147.

Stuijts, I., 1993. Late Pleistocene and Holocene vegetation of West Java, Indonesia. Modern Quaternary Research in South-East Asia 12, 1-173.

Sun, X., Li, X., 1999. A pollen record of the last $37 \mathrm{ka}$ in deep sea core 17940 from the northern slope of the South China Sea. Marine Geology 156, 227-244.

Sun, X.-J., Li, X., Luo, Yu.-L., 2002. Vegetation and climate on the Sunda Shelf of the South China Sea during the Last Glaciation - Pollen results from station 17962. Acta Botanica Sinica 44 (6), 746752.

Van der Kaars S., Van den Bergh, G.D., 2004. Anthropogenic changes in the landscapes of West Java (Indonesia) during historic times, inferred from a sediment and pollen record from Teluk Banten. Journal of Quaternary Science 19 (3), 229-239.

Whitmore, T.C., 1975. Tropical rain forest of the Far East. Clarendon Press, Oxford. 


\section{Appendix A}

Complete lists of identified pollen, spores and organic-walled dinocysts types mentioned in the thesis

Appendix A1. Complete list of pollen and spore types mentioned in the thesis

Appendix A2. Microphotographs of all sporeans pollen types mentioned in the thesis 
Appendix A1. Complete list of pollen and spore types mentioned in the thesis

\begin{tabular}{|c|c|c|c|c|c|c|c|}
\hline name & $\begin{array}{l}\text { pollen / spore } \\
\text { type }\end{array}$ & plate & $\begin{array}{c}\text { sediment } \\
\text { trap } \\
\text { JAM2 }\end{array}$ & $\begin{array}{c}\text { core } \\
1412- \\
19\end{array}$ & $\begin{array}{c}\text { core } \\
1609- \\
30\end{array}$ & $\begin{array}{c}\text { core } \\
1612- \\
23\end{array}$ & $\begin{array}{c}\text { core } \\
1612- \\
26\end{array}$ \\
\hline Davallia & monolate spore & 19 & & * & $*$ & $*$ & \\
\hline Schizaea & monolate spore & 20 & & $*$ & & $*$ & \\
\hline Cyathea & trilate spore & 1 & $*$ & $*$ & $*$ & $*$ & $*$ \\
\hline Disconia & trilate spore & 21 & $*$ & & & $*$ & \\
\hline Huperzia & trilate spore & 22 & $*$ & $*$ & $*$ & $*$ & \\
\hline Lycopodium & trilate spore & 23 & $*$ & $*$ & $*$ & $*$ & $*$ \\
\hline Ophioglossum & trilate spore & 24 & $*$ & $*$ & $*$ & & \\
\hline Selaginella & trilate spore & 2 & $*$ & $*$ & $*$ & $*$ & $*$ \\
\hline Cf. Anthocerus & trilate spore & 25 & & $*$ & & & \\
\hline Acacia & polyade & 50 & & & & $*$ & \\
\hline Acalypha & tricolporate & 117 & $*$ & $*$ & $*$ & $*$ & $*$ \\
\hline Acanthaceae indet. & tricolporate & 69 & $*$ & $*$ & $*$ & $*$ & \\
\hline Agathis & inaperturate & 55 & & $*$ & $*$ & $*$ & \\
\hline Aglaia & tricolporate & 118 & & & & $*$ & \\
\hline Albizia & polyade & 119 & & & & & \\
\hline Alchornea & tricolporate & 51 & $*$ & $*$ & $*$ & $*$ & \\
\hline Ailanthus & tricolporate & 120 & & & & $*$ & \\
\hline Allophylus, type 1 & tricolporate & 86 & $*$ & $*$ & $*$ & & \\
\hline Allophylus, type 2 & tetraporate & 99 & & & & & \\
\hline Alnus, type 1 & tetraporate & 98 & $*$ & $*$ & $*$ & & \\
\hline Alnus, type 2 & 5-porate & 102 & $*$ & & $*$ & $*$ & \\
\hline Altingia & periporate & 106 & & & & $*$ & \\
\hline Amaranthaceae indet. & peripor & 107 & $*$ & $*$ & $*$ & $*$ & \\
\hline Anacardiaceae indet. & tricolporate & 121 & $*$ & $*$ & $*$ & $*$ & \\
\hline Annona & inaperturate & 52 & & & & $*$ & \\
\hline Apiaceae indet. & tricolporate & 122 & & & & $*$ & \\
\hline Arceuthobium & heterocolp & 76 & & & & & \\
\hline Areca & monosulcate & 56 & & & & $*$ & \\
\hline Arecaceae indet., type 1 & monosulcate & 57 & $*$ & $*$ & & $*$ & $*$ \\
\hline Arecaceae indet., type 2 & monosulcate & 58 & $*$ & $*$ & $*$ & $*$ & \\
\hline Arecaceae indet., type 3 & monosulcate & 59 & & * & $*$ & $*$ & \\
\hline Arenga & monosulcate & 60 & $*$ & $*$ & $*$ & $*$ & \\
\hline Artemisia & tricolporate & 123 & & & & $*$ & \\
\hline Asteraceae indet., type 1 & tricolporate & 124 & $*$ & $*$ & $*$ & $*$ & \\
\hline Asteraceae indet., type 2 & tricolporate & 125 & & & $*$ & $*$ & \\
\hline Asteraceae indet., type 3 & tricolporate & 126 & & & $*$ & $*$ & \\
\hline Avicennia & tricolporate & 165 & $*$ & $*$ & $*$ & $*$ & \\
\hline Barringtonia & tricolporate & 127 & & & & & \\
\hline Bignoniaceae indet., type 2 & tricolporate & 128 & $*$ & $*$ & $*$ & $*$ & \\
\hline $\begin{array}{l}\text { Bignoniaceae indet., type } \\
\text { 2/Cf. Lamiaceae indet. }\end{array}$ & peripor & 87 & $*$ & $*$ & $*$ & & \\
\hline Bombacaceae indet. & tricolporate & 129 & & & & $*$ & \\
\hline $\begin{array}{l}\text { Cf. Brassicaceae indet. } \\
\text { type }\end{array}$ & tricolpate & 130 & & & & & \\
\hline Bruguiera & tricolporate & 61 & & $*$ & & $*$ & \\
\hline Calamus & monosulcate & 108 & & & & $*$ & \\
\hline Caryophyllaceae indet. & peripor & 62 & $*$ & $*$ & $*$ & $*$ & \\
\hline Caryota & monosulcate & 131 & $*$ & $*$ & $*$ & $*$ & \\
\hline Casuarina & tricolporate & 88 & $*$ & $*$ & $*$ & $*$ & \\
\hline Celtis & tricolporate & 89 & $*$ & $*$ & $*$ & $*$ & \\
\hline
\end{tabular}




\begin{tabular}{|c|c|c|c|c|c|c|c|}
\hline Centauria & tricolporate & 132 & & & & $*$ & \\
\hline Chloranthaceae indet. & monosulcate & 105 & & $*$ & $*$ & $*$ & \\
\hline $\begin{array}{l}\text { Asteraceae subfamily } \\
\text { Cichorideae indet. }\end{array}$ & fenistrate & 70 & $*$ & $*$ & & & \\
\hline Castanopsis/Lithocarpus & tricolporate & 63 & $*$ & $*$ & $*$ & $*$ & $*$ \\
\hline Clematis & tricolporate & 71 & & & & $*$ & \\
\hline $\begin{array}{l}\text { Combretaceae/ } \\
\text { Melastomataceae indet., } \\
\text { type } 1\end{array}$ & heterocolporate & 133 & $*$ & $*$ & $*$ & $*$ & $*$ \\
\hline $\begin{array}{l}\text { Combretaceae/ } \\
\text { Melastomataceaeindet., } \\
\text { type } 2\end{array}$ & heterocolporate & 77 & $*$ & $*$ & $*$ & $*$ & $*$ \\
\hline Clethra type & tricolporate & 78 & $*$ & $*$ & $*$ & $*$ & \\
\hline Cucurbitaceae indet. & triporate & 90 & $*$ & $*$ & & & \\
\hline Cunoniaceae indet. & dicolpate & 68 & $*$ & $*$ & $*$ & $*$ & \\
\hline Cyperaceae indet. & monoporate & 109 & $*$ & $*$ & $*$ & $*$ & \\
\hline Dacrycarpus type & vesiculate & 42 & $*$ & $*$ & $*$ & $*$ & \\
\hline Dacrydium type & vesiculate & 43 & & & $*$ & & \\
\hline Dillenia & tricolporate & 134 & & & & $*$ & \\
\hline Dipterocarpaceae indet. & tricolporate & 135 & & $*$ & $*$ & $*$ & \\
\hline Durio & tricolporate & 72 & & & & $*$ & \\
\hline Dysoxylum & tetraporate & 100 & & & & $*$ & \\
\hline Elaeocarpus & tricolporate & 136 & $*$ & $*$ & $*$ & $*$ & $*$ \\
\hline Engelhardia & triporate & 91 & $*$ & $*$ & $*$ & $*$ & \\
\hline Ericaceae indet. & tetrade & 53 & $*$ & $*$ & $*$ & $*$ & \\
\hline Eucalyptus & tricolporate & 137 & $*$ & $*$ & $*$ & $*$ & \\
\hline Euphorbiaceae indet. & tricolporate & 138 & $*$ & $*$ & $*$ & $*$ & \\
\hline Fabaceae indet., type 1 & tricolporate & 92 & & $*$ & $*$ & $*$ & \\
\hline Fabaceae indet., type 2 & tricolporate & 139 & & $*$ & & $*$ & \\
\hline Ficus & diporate & 84 & $*$ & $*$ & $*$ & $*$ & \\
\hline Garcinia & tetraporate & 101 & & & & $*$ & \\
\hline Hibiscus & peripor & 110 & & & & $*$ & \\
\hline Hopea & tricolporate & 140 & & & & & \\
\hline Iridaceae/Liliaceae indet & monosulcate & 141 & $*$ & $*$ & $*$ & & \\
\hline Ilex & tricolporate & 64 & $*$ & $*$ & $*$ & & \\
\hline Ixora & tricolporate & 142 & & & & & \\
\hline Juglandaceae indet. & peripor & 111 & & & & $*$ & \\
\hline $\begin{array}{l}\text { Loranthaceae indet., type } \\
1\end{array}$ & tricolporate & 143 & & $*$ & $*$ & $*$ & \\
\hline $\begin{array}{l}\text { Loranthaceae indet., type } \\
2\end{array}$ & tricolporate & 144 & $*$ & $*$ & & & \\
\hline $\begin{array}{l}\text { Loranthaceae indet., type } \\
3\end{array}$ & tricolporate & 145 & & $*$ & $*$ & & \\
\hline Lythraceae indet. & triporate & 146 & $*$ & & & & \\
\hline Macaranga-Mallotus & tricolporate & 147 & $*$ & $*$ & $*$ & $*$ & \\
\hline Malvaceae indet., type 1 & periporate & 148 & $*$ & $*$ & & & \\
\hline Malvaceae indet., type 2 & periporate & 112 & & & $*$ & & \\
\hline Malpighiaceae indet & tricolporate & 113 & & & $*$ & & \\
\hline Meliaceae type & 4-colporate & 163 & & & & & $*$ \\
\hline Mimosaceae indet. type & polyade & 54 & $*$ & $*$ & $*$ & $*$ & \\
\hline $\begin{array}{l}\text { Moraceae/Urticaceae } \\
\text { indet. }\end{array}$ & triporate & 94 & $*$ & $*$ & $*$ & $*$ & $*$ \\
\hline Myrica & tricolporate & 93 & $*$ & $*$ & $*$ & $*$ & $*$ \\
\hline Myrtaceae indet. & tricolporate & 149 & $*$ & $*$ & $*$ & $*$ & \\
\hline Nypa & monosulcate & 65 & $*$ & $*$ & $*$ & $*$ & \\
\hline Oleaceae indet., type 1 & tricolporate & 73 & $*$ & $*$ & $*$ & $*$ & \\
\hline
\end{tabular}




\begin{tabular}{|c|c|c|c|c|c|c|c|}
\hline Oleaceae indet., type 2 & 4-colporate & 164 & $*$ & & $*$ & & \\
\hline Onagraceae indet. & triporate & 95 & & & & $*$ & \\
\hline Oncosperma & monosulcate & 66 & $*$ & $*$ & $*$ & $*$ & \\
\hline Oryza type & monoporate & 79 & $*$ & $*$ & $*$ & & * \\
\hline Pandanus & monoporate & 80 & & & $*$ & $*$ & \\
\hline Phyllocladus & vesiculate & 44 & & $*$ & $*$ & & \\
\hline Picea type & vesiculate & 45 & $*$ & & & & \\
\hline Pinanga & monosulcate & 67 & & & & & \\
\hline Pinus type 1 & vesiculate & 46 & $*$ & $*$ & $*$ & & \\
\hline $\begin{array}{l}\text { Pinus type } 2 \text {. Cf. } P \text {. } \\
\text { sylvestris }\end{array}$ & vesiculate & 47 & $*$ & & & & \\
\hline Plantago & peripor & 114 & $*$ & $*$ & $*$ & $*$ & \\
\hline Plumbaginaceae indet. & tricolpate & 74 & & & & $*$ & \\
\hline Poacaeae indet. & monoporate & 81 & $*$ & $*$ & $*$ & $*$ & $*$ \\
\hline Podocarpus & vesiculate & 48 & $*$ & $*$ & $*$ & $*$ & \\
\hline Polygonaceae indet. & tricolporate & 150 & & & & $*$ & \\
\hline Pometia & triporate & 96 & $*$ & $*$ & $*$ & & \\
\hline Quercus & tricolpate & 151 & $*$ & $*$ & $*$ & $*$ & \\
\hline Quintinia & 5-porate & 104 & & & & $*$ & \\
\hline Ranunculaceae indet. type & tricolpate & 75 & $*$ & & $*$ & & \\
\hline Rhizophora & tricolporate & 152 & $*$ & $*$ & $*$ & $*$ & $*$ \\
\hline Rosaceae indet. type & tricolporate & 153 & $*$ & $*$ & $*$ & $*$ & \\
\hline Rubiaceae indet. & tricolporate & 154 & $*$ & $*$ & $*$ & $*$ & \\
\hline Rutaceae indet. & tricolporate & 155 & $*$ & $*$ & $*$ & $*$ & \\
\hline Salix type & tricolporate & 156 & & $*$ & $*$ & & \\
\hline Sapindaceae indet. & tricolporate & 157 & $*$ & $*$ & $*$ & $*$ & \\
\hline Sapotaceae indet. & tricolporate & 158 & $*$ & $*$ & $*$ & $*$ & \\
\hline Sonneratia & triporate & 97 & & $*$ & $*$ & $*$ & \\
\hline Symplocos & tricolporate & 159 & & & & $*$ & \\
\hline Thalictrum & periporate & 115 & & $*$ & $*$ & $*$ & \\
\hline Thymeliaceae indet. type & inaperturate & 116 & $*$ & $*$ & $*$ & $*$ & \\
\hline Trema & diporate & 85 & $*$ & $*$ & $*$ & $*$ & $*$ \\
\hline Tsuga type & vesiculate & 49 & & & & & $*$ \\
\hline Typha & monoporate & 82 & & $*$ & & & \\
\hline Ulmus & tetraporate & 103 & $*$ & $*$ & $*$ & & * \\
\hline Verbenaceae indet. type & tricolporate & 160 & & & & $*$ & \\
\hline Vitaceae indet. type & tricolporate & 161 & & & & $*$ & \\
\hline Weinmannia & tricolporate & 162 & & $*$ & $*$ & $*$ & \\
\hline Zea mays & monoporate & 83 & $*$ & $*$ & $*$ & & \\
\hline
\end{tabular}

Note: "indet." stays if more precise identification than a lavel of family for some objective resons is not possible; "type" indicates that more than one pollen type can be included; "Cf." - stays for unclear or doubtfull identification; * indicates presence of the pollen/spore type in a sediment core or in the sediment trap samples. Empty cell stays for abcence. 
Appendix A2. Microphotographs of all spore and pollen types mentioned in the thesis

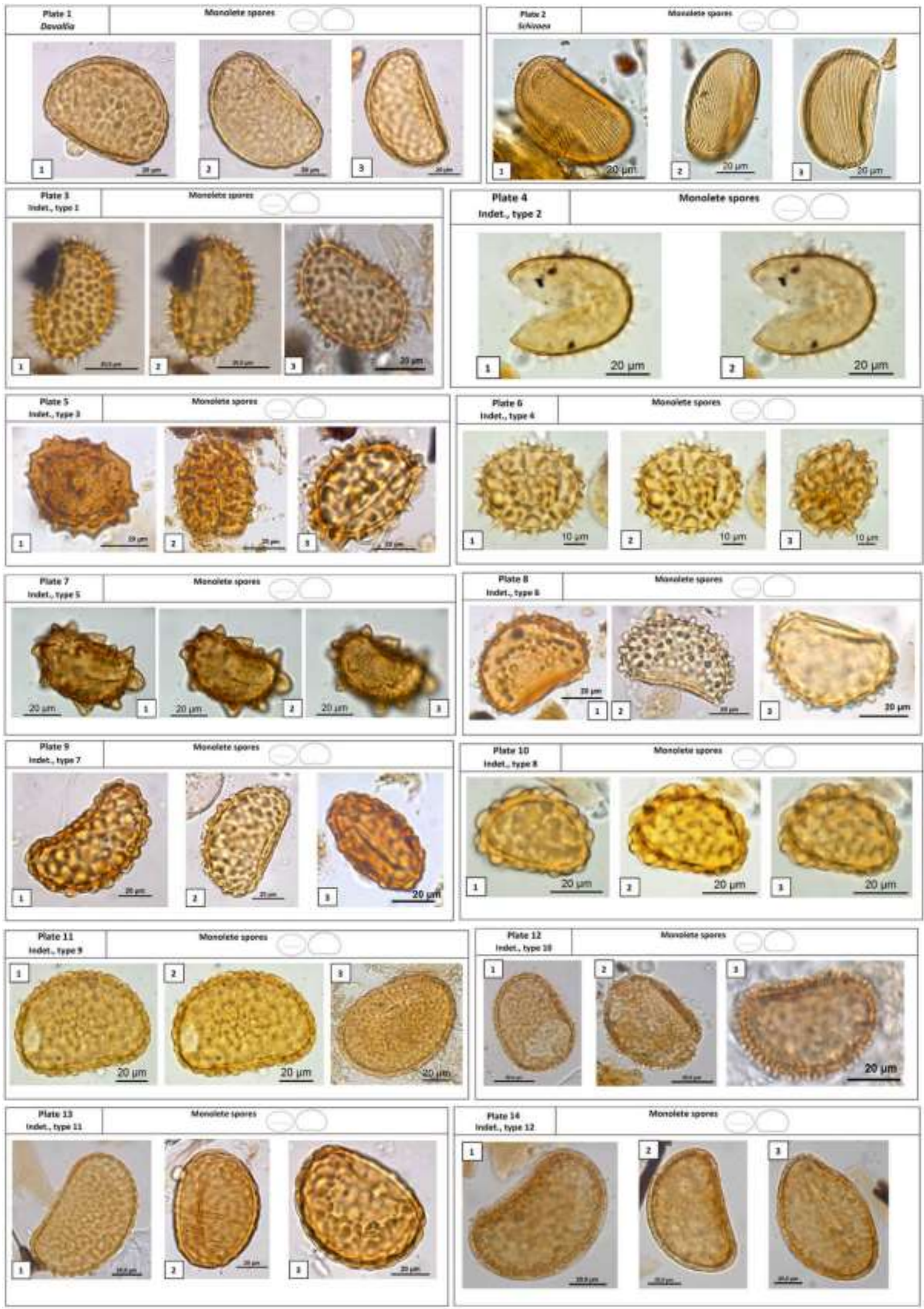



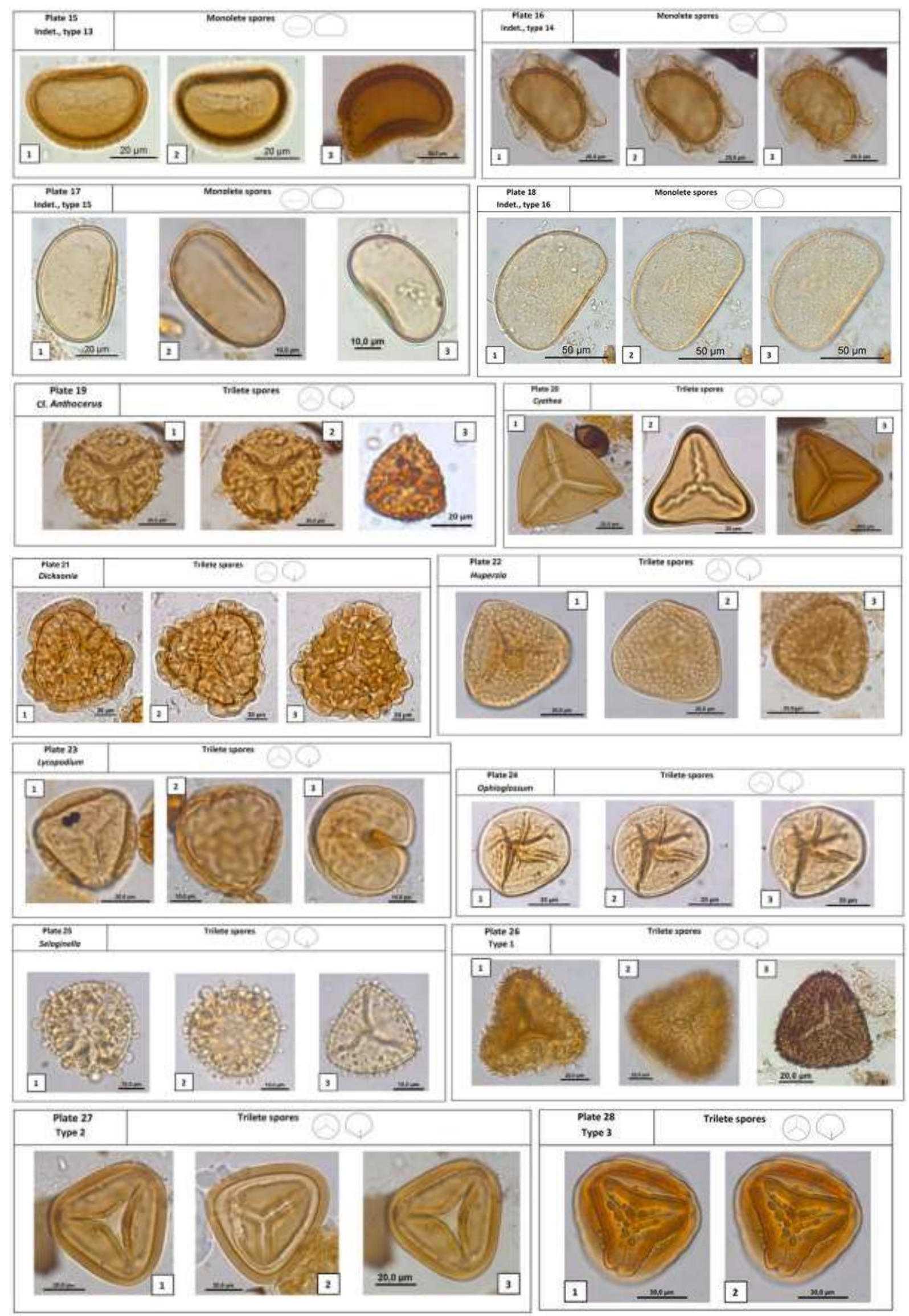

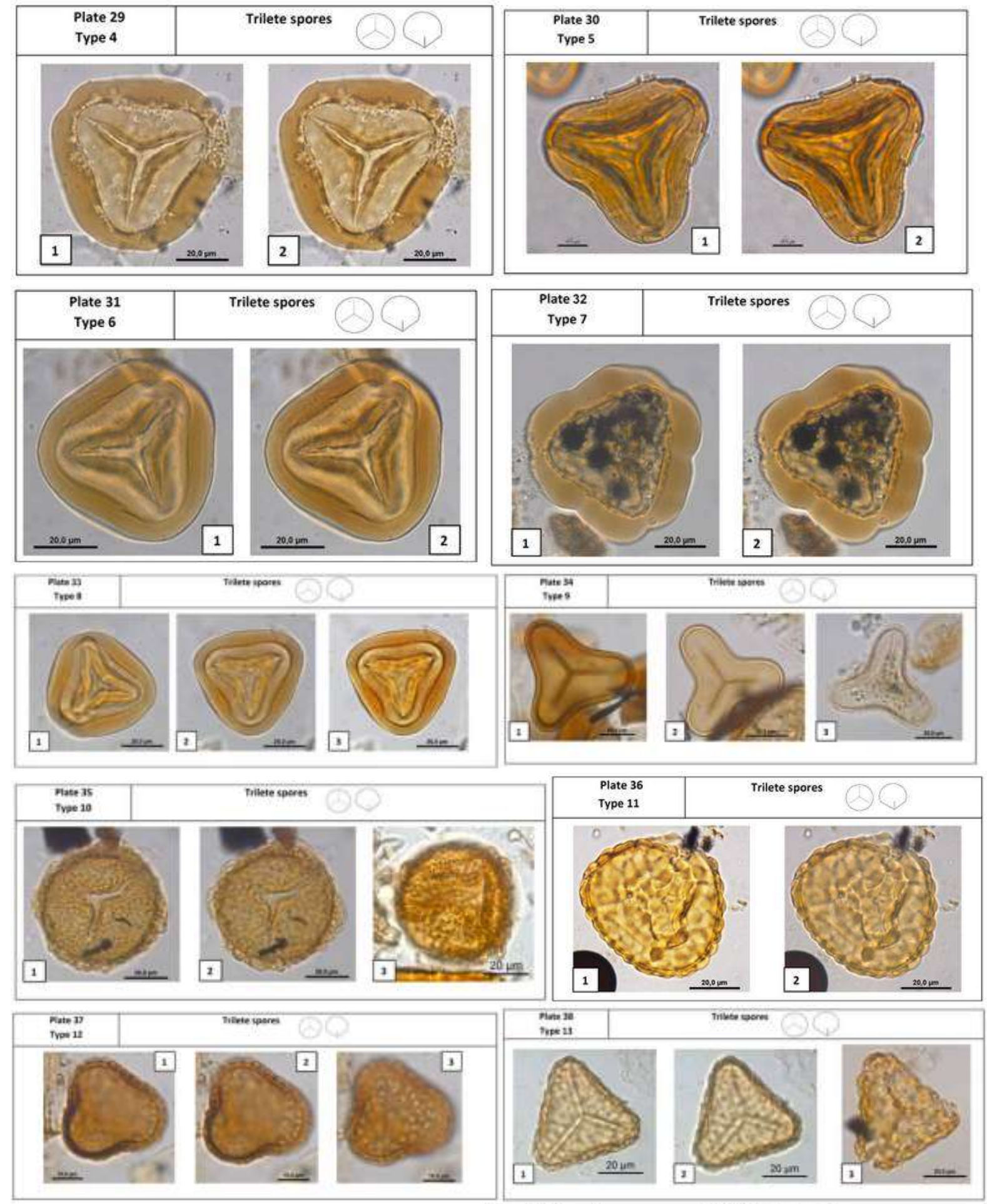

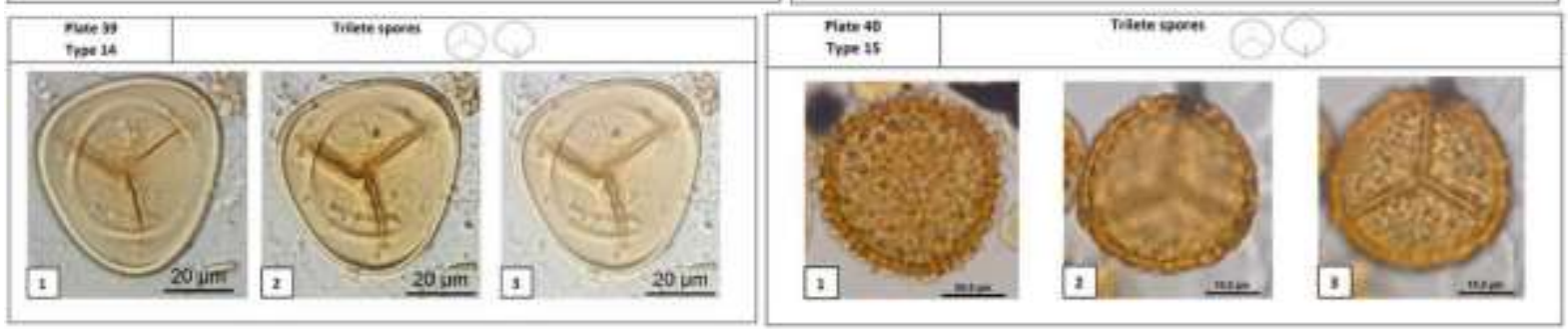



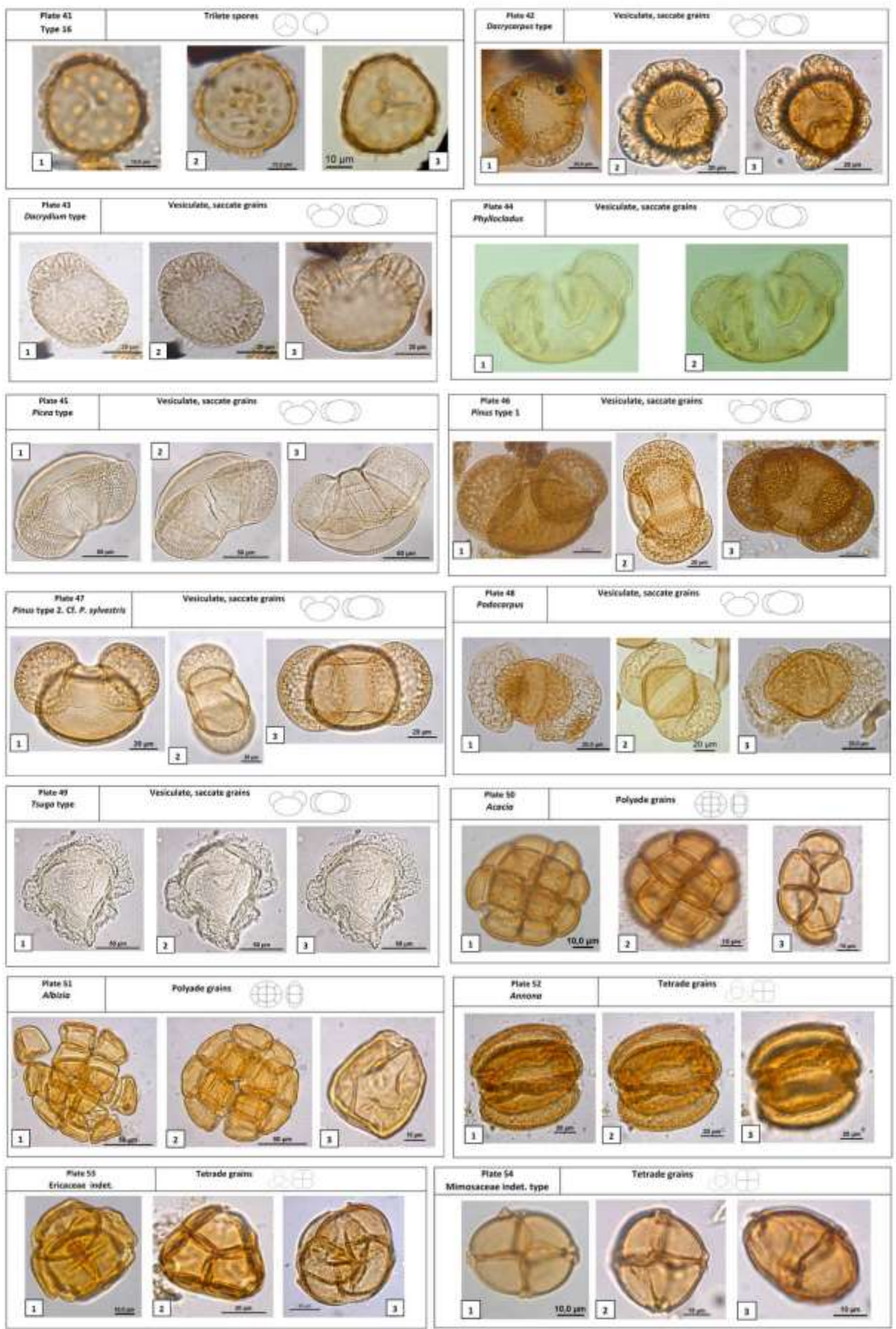

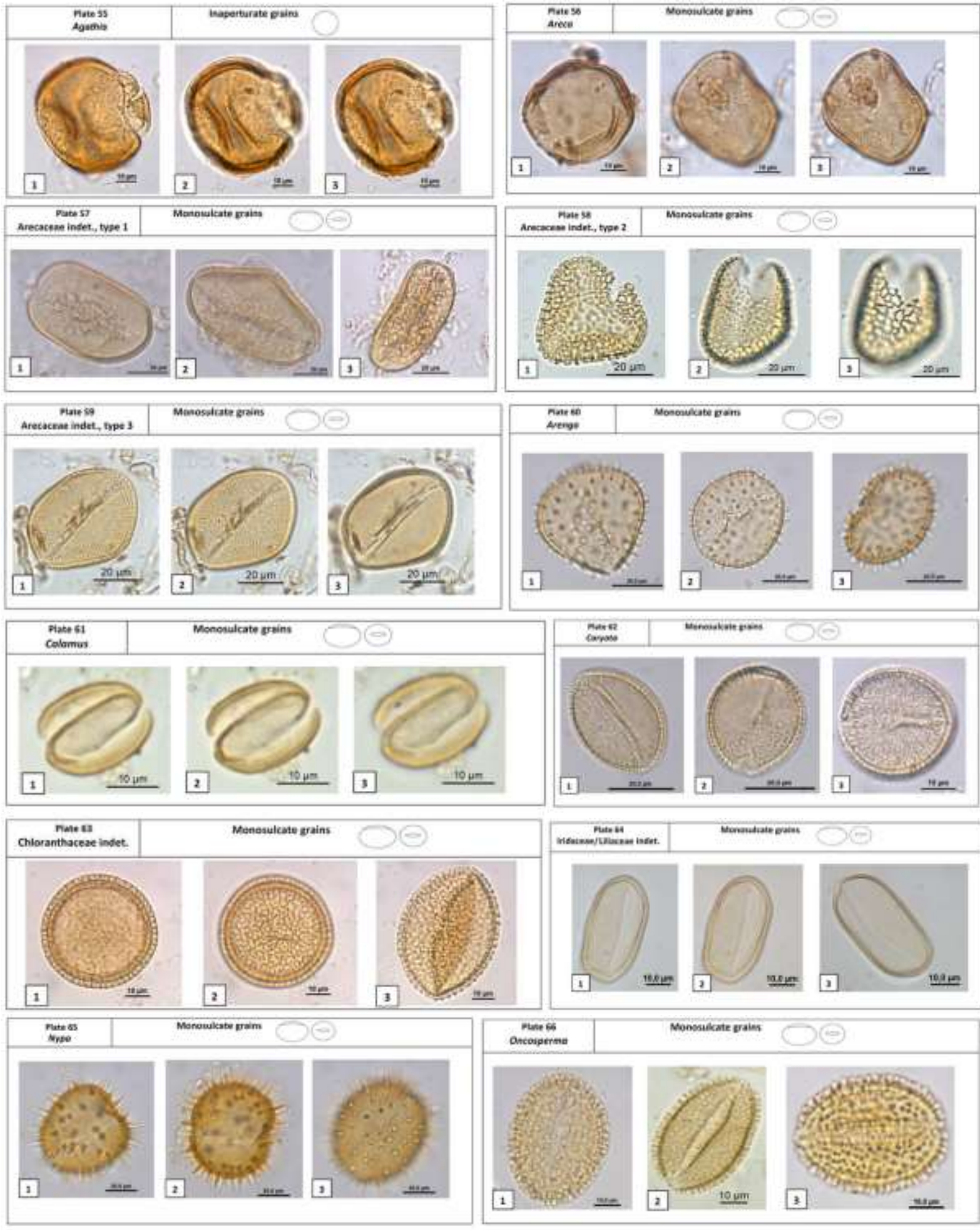

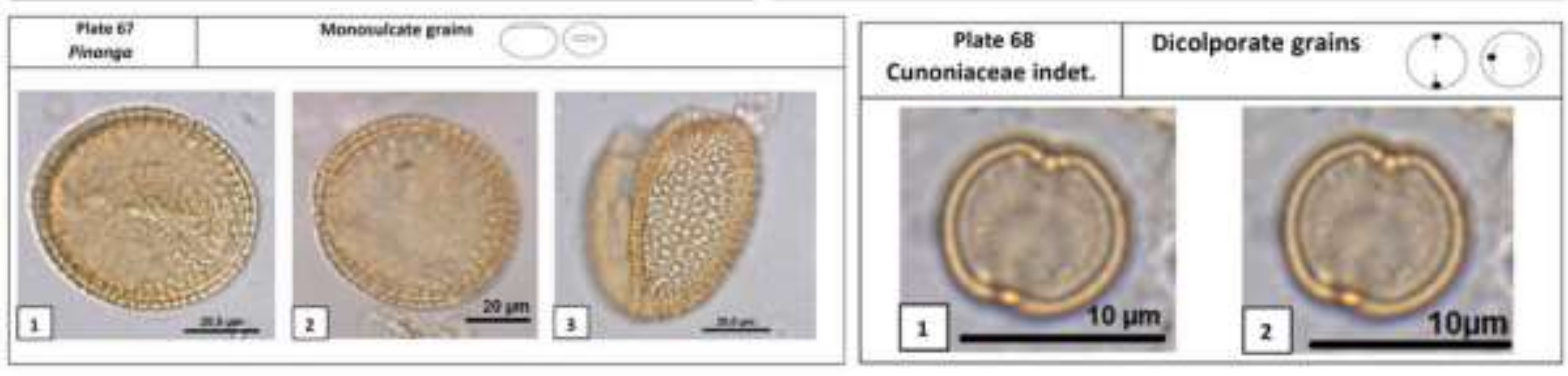



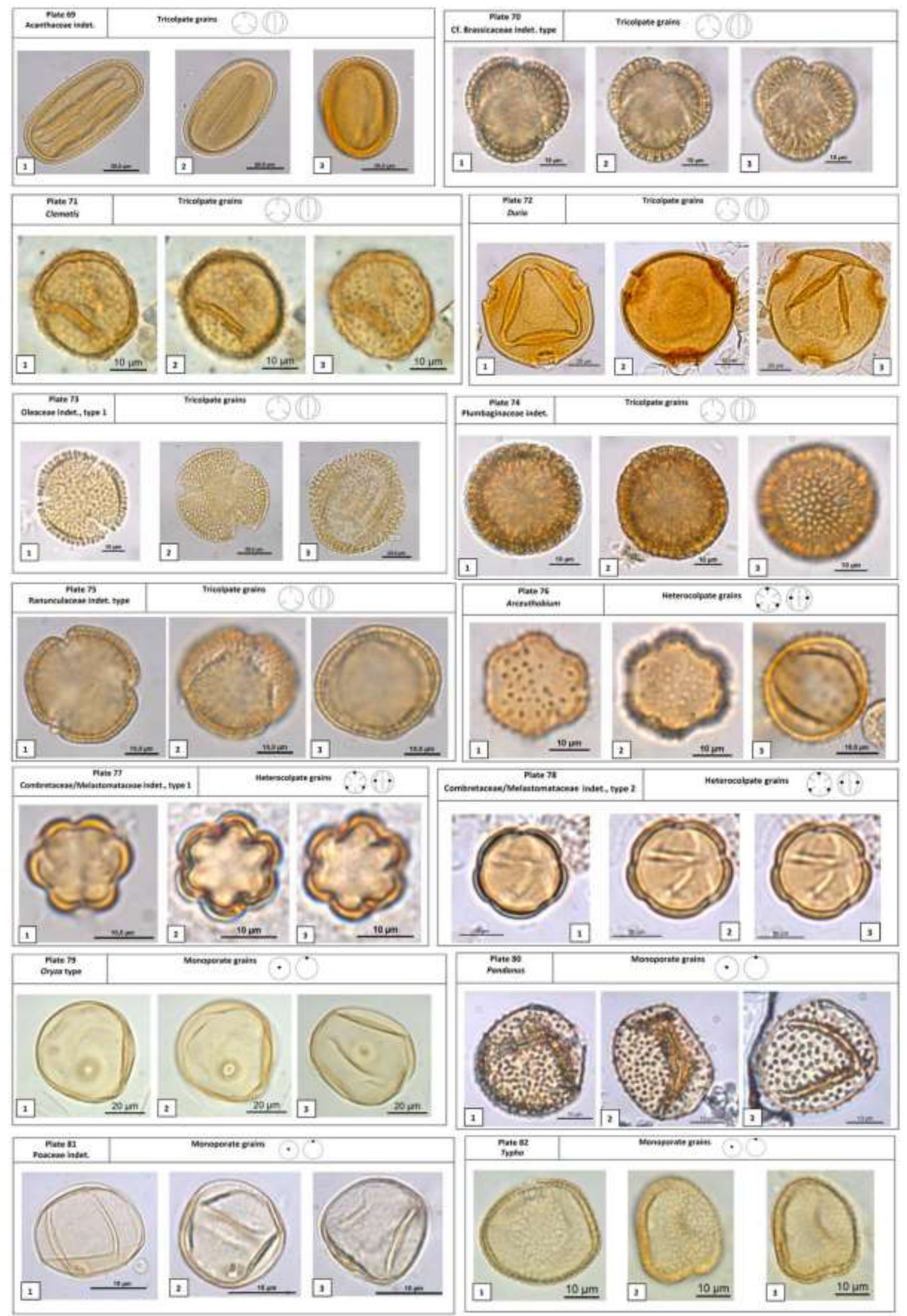

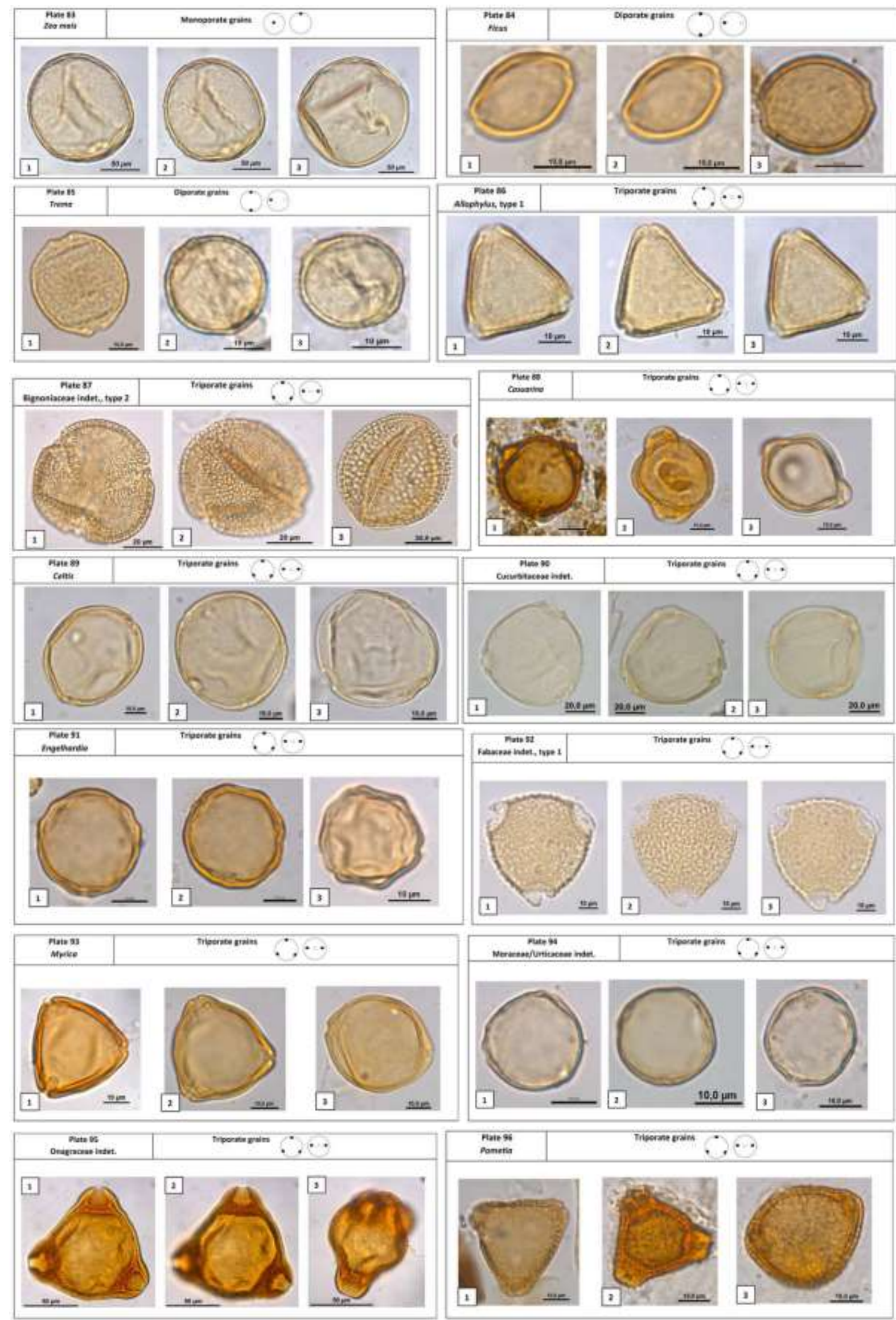

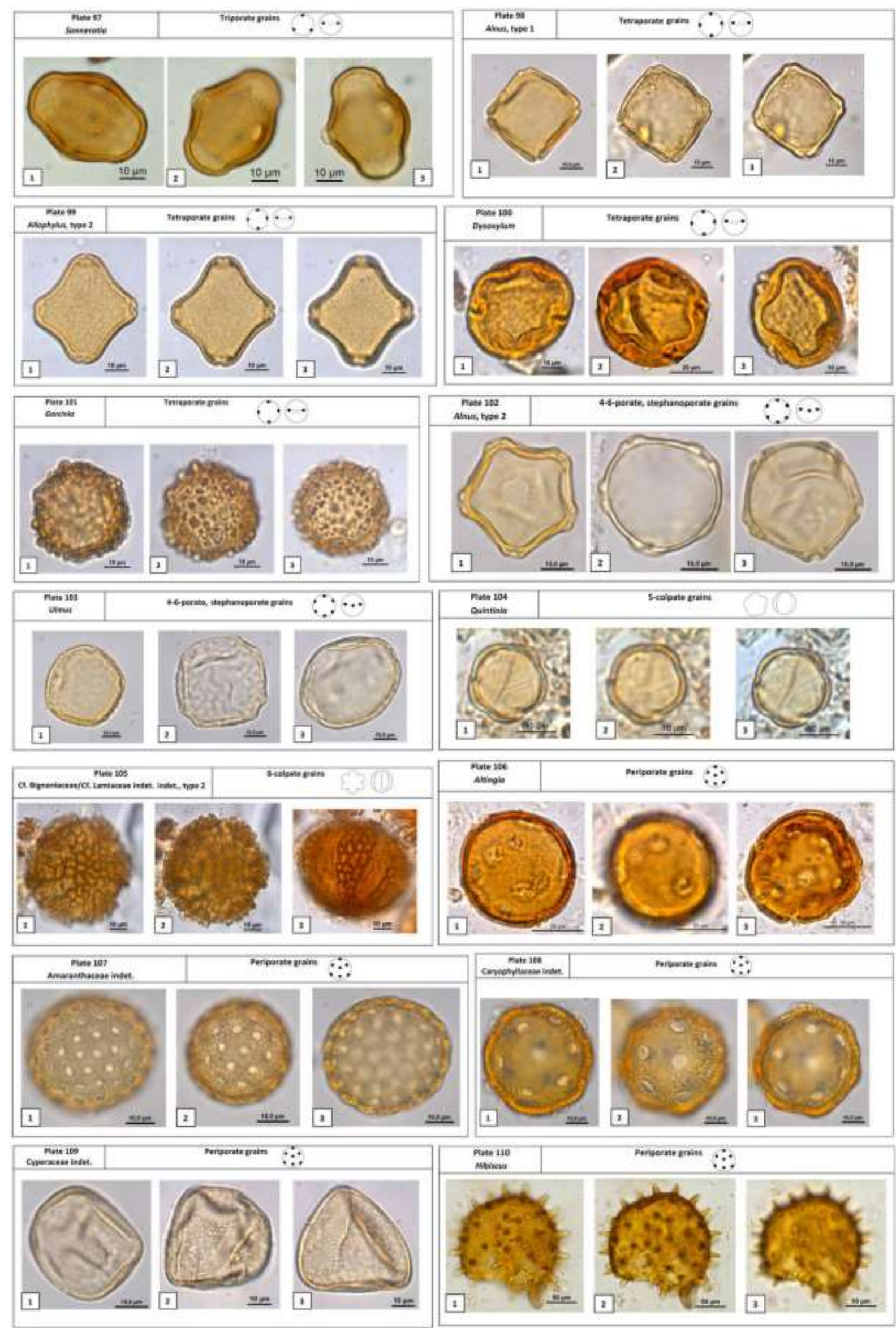

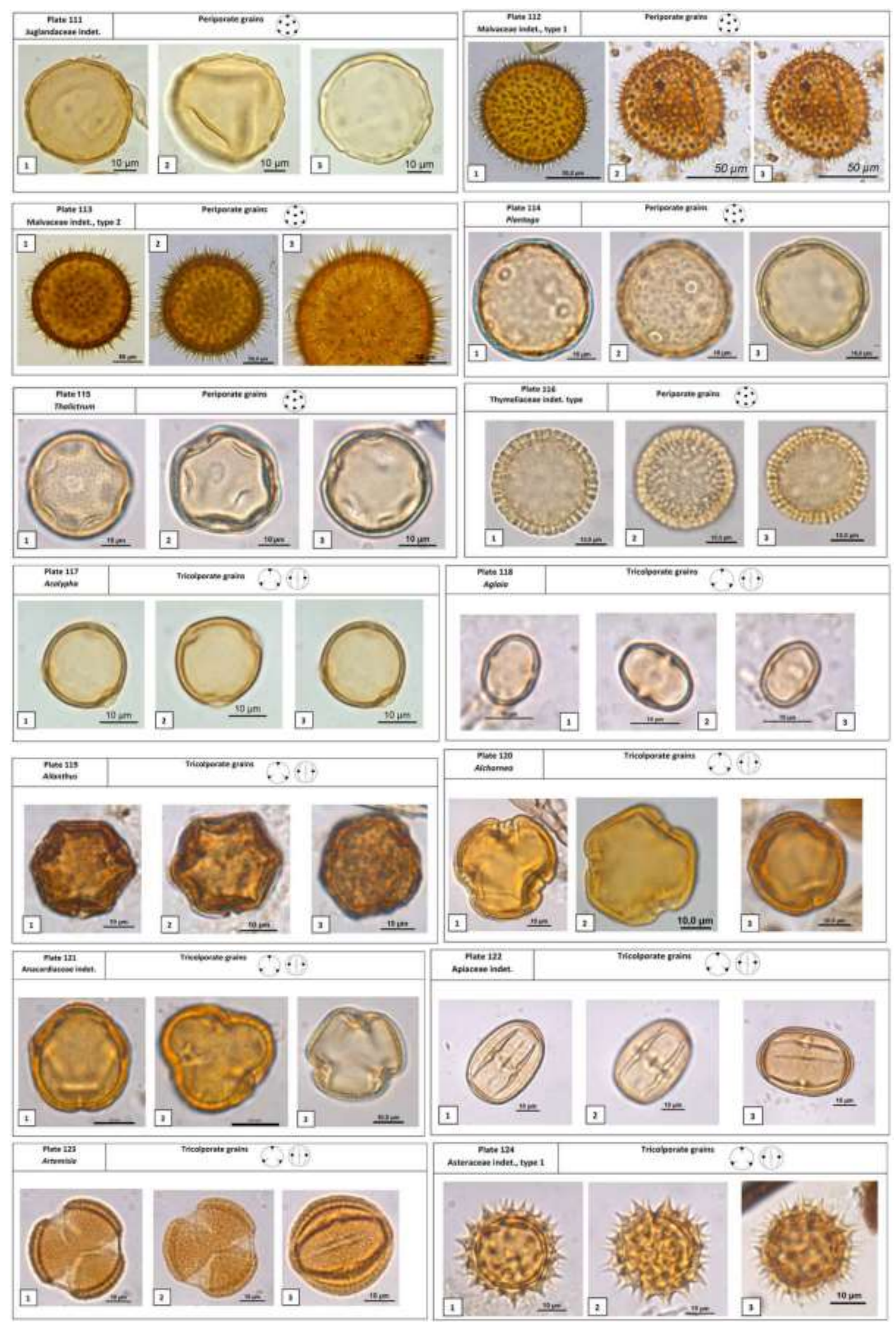


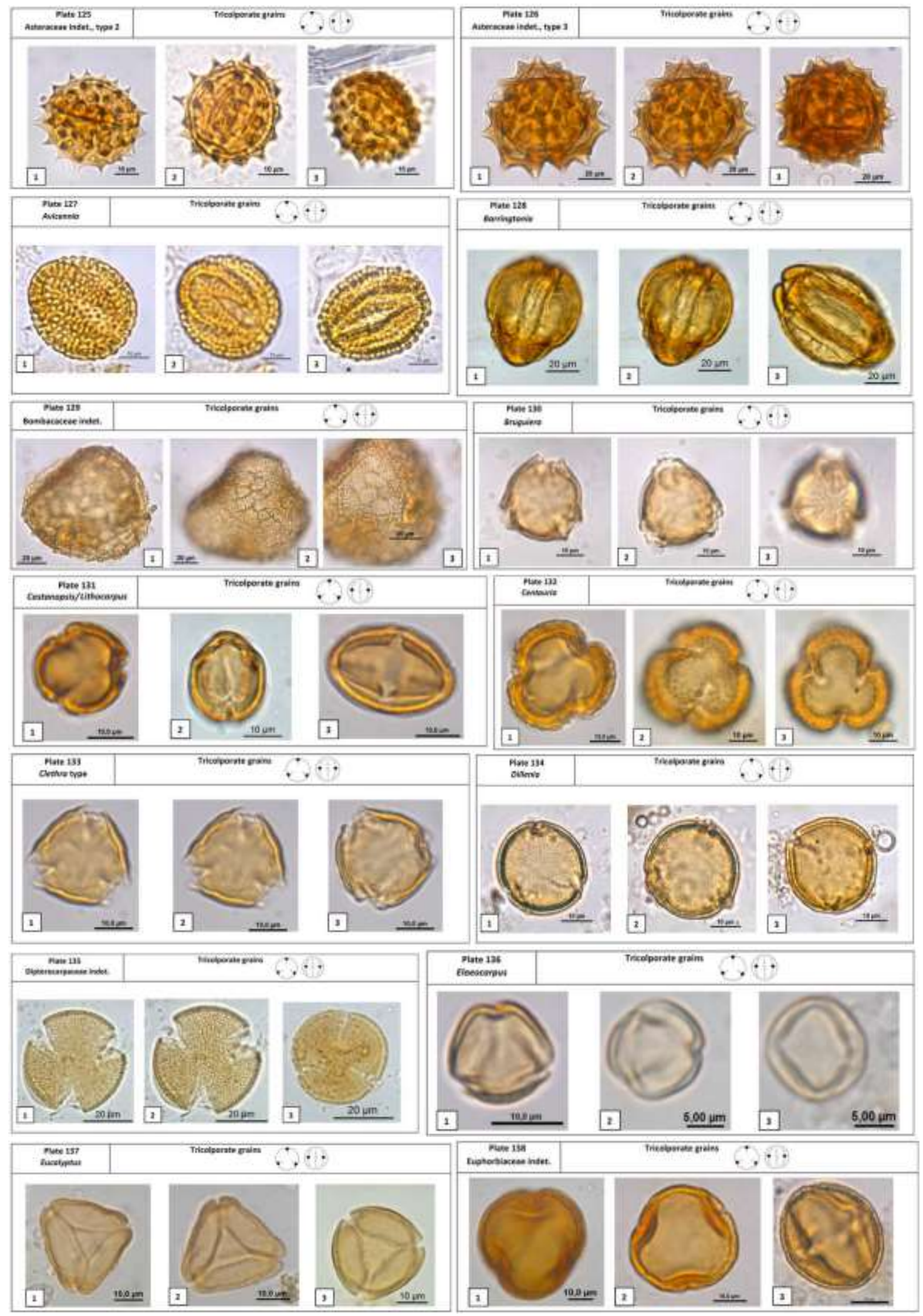



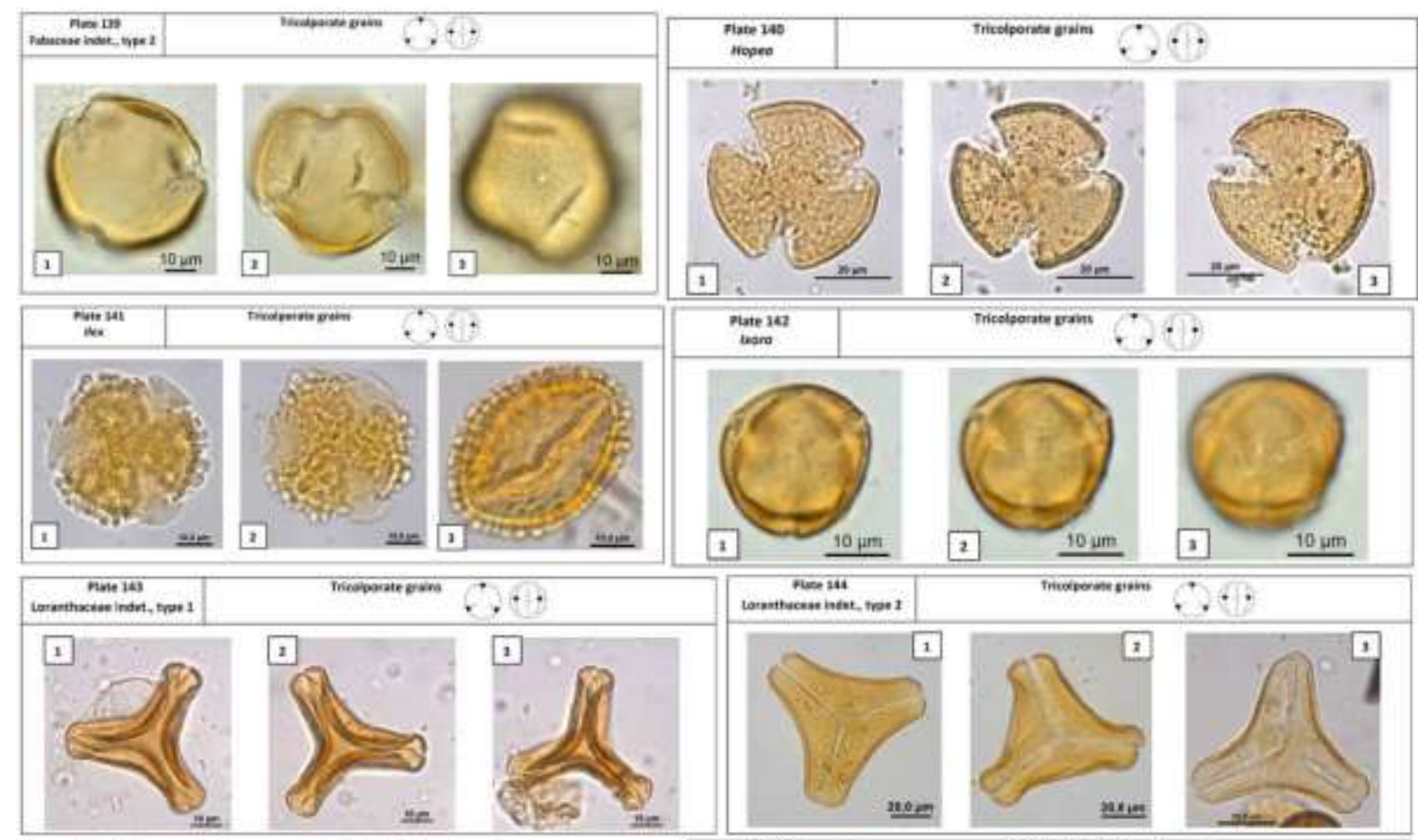

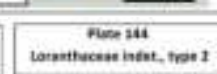

$2 \quad 10 \mu \mathrm{m} \quad 3 \quad 10 \mu \mathrm{m}$
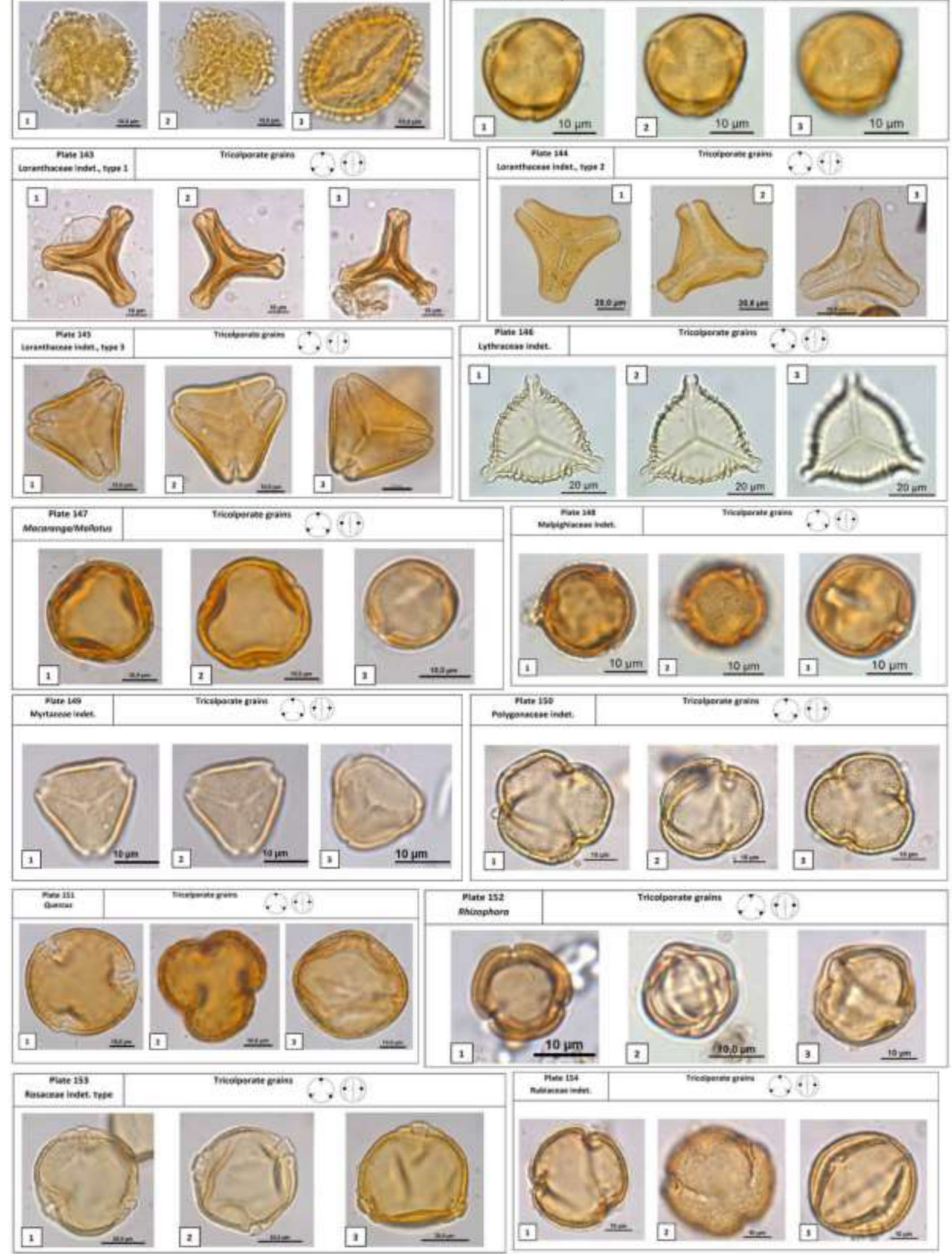

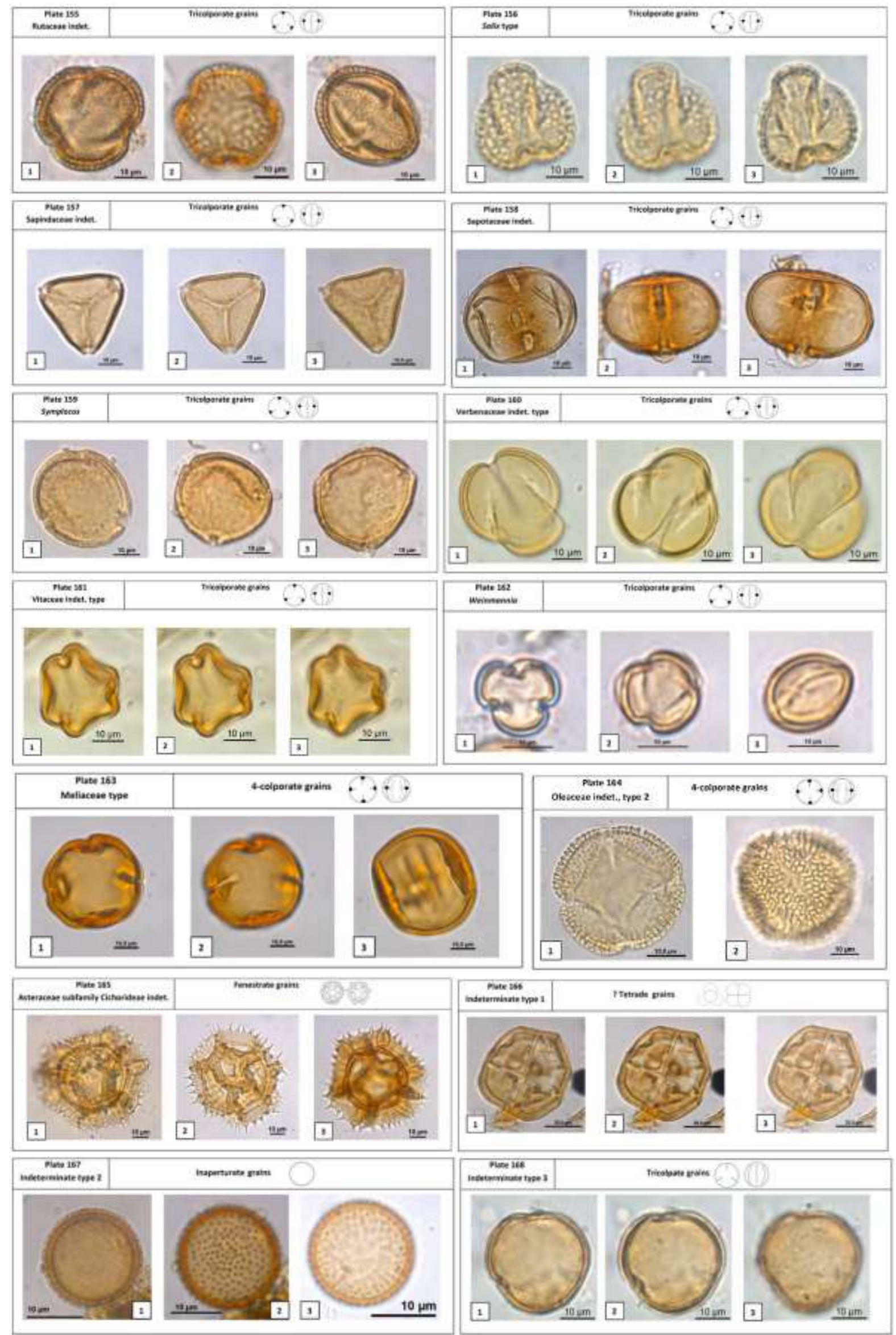

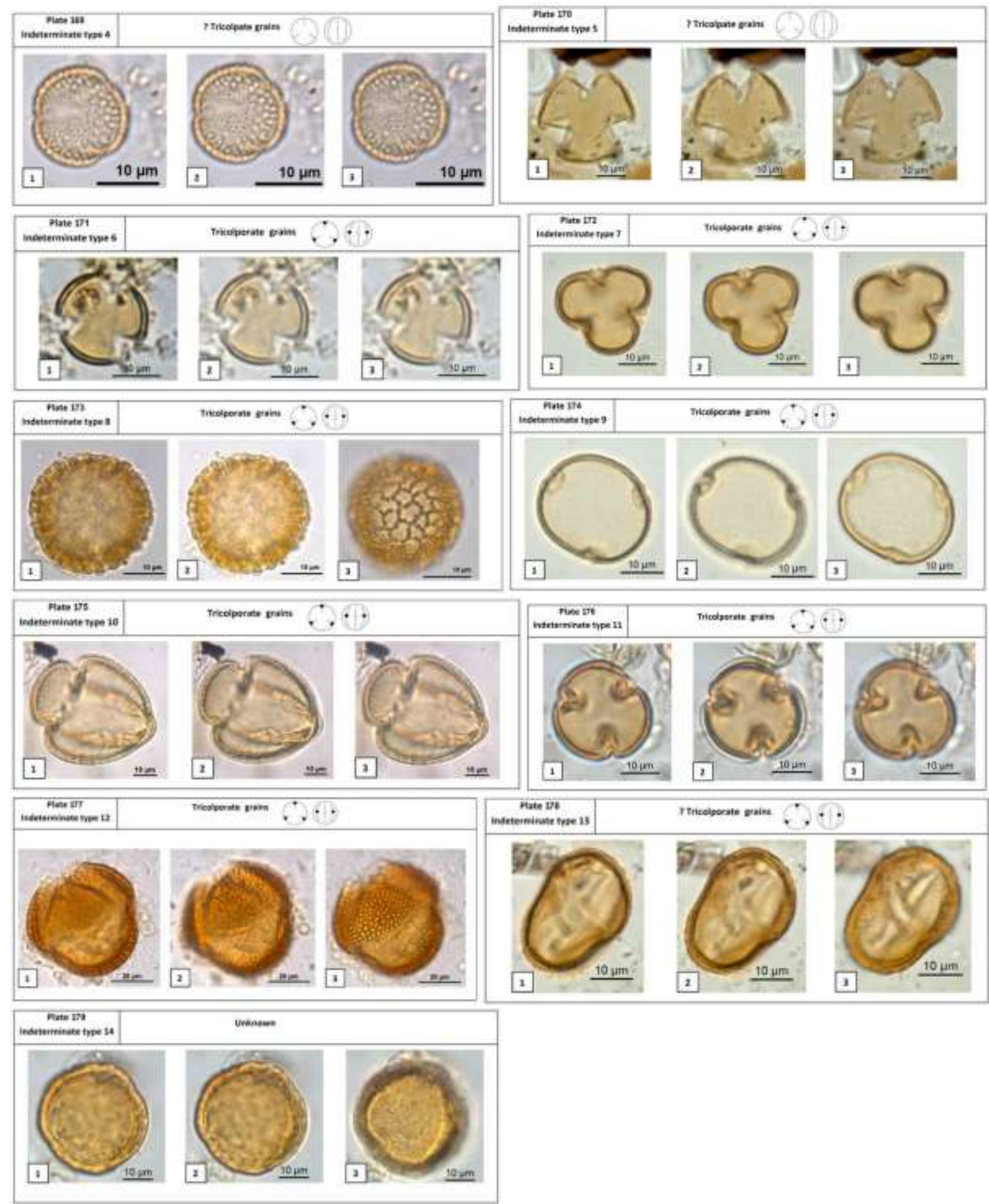


\section{Appendix B}

Complete list of organic-walled dinocysts types mentioned in the thesis

\begin{tabular}{|c|c|c|c|}
\hline name & core $1412-19$ & core $1609-30$ & core $1612-23$ \\
\hline Ataxodinum choanum & $*$ & & $*$ \\
\hline Bitectatodinium spongium & $*$ & $*$ & $*$ \\
\hline Bitectatodinium spongium & & & $*$ \\
\hline Brigantedinium spp. (Round Brown Cyst) & $*$ & $*$ & $*$ \\
\hline cyst of Polykrikos kofoidii & $*$ & $*$ & $*$ \\
\hline cyst of Polykrikos schwartzii & $*$ & $*$ & $*$ \\
\hline Dalella chathamensis & $*$ & & \\
\hline Echinidinium delicatus & $*$ & & \\
\hline Echinidinium granullatum & $*$ & $*$ & $*$ \\
\hline Echinidinium monospinum & $*$ & & \\
\hline Echinidinium transparantum & $*$ & $*$ & $*$ \\
\hline Echinidinium zonneveldiae & $*$ & $*$ & $*$ \\
\hline Impagidinium aculeatum & $*$ & & $*$ \\
\hline Impagidinium plicatum & & & $*$ \\
\hline Impagidinium sphaericum & & & $*$ \\
\hline Impagidinium ssp & $*$ & $*$ & \\
\hline Impagidinium strialatum & $*$ & & * \\
\hline Impagidinium variaseptum & $*$ & $*$ & \\
\hline Lejeunecysta oliva & $*$ & $*$ & $*$ \\
\hline Lejeunecysta paratenella & $*$ & & \\
\hline Lejeunecysta sabrina & * & & $*$ \\
\hline $\begin{array}{l}\text { Lingulodinium machaerophorum, normal } \\
\text { processies }\end{array}$ & $*$ & $*$ & $*$ \\
\hline $\begin{array}{l}\text { Lingulodinium machaerophorum, redusuced } \\
\text { processies }\end{array}$ & $*$ & $*$ & \\
\hline Nematosphaeropsis labyrinthus & $*$ & $*$ & $*$ \\
\hline Operculodinium centrocarpum & $*$ & $*$ & $*$ \\
\hline Operculodinium israelianum & $*$ & $*$ & $*$ \\
\hline Operculodinium spp & $*$ & $*$ & $*$ \\
\hline Cyst of Pentapharsodinium dalei & $*$ & $*$ & $*$ \\
\hline Polysphaeridium zoharyi & $*$ & $*$ & $*$ \\
\hline Quinquecuspis concreta & & & $*$ \\
\hline Selenopemphix nephroides & $*$ & $*$ & $*$ \\
\hline Selenopemphix quanta & $*$ & & $*$ \\
\hline Spiniferites elongatus type & $*$ & & \\
\hline Spiniferites mirabilis & $*$ & $*$ & $*$ \\
\hline Spiniferites pachydermus & $*$ & $*$ & $*$ \\
\hline
\end{tabular}




\begin{tabular}{|c|c|c|c|}
\hline Spiniferites ramosus & $*$ & $*$ & $*$ \\
\hline Spiniferites spp & $*$ & $*$ & $*$ \\
\hline Stelladinium robustum type & $*$ & & \\
\hline Stelladinium stellatum & $*$ & & \\
\hline Trinovantedinium applanatum & & & * \\
\hline Tuberculodinium vancampoae & $*$ & & $*$ \\
\hline Votadinium calvum & $*$ & $*$ & $*$ \\
\hline Votadinium spinosum & $*$ & $*$ & $*$ \\
\hline Xandarodinium xanthum & $*$ & $*$ & \\
\hline
\end{tabular}

Note: $\left({ }^{*}\right)$ indicates presence of the dinocyst type in the core material. Empty cell stays for abcence. 


\section{Appendix C}

\section{Complete Pollen Records}

Appendix C1. Complete pollen record (\%) of sediment trap JAM-2 showing percentages of pollen of mangroves, lowland and montane trees, herbs and fern spore as well as pollen and Pteridophyta sums and pollen accumulation rate (PAR) under changing monsoon conditions in the Indian Ocean off SW Java.

Appendix C2. Complete pollen record (\%) of the sequence 1412-19 showing relative frequencies of pollen and spore types, main vegetation groups, pollen and microcharcoal concentrations.

Appendix C3. Complete pollen record (\%) of the sequence 1609-30 showing relative frequencies of pollen and spore types, main vegetation groups, pollen and microcharcoal concentrations. 
Appendix C1. Complete pollen record (\%) of sediment trap JAM-2 showing percentages of pollen of mangroves, lowland and montane trees, herbs and fern spore as well as pollen and Pteridophyta sums and pollen accumulation rate (PAR) under changing monsoon conditions in the Indian Ocean off SW Java.

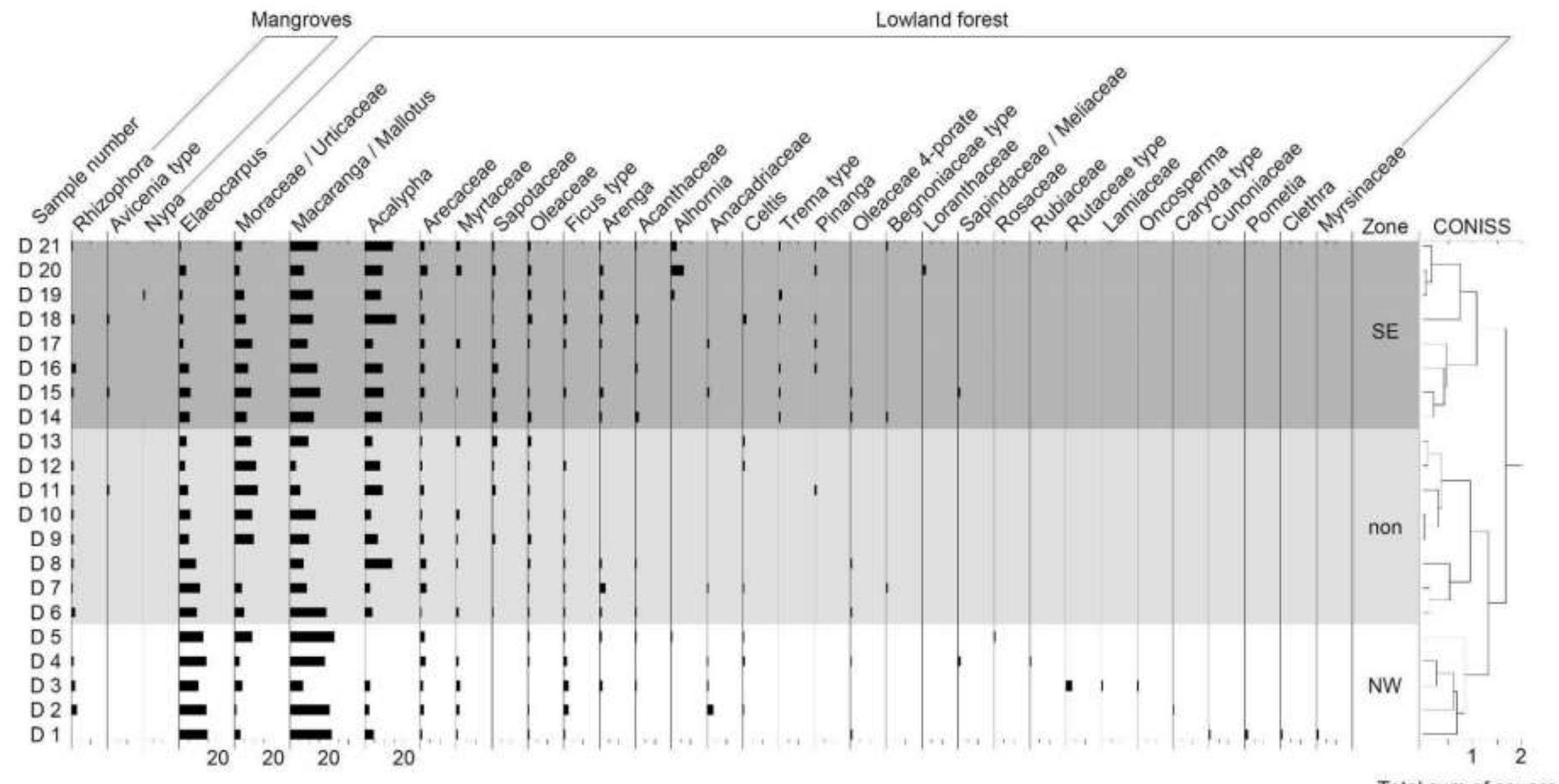

Notes: The abbreviations indicate the following: NW - northwest monsoon; non (light-grey shading) - intermonsoon period; SE (dark-grey shading), southeast monsoon; LDS - long distance component; $\mathrm{N}$ - long distance component collected during the northwest monsoon; $\mathrm{S}$ - long distance component collected during the southern monsoon. 
Appendix C1. Complete pollen record (\%) of sediment trap JAM-2 showing percentages of pollen of mangroves, lowland and montane trees, herbs and fern spore as well as pollen and Pteridophyta sums and pollen accumulation rate (PAR) under changing monsoon conditions in the Indian Ocean off SW Java (continuation).

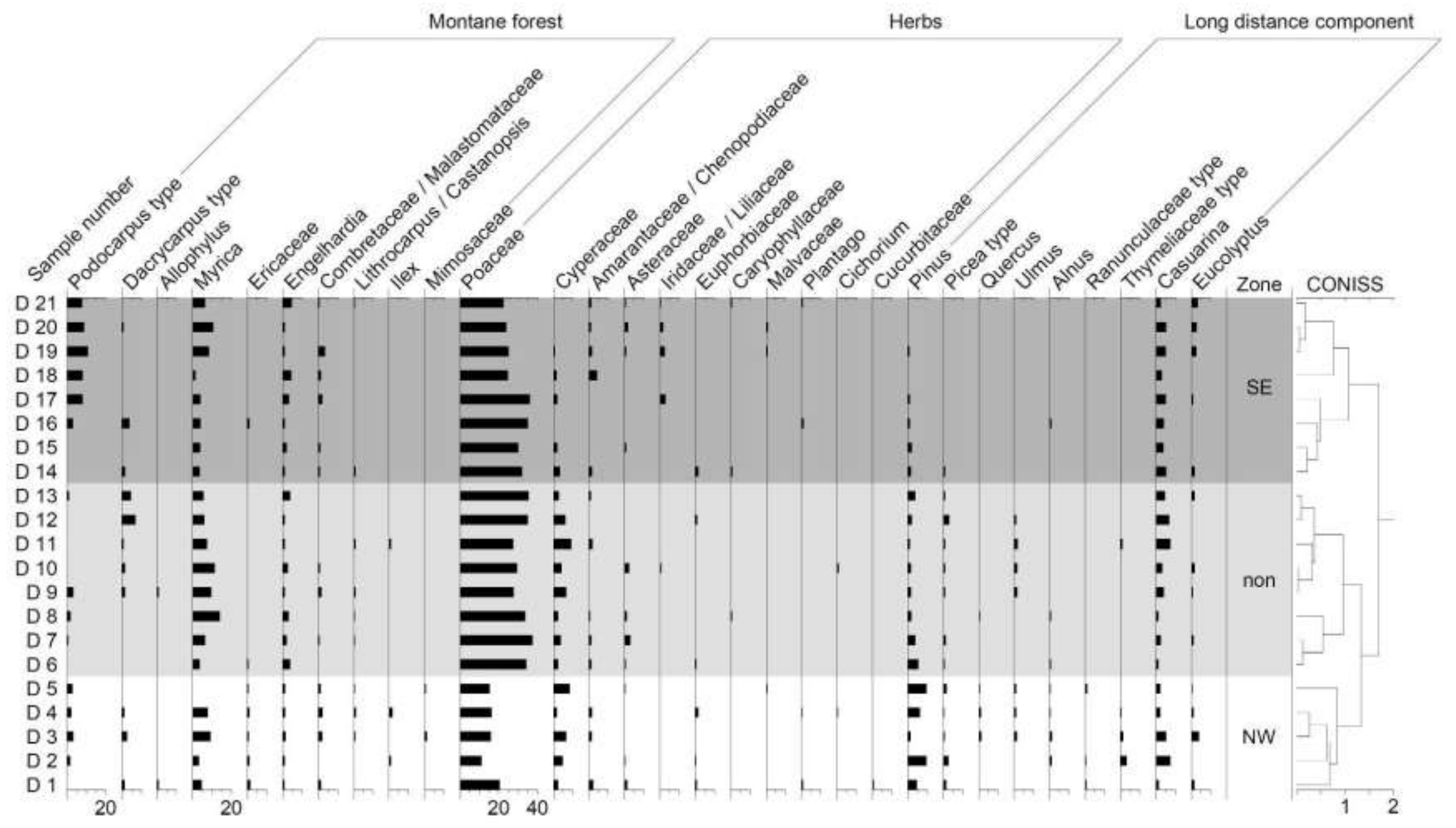

Total sum of squares

Notes: The abbreviations indicate the following: NW - northwest monsoon; non (light-grey shading) - intermonsoon period; SE (dark-grey shading), southeast monsoon; LDS - long distance component; $\mathrm{N}$ - long distance component collected during the northwest monsoon; $\mathrm{S}$ - long distance component collected during the southern monsoon. 
Appendix C1. Complete pollen record (\%) of sediment trap JAM-2 showing percentages of pollen of mangroves, lowland and montane trees, herbs and fern spore as well as pollen and Pteridophyta sums and pollen accumulation rate (PAR) under changing monsoon conditions in the Indian Ocean off SW Java (ending).

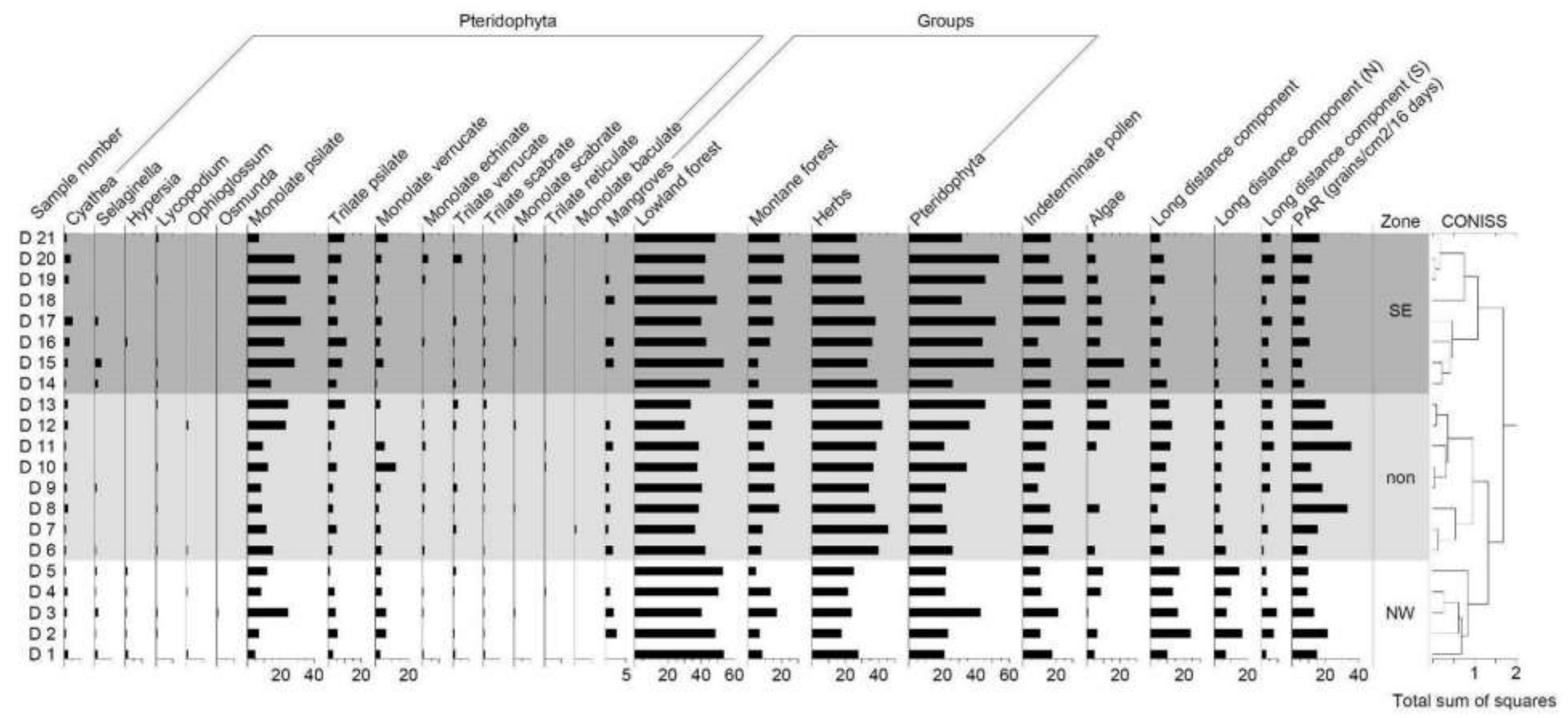

Notes: The abbreviations indicate the following: NW - northwest monsoon; non (light-grey shading) - intermonsoon period; SE (dark-grey shading), southeast monsoon; LDS - long distance component; $\mathrm{N}$ - long distance component collected during the northwest monsoon; $\mathrm{S}$ - long distance component collected during the southern monsoon. 
Appendix C2. Complete pollen record (\%) of the sequence 1412-19 showing relative frequencies of pollen and spore types, main vegetation groups, pollen and microcharcoal concentrations.

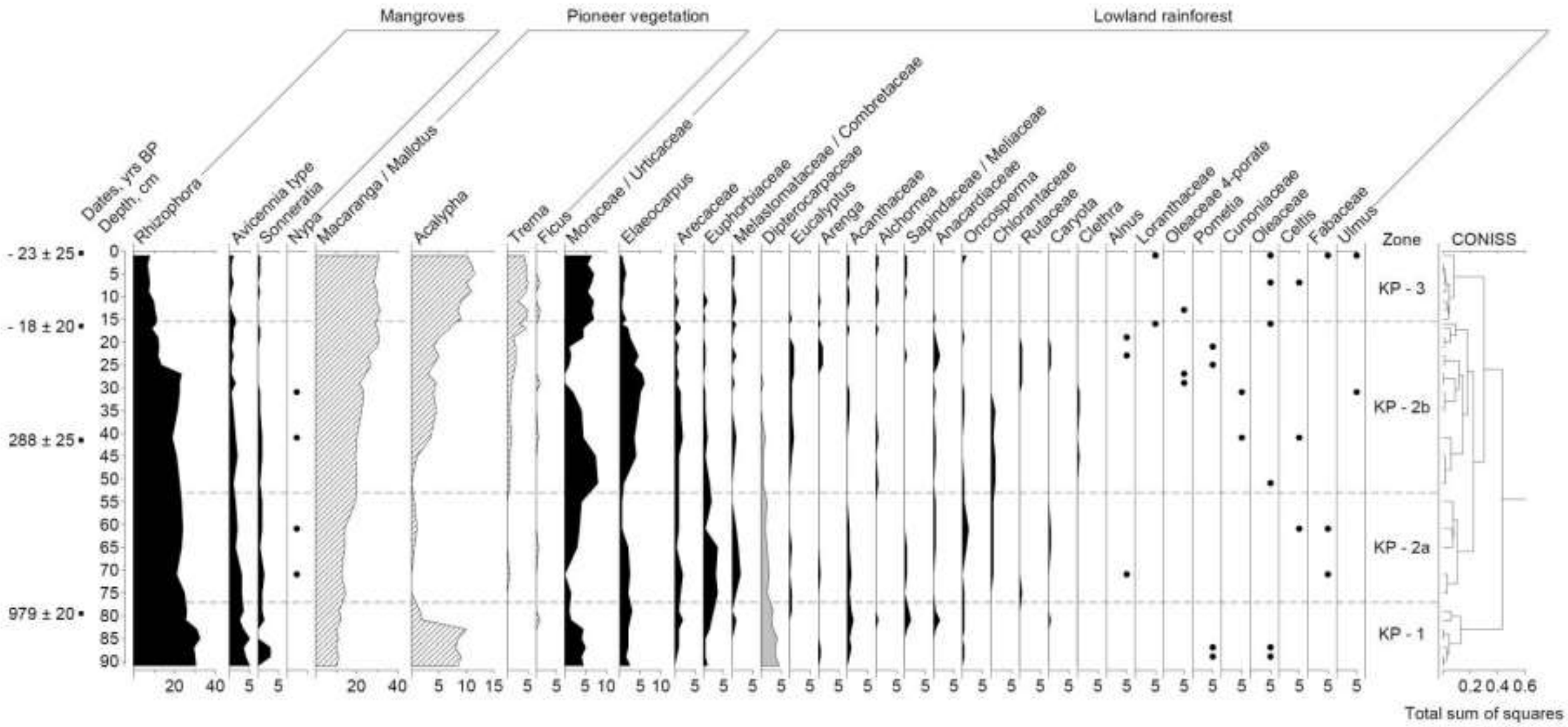

Note: Pollen types of pioneer taxa have striped profiles; pollen types of timber tree taxa have grey profiles. Presence of cysts types contributing to the dinocyst total sum less than $2 \%$ on average depicted as black dots. 
Appendix C2. Complete pollen record (\%) of the sequence 1412-19 showing relative frequencies of pollen and spore types, main vegetation groups, pollen and microcharcoal concentrations (continuation).

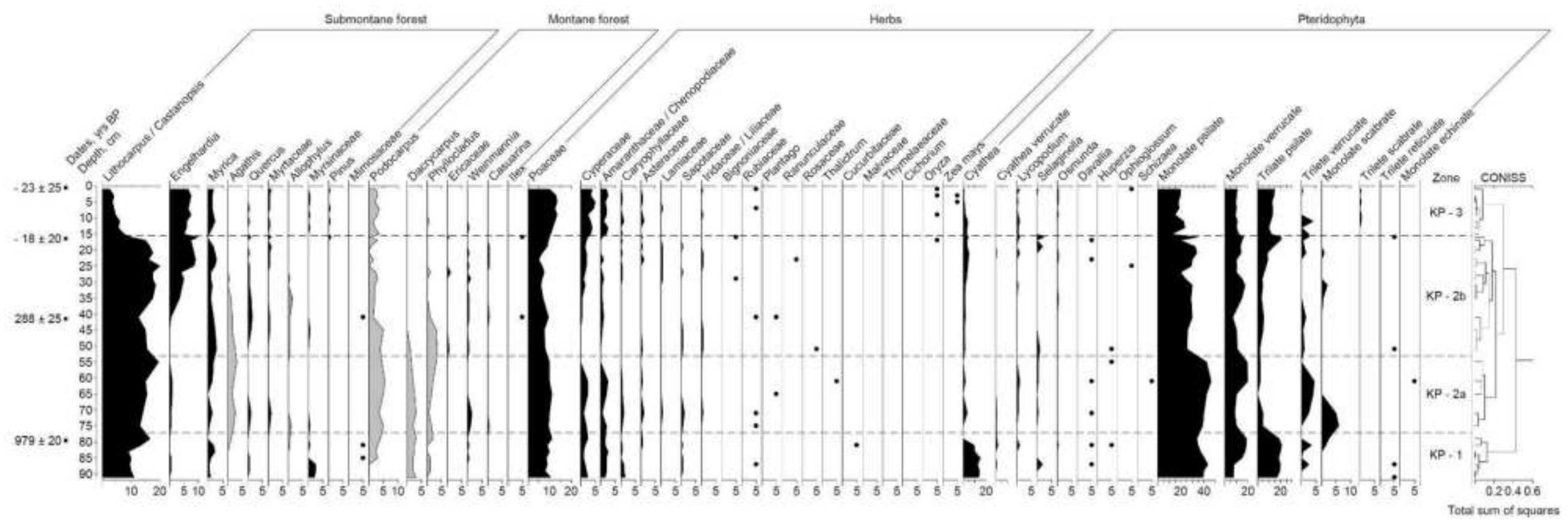

Note: Pollen types of pioneer taxa have striped profiles; pollen types of timber tree taxa have grey profiles. Presence of cysts types contributing to the dinocyst total sum less than $2 \%$ on average depicted as black dots. 
Appendix C2. Complete pollen record (\%) of the sequence 1412-19 showing relative frequencies of pollen and spore types, main vegetation groups, pollen and microcharcoal concentrations (ending).

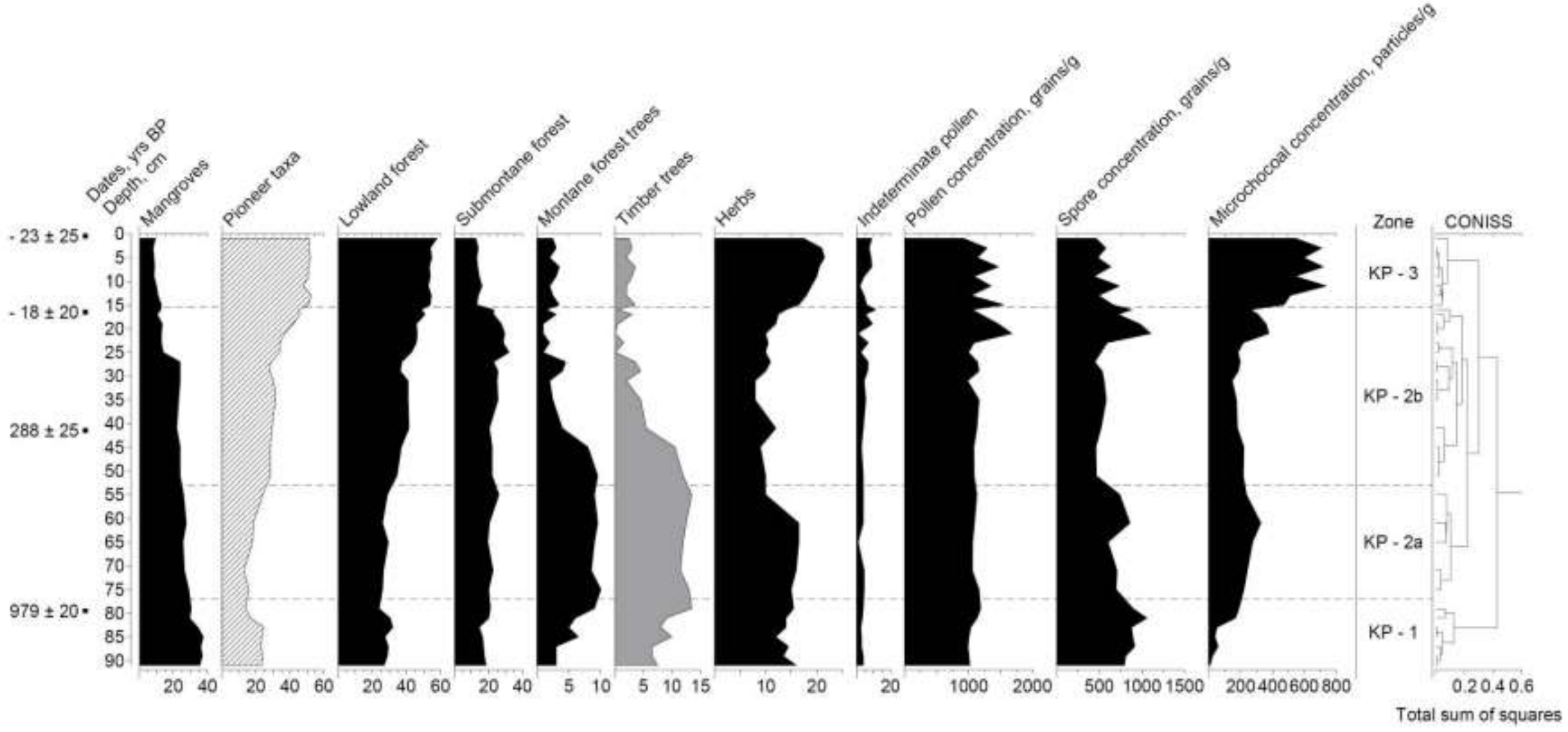

Note: Pollen types of pioneer taxa have striped profiles; pollen types of timber tree taxa have grey profiles. 
Appendix C3. Complete pollen record (\%) of the sequence 1609-30 showing relative frequencies of pollen and spore types, main vegetation groups, pollen and microcharcoal concentrations.

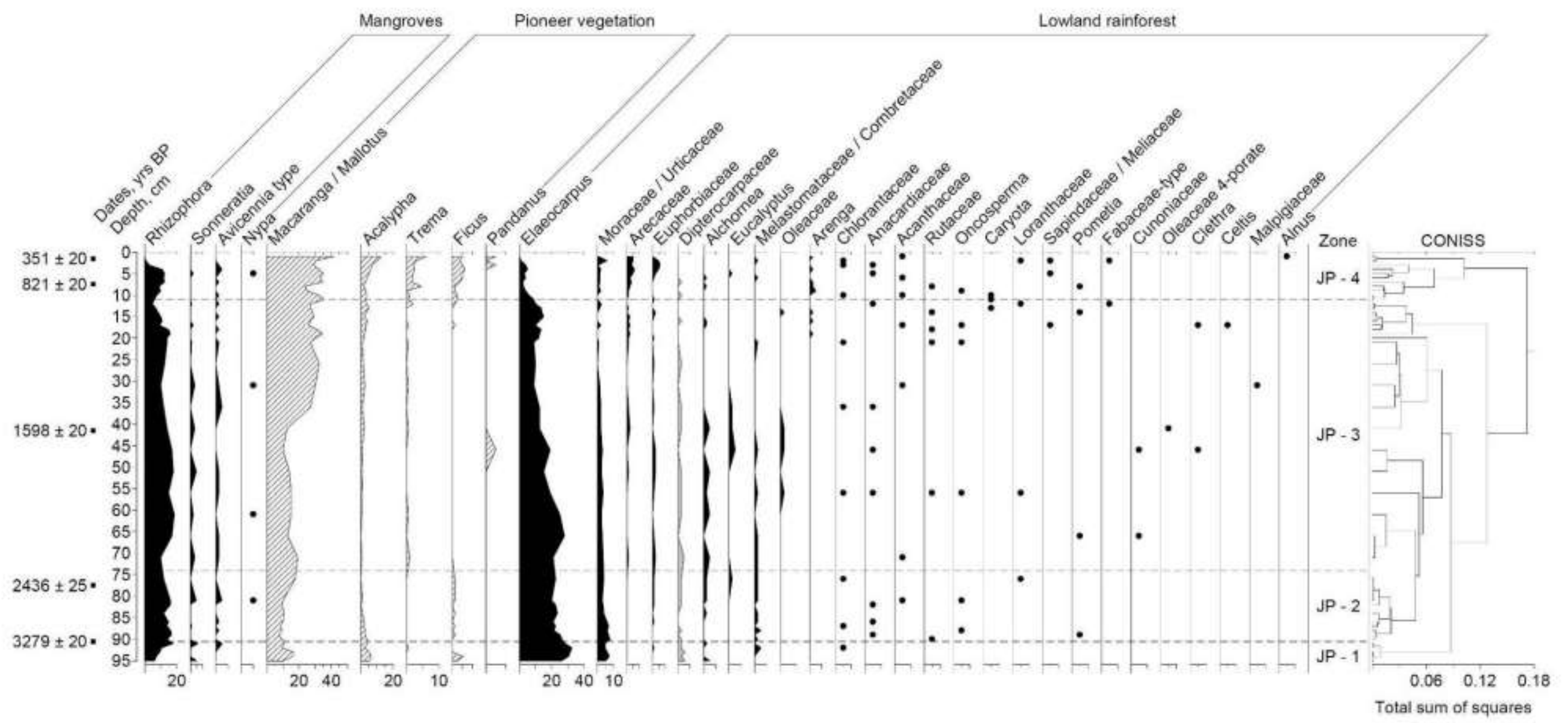

Note: Pollen types of pioneer taxa have striped profiles; pollen types of timber tree taxa have grey profiles. Presence of cysts types contributing to the dinocyst total sum less than $2 \%$ on average depicted as black dots. 
Appendix C3. Complete pollen record (\%) of the sequence 1609-30 showing relative frequencies of pollen and spore types, main vegetation groups, pollen and microcharcoal concentrations (continuation).

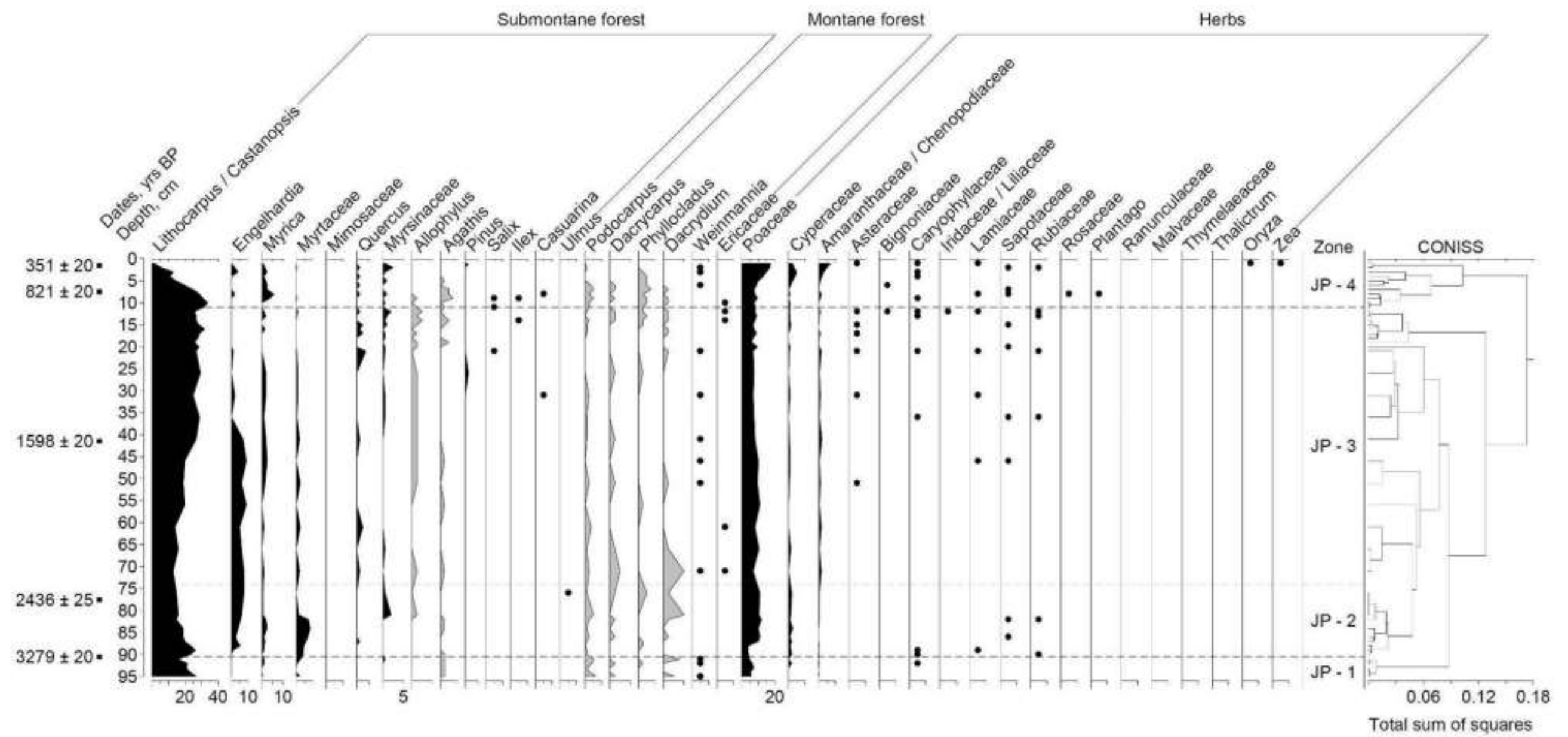

Note: Pollen types of pioneer taxa have striped profiles; pollen types of timber tree taxa have grey profiles. Presence of cysts types contributing to the dinocyst total sum less than $2 \%$ on average depicted as black dots. 


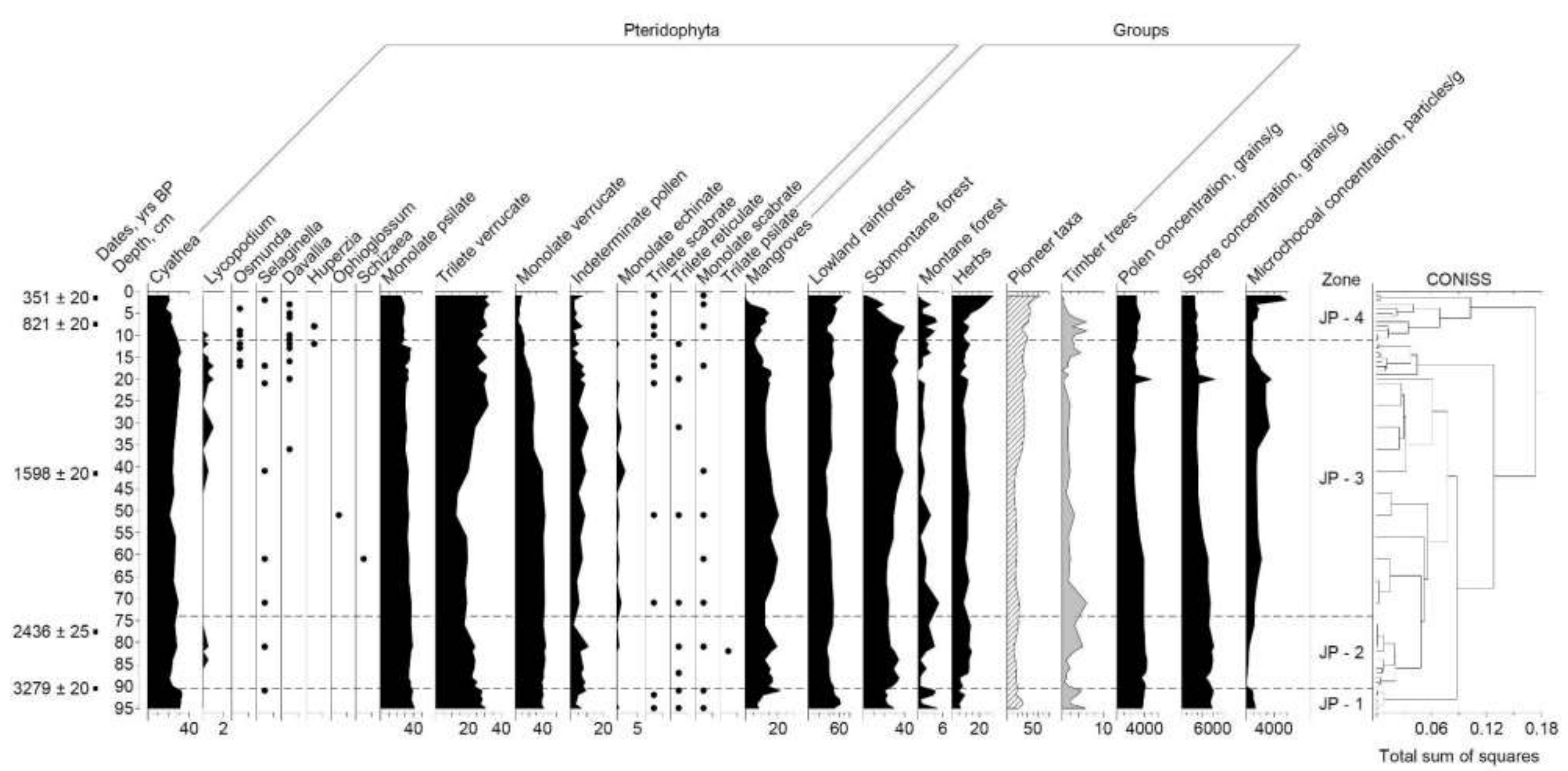

Note: Pollen types of pioneer taxa have striped profiles; pollen types of timber tree taxa have grey profiles.Presence of cysts types contributing to the dinocyst total sum less than $2 \%$ on average depicted as black dots. 


\section{Appendix D}

\section{Core Stratigraphy and Radiocarbon Dating}

Appendix D1. Stratigraphy of the core 1412-19 and calibrated age model (linear interpolation, cal yr BP vs core depth) based on the radiocarbon dates from Table 1 (Chapter 2) and the estimated sedimentation rate. The outlet at $71-72 \mathrm{~cm}$ is depicted as a point unconnected to other dating points.

Appendix D2. Stratigraphy of the core 1609-30 and calibrated age model (linear interpolation, cal yr BP vs core depth) based on the radiocarbon dates from Table 1 (Chapter 2) and the estimated sedimentation rate.

Appendix D3. Stratigraphy of the core 1612-23 and calibrated age model (linear interpolation, cal yr BP vs core depth) based on the radiocarbon dates from Table 1 (Chapter 4) and the estimated sedimentation rate. 

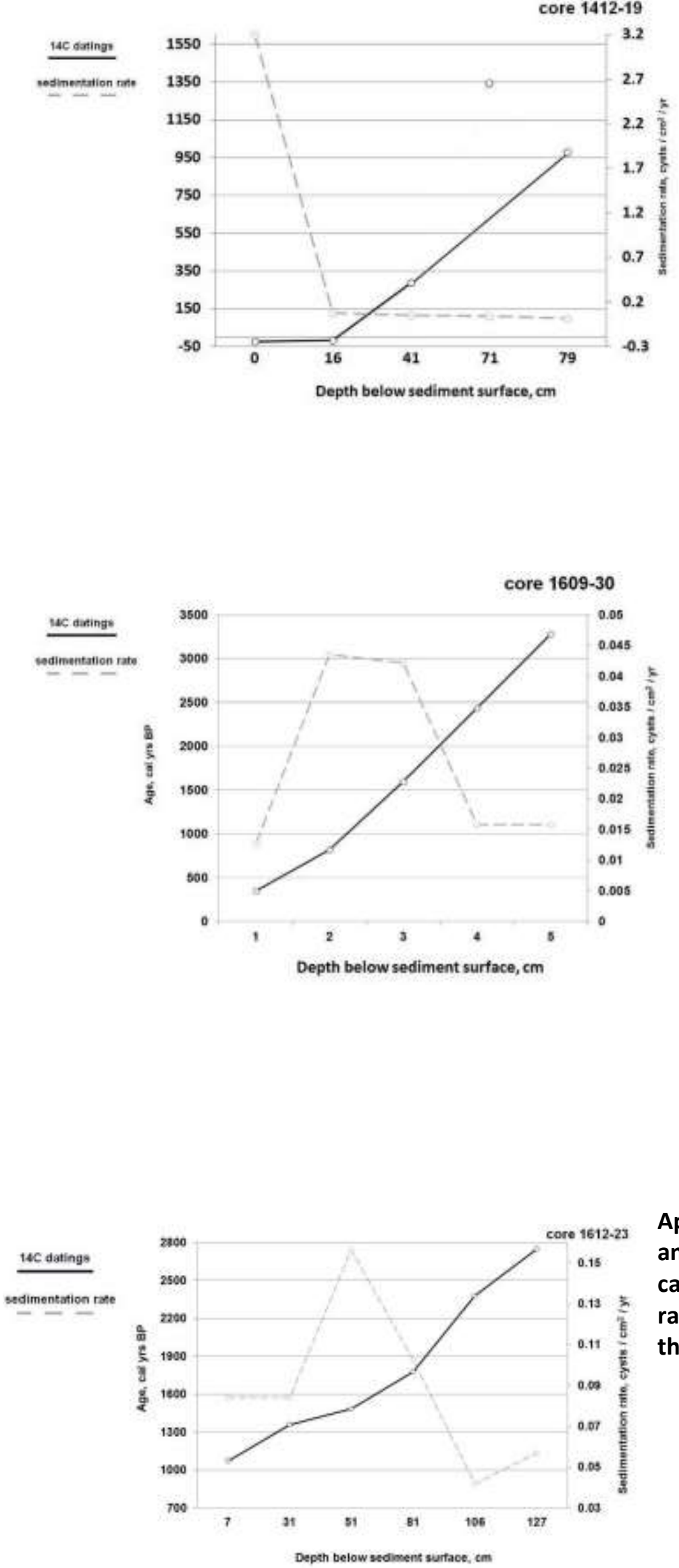

Appendix D1. Stratigraphy of the core 141219 and calibrated age model (linear interpolation, cal yr BP vs core depth) based on the radiocarbon dates from Table 1 (Chapter 2) and the estimated sedimentation rate. The outlet at $71-72 \mathrm{~cm}$ is depicted as a point unconnected to other dating points.
Appendix D2. Stratigraphy of the core 160930 and calibrated age model (linear interpolation, cal yr BP vs core depth) based on the radiocarbon dates from Table 1 (Chapter 2) and the estimated sedimentation rate.

Appendix D3. Stratigraphy of the core 1612-23 and calibrated age model (linear interpolation, cal yr BP vs core depth) based on the radiocarbon dates from Table 1 (Chapter 4 ) and the estimated sedimentation rate. 


\section{Declaration of originality and certificate of ownership}

I, Anastasia Poliakova, hereby declare that I am the author of the present dissertation entitled „The late Holocene history of vegetation, climate, fire dynamics and human impacts in Java and southern Kalimantan". All references and data sources that I used in the dissertation have been appropriately acknowledged and cited. I furthermore declare that this work has not and will be not submitted elsewhere in any form as part of another dissertation procedure. 